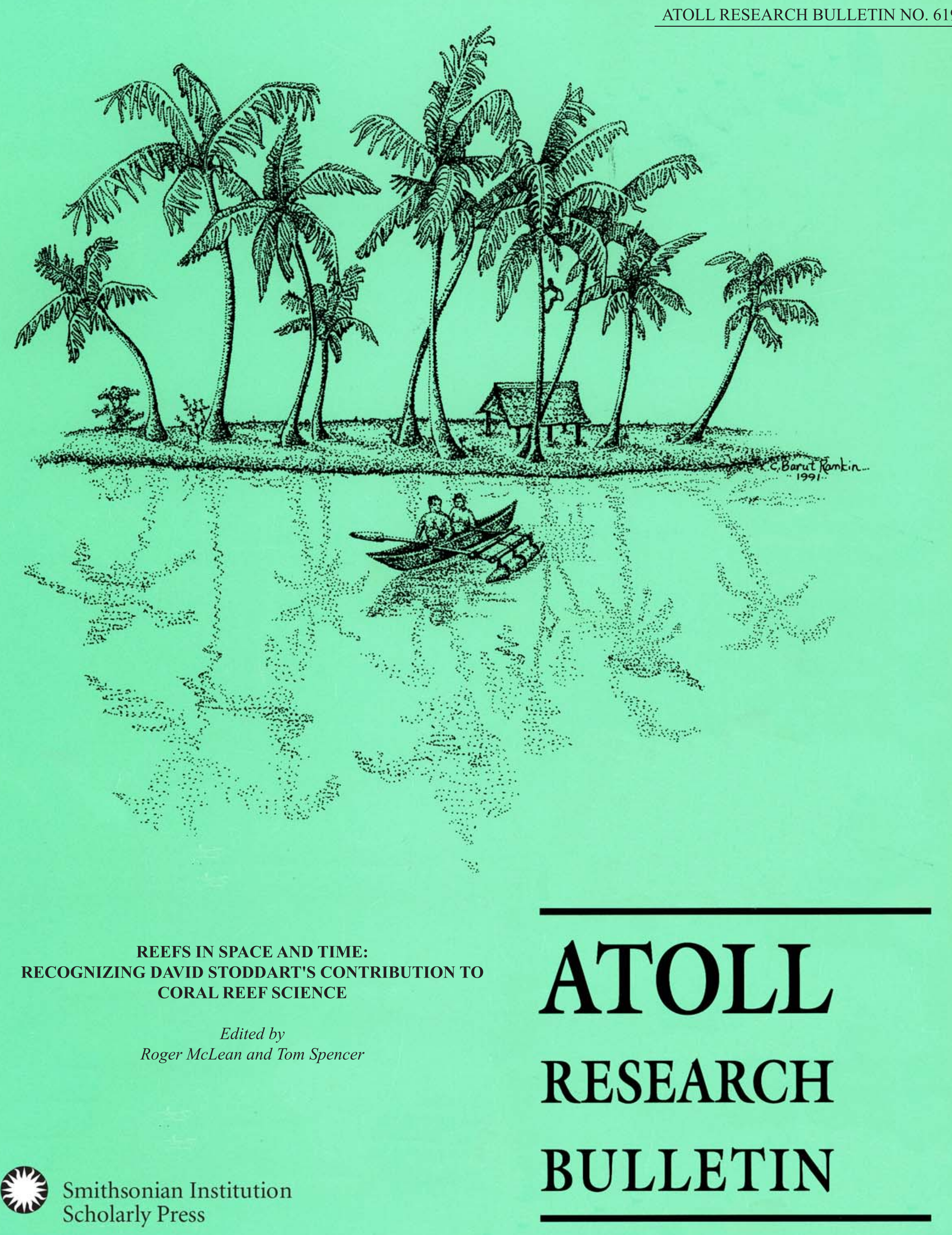




\section{REEFS IN SPACE AND TIME: RECOGNIZING DAVID STODDART'S CONTRIBUTION TO CORAL REEF SCIENCE}




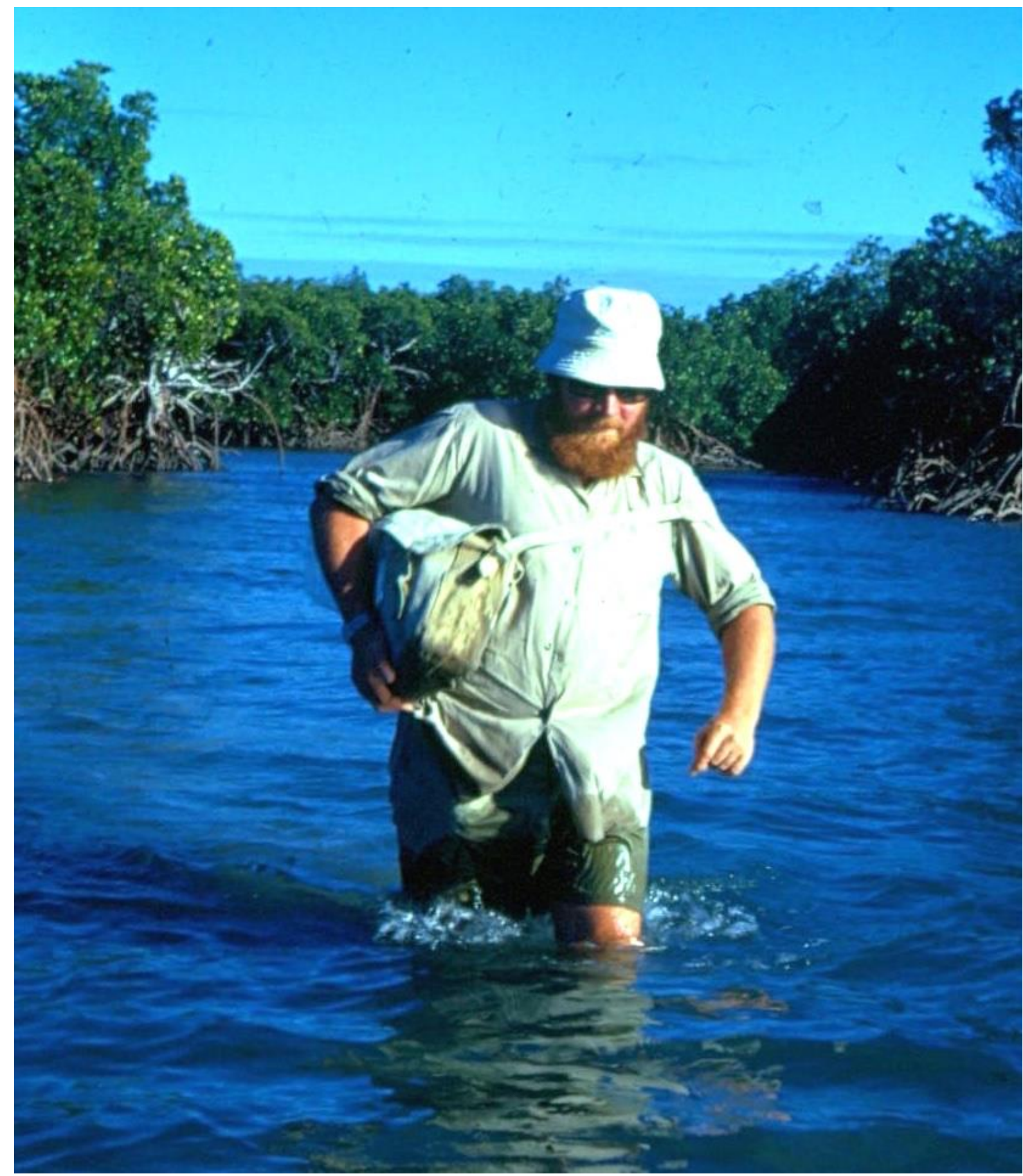

Frontispiece. 'Towards the end of a day in the field': David Stoddart returning to the Zodiac after a day's survey at Hampton Island in August 1973 during the Royal Society and Universities of Queensland Expedition to the northern Great Barrier Reef, Australia (Photo: Roger McLean). 


\title{
REEFS IN SPACE AND TIME: RECOGNIZING DAVID STODDART'S CONTRIBUTION TO CORAL REEF SCIENCE
}

\author{
Edited by \\ Roger McLean and Tom Spencer
}

Atoll Research Bulletin No. 619 19 September 2018

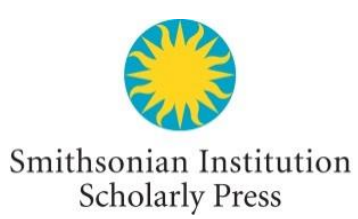

Washington, D.C. 
All statements made in papers published in the Atoll Research Bulletin are the sole responsibility of the authors and do not necessarily represent the views of the Smithsonian Institution or of the editors of the bulletin. Articles submitted for publication in the Atoll Research Bulletin should be original papers and must be made available by authors for open access publication. Manuscripts should be consistent with the "Author Formatting Guidelines for Publication in the Atoll Research Bulletin." All submissions to the bulletin are peer reviewed and, after revision, are evaluated prior to acceptance and publication through the publisher's open access portal, Open SI (https://opensi.si.edu).

Published by SMITHSONIAN INSTITUTION SCHOLARLY PRESS

P.O. Box 37012, MRC 957

Washington, D.C. $20013-7012$

https://scholarlypress.si.edu/

The rights to all text and images in this publication are owned either by the contributing authors or by third parties. Fair use of materials is permitted for personal, educational, or noncommercial purposes. Users must cite author and source of content, must not alter or modify the content, and must comply with all other terms or restrictions that may be applicable. Users are responsible for securing permission from a rights holder for any other use.

ISSN: 0077-5630 (online) 
FOREWORD vii

Ian Macintyre

PREFACE

ix

Roger Mclean and Tom Spencer

DAVID STODDART'S WRITINGS ON CORAL REEFS, 1960-2008

'So many expeditions, so many projects, so many papers, so much laughter'

Tom Spencer

MARINE RESEARCH IN THE BELIZE ATOLLS, GLOVERS REEF,

Eberhard Gischler

MAPPING THE LAGOON AT ALDABRA ATOLL, WESTERN INDIAN OCEAN

Sarah Hamylton, Annelise Hagan, Nancy Bunbury,

Frauke Fleischer-Dogley, and Tom Spencer

THE STODDART EXPEDITION TO THE NORTHERN GREAT BARRIER

REEF 1973: A VOYAGE OF DISCOVERY

J. E. N. Veron

UNDERSTANDING THE REASONS FOR THE REORIENTATION OF

HERON ISLAND, A CORAL SAND CAY, GREAT BARRIER REEF, AUSTRALIA

Peter G. Flood

HOLOCENE SEA LEVELS ON THE GREAT BARRIER REEF:

REFLECTIONS ON FOUR DECADES OF DEBATE AND THE

LEGACY OF THE 1973 EXPEDITION TO THE NORTHERN

GREAT BARRIER REEF

Scott Smithers, David Hopley and Roger Mclean

A GEOGRAPHICAL INVESTIGATION OF FACTORS AFFECTING

THE NUMBER OF PLANTS ON NORTHERN AND SOUTHERN

SAND CAYS OF THE GREAT BARRIER REEF, AUSTRALIA

Sarah M. Hamylton

MANGROVES AND CORAL REEFS: DAVID STODDART 
David R. Stoddart and Francis J. Murphy

ALEXANDER AGASSIZ AND CORAL REEF CONTROVERSY: INTRODUCTORY NOTE

David Dobbs 


\title{
CORAL REEFS IN SPACE AND TIME: RECOGNITION OF DAVID STODDART'S CONTRIBUTION TO CORAL REEF SCIENCE
}

\author{
Edited by ROGER MCLEAN and TOM SPENCER
}

\section{FOREWORD}

A memorial ARB volume dedicated to David Stoddart, indefatigable atoll and coral reef scientist, is long overdue. His contribution of more than 40 papers to the Bulletin alone since the 1960s needs to be remembered along with his other numerous publications and fieldwork in reefs of the Pacific and Indian Oceans and off Belize. He was also an early avid supporter of the Bulletin, recognizing its great value in providing a much-needed platform for the "nitty-gritty" details of reef research.

Even after serious health issues began plaguing David in later life, his commitment to reef science remained unflagging. He still managed to travel to various outposts, as I well remember when David and three other "Cambridge boys" (Paul Bregazzi, John Thorpe, and Will Warham) reunited on a highly memorable field trip to Belize in 2002 - David now accompanied by a walking stick, but as articulate, determined to continue working in the field, and humorous as ever. I felt honored to be present at that reunion.

Being a close colleague and friend of David's was an experience like no other. His knowledge of the world's reefs and their geography was encyclopedic and never failed to bowl me over in the forty some years that I knew him. It is no wonder that he is recognized as one of the leading figures in coralreef science, not to mention reef conservation. He set a high standard for detailed field surveys of reef topography and biogeography that made me think of him as a classical explorer, resolutely leading expeditions of specialists in various disciplines, carefully documenting his findings, and often communicating them early in long, eloquent, and enthusiastic letters to his colleagues.

As I can also attest, David's dedication to reef studies was seminal in the founding of the international journal Coral Reefs and the International Coral Reef Symposium, both of which are now widely respected venues for the dissemination of information on reef research. He was the obvious choice for first president of the International Society for Reef Studies and the first recipient of its Darwin Medal in recognition of his contributions to reef science.

On a personal level, all who knew David would agree that any meeting with him was bound to be filled with raucous laughter. Once at a dinner following a scientific meeting in Hawaii, where guests were served a variety of local fare, including poi, I found myself struggling to get through this particular dish. Not wanting to embarrass myself, I secreted my bowl under a lush table centerpiece-but my relief was short-lived. A roar of laughter across the table alerted everyone to the ploy. It was David's unmistakable baritone, bellowing: "I say, Macintyre, I think you have misplaced your poi."

The last time I saw David was during his trip to Washington a few years before his death. Undaunted by torrential rain and his declining health, he made a special effort to drive over (with his wife June behind the wheel, as always) to see me at home. It was a wonderful final meeting, with David in fine form discussing the good old days filled with grand adventures, as well as the scientific questions that still needed to be addressed. I was touched that he and June felt it important enough to visit on that stormy night — and delighted to see that he was still the same person I had long admired, undeterred by life's challenges.

Ian Macintyre

September 2017 



\section{PREFACE}

This volume of papers grew out of out of the first session on the first day of the $13^{\text {th }}$ International Coral Reef Symposium (ICRS) held in Honolulu, Hawaii in June 2016. Participants at the session agreed, rather than submitting manuscripts to the symposium proceedings, to provide papers for a special issue of the Atoll Research Bulletin. This to recognize the contributions of David Stoddart (1937-2014) to coral reef science. In his personal memoir, in the 'Golden Issue (1951-2001)' of the Atoll Research Bulletin, Stoddart recounted some of his 'salient moments on coral reefs around the world and in the emergence of coral reef science as a discipline' (Stoddart, 2001: 235). The ICRS -16 session titled 'Modern reefs and reef islands: reflections and resonance of David Stoddart's contributions to coral reef science' was organized by Roger McLean, Tom Spencer and Barbara Brown to consider some of those 'salient moments' and to reflect on his pioneering contribution to coral reef science in both personal and general terms. It was also an opportunity to assess the long-term resonance of his coral reef and reef island research.

Formal presentations at the session included: a review of modern and historic approaches to mapping coral reef environments (Hagan, Hamylton and Spencer); the scientific legacy of the 1973 expedition to the northern Great Barrier Reef (McLean); an assessment of microatolls as indicators of sea level change on reefs (Woodroffe); a reconsideration of Darwin's Bermuda paradox (Rosen and Darrell); and the utility of Stoddart's early 1960s research on the Belize atolls as a baseline for assessing environmental and habitat change. This baseline continues to be used by undergraduate students from Wake Forest University on annual field surveys to the Belize atolls (Perlman, Tietbohl, Ashley-Ross and Silman). However, the session opened with a summary of David Stoddart's seminal 66 page review of the 'Ecology and Morphology of Recent Coral Reefs' (Stoddart, 1969) published just five years after he had finished his $\mathrm{PhD}$ on the reef islands of three Belize atolls. That presentation (Spencer and Brown) closed with a quotation from the Stoddart $(1969$, p. 480) review: 'central to any discussion of the relationship between ecology and morphology of coral reefs must be consideration of the time and space scales involved...' It is that quotation we believe is apposite as the title for the present collection of papers, though we have reversed the 'scale' order to give precedence to the geographical dimension (space) over the historical dimension (time). In so doing we recognize Stoddart's longstanding belief in the value of comparative investigations - a methodology which he traced back to Reinhold Forster, naturalist on the second of Cook's Pacific voyages - and his often repeated call to 'make it comparative' (Stoddart, 2001: 246).

In many ways the present volume of papers is representative of that belief. The papers are arranged in a sequence that reflects the major phases of Stoddart's field activity by recognizing his "work over the years in the Caribbean (first) the Indian Ocean (second) and the Pacific (third)" (Stoddart 2001, 270-271) from British Honduras (Belize) in the early 1960s through French Polynesia in the 1990s. But before embarking on this sequence it is important to get an overview of David Stoddart's writings on coral reefs. This is done in the first paper, a summary of David Stoddart's five decades of writings on coral reefs including a comprehensive bibliography of those writings. Appropriately this has been compiled by one of Stoddart's former PhD students, Tom Spencer (this issue p. 1-17). Tracing this record has been a painstaking task but the results, summarized graphically and in maps, clearly demonstrate the immense breadth and depth of Stoddart's reefal scholarship. Spencer also demonstrates the magnitude and frequency of Stoddart's contributions to the Atoll Research Bulletin covering all reef provinces and reef and island habitats, processes and themes concluding that "it is entirely fitting that Stoddart's coral reef bibliography should be published in the Atoll Research Bulletin ..." (Spencer, this issue p.4).

Spencer also notes there were two locations where Stoddart had a constant interest: Belize on the Atlantic coast of Central America; and Aldabra in the western Indian Ocean. Contributions on both of these locations are included in this volume, first with a paper by Eberhard Gischler on the atolls of Belize followed by one on the lagoon of Aldabra by Sarah Hamylton, Annelise Hagan, Nancy Bunbury, Frauke Fleischer-Dogley and Tom Spencer. 
In the late 1950s and early 1960s Belize, at the time the British colony of British Honduras, was 'a country then virtually unknown except archeologically' and it was 'a case of pure serendipity' that Stoddart began his coral reef research there. He admits that when he arrived in Belize "it was at once apparent that I knew next to nothing about the coral reefs and reef islands that were to become the focus of my life." (Stoddart 2001, p. 242). But after a few years he acknowledges: "At the end of it, I felt I had some understanding of the reefs and reef islands of British Honduras; chipping away to my ignorance at last I knew something of the reef animals and the island plants" (Stoddart, 2001, p. 245). That 'understanding' is warmly praised by Eberhard Gischler (this issue p. 19-44) who reviews marine research in the Belize atolls since the pioneering work of David Stoddart noting that these were not Darwinian atolls but part of a massive 'carbonate platform'. In a personal note Gischler refers to a discussion with David Stoddart in 2008 "and we talked about the Maldives, where I had started a project and where he had worked also in the 1960s. But we eventually came back to the Belize atolls where both his and my work on modern coral reefs had begun with doctoral and habilitation theses, respectively". Gischler concludes his review by acknowledging that "An enormous body of data has accumulated based on research on the Belize atolls since the late 1950s and early 1960s" to which we can add that a not inconsequential number publications (collectively $>50$ ) to that 'body of data' have been contributed by both Stoddart and Gischler.

David Stoddart gained his PhD in 1964 and became a member of staff of the Department of Geography at Cambridge University. In his autobiography he rhetorically asks: "So where to proceed from the work in Belize?" (Stoddart, 2001, p. 246). He answers 'make it comparative' which meant the Indian Ocean (Addu Atoll in the Maldives in 1964) and the Pacific (the British Solomon Islands in mid1965). Then in 1966 he returned to the Indian Ocean in another serendipitous field trip, this time to the second island in which he had an abiding interest, Aldabra "one of the most remarkable islands on earth"' (Stoddart, 2001, p. 249). Ultimately Aldabra became a World Heritage site, and in their paper on the benthic communities and bathymetry of the lagoon at Aldabra, Hamylton, et al. (this issue p. 45-59) note that the World Heritage conservation designation was due largely to the scientific advocacy and campaigning work of David Stoddart, with his strong focus on creating detailed and accurate inventories of the atoll's biological and physical attributes. The lagoon mapping exercise described by Hamylton et al. uses GPS and a drop camera from a small dinghy at 486 locations within the lagoon to provide a detailed snapshot of the habitats and bottom topography of the lagoon that had hitherto been unavailable to physical and ecological science.

After Aldabra Stoddart (2001, p. 253) reckoned "there were several other things to do. The first was the Great Barrier Reef. Maurice Yonge had lead the 1928-1929 expedition to Low Isles and beyond, and Alfred [Steers] had been on that and then went back in 1935. Both approached the University of Queensland, and it was agreed the time was right for another expedition in 1973". The 1973 Royal Society-Universities of Queensland Expedition to the northern Great Barrier Reef was the largest and logistically the most complex expedition that David Stoddart ever led. The 'Stoddart Expedition', as it became known, lasted for four months. It was divided into three separate phases, involved four vessels, 10 projects and 25 participants. Results of the expedition were presented at a Discussion Meeting at the Royal Society, London in January 1976 and were published in both Series A (Mathematical, Physical and Engineering Sciences) and Series B (Biological Sciences) of the Philosophical Transactions of the Royal Society in 1978.

Four papers relating specifically to the expedition are reported here, three of which include four members of the 1973 expedition as authors. The first by JEN (Charlie) Veron (this issue p. 61-66) is a short and very personal account that focuses on the last phase (Phase III) of the expedition to the then virtually unknown northernmost sector of the Great Barrier Reef. Veron cites three highlights of this 'voyage of discovery': the identification of 'deltaic reefs' on the outer barrier reef; the first SCUBA dives off the near-vertical oceanside slope of one of the ribbon reefs (Tijou); and, a survey of isolated Raine Island, later to become a major component of the Great Barrier Reef World Heritage conservation area. The second paper by Peter Flood (this issue p. 67-78) deals with shoreline changes over a period of four decades on one of the best known and most visited sand cays towards the southern end of the Great Barrier Reef, Heron Island. In that contribution Flood argues that because many of the agents of 
change on Heron Island result from human activities, the island should not be regarded as a natural laboratory and used in studies of changes in sand cay shape and dimensions in response to external environmental conditions, sea-level rise and climate change.

The two other papers on the Great Barrier Reef trace their roots back to the work of the 1973 expedition. Smithers, Hopley and McLean (this issue p.79-103) reflect on the last four decades of debate about Holocene sea level history on the Great Barrier Reef and the legacy of the 1973 expedition to that debate. They list four key contributions of the expedition: a critique of palaeo sea level indicators; recognition of the significance of coral microatolls as sea level recorders; unequivocal evidence of Holocene high sea levels in the northern Great Barrier Reef; and, that differences in palaeo sea level across and along the reef could be explained by hydro-isostacy. Since that time a large number of studies have been carried out in the region, and these are reviewed in relation to the 1973 expedition conclusions.

In addition to geomorphic work during the 1973 expedition David Stoddart undertook vegetation surveys (and plant collections) on many of the islands of the northern Great Barrier Reef. This work followed a lifelong interest in species-area relationships as a key element of biogeographical theory and the centrality of datasets on coral island floristics to these debates, most notably catalyzed by MacArthur and Wilson's monograph 'The Theory of Island Biogeography', published in 1967. Stoddart was able to argue, working with Ray Fosberg and Colin Woodroffe respectively, that MacArthur and Wilson's Dry Tortugas dataset is seriously flawed and that the patterns seen at Kapingamarangi, central Pacific Ocean are probably the product not simply of island area but rather the result of a more complex set of ecological, physical and substrate interactions. Taking forward this latter critique, Sarah Hamylton (this issue p. 105-119) has used data from 28 of these islands together with surveys from the southern Great Barrier Reef to investigate the pattern in the number of plant species on 43 islands. Using measures of spatial autocorrelation to explore the relationship between plant population diversity between islands, and a number of geographical factors such as island area, island isolation, distance from mainland etc. she identifies significant differences between the northern and southern islands, and suggests those differences are related to several geographical factors including the depth of the lagoon floor and Holocene sea level history.

Reef platform vegetation, in this case mangroves, is also the theme of the paper by another of David Stoddart's former PhD students, Colin Woodroffe (this issue p. 121-145). Woodroffe returns to the Belize atolls, and specifically the un-atoll-like Turneffe Islands where mangroves occupy over $25 \%$ of the reef platform. Mangroves also occupy other 'islands' or 'ranges' within the Belize barrier and these are compared with the mangrove cover on the 'low wooded islands' of the Great Barrier Reef. Woodroffe argues that the contrast between mangrove extent and diversity on the islands of the Belize coast and those in the northern province of the Great Barrier Reef provide many insights into the geomorphology of both reefs and morphodynamics of the islands that form on them.

The last two papers in this volume are formerly unpublished contributions by Stoddart. Each has an introduction that provides some background to the papers that follow (Spencer and Hamylton, this issue p. 147-148; Dobbs, this issue p. 159). The first, with co-author Frank Murphy (this issue p. 149158), deals with the last location, French Polynesia, that Stoddart worked in (following many expeditions to the Cook and Austral Islands), being based at the University of California's Gump Research Station on Moorea. His concern about survey accuracy, tidal datums and the interpretation of results is related with specific reference to surveys and interpretations in the atolls and islands of French Polynesia a critique that he also levels at some of the field expeditions he was associated with. As the introduction to this paper makes clear, whilst new satellite-based survey techniques solve some of the problems that Stoddart and Murphy identify, the need to interpret island elevations within a strong understanding of local environmental setting, and location-specific error terms, remain as relevant today as they did when Stoddart and Murphy carried out their meticulous surveys in the Society Islands and the Tuamotu Archipelago over 25 years ago. 
In later years, when field work became more arduous and his health began to fade, Stoddart's interests returned to reviewing some of the great personalities in the history of coral reef research. Earlier he had written several works on Darwin, Lyell, Jukes, W.M. Davis, Dana and now it was Alexander Agassiz (Stoddart, this issue p. 161-185). We are enormously grateful to David Dobbs for his wonderful introduction to this massive, lost manuscript (p. 159-160) which typifies the deep scholarship that was the hallmark of all Stoddart's research into the history of coral reef science. And David writes 'I am so pleased and flattered to contribute even four modest paragraphs to the Atoll [Research] Bulletin a publication that came into hand and under my eyes so many times, and brought visions each time of glittering water, shimmering coral, and Darwin.' What better place, on the eightieth anniversary of his birth, could there be to gather together a tribute to David Stoddart?

As editors of this special issue of the Atoll Research Bulletin we wish to thank all contributors for their cooperation and commitment as well as acknowledging Marguerite Toscano, editor of the Bulletin for her support throughout this venture. Finally, we have been greatly honored to have Ian Macintyre write the foreword to this series of papers. Ian's close professional and personal engagement with David - and their joint involvement in the Bulletin - spanned over forty years. His personal reflections and generous comments resonate with all of us who knew David Stoddart.

Roger McLean and Tom Spencer

November 2017 


\section{DAVID STODDART'S WRITING ON CORAL REEFS, 1960-2008 'So many expeditions, so many projects, so many papers, so much laughter'}

\section{TOM SPENCER ${ }^{1}$}

David Stoddart's first output on coral reefs was a report from his undergraduate expedition to Belize (then British Honduras) in 1959-1960 (Stoddart, 1960²); his last as co-author on the chapter on coral reefs in Volume 4 of the History of the Study of Landforms (Spencer et al., 2008). In between these two outputs, he produced a further 239 items: an astonishing outpouring of scientific papers, reports, monographs, conference proceedings and book chapters; book reviews and commentaries; extensive bibliographies on coral reefs and related topics; and letters to 'The Times' ${ }^{3}$. Has anyone else in the history of reef science been quite so prolific? (David of course is probably the only person who could have answered this question). Remarkably, almost $90 \%$ of these outputs were first authored and, of these, almost $70 \%$ were single authored. The range of material covered, by a scientist based in a Department of Geography, was quite unbelievable ${ }^{4}$, echoing Stoddart's view of the place of Geography within the natural sciences: 'Colleagues on my expeditions have often expressed surprise that a student of geomorphology, sedimentology, botany and zoology should work in a department of geography. I share no such feeling: I am a geographer, and my work lies squarely in a great tradition... My geography springs from Forster, Darwin, Huxley: and it works' (Stoddart, 1986: ix). His second offering in the Atoll Research Bulletin was the publication of Charles Darwin's original notes on the structure and distribution of coral reefs that he had unearthed in the Cambridge University Library. He was acutely aware of this research lineage: 'four handshakes from Darwin' as he memorably told the European meeting of the International Society for Reef Studies in Cambridge in 2002.

This enormous output was underpinned by a huge, sustained (at least three research trips a year to the reef seas, maintained over decades) commitment to fieldwork, ranging from opportunistic individual visits (the paper on the sand cays of Tongatapu (Stoddart, 1975) was the result of a wait between aircraft and the fieldwork for the paper on African Banks, Amirantes archipelago (Stoddart and Poore, 1970) undertaken while the research vessel was grounded on the reef), to work leading small teams (where participants were referred to by nickname: 'the dog', 'scruffy', 'the vicar'...) to large, multi-disciplinary ventures - such as the marine programme of the Solomon Islands Expedition (1965; led by the botanist E.J.H. Corner) and the Northern Great Barrier Reef Expedition (1973; led by Stoddart himself) - that ranged widely, lasted for many months and led to impressive synthesis volumes in the Royal Society of London's Philosophical Transactions, the academy that promoted and funded many of the expeditions themselves, through its Southern Zone Research Committee and its overseas research funds (alongside transport arrangements often provided by MATS in the USA and the RAF and the Royal Navy in the UK). To Stoddart it was entirely appropriate that 'the Royal' should be involved in this way. From its very beginnings, the Society had wished to expand knowledge of the world's oceans, issuing 'Directions to seamen bound for far voyages' in the first volume of the Transactions, and that support can be traced for over 300 years (Spencer, 2011).

Between 1959 and 1965, Stoddart 'had worked in the Caribbean, the Indian Ocean, and the Pacific, even if only dipping my toe in the waters' (Stoddart, 2001:248). This was reflected in a clear rising trend in publication activity, reaching a clear spike in the year 1971 (Figure 1). David was fond of saying how he had published his way through the alphabet in a single year. The reality was that for single authored papers in 1971 he reached the letter ' $t$ ' (Stoddart 1971); if one adds in co-authored papers he had 25 reef-related publications in that year, just one shy of the magical $26^{5}$. From the mid-1970s to the mid1980 s, he sustained an average publication output of reef material of over 8 articles a year; over the next

\footnotetext{
${ }^{1}$ Cambridge Coastal Research Unit, Department of Geography, University of Cambridge, Downing
} Place, Cambridge CB2 3EN, U.K. 
decade this fell to just over 3 articles per year and then post-1996 to less than 1 article per year as ill health seriously curtailed his productivity (Figure 1a). As his earlier expeditionary activity became no longer possible, so the focus of his reef publications shifted towards a greater focus on the history of reef science (Figure 1b).
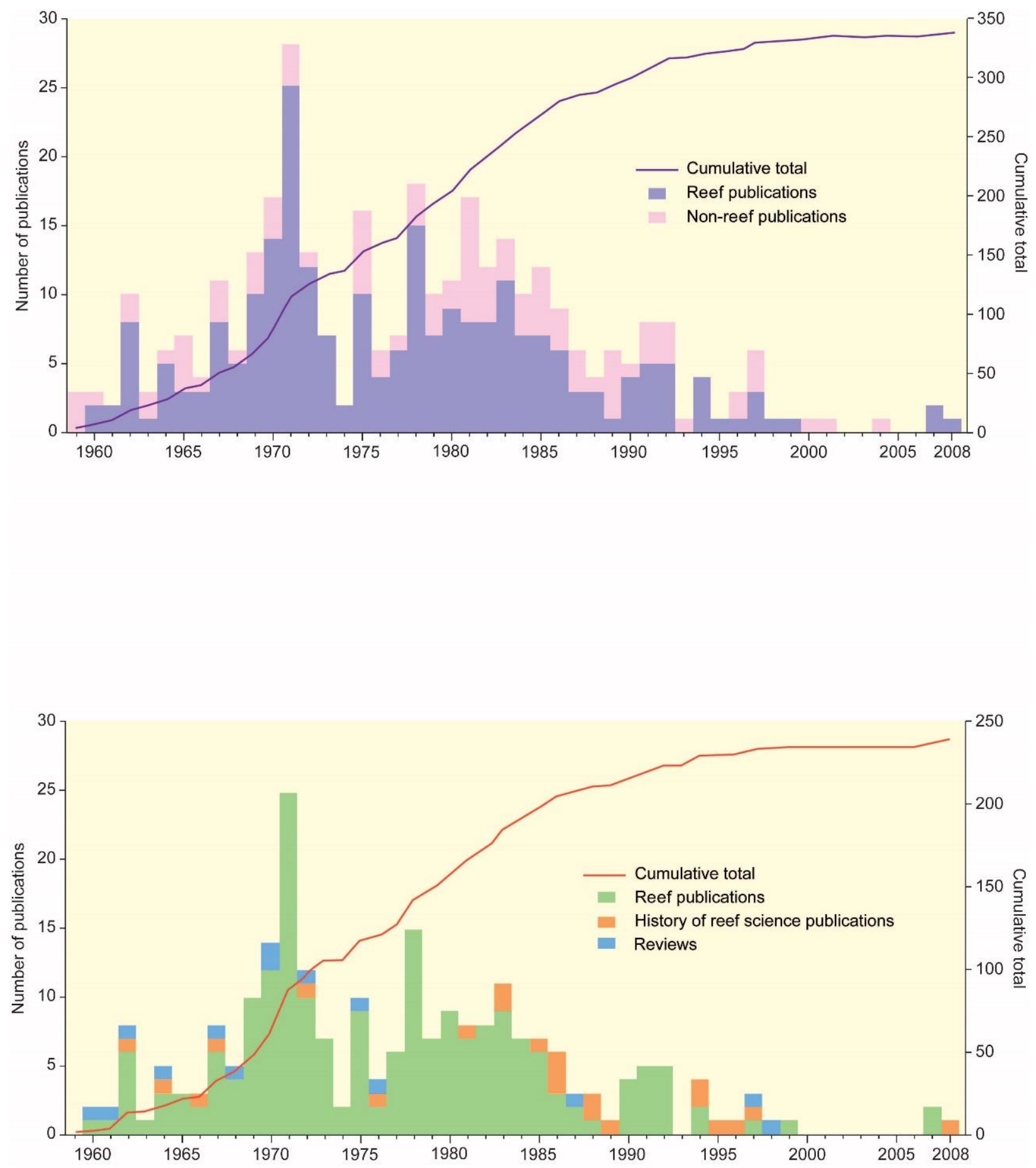

Figure 1. (a; upper panel) David Stoddart's reef and non-reef publications by year, 1959-2008, and cumulative total; (b; lower panel) Reef publications by type of publication, 1960-2008. 
One of Stoddart's great mantras to young graduate students was 'unpublished research is not research'. It is remarkable how quickly some publications appeared after the underpinning fieldwork, although of course the major expeditions took longer to be synthesised into major publications. Thus the outputs of the Royal Society research programme to Aldabra Atoll appeared in almost 1,000 pages of published material in the Transactions in 1971 and 1979 and was followed by the Biogeography and Ecology of the Seychelles Islands (at almost 700 pages) in 1984. In between times came the results of the 1973 Northern Great Barrier Reef Expedition in the same journal in 1978; its complete first draft considerably exceeding the final printed 360 pages (unpublished C. M. Yonge correspondence files, British Museum (Natural History)). Some material surfaced under other names (i.e. the massive 73 pages Agassiz typescript (Stoddart, n.d.) generously given (and generously acknowledged) that lies behind David Dobbs' 'Reef Madness' (Dobbs, 2011) and the skeletons of some projects came to be filled out under other editors (e.g. Brunt and Davies, 1994)). Many readers of this paper will know of typescripts and projects that still lie unpublished in the 14 filing cabinets of 'island files' in California, not least the 'Atlas of Coral Reefs' that David carried around to the international reef conferences to be annotated in a fashion akin to the accumulation of reef descriptions from sea captains and travellers by Charles Darwin at Down House.

In terms of geographical spread, David Stoddart was very proud of the claim that he had worked in all the major reef provinces and that this gave him a great advantage in being able to 'read' reef systems, and their likely evolutionary pathway, throughout the reef seas (Figure 2 and Figure 3 ).
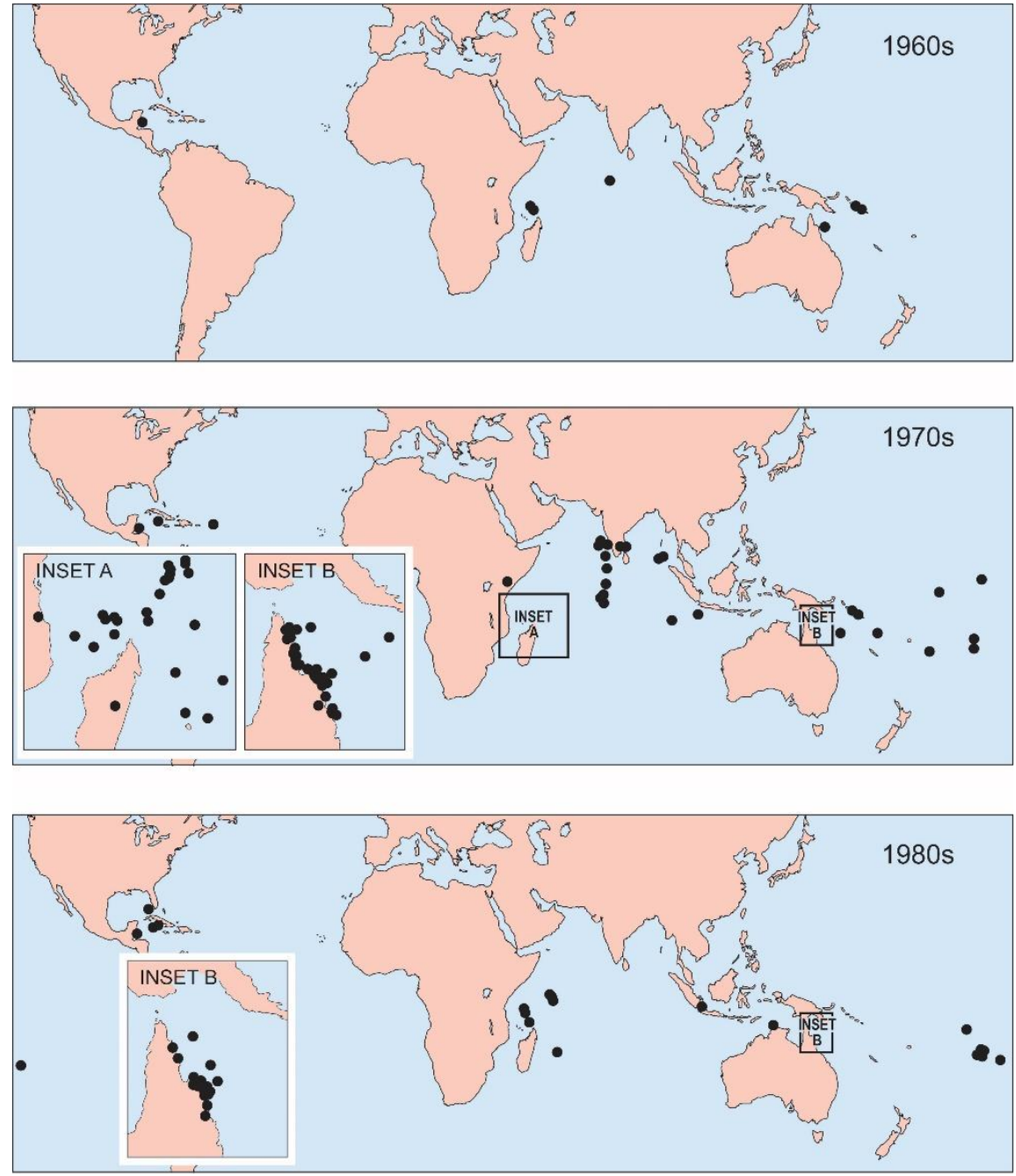

Figure 2. Location of David Stoddart's reef publications by location, 1960s, 1970s, 1980s. Note: plotted by date of publication rather than by the date of the underpinning fieldwork. 

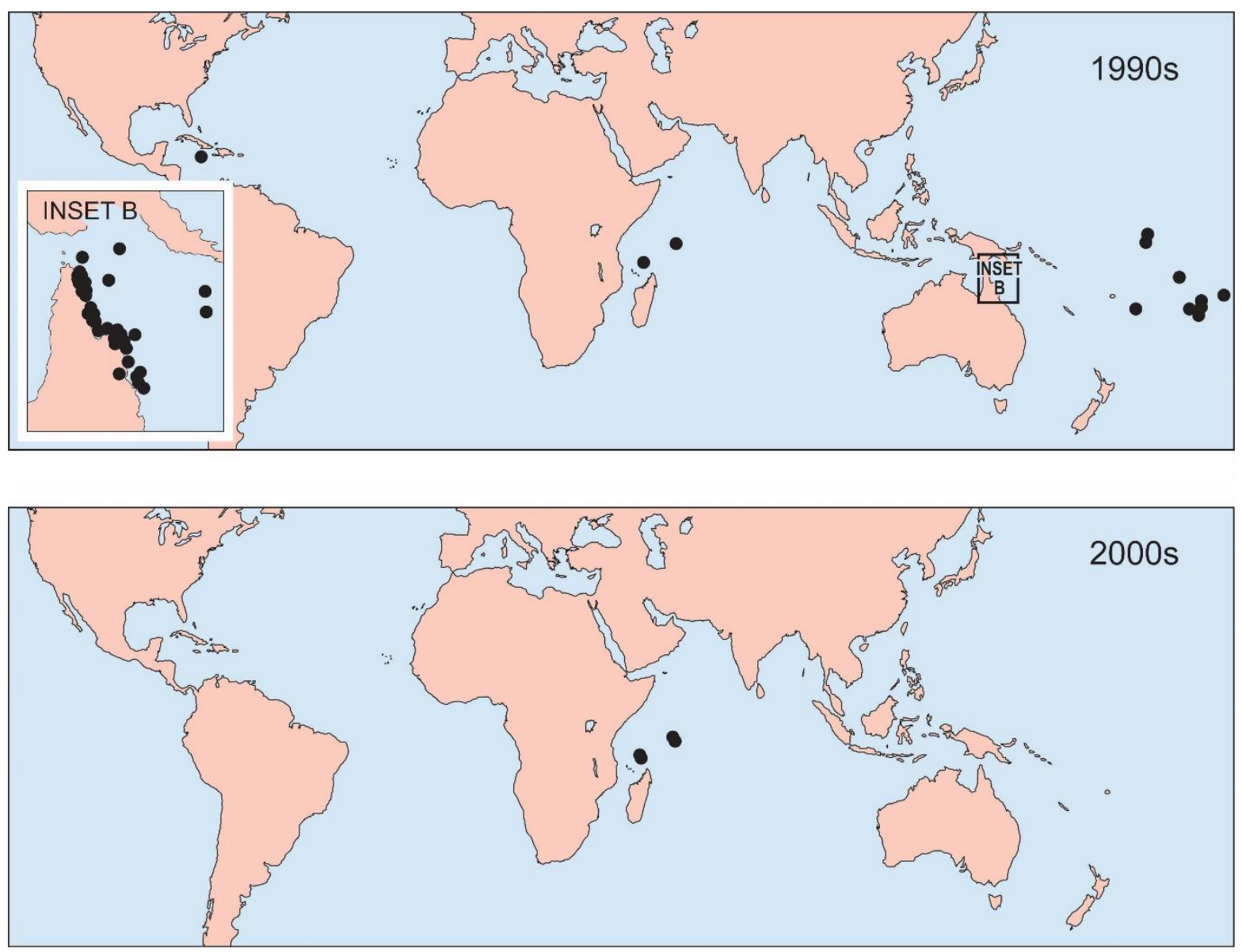

Figure 3. Location of David Stoddart's reef publications by location, 1990s, 2000s.

He was a strong believer in the value of the comparative method, one of the two great devices (the other being Linnean classification...) of the $18^{\text {th }}$ century 'used to bring the huge diversity of nature revealed by this new wave of exploration within the bounds of reason and of comprehension' (Stoddart, 1982a, 292) and which, in a reef context, he traced back to Reinhold Forster, the brilliant naturalist of James Cook's second Pacific voyage (for an example of the explanatory power and insight of this method see the buried-away discussion of algal rims in Stoddart (1977)). The core of David's field-based coral reef research shifted geographical focus over time. Plotting publications by location in the reef seas shows the scattered reach of the 1960s; the pan-Indian Ocean and western Pacific focus of the 1970s and 1980s (Figure 2); the shift to the SW Pacific in the 1990s; and the return to the western Indian Ocean post-2000 (Figure 3).

There were two locations where there was a constant interest. On the Belize Barrier Reef he revisited time and time again the sites that he had surveyed in 1959 and in the aftermath of Hurricane Hattie in October 1961. And in the Indian Ocean, he first visited Aldabra Atoll in 1966 with his final trip being in December 2007. Aldabra, its geomorphology, ecology and conservation was at the heart of David's concern for the health and future of reefs and reef islands (see also Stoddart, 1982b) and he never let up here; there are 38 directly related Aldabra outputs in his bibliography. David is rightly remembered for establishing the ecological significance of the island and energising its saving from military development but there was also the determination to construct a field station in this remotest of locations and oversee a decade-long, 50 person-year research effort on the atoll's geology, geomorphology, climate and ecology.

Finally, it is entirely fitting that Stoddart's coral reef bibliography should be published in the Atoll Research Bulletin. He first met Raymond Fosberg and Marie-Hélène Sachet in Washington D.C. in 1961 
and became a member of the Editorial Board in 1969. He first published in the Bulletin - 'Three Caribbean atolls: Turneffe Islands, Lighthouse Reef, and Glover's Reef, British Honduras' - as Volume 87, issued on 30 June 1962. His last contribution, no. 544, the edited volume on tsunamis and coral reefs, came out exactly 45 years later, on 1 July 2007. In total there were 74 contributions to the Bulletin ${ }^{6}$. Some of these were rather short - such as ARB 136 on historical records of the blue pigeon of Farquhar and Providence written with CW 'birdy' Benson (Stoddart and Benson, 1970) - but many were extraordinary compilations, such as the 180 pages of text on Little Cayman (Stoddart and Giglioli, 1980) and the over 200 pages description of Diego Garcia (Stoddart and Taylor, 1971). These papers tended to show a common structure: pages on background regional bathymetry and island geomorphology; climate; vegetation communities (and sometimes floristics); terrestrial fauna (often strongly focussed on island birds); settlement and exploitation; and threats and island conservation issues. Most island records were considerably enhanced by a deep knowledge of the reports of early explorers and travellers, painstakingly and thoroughly assembled in a pre-internet era. Following the text were maps of cays and islands, constructed from David's compass and pace mapping of island perimeters (no GPS here...) and drawn up in a wonderfully clean style by Michael Young in the Cartography Office of the Department of Geography at Cambridge. The maps were then followed by pages of black and white prints taken with one of the pair of Pentax cameras that David always carried in the field (with colour slide film in the second camera ${ }^{7}$ ). The whole was then meticulously pasted up as camera-ready copy for ultimate Bulletin hard copy. Of course, for many of these atolls and reef island locations, David's descriptions are the only descriptions. Like the man himself, nothing quite like them is going to come along again soon.

\section{ACKNOWLEDGEMENTS}

Most attempts at assembling bibliographies struggle with accurately documenting early, and often ephemeral, publications. Here, in a classic example of Stoddartian perversity, the early record is extremely well documented and it is the outputs from the later years have been much more difficult to uncover. Whilst in Cambridge, David meticulously updated his CV at regular intervals (his list of publications was kept in his desk in the Department of Geography alongside other forms of literature which are best not described) but his record keeping was much less secure when ill health made life so much more difficult in Berkeley. I am greatly indebted to Michael Stoddart for finding and scanning one of the early lists of publications; assembling the bibliography would have been totally impossible without his help. I hope that the whole family - June, Michael, Aldabra and granddaughter Kathy - will be pleased with, and proud of, this compilation.

\section{NOTES}

${ }^{2}$ David Stoddart's reef bibliography follows this contextual note; referencing here is separate from that bibliography. The title of this note is taken from the closing lines of Stoddart (2001).

${ }^{3}$ David published a further 100 items on broader geographical topics, so the career total weighs in at 341.

${ }^{4}$ What other Geographer would have contemplated - let alone written - and published a paper entitled 'Pinnipeds or sirenians at Western Indian Ocean islands?' (Stoddart, 1972h (you will have to read the paper to find out...)).

${ }^{5}$ Stoddart did get to 28 publications in 1971, with his additional 'geographical' publications.

${ }^{6}$ The online Smithsonian catalogue (http://www.sil.si.edu/DigitalCollections/atollresearchbulletin/) lists 42 ARB outputs. This is because it only reports the ARB issue as a whole not the constituent papers within an issue. 
${ }^{7}$ The iconic black film canisters could be extremely useful for other purposes; I remember drinking neat gin from a couple of them with David on Cayman Brac back in the 1970s.

\section{REFERENCES}

Brunt, M and Davies, J. E. (eds.) 1994. The Cayman Islands: Natural History and Biogeography (Monographiae Biologicae), Dordrecht: Kluwer Academic, xx+604pp.

Dobbs, D. 2009. Reef madness: Charles Darwin, Alexander Agassiz and the meaning of coral. New York: Pantheon Books, 320 pp.

Spencer, T. 2011. 'Royal Society of London' in: Hopley, D., Cabioch, G., Davies, P., Done, T.J., Gischler, E., Macintyre, I.G., Wood, R. and Woodroffe, C.D. (eds.), Encyclopaedia of Modern Coral Reefs: Structure, Form and Process (Encyclopaedia of Earth Sciences Series), Berlin: Springer, 938-940.

Spencer, T., Stoddart, D. R. and McLean, R. F. 2008. 'Coral Reefs', in Burt, T.P., Chorley, R.J., Brunsden, D., Cox, N.J. and Goudie, A.S. (eds.), History of the Study of Landforms or the Development of Geomorphology, Vol 4: Quaternary and Recent Processes and Forms (1890-1965) and the Mid-Century Revolutions, London: The Geological Society, 863-922.

Stoddart, D. R. 1960. 'The Reefs and Sand Cays of British Honduras', General Report, Cambridge Expedition to British Honduras 1959-60, 16-22.

Stoddart, D. R. 1971. 'White-throated rail Dryolimnas cuvieri on Astove Atoll', Bulletin of the British Ornithologists Club, 145-147.

Stoddart, D. R. 1975. 'Sand cays of Tongatapu, Southwest Pacific Ocean', Atoll Research Bulletin, $181,1-8$.

Stoddart, D. R. 1977. 'Structure and ecology of Caribbean coral reefs', FAO Fisheries Reports, 200, 427-488.

Stoddart, D. R. 1982a. 'Geography: a European science', Geography, 67(297), 289-296.

Stoddart, D. R. 1982b. 'Coral reefs: the coming crisis' Proceedings of the 4th International Coral Reef Symposium. Manila, 1, 33-36.

Stoddart, D. R. 1986. On Geography and its History. Oxford: Basil Blackwell, xi +335 pp.

Stoddart, D. R. 2001. 'Be of good cheer, my weary readers, for I have espied land', Atoll Research Bulletin, 494, 235-272.

Stoddart, D. R. n.d. 'Alexander Agassiz and coral reef controversy' (this volume)

Stoddart, D. R. and Benson, C. W. 1970 'An old record of a blue pigeon Alecoenas Species and sea birds on Farquhar and Providence', Atoll Research Bulletin, 136, 35-36.

Stoddart, D. R. and Giglioli, M. E. C. 1980. 'Geography and ecology of Little Cayman', Atoll Research Bulletin, 241, 1-180.

Stoddart, D. R. and Poore, M. E. D. 1970d. 'Geography and ecology of African Banks', Atoll Research Bulletin, 136, 187-191.

Stoddart, D. R. and Taylor, J. D. 1971. 'Geography and ecology of Diego Garcia Atoll, Chagos Archipelago', Atoll Research Bulletin, 149, 1-237.

Zinn, D. J. 1980. Alexander Agassiz (1835-1910) and the financial support of oceanography in the United States. M. Sears and D. Merriman, eds. Oceanography: the past. New York: Springer, 83-93. 


\section{APPENDIX}

\section{David Stoddart's Bibliography on Coral Reefs 1960-2008}

1960

Stoddart, D. R. (1960a) 'The Reefs and Sand Cays of British Honduras', General Report, Cambridge Expedition to British Honduras 1959-60, 16-22.

Stoddart, D. R. (1960b) Review of 'Land in British Honduras, Report of the British Honduras Land Use Survey Team, edited by D. H. Romney', Geographical Journal, 126(4), 525-526.

1961

Stoddart, D. R. (1961) Chapters 2, 4, 5, 6, 11, 14, 16 in D. Carr and J. Thorpe (eds.) From the Cam to the Cays: the Story of the Cambridge Expedition to British Honduras, London: Putnam. 191 pp.

Thorpe, J. E. and Stoddart, D. R. (1961) Review of 'Die landscaften von Nordost-Honduras by Karl Helbig', Geographical Journal, 127(4), 525-526.

1962

Stoddart, D. R. (1962a) 'A new theory of atoll formation', New Scientist, 16, 336-337.

Stoddart, D. R. (1962b) Review of 'Atoll Environment and Ecology by Herold J. Wiens', Geographical Journal, 128(4), 544-545.

Stoddart, D. R. (1962c) 'Catastrophic storm effects on British Honduras reefs and cays', Nature, 196, 512-515.

Stoddart, D. R. (1962d) 'Three Caribbean atolls: Turneffe Islands, Lighthouse Reef, and Glover's Reef, British Honduras', Atoll Research Bulletin, 87, 1-151.

Stoddart, D. R. (1962e) 'Coral Islands, by Charles Darwin, with introduction, map and remarks', Atoll Research Bulletin, 88, 1-20.

Stoddart, D. R. (1962f) 'Physiographic studies on the British Honduras reefs and cays', Geographical Journal, 128, 161-171.

Steers, J. A., Sweeting, M., Farmer, B. H., MacKie, E. W. and Stoddart, D. R. (1962) Cambridge Expedition to British Honduras: discussion. Geographical Journal, 128(2), 171-173.

Thorpe, J. E. and Stoddart, D. R. (1962) 'Cambridge Expedition to British Honduras', Geographical Journal, 128(2), 158-171.

1963

Stoddart, D. R. (1963a) 'Effects of Hurricane Hattie on the British Honduras reefs and cays, October 3031, 1961', Atoll Research Bulletin, 95, 1-142.

1964

Stoddart, D. R. (1964a) 'Carbonate sediments of Half Moon Cay, British Honduras', Atoll Research Bulletin, 104, 1-16.

Stoddart, D. R. (1964b) 'I.G.U. Commission on Coastal Geomorphology Bibliography 1959-1963: British Honduras', Folia Geographica Danica, 10, 11.

Stoddart, D. R. (1964c) 'Lt. Col. R. B. Seymour Swell', Atoll Research Bulletin, 108, 5-6.

Stoddart, D. R. (1964d) 'Storm conditions and vegetation in equilibrium of reef islands', Proceedings, 9th Conference on Coastal Engineering, 893-906.

Stoddart, D. R. (1964e) 'The shape of atolls', Marine Geology, 3, 369-383.

1965

Stoddart, D. R. (1965a) 'British Honduras cays and the Low Wooded Island problem', Transactions of the Institute of British Geographers, 36, 131-147.

Stoddart, D. R. (1965b) 'Re-survey of hurricane effects on British Honduras reefs and cays', Nature, 207, 589-592.

Stoddart, D. R. and Cann, J. R. (1965) 'Nature and origin of beach rock', Journal of Sedimentary Petrology, 35(1), 243-247.

1966

Stoddart, D. R. (1966a) 'Darwin's impact on geography', Annals of the Association of American 
Geographers, 56(4), 683-698.

Stoddart, D. R. (1966b) 'Reef studies at Addu Atoll, Maldive Islands: Preliminary results of an expedition to Addu Atoll in 1964', Atoll Research Bulletin, 116, 1-122.

Stoddart, D. R., Spencer-Davies, P. and Keith, A. S. (1966) 'Geomorphology of Addu Atoll', Atoll Research Bulletin, 116, 13-41.

1967

Stoddart, D. R. (1967a) 'A note on Charles Darwin and coral islands: Appendix IV' in N. Barlow, N. (ed.) Darwin and Henslow: the growth of an idea: Letters 1831-1860, London: Bentham-Moxon Trust and John Murray, 234-235.

Stoddart, D. R. (1967b) 'Ecology of Aldabra Atoll, Indian Ocean', Atoll Research Bulletin, 118, 1-141.

Stoddart, D. R. (1967c) 'Scientific studies on Aldabra Atoll', Atoll Research Bulletin, 118, 1-8.

Stoddart, D. R. (1967d) 'Summary of the ecology of coral islands north of Madagascar (excluding Aldabra)', Atoll Research Bulletin, 118, 53-61.

Stoddart, D. R. (1967e) 'Bibliography of Aldabra', Atoll Research Bulletin, 118, 127-141.

Stoddart, D. R. (1967f) 'Threats to Aldabra', Geographical Magazine, 800-808.

Stoddart, D. R. and Wright, C. A. (1967a) 'Ecology of Aldabra Atoll', Nature, 213, 1174-1177.

Stoddart, D. R. and Wright, C. A. (1967b) 'Geography and ecology of Aldabra Atoll', Atoll Research Bulletin, 118, 11-52.

1968

Stoddart, D. R. (1968a) 'Catastrophic human interference with coral atoll systems', Geography, 53, 2540.

Stoddart, D. R. (1968b) 'I.G.U. Commission of Coastal Geomorphology Bibliography 19631966: British Honduras' in A. Guilcher and A. Marec (eds.) Commission of Coastal Geomorphology Bibliography, 1963-1966. Paris: C.N.R.S., 20.

Stoddart, D. R. (1968c) 'Isolated island communities', Science Journal, 4(4), 32-38.

Stoddart, D. R. (1968d) 'The Aldabra Affair', Biological Conservation, 1, 63-69.

Stoddart, D. R. (1968e) 'The conservation of Aldabra', Geographical Journal, 134, 471-485.

1969

Stoddart, D. R. (1969a) 'Ecology and morphology of Recent coral reefs', Biological Reviews of the Cambridge Philosophical Society, 44(4), 433-498.

Stoddart, D. R. (1969b) 'Geomorphology of Solomon Islands coral reefs', Philosophical Transactions of the Royal Society of London Series B-Biological Sciences, 255, 355-382.

Stoddart, D. R. (1969c) 'Geomorphology of the Marovo elevated barrier reef, New Georgia', Philosophical Transactions of the Royal Society of London Series B-Biological Sciences, 255, 383-402.

Stoddart, D. R. (1969d) 'Islands as ecological laboratories', New Scientist, 41, 20-23.

Stoddart, D. R. (1969e) 'Reconnaissance geomorphology of Rangiroa Atoll, Tuamotu Archipelago, With List of vascular flora of Rangiroa by M.-H. Sachet', Atoll Research Bulletin, 125, 1-44.

Stoddart, D. R. (1969f) 'Post-hurricane changes on the British Honduras reefs and cays: re-survey of 1965', Atoll Research Bulletin, 131, 1-25.

Stoddart, D. R. (1969g) 'Reef morphology', Nature, 221, 978.

Stoddart, D. R. (1969h) 'Retrospect and prospect of Aldabra research', Nature, 221, 1004-1006.

Stoddart, D. R. (1969i) 'Sand cays of Eastern Guadacanal, Solomon Islands', Philosophical Transactions of the Royal Society of London B Biological Sciences, 55, 403-432.

Stoddart, D. R. and Thorpe, W. H. (1969) 'The Aldabra warblers', New Scientist, 41, 649.

1970

Stoddart, D. R. (1970a) Review of 'Coasts by E.C.F. Bird', Geographical Journal, 136, 137-137.

Stoddart, D. R. (1970b) Review of 'Coastal Landforms of Cat Island, Bahamas by Aulis O. Lind', Geographical Journal, 136, 282-283.

Stoddart, D. R. (1970c) 'Coral islands of the Western Indian Ocean: Introduction', Atoll Research Bulletin, 136, 1-5.

Stoddart, D. R. (1970d) 'Scientific studies at Aldabra and Neighbouring Islands', Philosophical 
Transactions of the Royal Society of London B Biological Sciences, 260, 5-29.

Stoddart, D. R. (1970e) 'Settlement, development, and conservation of Aldabra', Philosophical Transactions of the Royal Society of London B Biological Sciences, 260, 611-628.

Stoddart, D. R. and Benson, C. W. (1970) 'An old record of a blue pigeon Alecoenas Species and sea birds on Farquhar and Providence', Atoll Research Bulletin, 136, 35-36.

Stoddart, D. R., Benson, C. W. and Peake, J. F. (1970) 'Ecological change and effects of phosphate mining on Assumption Island', Atoll Research Bulletin, 136, 121-145.

Stoddart, D. R. and Poore, M. E. D. (1970a) 'Geography and ecology of Farquhar Atoll', Atoll Research Bulletin, 136, 7-26.

Stoddart, D. R. and Poore, M. E. D. (1970b) 'Geography and ecology of Desroches', Atoll Research Bulletin, 136, 155-165.

Stoddart, D. R. and Poore, M. E. D. (1970c) 'Geography and ecology of Remire', Atoll Research Bulletin, 136, 171-181.

Stoddart, D. R. and Poore, M. E. D. (1970d) 'Geography and ecology of African Banks', Atoll Research Bulletin, 136, 187-191.

Stoddart, D. R., Taylor, J. D., Fosberg, F. R. and Farrow, G. E. (1970) 'Geomorphology of Aldabra Atoll', Philosophical Transactions of the Royal Society of London B Biological Sciences, 260, 31-66.

Bayne, C. J., Cogan, B. H., Diamond, A. W., Frazier, J., Grubb, P., Hutson, A., Poore, M. E. D., Stoddart, D. R. and Taylor, J. D. (1970a) 'Geography and ecology of Cosmoledo Atoll', Atoll Research Bulletin, 136, 37-56.

Bayne, C. J., Cogan, B. H., Diamond, A. W., Frazier, J., Grubb, P., Hutson, A., Poore, M. E. D., Stoddart, D. R. and Taylor, J. D. (1970b) 'Geography and ecology of Astove', Atoll Research Bulletin, 136, 83-99.

1971

Stoddart, D. R. (1971a) 'Rainfall on Indian Ocean coral islands', Atoll Research Bulletin, 147, 1-21.

Stoddart, D. R. (1971b) 'Aldabra bibliography supplement', Atoll Research Bulletin, 148, 33-38.

Stoddart, D. R. (1971c) 'Scientific studies at Diego Garcia Atoll', Atoll Research Bulletin, 149, 1-6.

Stoddart, D. R. (1971d) 'Geomorphology of Diego Garcia Atoll', Atoll Research Bulletin, 149, 7-26.

Stoddart, D. R. (1971e) 'Diego Garcia climate and marine environment', Atoll Research Bulletin, 149, 27-30.

Stoddart, D. R. (1971f) 'Land vegetation of Diego Garcia', Atoll Research Bulletin, 149, 127-142.

Stoddart, D. R. (1971g) 'Terrestrial fauna of Diego Garcia and other Chagos atolls', Atoll Research Bulletin, 149, 163-170.

Stoddart, D. R. (1971h) 'Settlement and development of Diego Garcia', Atoll Research Bulletin, 149, 209-217.

Stoddart, D. R. (1971i) 'Bibliography of Diego Garcia', Atoll Research Bulletin, 149, 219-237.

Stoddart, D. R. (1971j) 'Conservation of the Phoenix Islands, central Pacific Ocean', Report to the Southern Zone Research Committee of the Royal Society, the Department of Education and Science, and the Foreign and Commonwealth Office. $20 \mathrm{pp}$.

Stoddart, D. R. (1971k) 'Coral reefs and islands and catastrophic storms' in J. A. Steers (ed.) Applied Coastal Geomorphology. London: Macmillan, 155-197.

Stoddart, D. R. (19711) 'Environment and history in Indian Ocean reef morphology' in D. R. Stoddart and C. M.Yonge (eds.) Symposia of the Zoological Society of London. London: Academic Press, 3-38.

Stoddart, D. R. (1971m) 'A Discussion on the results of the Royal Society Expedition to Aldabra 196768', Philosophical Transactions of the Royal Society of London, 260,1-654

Stoddart, D. R. (1971n) 'Scientific studies on Aldabra and neighbouring islands', Philosophical Transactions of the Royal Society of London Series B-Biological Sciences, 260(836), 5-29.

Stoddart, D. R. (1971o) 'Settlement, development, and conservation of Aldabra', Philosophical Transactions of the Royal Society of London Series B-Biological Sciences, 260, 611-628.

Stoddart, D. R. (1971p) 'Place names of Aldabra', Philosophical Transactions of the Royal Society of 
London Series B-Biological Sciences, 260, 631-632.

Stoddart, D. R. (1971q) 'Problems and prospects in Indian Ocean reef studies' in D. R. Stoddart and C. M. Yonge (eds.) Symposia of the Zoological Society of London. London: Academic Press, 549553.

Stoddart, D. R. (1971r) 'Sea-level change and the origin of sand cays: radiometric evidence', Journal of the Marine Biological Association of India, 11, 44-58.

Stoddart, D. R. (1971s) 'Variations on a coral theme', Geographical Magazine, 610-615.

Stoddart, D. R. (1971t) 'White-throated rail Dryolimnas cuvieri on Astove Atoll', Bulletin of the British Ornithologists Club, 145-147.

Stoddart, D. R., Gibbs, P. E. and Vevers, H. E. (1971) 'Coral reefs and associated communities in the Cook islands', Bulletin of the Royal Society of New Zealand, 8, 91-105.

Stoddart, D. R. and Taylor, J. D. (1971) 'Geography and ecology of Diego Garcia Atoll, Chagos Archipelago', Atoll Research Bulletin, 149, 1-237.

Stoddart, D. R., Taylor, J. D., Fosberg, F. R. and Farrow, G. E. (1971) 'Geomorphology of Aldabra Atoll', Philosophical Transactions of the Royal Society of London Series B-Biological Sciences, 260, 31-65.

Stoddart, D. R. and Yonge, C. M. (1971) 'Regional variation in Indian Ocean coral reefs', Symposia of the Zoological Society of London, 28, London: Academic Press. 584 pp.

Spencer-Davies, P., Stoddart, D. R. and Sigee, D. C. (1971) 'Reef forms of Addu Atoll, Maldive Islands' in D. R. Stoddart and C. M. Yonge (eds.) Symposia of the Zoological Society of London. London: Academic Press, 217-259.

1972

Stoddart, D. R. (1972a) 'Buchanan - the forgotten apostle', Geographical Magazine, 44, 858-862.

Stoddart, D. R. (1972b) 'British Honduras' in V. P. Zenkovich, V. Gudelis. and G. A. Orlova (eds.,) Commission on Coastal Geomorphology Bibliography 1967-1970. Vilnius: Periodika, 23.

Stoddart, D. R. (1972c) 'Catastrophic damage to coral reef communities by earthquake', Nature, 239, 5152.

Stoddart, D. R. (1972d) 'Opening remarks to scientific sessions', Proceedings of the Symposium on Corals and Coral Reefs (Biological Association of India, 1969). Mandapam. Xvii-xix.

Stoddart, D. R. (1972e) 'Field methods in the study of coral reefs', Proceedings of the Symposium on Corals and Coral Reefs (Biological Association of India, 1969). Mandapam. 71-80.

Stoddart, D. R. (1972f) 'Regional variation in Indian Ocean coral reefs', Proceedings of the Symposium on Corals and Coral Reefs (Biological Association of India, 1969). Mandapam. 155-174.

Stoddart, D. R. (1972g) 'Closing remarks', Proceedings of the Symposium on Corals and Coral Reefs (Biological Association of India, 1969). Mandapam. Xxi-xxii.

Stoddart, D. R. (1972h) 'Pinnipeds or sirenians at Western Indian Ocean islands?' Journal of Zoology, $167,207-217$.

Stoddart, D. R. (1972i) 'Reef islands of Rarotonga, with list of vascular flora by F. R. Fosberg', Atoll Research Bulletin, 160, 1-14.

Stoddart, D.R. (1972j) 'Conservation problems on Grand Cayman Island, West Indies', Unpublished typescript, Department of Geography, University of Cambridge, 31pp.

Stoddart, D. R. and Fosberg, F. R. (1972) 'South Indian sand cays', Atoll Research Bulletin, 161, 1-16.

Stoddart, D. R. and Pillai, C. S. G. (1972) 'Raised-reefs of Ramanathapuram, South India', Transactions of the Institute of British Geographers, 56, 111-125.

1973

Stoddart, D. R. (1973a) 'Coral reefs of the Indian Ocean', in O. A. Jones and R. Endean (eds.) Biology and Geology of Coral Reefs I: Geology I. New York: Academic Press. 50-92.

Stoddart, D. R. (1973b) 'Coral reefs: The last two million years', Geography, 5(3), 313-323.

Stoddart, D. R. (1973c) 'Coral researchers meet on the reef', Geographical Magazine, 45, 902.

Stoddart, D. R., Bryan, G. W. and Gibbs, P. E. (1973) 'Inland mangroves and water chemistry, Barbuda, West Indies', Journal of Natural History, 7(1), 33-46.

Stoddart, D. R., Fosberg, F. R. and Clapp, R. B. (1973) Visit to the Phoenix Islands 29 May to 12 June 
1973: preliminary report of Ecology Review Team. Washington DC: Smithsonian Institution. 5 pp.

Stoddart, D. R., Fosberg, F. R., Pelzl, ti W. and Spellman, D. L. (1973) Investigations of Marine Shallow Water Ecosystems (IMSWE): Progress Report - Terrestrial Investigations. Washington: Smithsonian Institution Environmental Science Program. 21 pp.

Stoddart, D. R. and Gopinadha Pillai, C. S. (1973) 'Coral reefs and reef corals in the Cook Islands, South Pacific' in R. Fraser (ed.) Oceanography of the South Pacific. International Symposium. Wellington, New Zealand, Feb. 9-15, 1972. Wellington, New Zealand: New Zealand National Commission for UNESCO, 475-483.

1974

Stoddart, D. R. (1974a) 'Post-hurricane changes on the British Honduras reefs: Re-survey of 1972', in A. M. Cameron et al. (eds.) Proceedings of the 2nd International Coral Reef Symposium, 473483.

Stoddart, D. R. (1974b) 'Variations on a coral theme' in D. Brunsden and J.C. Doornkamp (eds.) The unquiet landscape, Newton Abbot: David and Charles, 94-100.

1975

Stoddart, D. R. (1975a) 'Sand cays of Tongatapu, Southwest Pacific Ocean', Atoll Research Bulletin, $181,1-8$.

Stoddart, D. R. (1975b) 'Scientific studies in the Southern Cook Islands: Background and bibliography', Atoll Research Bulletin, 190, 1-30.

Stoddart, D. R. (1975c) 'Almost-atoll of Aitutaki: geomorphology of reefs and islands', Atoll Research Bulletin, 190, 31-57.

Stoddart, D. R. (1975d) 'Reef islands of Aitutaki', Atoll Research Bulletin, 190, 59-72.

Stoddart, D. R. (1975e) 'Vegetation and floristics of the Aitutaki motus', Atoll Research Bulletin, 190, $87-116$.

Stoddart, D. R. (1975f) 'Mainland vegetation of Aitutaki', Atoll Research Bulletin, 190, 117-122.

Stoddart, D. R. (1976g) 'British Honduras', in C. Kidson (ed.) Working Group on Dynamics of Shoreline Erosion Bibliography 1971-1974, 16-17.

Stoddart, D. R. (1975h) 'Seychelles, Mauritius, and the British Indian Ocean Territory', in C Kidson (ed.) Working Group on Dynamics of Shoreline Erosion Bibliography 1971-1974, 79-81.

Stoddart, D. R. and Gibbs, P. E. (1975) 'Almost Atoll of Aitutaki: Reef studies in the Cook Islands, South Pacific', Atoll Research Bulletin, 190, 1-158.

Stoddart, D. R. and Walsh, R. P. D. (1975) 'Environmental variability and environmental extremes as factors in the island ecosystem', Record of Proceedings of the 13th Pacific Science Congress, 1, 250.

Gibbs, P. E., Vevers, H. G. and Stoddart, D. R. (1975) 'Marine fauna of the Cook Islands: Checklist of species collected during the Cook Bicentenary Expedition in 1969', Atoll Research Bulletin, (190), 133-148.

1976

Stoddart, D. R. (1976a) 'Climatic variability, seabirds and guano in the central Pacific: a model for the Pleistocene?' International Geography, 23(3), 93-98.

Stoddart, D. R. (1976b) 'Continuity and crisis in the reef community', Micronesica, 12(1), 1-9.

Stoddart, D. R. (1976c) 'Darwin, Lyell, and the geological significance of coral reefs', British Journal for the History of Science, 9(32), 199-218.

1977

Stoddart, D. R. (1977a) 'Identity of pelicans on St Joseph Atoll, Amirantes', Bulletin of the British Ornithologists Club, 97, 94-95.

Stoddart, D. R. (1977b) 'Progress report: Biogeography', Progress in Physical Geography, 1, 537-543.

Stoddart, D. R. (1977c) Structure and ecology of Caribbean coral reefs, FAO Fisheries Reports, 200, $427-488$.

Stoddart, D. R. and Mole, L. U. (1977) 'Climate of Aldabra Atoll', Atoll Research Bulletin, 202, 1-21.

Stoddart, D. R. and Steers, J. A. (1977) 'Nature and origin of reef islands' in O. A. Jones and R. Endean 
(eds.) Biology and Geology of Coral Reefs IV: Geology II, London: Academic Press, 59-105.

Steers, J. A. and Stoddart, D. R. (1977) 'The origin of fringing reefs, barrier reefs, and atolls' in O. A. Jones and R., Endean (eds.) Biology and Geology of Coral Reefs IV: Geology II, London: Academic Press, 21-57

1978

Stoddart, D. R. (1978a) 'Descriptive reef terminology' , in D. R. Stoddart, and R. E Johannes (eds.), Coral Reefs: Research Methods, Paris: UNESCO, 5-15.

Stoddart, D. R. (1978b) 'Mapping reefs and islands', in D. R. Stoddart and R. E. Johannes (eds.) Coral Reefs: Research Methods. Paris: UNESCO. 17-22.

Stoddart, D. R. (1978c) 'Mechanical analysis of reef sediments', in D. R. Stoddart and R. E. Johannes (eds.) Coral Reefs: Research Methods. Paris: UNESCO. 53-66.

Stoddart, D. R. (1978d) 'Progress Report: Biogeography', Progress in Physical Geography, 2, 514-528.

Stoddart, D. R. (1978e) 'The Great Barrier Reef and the Great Barrier Reef Expedition 1973', Philosophical Transactions of the Royal Society A - Mathematical Physical and Engineering Sciences, 291, 5-22.

Stoddart, D. R. and Johannes, R. E. (1978) Coral Reefs: Research Methods, Monographs on Oceanographic Methodology, Vol 5. Paris: UNESCO. 581 pp.

Stoddart, D. R., McLean, R. F., Scoffin, T. P. and Gibbs, P. E. (1978) '45 years of change on Low Wooded Islands, Great Barrier Reef', Philosophical Transactions of the Royal Society of London Series B-Biological Sciences, 284(999), 63-80.

Stoddart, D. R., McLean, R. F., Scoffin, T. P., Thom, B. G. and Hopley, D. (1978) 'Evolution of reefs and islands, Northern Great Barrier Reef: synthesis and interpretation', Philosophical Transactions of the Royal Society of London Series B-Biological Sciences, 284, 149-159.

Stoddart, D. R. and Yonge, C. M. (1978a) The Northern Great Barrier Reef. London: The Royal Society. 366 pp.

Stoddart, D. R. and Yonge, C. M. (1978b) 'The Northern Great Barrier Reef. Part A of a Discussion', Philosophical Transactions of the Royal Society of London, A, 291, 1-197.

Stoddart, D. R. and Yonge, M. (1978c) 'The Northern Great Barrier Reef. Part B of a Discussion', Philosophical Transactions of the Royal Society of London B Biological Sciences, 285, 1-163.

McLean, R. F. and Stoddart, D. R. (1978) 'Reef islands and sediments of the Northern Great Barrier Reef', Philosophical Transactions of the Royal Society A - Mathematical Physical and Engineering Sciences, 291, 101-117.

McLean, R. F., Stoddart, D. R., Hopley, D. and Polach, H. (1978) 'Sea-level Change in the Holocene on the Northern Great Barrier Reef, Philosophical Transactions of the Royal Society A Mathematical Physical and Engineering Sciences, 291, 167-186.

Scoffin, T. P. and Stoddart, D. R. (1978) 'Nature and significance of microatolls', Philosophical Transactions of the Royal Society of London Series B-Biological Sciences, 284, 99-122.

Scoffin, T. P., Stoddart, D. R., McLean, R. F. and Flood, P. G. (1978) 'The recent development of the reefs in the northern province of the Great Barrier Reef', Philosophical Transactions of the Royal Society of London Series B-Biological Sciences, 284, 129-139.

1979

Stoddart, D. R. (1979) 'Aldabra and the Aldabra Research Station', Philosophical Transactions of the Royal Society of London Series B-Biological Sciences, 286, 3-10.

Stoddart, D. R. and Coe, M. J. (1979a) 'Geography and ecology of D'Arros Island', Atoll Research Bulletin, 223, 3-18.

Stoddart, D. R. and Coe, M. J. (1979b) 'Geography and ecology of St Joseph Atoll, Amirante Islands', Atoll Research Bulletin, 223, 27-42.

Stoddart, D. R. and Peake, J. F. (1979) 'Historical records of Indian Ocean giant tortoise populations', Philosophical Transactions of the Royal Society of London Series B-Biological Sciences, 286, 147-161.

Stoddart, D. R. and Scoffin, T. P. (1979) 'Microatolls: review of form, origin and terminology', Atoll Research Bulletin, 224, 1-17. 
Stoddart, D. R. and Walsh, R. P. D. (1979) 'Long-term climatic change in the Western Indian Ocean', Philosophical Transactions of the Royal Society of London Series B-Biological Sciences, 286, 11-23.

Stoddart, D. R. and Westoll, T. S. (1979) 'The Terrestrial Ecology of Aldabra', London: The Royal Society. 263 pp.

1980

Stoddart, D. R. (1980a) 'Destruction of Maya remains by shoreline erosion, Belize sand cays, Central America' in M. L. Schwartz (ed.) Proceedings of the Commission on Coastal Erosion Field Symposium. Bellingham: Western Washington University for the I.G.U. Commission.159-168.

Stoddart, D. R. (1980b) 'Environmental instability and South Pacific reefs'. Proceedings of the International symposium on Marine Biogeography and Evolution in the Southern Hemisphere (New Zealand D.S.I.R. Information Series, 1370). 147pp.

Stoddart, D. R. (1980c) 'Scientific survey of Little Cayman', Atoll Research Bulletin, 241, 1-10.

Stoddart, D. R. (1980d) 'Geology and geomorphology of Little Cayman Atoll', Atoll Research Bulletin, $241,11-16$.

Stoddart, D. R. (1980e) 'Vegetation of Little Cayman, British West Indies', Atoll Research Bulletin, 241, 53-69.

Stoddart, D. R. (1980f) 'Little Cayman, British West Indies: Ecology and significance', Atoll Research Bulletin, (241), 171-182.

Stoddart, D. R. (1980g) 'Mangroves as successional stages, inner reefs of the Northern Great Barrier Reef', Journal of Biogeography, 7(3), 269-284.

Stoddart, D. R. and Giglioli, M. E. C. (1980) 'Geography and ecology of Little Cayman', Atoll Research Bulletin, 241, 1-180.

Stoddart, D. R., Woodroffe, C. D. and Giglioli, M. E. C. (1980) 'Pleistocene patch reefs and Holocene swamp morphology, Grand Cayman Island, West Indies', Journal of Biogeography, 7, 103-113.

1981

Stoddart, D. R. (1981a) 'History of goats in the Aldabra Archipelago', Atoll Research Bulletin, 255, 2326.

Stoddart, D. R. (1981b) 'Abbotts Booby (Sula abbotti) on Assumption', Atoll Research Bulletin, 255, 2732.

Stoddart, D. R. (1981c) 'Darwin's influence on the development of geography in the United States, 1859-1914' in B. W Blouet (ed.) The origins of academic geography in the United States. Hamden: Archon Books, 265-278.

Stoddart, D. R. (1981d) 'Drift and Dispersal. Progress Report: Biogeography', Progress in Physical Geography, 5(4), 575-590.

Stoddart, D. R. and Fosberg, F. R. (1981a) 'Bird and Denis Islands, Seychelles', Atoll Research Bulletin, $252,1-50$.

Stoddart, D. R. and Fosberg, F. R. (1981b) 'Topographic and floristic change, Dry Tortugas, Florida, 1904-1977', Atoll Research Bulletin, 253, 1-55.

Stoddart, D. R., Gibbs, P. E. and Hopley, D. (1981) 'Natural history of Raine Island, Great Barrier Reef', Atoll Research Bulletin, 254, 1-44.

Polach, H. P., McLean, R. F., Thom, B. G., Stoddart, D. R. and Hopley, D. (1981) 'ANU Radiocarbon Date List VIII', Radiocarbon, 23, 1-14.

1982

Stoddart, D. R. (1982a) 'Coral reefs on the large-scale', Journal of the Geological Society, 139, 220-220.

Stoddart, D. R. (1982b) 'Coral reefs: the coming crisis', Proceedings of the 4th International Coral Reef Symposium. Manila. 33-36.

Stoddart, D. R., Brown, B. E. and Scoffin, T. P. (1982) British reef research - the next decade. Working Party Report for the Nuffield Foundation. 200 pp.

Stoddart, D. R., Cowx, D., Peet, C. and Wilson, J. R. (1982) 'Tortoises and tourists in the Western Indian Ocean: The Curieuse experiment', Biological Conservation, 24(1), 67-80.

Stoddart, D. R. and Fosberg, F. R. (1982) 'Species-area relationships on small islands: Floristic data from 
Belizean sand cays', Smithsonian Contributions to the Marine Sciences, (12), 527-539.

Stoddart, D. R., Fosberg, F. R. and Sachet, M. H. (1982) 'Ten years of change on the Glover's Reef cays', Atoll Research Bulletin, 257, 1-17.

Stoddart, D. R., Fosberg, F. R. and Spellman, D. L. (1982) 'Cays of the Belize barrier reef and lagoon', Atoll Research Bulletin, 256, 1-76.

Fosberg, F. R., Stoddart, D. R., Sachet, M. H. and Spellman, D. L. (1982) 'Plants of the Belize cays', Atoll Research Bulletin, 258, 1-77.

1983

Stoddart, D. R. (1983a) 'Darwin devalued or Darwin revalued? Progress report: Biogeography', Progress in Physical Geography, 7(2), 256-264.

Stoddart, D. R. (1983b) 'Grandeur in this view of life: Darwin and the ocean world', Bulletin of Marine Science, 33(3), 521-527.

Stoddart, D. R. and Ferrari, J. D. M. (1983) 'Aldabra Atoll: a stunning success story for conservation', Nature and Resources, 19(1), 20-28.

Stoddart, D. R. and Savy, S. (1983) 'Aldabra - island of giant tortoises', Ambio, 12(3-4), 180-185.

Stoddart, D. R. and Scoffin, T. P. (1983a) 'Phosphate rock on coral reef islands' in A. S Goudie and K. Pye (eds.) Chemical sediments and geomorphology. London: Academic Press, 369-400.

Stoddart, D. R. and Scoffin, T. P. (1983b) 'Beachrock and intertidal cements' in A. S. Goudie and K. Pye (eds.) Chemical sediments and geomorphology. London: Academic Press, 401-425.

Stoddart, D. R., Woodroffe, C. D. and Fosberg, F. R. (1983) 'Substrate-specific species distributions on Suwarrow Atoll, Central Pacific: Implications for island biogeography theory', Pacific Science Congress Proceedings, 15(1-2), 227-228.

Buckley, R. and Stoddart, D.R. (1983) 'Mangroves of Northern Great Barrier Reef islands, Australia', Pacific Science Congress Proceedings, 15(1-2), 29.

Fosberg, F. R., Sachet, M.-H. and Stoddart, D. R. (1983) 'Henderson Island (southeastern Polynesia): summary of current knowledge', Atoll Research Bulletin, 272, 1-47.

Sachet, M.-H., Stoddart, D. R. and Fosberg, F. R. (1983) 'Floristics and ecology of Western Indian Ocean islands', Atoll Research Bulletin, 273, 1-253.

Woodroffe, C. D., Stoddart, D. R., Harmon, R. S. and Spencer, T. (1983) 'Coastal morphology and Late Quaternary History, Cayman Islands, West Indies', Quaternary Research, 19(1), 64-84.

1984

Stoddart, D. R., (ed.) (1984a) Biogeography and ecology of the Seychelles Islands, Monographiae Biologicae, vol. 55. The Hague: W. Junk. 691 pp.

Stoddart, D. R. (1984b) 'Scientific studies in the Seychelles Islands' in D. R. Stoddart (ed.) Biogeography and ecology of the Seychelles Islands. The Hague: W. Junk, 1-15.

Stoddart, D. R. (1984c) 'Coral reefs of the Seychelles and adjacent regions' in D. R. Stoddart (ed.) Biogeography and ecology of the Seychelles Islands. The Hague: W. Junk, 63-81.

Stoddart, D. R. (1984d) 'Breeding seabirds of the Seychelles' in D. R. Stoddart (ed.) Biogeography and ecology of the Seychelles Islands. The Hague: W. Junk, 575-592.

Stoddart, D. R. (1984e) 'Impact of man in the Seychelles Islands' in D. R. Stoddart (ed.) Biogeography and ecology of the Seychelles Islands. The Hague: W. Junk, 641-654.

Stoddart, D. R. and Fosberg, F. R. (1984) 'Vegetation and floristics of western Indian Ocean coral islands' in D. R. Stoddart (ed.) Biogeography and ecology of the Seychelles Islands. The Hague: W. Junk, 221-238.

Stoddart, D. R. and Pethick, J. R. (1984) 'Environmental hazard and coastal reclamation: problems and prospects in Bangladesh' in T. P. Bayliss-Smith and S. Wanmali (eds.) Understanding Green Revolutions: Agrarian Change and Development Planning in South Asia. Cambridge: Cambridge University Press, 339-361.

1985

Stoddart, D. R. (1985a) 'Hurricane effects on coral reefs: conclusion'. Proceedings of the 5th International Coral Reef Congress. Tahiti. 349-350

Stoddart, D. R. (1985b) 'Appendix V. Darwin's early notes on coral reef formation' in F. Burkhardt and 14 
S. Smith (eds.) The Correspondence of Charles Darwin. Volume 1. 1821-1836. Cambridge: Cambridge University Press, 567-571.

Stoddart, D. R., Scoffin, T. P., Spencer, T., Harmon, R. S. and Scott, M. (1985) 'Sea-level change and karst morphology, Mangaia (Cook Islands)', Proceedings of the 5th International Coral Reef Congress. Tahiti, 3, 201.

Stoddart, D. R., Scoffin, T. P., Tudhope, A. W. and Woodroffe, C. D. (1985) 'Exposed limestone of Suwarrow Atoll', Proceedings of the 5th International Coral Reef Congress. Tahiti. 137-140.

Stoddart, D. R., Spencer, T. and Scoffin, T. P. (1985e) 'Reef growth and karst erosion on Mangaia, Cook Islands: a reinterpretation ', Zeitschrift für Geomorphologie, 57, 121-139.

Stoddart, D. R., Tudhope, A. W., Scoffin, T. P. and Woodroffe, C. D. (1985) 'Sediments of Suwarrow Atoll', Proceedings of the 5th International Coral Reef Congress. Tahiti. 611-616.

Scoffin, T. P., Stoddart, D. R., Tudhope, A. W. and Woodroffe, C. (1985) 'Rhodoliths and coralliths of Muri lagoon, Rarotonga, Cook Islands', Coral Reefs, 4(2), 71-80.

1986

Stoddart, D. R., (ed.) (1986a) On Geography and its History, Oxford: Basil Blackwell. 335 pp.

Stoddart, D. R. (1986b) 'Geography and its history' in D. R. Stoddart (ed.) On geography and its history. Oxford: Basil Blackwell, 1-27.

Stoddart, D. R. (1986d) 'Geography, discovery and exploration' in D. R. Stoddart (ed.) On geography and its history. Oxford: Basil Blackwell, 142-157.

Stoddart, D. R. (1986e) 'Putting the Geography back in the Bio-' in D. R. Stoddart (ed.) On geography and its history. Oxford: Basil Blackwell, 271-305.

Stoddart, D.R. (1986f) 'Umbgrove's islands revisited', in Brown, B.E., (ed.), Human induced damage to coral reefs, UNESCO Report in Marine Science, 40, 80-98.

Stoddart, D. R. (1986g) 'Marine research in the Northern Territory', Northern studies: a report of a workshop organised by the NT University Planning Authority held in Darwin in October 1984, $175-179$.

1987

Stoddart, D. R. (1987a) 'Giant tortoises', The Times 5 June 1987.

Stoddart, D. R. and Spencer, T. (1987) 'Rurutu Reconsidered: The development of makatea topography in the Austral Islands, South Pacific', Atoll Research Bulletin, 297, 1-20.

Spencer, T., Stoddart, D. R. and Woodroffe, C. D. (1987) 'Island uplift and lithospheric flexure: observations and cautions from the South Pacific', Zeitschrift für Geomorphologie, Supplementband, 63, 87-102.

1988

Stoddart, D. R. (1988a) 'The Duke, the Professors, and the Great Coral Reef Controversy of 1887-1888', Earth Sciences History, 7, 90-98.

Stoddart, D. R. (1988b) 'Joseph Beete Jukes, the 'Cambridge Connection', and the theory of reef development in Australia in the Nineteenth Century', Earth Sciences History, 7, 99-110.

Spencer, T., Stoddart, D. R., Woodroffe, C.D. and Harmon, R.S. (1988) Lithospheric flexure and raised limestones, S Cook-Austral Islands. Proceedings, Sixth International Coral Reef Symposium, Townsville 3, 485-489.

1989

Stoddart, D. R. (1989a) 'From colonial science to scientific independence: Australian reef geomorphology in the Nineteenth Century', in K.J. Tinkler (ed.), History of Geomorphology from Hutton to Hack, The Binghamton Symposia in Geomorphology International Series, no. 19. Boston: Unwin Hyman, 151-163.

1990

Stoddart, D. R. (1990) 'Coral reefs and islands and predicted sea-level rise', Progress in Physical Geography, 14(4), 521-536.

Stoddart, D. R. and Reed, D. J. (1990) 'Sea-level rise as a global geomorphic issue', Progress in Physical Geography, 14(4), 441-445.

Stoddart, D. R., Woodroffe, C. D. and Spencer, T. (1990) 'Mauke, Mitiaro and Atiu: Geomorphology of 
Makatea Islands in the Southern Cooks.', Atoll Research Bulletin, 341, 1-66.

Woodroffe, C. D., Stoddart, D. R., Spencer, T., Scoffin, T. P. and Tudhope, A. W. (1990) 'Holocene Emergence in the Cook Islands', Coral Reefs, 9(1), 31-39.

1991

Stoddart, D. R. and Fosberg, F. R. (1991a) 'Phytogeography and vegetation of the reef islands of the Northern Great Barrier Reef', Atoll Research Bulletin, 349, 1-20.

Stoddart, D. R. and Fosberg, F. R. (1991b) 'Plants of the Jamaican cays', Atoll Research Bulletin, 352, 124.

Ellison, J. C. and Stoddart, D. R. (1991) 'Mangrove ecosystem collapse during predicted sea-level rise Holocene analogs and implications', Journal of Coastal Research, 7(1), 151-165.

Fosberg, F. R. and Stoddart, D. R. (1991) 'Plants of the reef islands of the Northern Great Barrier Reef', Atoll Research Bulletin, 348, 1-82.

Woodroffe, C. D., Short, S. A., Stoddart, D. R., Spencer, T. and Harmon, R. S. (1991) 'Stratigraphy and chronology of Late Pleistocene reefs in the Southern Cook Islands, South Pacific', Quaternary Research, 35(2), 246-263.

1992

Stoddart, D. R. (1992a) 'Biogeography of the tropical Pacific', Pacific Science, 46(2), 276-293.

Stoddart, D. R. (1992b) 'Coral Reefs - the first decade', Coral Reefs, 11(3), 125-125.

Stoddart, D. R. (1992c) ' F. Raymond Fosberg and the Atoll Research Bulletin 1951-1991', Atoll Research Bulletin, 355,1-6.

Stoddart, D. R. and Walsh, R. P. D. (1992) 'Environmental variability and environmental extremes as factors in the island ecosystem', Atoll Research Bulletin, 356, 1-71.

Woodroffe, C. D. and Stoddart, D. R. (1992) 'Substrata specificity and episodic catastrophe: Constraints on the insular plant geography of Suwarrow Atoll, Northern Cook Islands', Atoll Research Bulletin, 362, 1-19.

1994

Stoddart, D. R. (1994a) 'Theory and reality: The success and failure of the deductive method in coral reef studies - Darwin to Davis', Earth Sciences History, 13, 21-34.

Stoddart, D. R. (1994b) "'This Coral episode": Darwin, Dana, and the coral reefs of the Pacific' in R.M. MacLeod, R.M. and P.F. Rehbock (eds), Darwin and the Pacific: Essays on Evolutionary Theory and Natural History in the Laboratory of the Pacific 1840-1920, Honolulu: University of Hawaii Press, 21-48.

Stoddart, D. R. (1994c) 'Introduction: Johannes Walther and his works on reefs, paleoecology and sedimentology' in R.N. Ginsburg, E.Gischler and W. Schlager (eds), Johannes Walther on Reefs: Pioneering concepts of biogeology 1885-1910, Geological Milestones, Volume II, Miami: Rosenthiel School of Marine and Atmospheric science, University of Miami, 3-9.

Stoddart, D. R. and Fosberg, F. R. (1994) 'The hoa of Hull Atoll and the problem of hoa', Atoll Research Bulletin, 394, 1-26.

Fosberg, F. R. and Stoddart, D. R. (1994) 'Flora of the Phoenix Islands, Central Pacific', Atoll Research Bulletin, 393, 1-60.

1995

Stoddart, D.R. (1995) 'Darwin and the seeing eye: Iconography and meaning in the Beagle years', Earth Sciences History, 14, 3-22.

1996

Stoddart, D. R. (1996a) "'A learned, intelligent, and judicious traveller"', Geographical Review, 86(4), 604-610.

1997

Stoddart, D. R. (1997a) 'Captain Cook and how we understand him', Geographical Review, 87(4), 537541.

Stoddart, D. R. (1997b) Bibliography of Aldabra and nearby Atolls (Third Edition), Mahé: Seychelles Islands Foundation. 
Stoddart, D. R. (ed.) (1997c) 'F.R. Fosberg Preliminary checklist of the flowering plants and ferns of the Society Islands'. University of California Berkeley, R. B. Gump South Pacific Biological Research Station, Moorea, French Polynesia, 179 pp.

1998

Stoddart, D. R. (1998) Review of 'Big surf, deep dives, and the islands: My life in the ocean by R.W. Grigg', Geographical Review, 88(4), 596-598

2001

Stoddart, D. R. (2001) 'Be of good cheer, my weary readers, for I have espied land', Atoll Research Bulletin, 494, 235-272.

2007

Stoddart, D. R. (ed.) (2007) Tsunamis and Coral Reefs, Atoll Research Bulletin 544, 164pp.

Hagan, A. B., Spencer, T., Stoddart, D. R., Loustau-Lalanne, M. and Renaud, R. (2007) 'Tsunami Impacts in the Republic of Seychelles, Western Indian Ocean', Atoll Research Bulletin, 544, 149164.

2008

Spencer, T., Stoddart, D. R. and McLean, R. F. (2008) 'Coral Reefs', in T. P. Burt, R. J. Chorley, D. Brunsden, N. J. Cox and A. S. Goudie (eds.), History of the Study of Landforms or the Development of Geomorphology, Vol 4: Quaternary and Recent Processes and Forms (1890-1965) and the Mid-Century Revolutions, London: The Geological Society, 863-922. 



\title{
MARINE RESEARCH IN THE BELIZE ATOLLS, GLOVERS REEF, LIGHTHOUSE REEF, AND TURNEFFE ISLANDS SINCE THE PIONEERING WORK OF DAVID STODDART: A REVIEW
}

\author{
EBERHARD GISCHLER ${ }^{1}$
}

\begin{abstract}
The Belize atolls Glovers Reef, Lighthouse Reef, and Turneffe Islands are among the few examples of Atlantic atoll reefs. They are part of the Belize barrier and atoll reef system, the largest reef structure in the Atlantic. The atolls, like the Belize Barrier Reef, have their foundations on NNE-trending, tilted fault-blocks of the passive continental margin. They are not located on subsiding volcanic edifices and therefore do not represent atolls in the sense of Charles Darwin (1842). It is striking that the geomorphologies of the Belize atolls are significantly different even though they are located in the same setting and close to one another. David Stoddart investigated the geomorphology of these atolls, mapped the biota and sediments of the reef islands, analyzed the significance of storm impact on reefs and islands, and discussed late Quaternary reef development. Although David Stoddart did not have any subsurface data, his conclusions are for the most part still valid today. His pioneering work forms the foundation of the wide variety of subsequent research on the Belize reef system in general and the offshore atolls in particular. Research includes sedimentology, reef development, marine biology, fisheries, ecology and paleoecology, and paleoclimate studies including sea-level research and paleotempestology.
\end{abstract}

\section{DAVID STODDART'S ACHIEVEMENTS BASED ON HIS WORK ON THE BELIZE ATOLLS}

There was hardly any knowledge of the reefs in Belize, especially of the offshore atolls, before David Stoddart started to work there in the late 1950s and early 1960s. One of the very few exceptions was the study by Smith $(1939,1941)$, the first dean of the University of Miami's marine science school, who investigated a curious sponge disease in the lagoon of the Turneffe Islands, large parts of which at that time were used for sponge farming. The disease was possibly caused by a combination of an unknown pathogen (fungus?) and extreme environmental conditions. For the early summer of 1939, Smith $(1939,1941)$ had reported drought, water temperatures of up to $31^{\circ} \mathrm{C}$, and salinities up to $70 \%$ in the Turneffe lagoon. Edward Purdy, then at Rice University in Houston, Texas, together with a number of students had begun looking at several geological aspects of the Belize barrier reef and the offshore atolls in the early 1960s (Gischler, 2010a). By this time both Stoddart and Purdy had begun their pioneering geomorphological and geological work on the atolls and reefs of the Belize coast, which they revisited over the next few decades (Figure 1).

\section{Geomorphology and Islands}

As a member of the Cambridge Expedition to British Honduras, David Stoddart first visited the Belize atolls during two expeditions in the late 1950s and early 1960s (Carr and Thorpe, 1961). Stoddart (1962a) collected data on bathymetry, hydrography, marine benthic fauna and flora, and mapped the reef

1 J.W. Goethe-Universität, Institut für Geowissenschaften, Altenhöferallee 1, 60438 Frankfurt am Main, Germany; Email: gischler@em.uni-frankfurt.de 


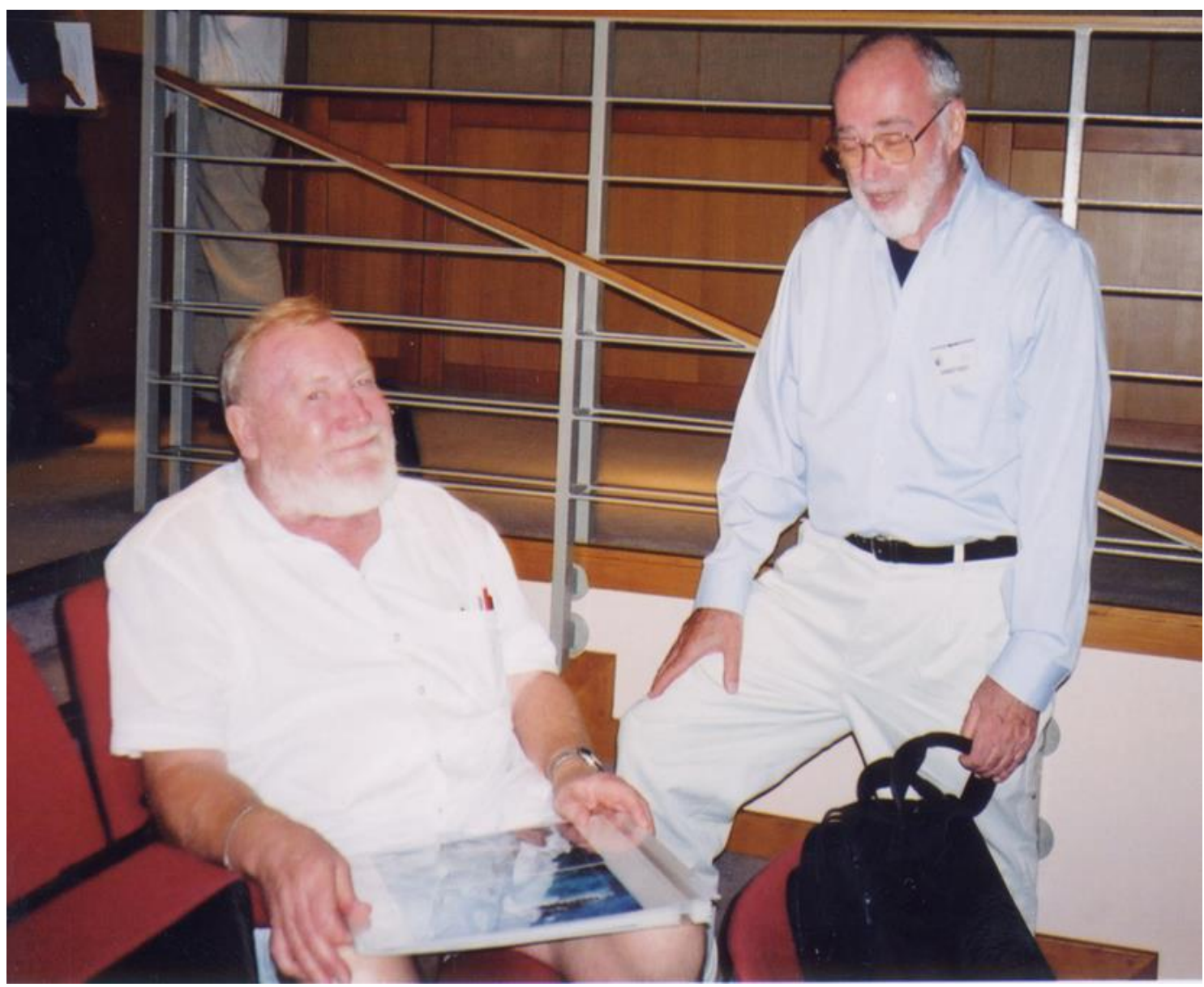

Figure 1. Two pioneers of reef research in Belize, David Stoddard (left) and Edward Purdy (right) 2002 at a meeting of the International Society for Reef Studies in Cambridge, U.K. (Photo by Gabriela Meyer, Frankfurt.)

islands in great detail.

The climate in Belize is tropical with sea surface temperatures ranging from $22-30^{\circ} \mathrm{C}$. Belize lies in the trade wind belt so winds from the northeast predominate. The area is microtidal with a tidal range of less than $0.5 \mathrm{~m}$. Annual precipitation increases from 1500 to $4000 \mathrm{~mm}$ from north to south. The three Belize atolls are located east of the Belize Barrier Reef and cover some $200 \mathrm{~km}^{2}$ (Lighthouse Reef), 260 $\mathrm{km}^{2}$ (Glovers Reef), and $525 \mathrm{~km}^{2}$ (Turneffe Islands), respectively (Figure 2). In Glovers Reef and Lighthouse Reef, land areas (cays) make up $<5 \%$ of the atoll; in Turneffe Islands, some $25 \%$ of the atoll comprises land (largely mangrove cays).

The atolls rise relatively steeply from the surrounding seabed. Marginal reefs enclose interior lagoons, with significantly different depths and geomorphological patterns (Figure 3). The northern atolls Turneffe and Lighthouse are up to $6.5 \mathrm{~m}$ and $9 \mathrm{~m}$ deep, respectively; Glovers Reef lagoon gets as deep as $37 \mathrm{~m}$, according to Stoddart (1962a) although systematic and comprehensive soundings in Glovers lagoon during later studies have not exceeded $18 \mathrm{~m}$ (Gischler, 1994; Gischler and Lomando, 1999).

Stoddart (1962a) reported 32 hard coral and Millepora species from the reefs, and presented underwater zonation profiles of atoll margins to $10 \mathrm{~m}$ water depth (Figure 4). Orbicella (formerly Montastraea) was identified as most abundant coral in the reefs. Lagoon reefs are rare, small and composed of depauperate fauna in the restricted lagoon of Turneffe Islands. Interestingly, the northernmost lagoon of Turneffe has open circulation with patch reefs. Lagoon reefs are common and arranged in a more or less linear, NNE-trending manner in the shallow Lighthouse lagoon. More than 850 


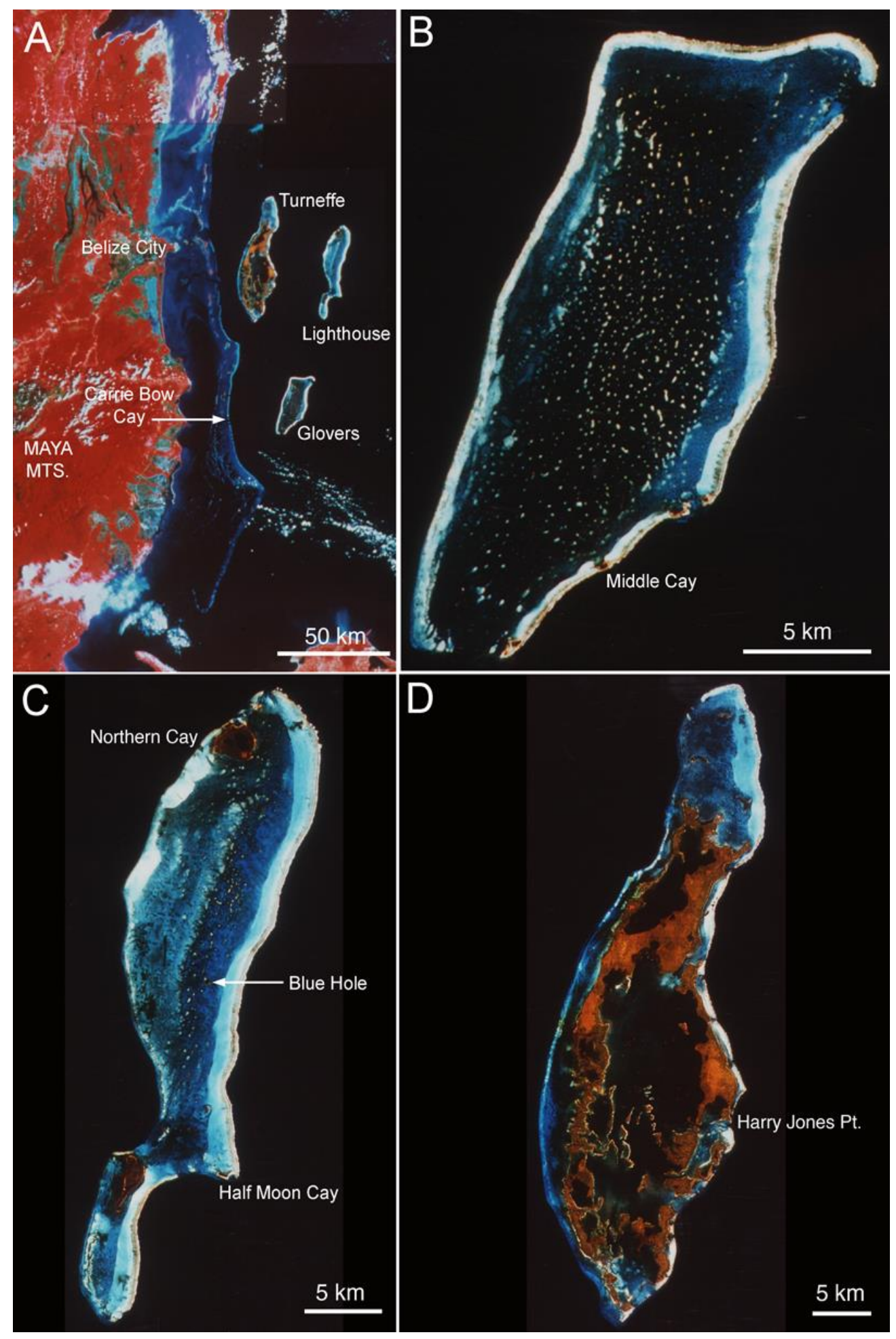

Figure 2. Satellite images of the Belize atolls (modified from Gischler and Lomando, 1999) and locations mentioned in the text. A. Belize reef system; mainland areas are red. B. Glovers Reef has a deep lagoon with numerous patch reefs. B. Lighthouse Reef with prominent linear trend of lagoonal patch reefs. C. Turneffe Islands with large areas covered by mangrove cays (brown). Note that northern platform area lacks large mangrove areas. 

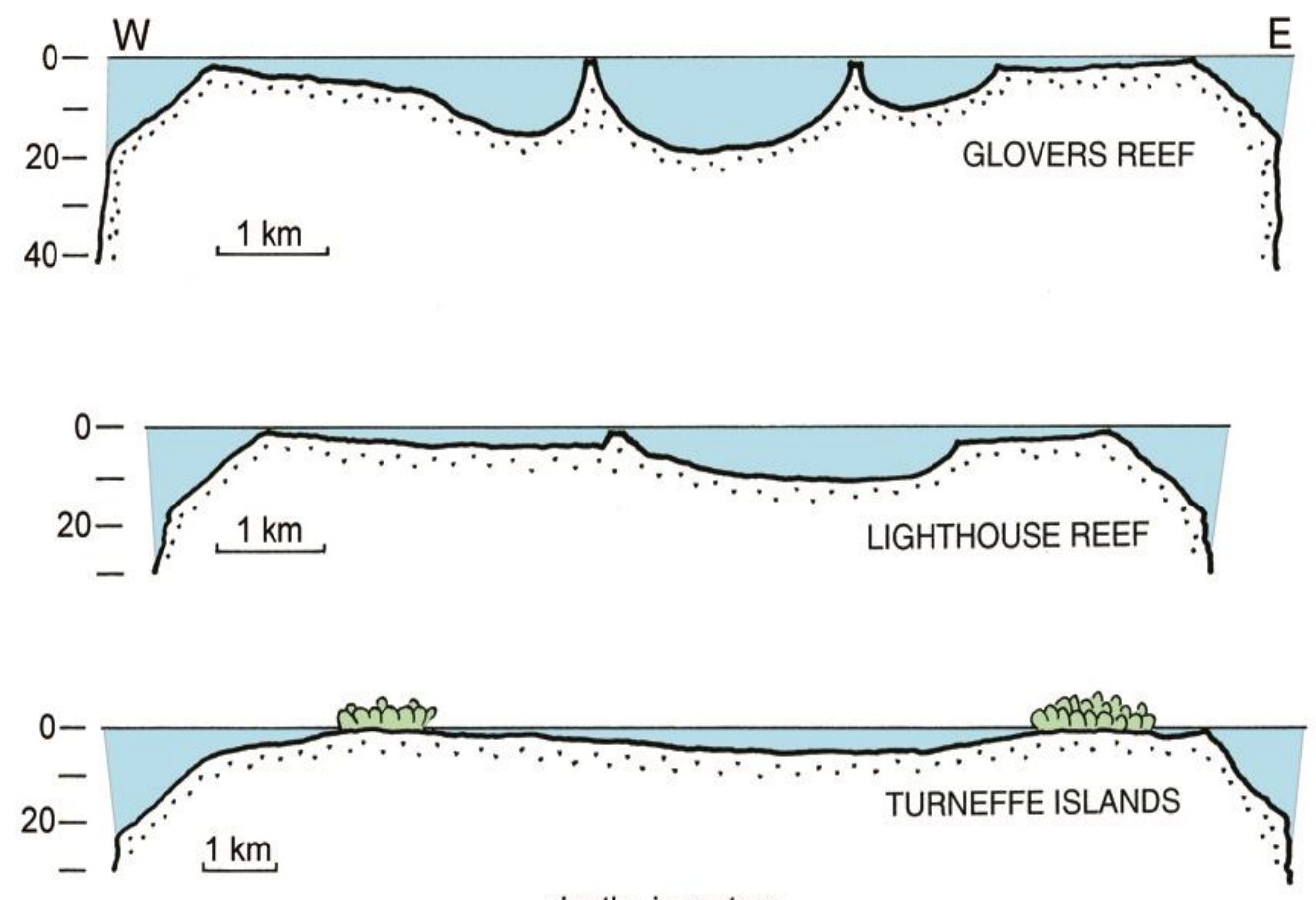

depths in meters

Figure 3. Cross-sections of the Belize atolls, including modern sediment facies as mapped by Gischler (1994) and Gischler and Lomando (1999).

patch reefs are found in the deep Glovers lagoon. In the northwestern lagoon, many of them are also arranged in NNE-trending chains.

Detailed observations on atoll island geomorphology, flora and fauna, composition of surface sediments, beachrock occurrence, and cay development make up a major part of Stoddart's work (Figure 5). Stoddart (1962a) distinguished between sand cays and mangrove cays. The formation of sand cays and sand-shingle cays is largely controlled by the action of refracted waves on gaps and bends of the reef. He also stressed in this context the importance of the relatively low tidal range in Belize $(\sim 0.3 \mathrm{~m})$, which results in low erosion rates as compared to macrotidal ranges such as the Queensland shelf.

Mangrove cays form due to the stabilizing and sediment-trapping effect of the red mangrove Rhizophora on shoals. The origin of mangrove-sand cays is debated and it is speculated that sand ridge and mangrove vegetation form as a single unit, rather than sequentially. As an explanation for the abundance of mangrove cays in the northern two atolls, Stoddart (1962a) suggests local uplift ("warping"). For Turneffe, he speculated whether many of the cays are located over karst-eroded elevations of the Pleistocene. Later core studies have revealed that Pleistocene elevation is indeed high below the reefs of Turneffe Islands, especially at the eastern margin of the platform where the Holocene deposits are only 2.8-3.3 m thick (Gischler and Hudson, 1998). In a subsequent paper, Stoddart (1965b) proposed a model of reef island formation based on his observations offshore Belize over six different energy environments from maximum energy (hardly any cays), sub-maximum energy (windward sides of Glovers, Lighthouse, southern barrier reef), high energy (windward side of Turneffe), medium energy (central barrier reef), to low or moderate energy (mangrove cays of Turneffe, central barrier reef). In an analysis of the land flora of the Belize cays, Stoddart and Fosberg (1982) recognized a correlation between reef island size and plant biodiversity. 


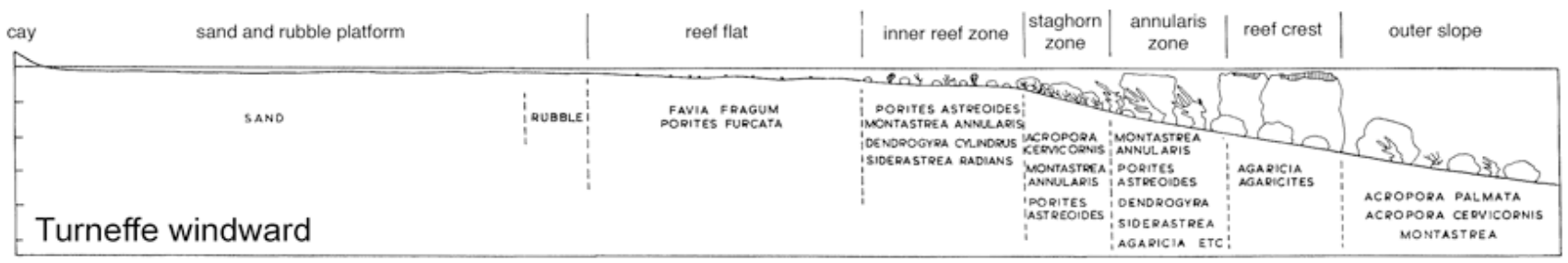

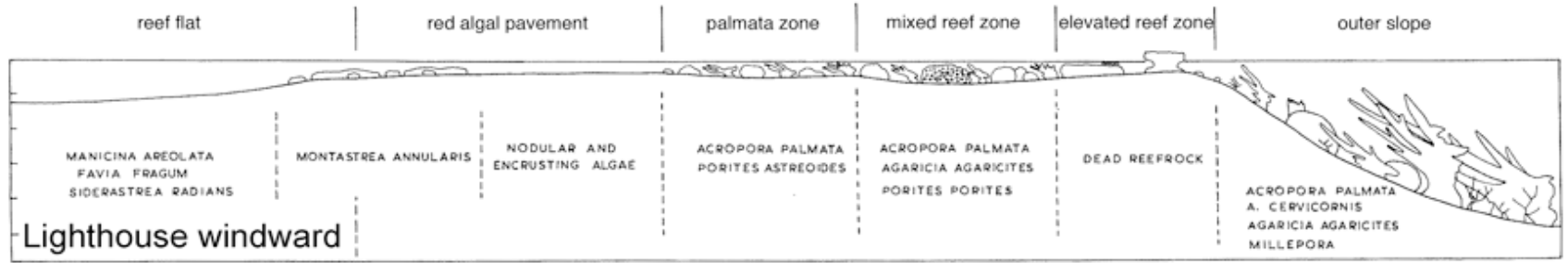

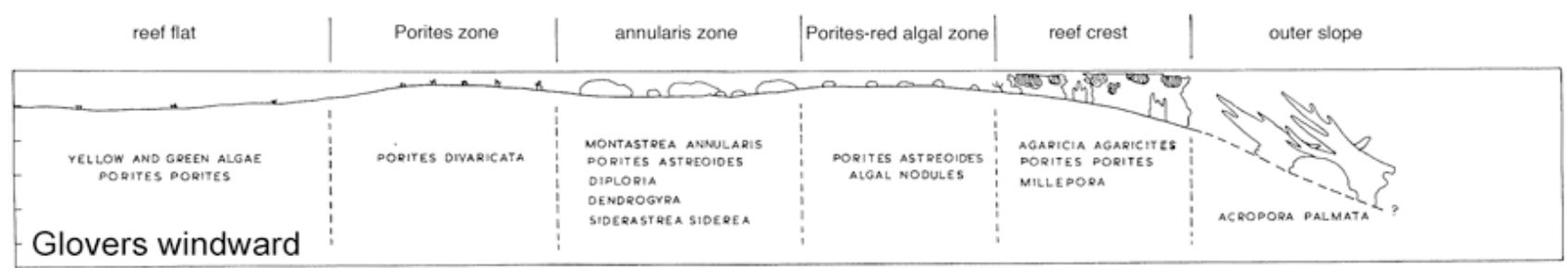

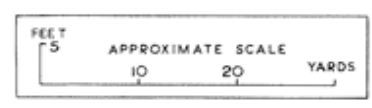

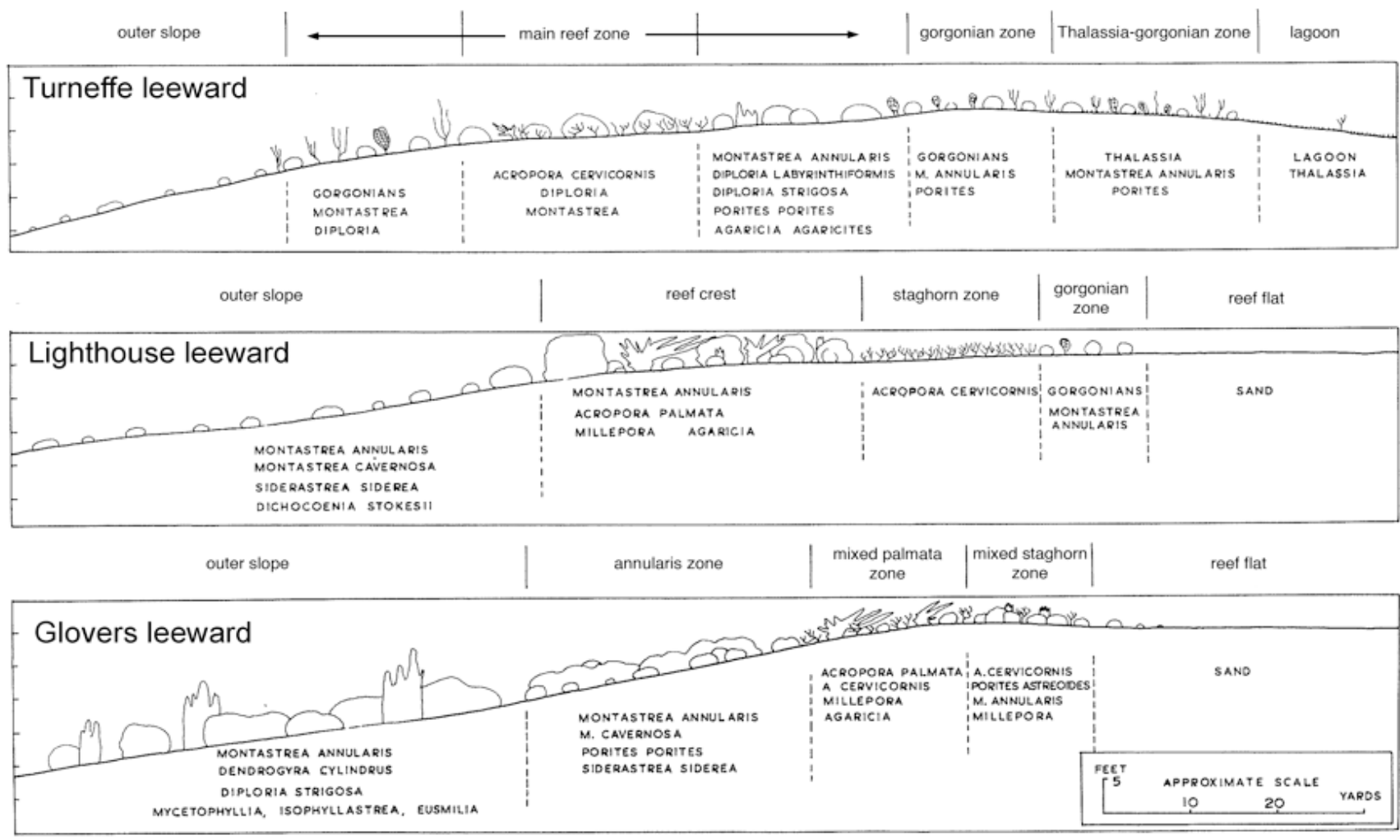

Figure 4. Marginal windward and leeward reef cross-sections of the Belize atolls; from Stoddart (1962a, modified). 

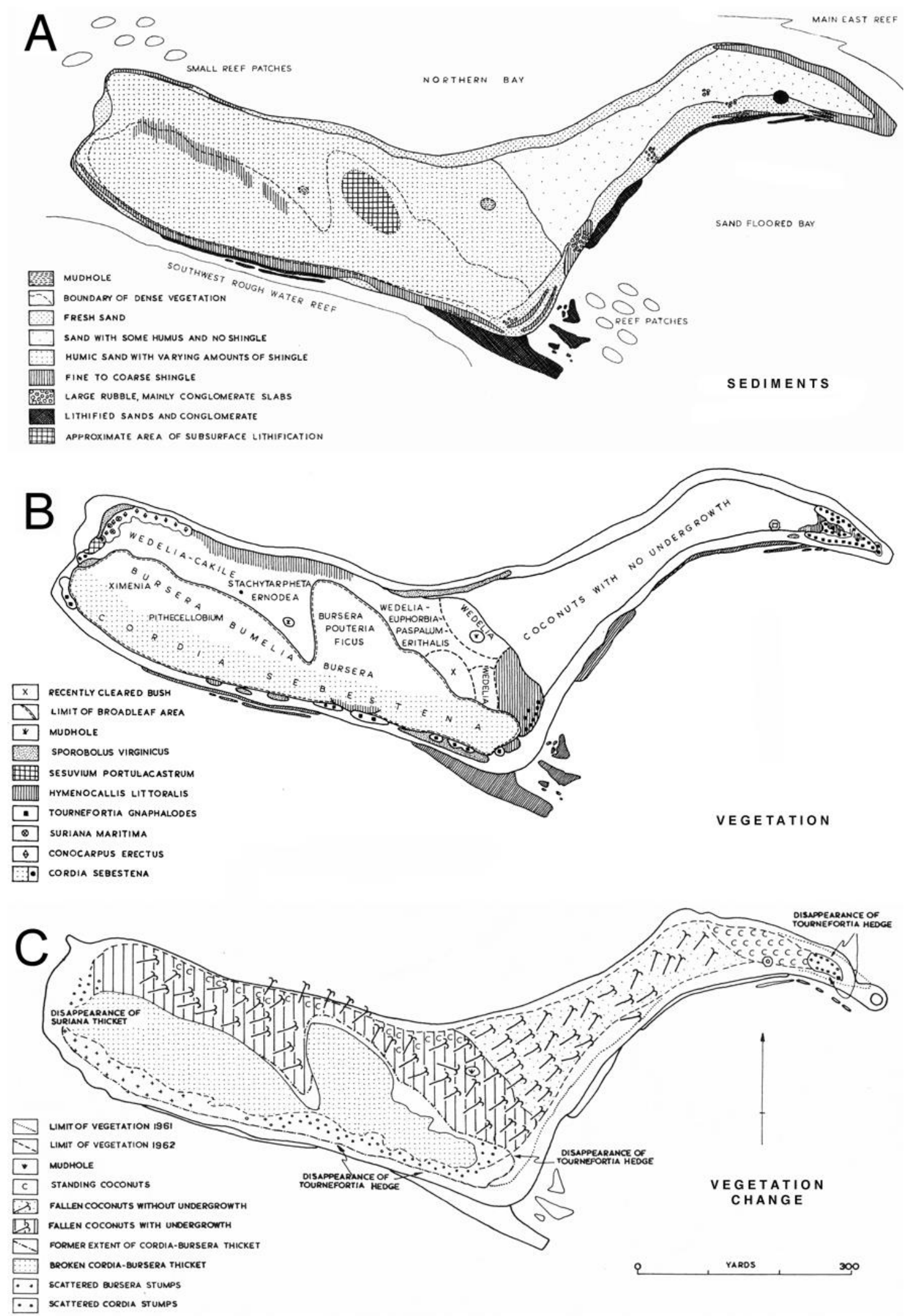

Figure 5. Maps of Halfmoon Cay, Lighthouse Reef, including (A) sediments, (B) vegetation, and (C) vegetation after Hurricane Hattie (from Stoddart, 1962a, 1963, modified). 


\section{Storm Impacts on Reefs and Reef Islands}

The impact of storms on the Belize reefs and cays is only briefly touched by Stoddart (1962a), but in great detail in subsequent publications. Because he had collected data before and after the landfall of the major Hurricane Hattie in late October 1961, Stoddart (1962b, 1963, 1965c) was able to directly assess the geomorphological and biological changes on reefs and reef islands due to the cyclone and the subsequent recovery. Hattie was a category 5 storm with sustained wind speeds of some $250 \mathrm{~km} / \mathrm{h}$ and measured peak winds of $>320 \mathrm{~km} / \mathrm{h}$. The storm passed right over the two northern Belize atolls and the central Belize Barrier Reef. Storm damage to the reefs was quite variable and apparently greatest along the central barrier reef (Figure 6). Physiographic and vegetation damage such as mangrove defoliation and coconut palm destruction was greatest on Turneffe Islands and Lighthouse Reef. Numerous of the smaller sand cays on the two atolls were washed away completely or large parts severely eroded. In a monograph, the physiographic changes are nicely illustrated in numerous pre- and post-storm line drawings of reef islands (Figure 5C). A re-survey in 1965 showed only minor geomorphologic adjustment, and reef recovery was estimated as having been small (Stoddart, 1965c, 1969). Vegetation recovery on sand cays had been considerable whereas mangrove cay damage around the storm track had been permanent (Stoddart, 1965c, 1969). A second re-survey in 1972 showed a general regrowth of the cay vegetation, however, heavily damaged mangrove areas still had not recovered. Erosion and considerable changes in outline of cays in reef-damaged areas, and minimal reef recovery in zones of great coral damage was visible (Stoddart, 1974).

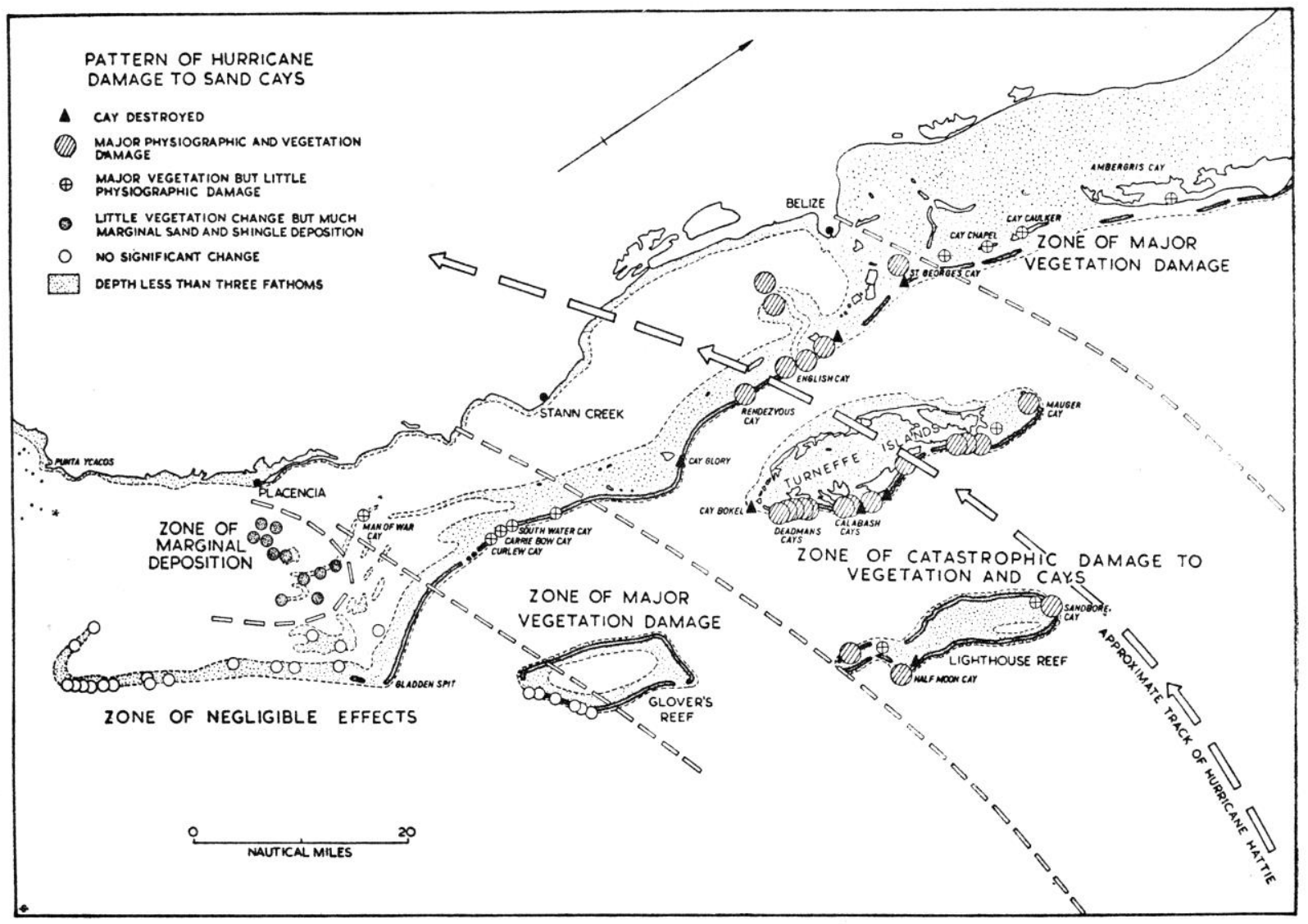

Figure 6. Storm effects on the Belize reefs and reef islands during Hurricane Hattie in late October 1961 (Stoddart, 1962b). 


\section{Reef Sediments, Beachrock, and Cay Sandstone}

Stoddart did not investigate marine sediments on the three Belize atolls. He did, however, analyze sediment composition and texture from some reef islands in great detail (Stoddart, 1962a, 1964). Plates from Halimeda, coral and red coralline algal fragments were identified as most common sediment constituents. The sediment study of Halfmoon Cay (Lighthouse Reef) is based on the analysis of 155 samples. Stoddart (1964) distinguished between beach sands, beach shingle, interior sands, dune sands, hurricane deposits, and underwater sands collected around the island. However, Stoddart (1964) conceded that size distribution and sorting of sediments are controlled by organic composition (grain type and texture) rather than by transport (wind and wave) energy. Together with the study by Folk and Robles (1964) on Isla Perez (Alacran Reef), this work represents a classic on reef island sediments.

Stoddart (1962b) also mapped and collected beachrock and cayrock from numerous islands of the Belize atolls and the barrier reef. Stoddart and Cann (1965) investigated beachrock samples from Halfmoon Cay (Lighthouse Reef; Figure 5) petrographically and found micrite envelopes and aragonite cement. They concluded that beachrock was cemented by marine waters and cited comparable results like the classic study by Ginsburg (1953) on beachrock on the Dry Tortugas (Florida). It is also interesting to note that Stoddart (1965c) noted incipient lithification of beachrock and cay sandstone within four years after the landfall of Hurricane Hattie. The cay sandstone occurrences were mostly in the spray zone according to Stoddart (1965c), which would suggest marine cementation. This was later confirmed in part by Gischler and Lomando (1997). On the other hand, Stoddart (1962a) had used occurrences of cemented beach deposits above the mean water level ("raised beachrock") as evidence for local uplift, e.g., outcrops at Harry Jones Point (eastern margin of Turneffe Islands) or Northern Cay (Lighthouse Reef). It turned out later, that the large majority of these occurrences were cayrock, which had been cemented by lowmagnesium calcite or organic "cement" in the meteoric zone (Gischler and Lomando, 1997).

\section{Reef Development}

At the end of his monograph, Stoddart (1962a) discussed the origin and development of the three Belize atolls. Because he could not call on core or other subsurface data, he speculated that the underlying Pleistocene surface probably had different elevations, i.e., highest in Turneffe and lowest in Glovers. Later core studies indeed proved that Pleistocene elevation is highest under the reefs of Turneffe Islands (2.8-3.3 m), lowest under the reefs of Glovers Reef (7.5-12 m), while elevation at Lighthouse Reef (6.5$8 \mathrm{~m}$ ) is intermediate (Gischler, 2003, 2007a, 2008; Gischler and Hudson, 1998, 2004; Gischler and Lomando, 2000; Gischler et al., 2000). In a statistical analysis of the shape of the world's atolls, which also included the Belize data, Stoddart (1965a) underlined the fact that atoll outlines are principally homogeneous, but in many cases differ from circular or near-circular shapes. Deviations from roundish shapes such as concave or scalloped patterns have repeatedly been interpreted as the expression of submarine slope failures (Fairbridge, 1950; Mullins and Hine, 1989; Terry and Goff, 2012). Stoddart (1962a) actually speculated about the origin of the large concave bights at the southeastern and southwestern margins of Lighthouse Reef as being the consequence of slope failure. In his review of Quaternary reef development, Stoddart (1973) referred to subsurface data of Purdy (1974, a, b) from the Belize Barrier Reef to underline the accretion potential of Holocene reefs $(1.1-7.8 \mathrm{~m} / \mathrm{kyr})$ and to stress the importance of antecedent topography.

\section{RESEARCH TOPICS ON THE BELIZE ATOLLS FOLLOWING DAVID STODDART'S WORK}

\section{Geomorphology}

Knowledge of the bathymetry of the Belize atolls was expanded significantly in the fore reef areas by the work of James and Ginsburg (1979). They conducted submersible dives to water depths 26 
exceeding $300 \mathrm{~m}$ along the central and southern barrier reef and on the leeward and windward sides of Glovers Reef. The seaward slope of Glovers Reef drops of at water depths 20-50 m and transitions into an almost vertical wall. On the western side of Glovers Reef, a talus slope was encountered below the wall in $\sim 100 \mathrm{~m}$ depth; on the windward side, the fore reef remains close to vertical to water depths exceeding $310 \mathrm{~m}$. Gischler (1994) and Gischler and Lomando (1999) refined the bathymetry of atoll interiors during the collection of hundreds of surface sediments. As mentioned above, the maximum depth of the Glovers lagoon as reported by Stoddart (1962a) was too high. Recently, Shcherbina et al. (2008) used an autonomous underwater vehicle to map the shallow fore reef areas surrounding Glovers Reef indetail. Interestingly, they documented a $\sim 1 \mathrm{~km}$ wide, up to $25 \mathrm{~m}$ deep shelf-like extension of the fore reef on the NE margin of the atoll.

The fact that most of Turneffe Island lagoons are characterized by restricted circulation and a lack of lagoon reefs, whereas the northern part has open circulation and lagoon reefs suggests that exposure to waves and currents is an important factor of reef development (Gischler and Hudson, 1998). Expansive mangrove islands apparently only developed in those platform parts that are protected to the east by Lighthouse Reef whereas in the unprotected, northernmost part an open lagoon has developed (Figure 7).

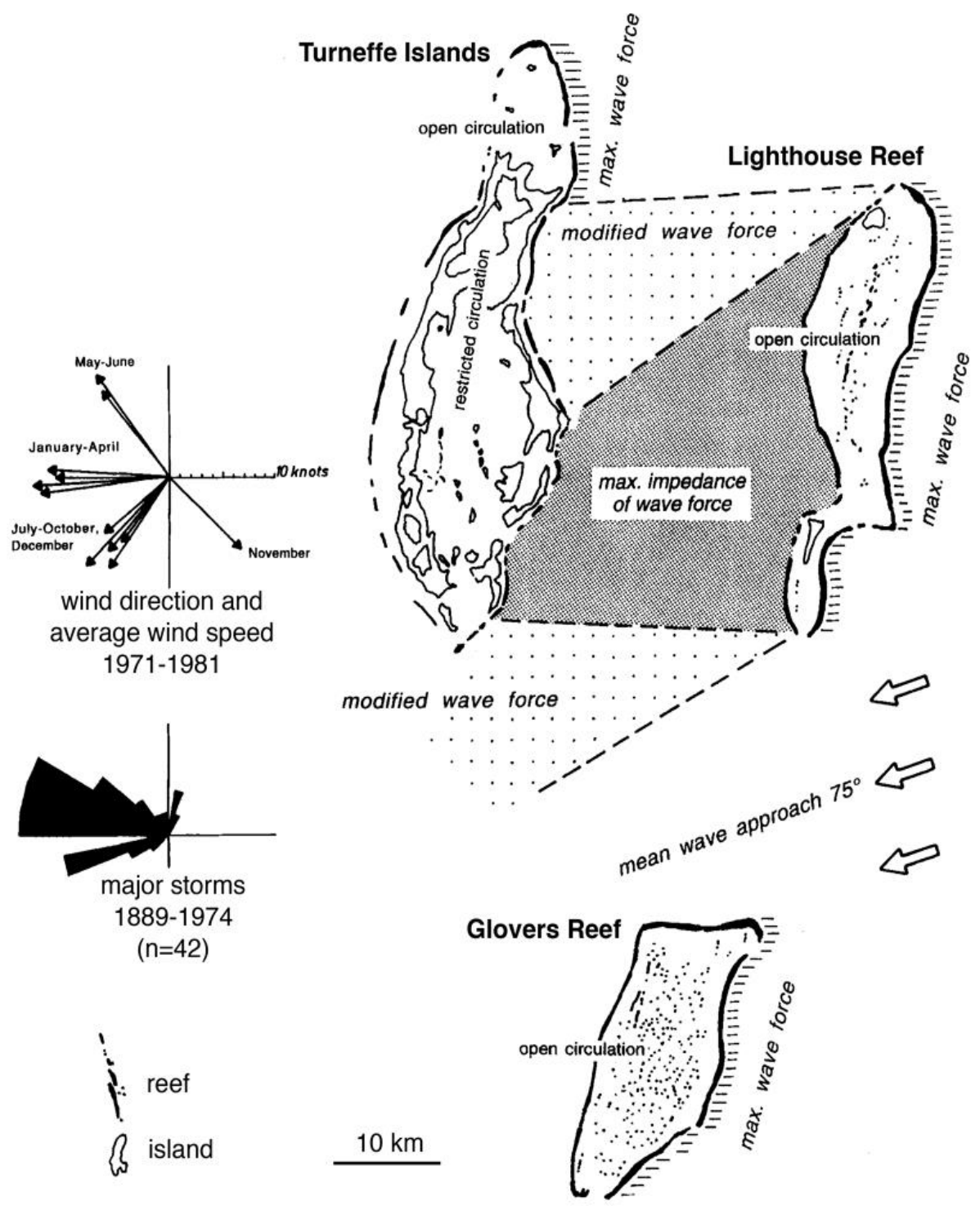

Figure 7. Influence of exposure to waves and currents to the Belize atolls (from Gischler and Hudson, 1998). 


\section{Reef Sediments}

James and Ginsburg (1979) collected numerous surface sediment samples in the shallow and deep fore reef areas of Glovers Reef. Shallow fore reef sediment consists of abundant coral fragments and Halimeda plates, together with fragments of coralline algae, mollusk shells, echinoid spines, and test fragments of the encrusting foraminifer Homotrema. The amount of fines is $<10 \%$; significant amounts of fines were found only some $2 \mathrm{~km}$ away from the reef wall. Gischler (1994) and Gischler and Lomando (1999) systematically sampled and analyzed surface sediments $(n=266)$ of the Belize atolls (Figure 8), including Banco Chinchorro (Mexico), located some $110 \mathrm{~km}$ NNE of Turneffe Islands. These data together with those of Purdy (1974a) from the Belize shelf were used to compile a sediment map of the entire Belize reef margin (Purdy and Gischler, 2003).

For the atolls, Gischler and Lomando (1999) defined four facies including coral-red algalHalimeda grainstone at platform margins and lagoon reefs, mixed non-skeletal (peloidal) wackestonepackstone in shallow lagoon areas, mollusk-foram-Halimeda wackestone in deep lagoon areas, and Halimeda-rich wackestone in the Turneffe lagoon. Grain-supported textures are more common in shallow depths whereas mud-supported textures predominate in greater depths. However, there is considerable bathymetric overlap of facies, especially in intermediate depths (Figure 9). Such limitations in the faciesdepth relationship in shallow depths have also been found in other carbonate platform systems (Purkis et al., 2015). Whereas facies belts are more or less circular in Glovers and Turneffe lagoons, they are linearly oriented in the Lighthouse lagoon. Rhodoliths are a common component of the windward reef facies of Glovers and Lighthouse Reefs and the unprotected northern margin of Turneffe Islands, underlining the significance of wave action for rhodolith formation (Gischler and Pisera, 1999).

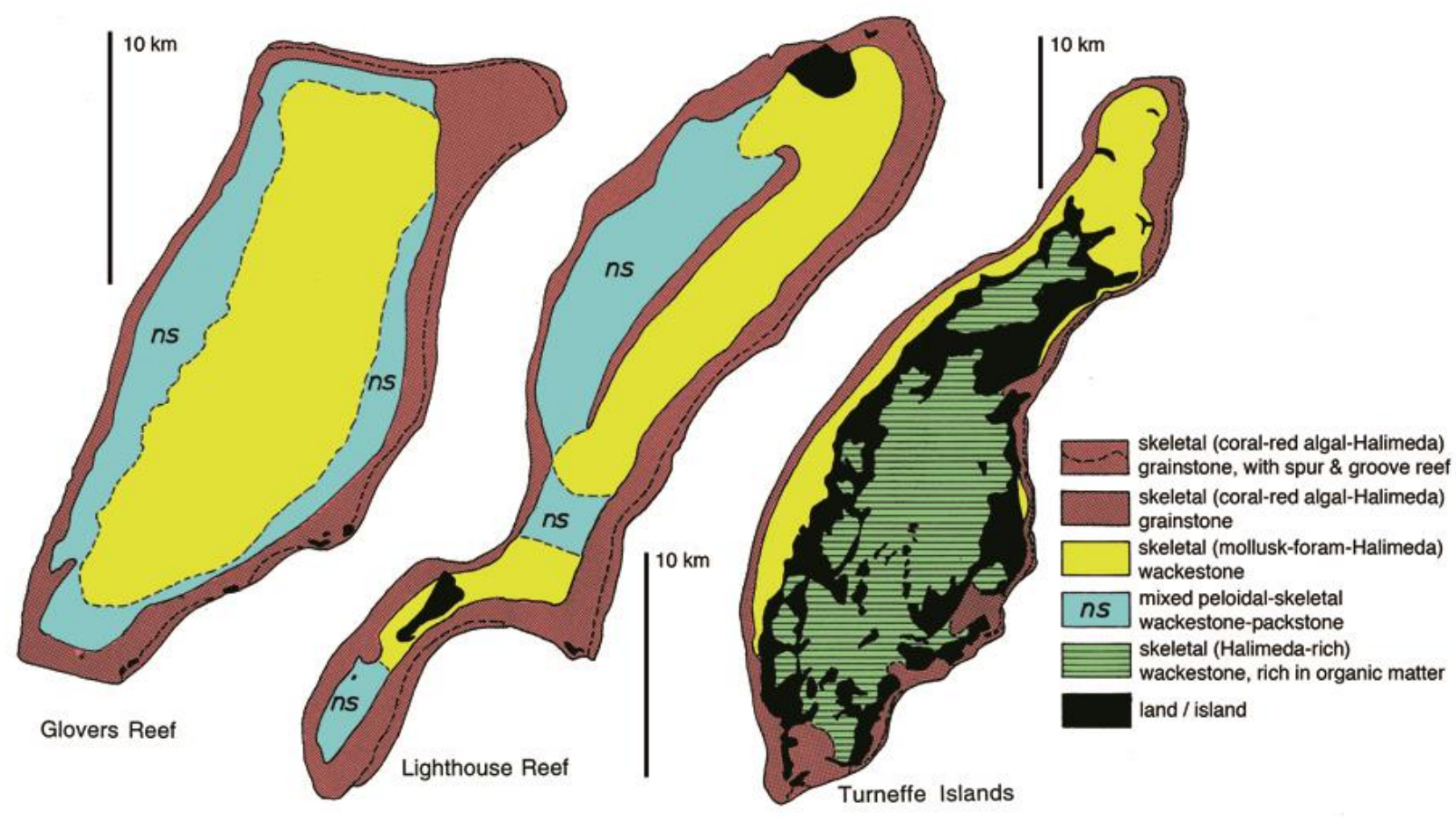

Figure 8. Sediment distribution on the Belize atolls based on the quantitative analysis of texture and composition of 266 samples (after Gischler and Lomando, 1999, 2000). 


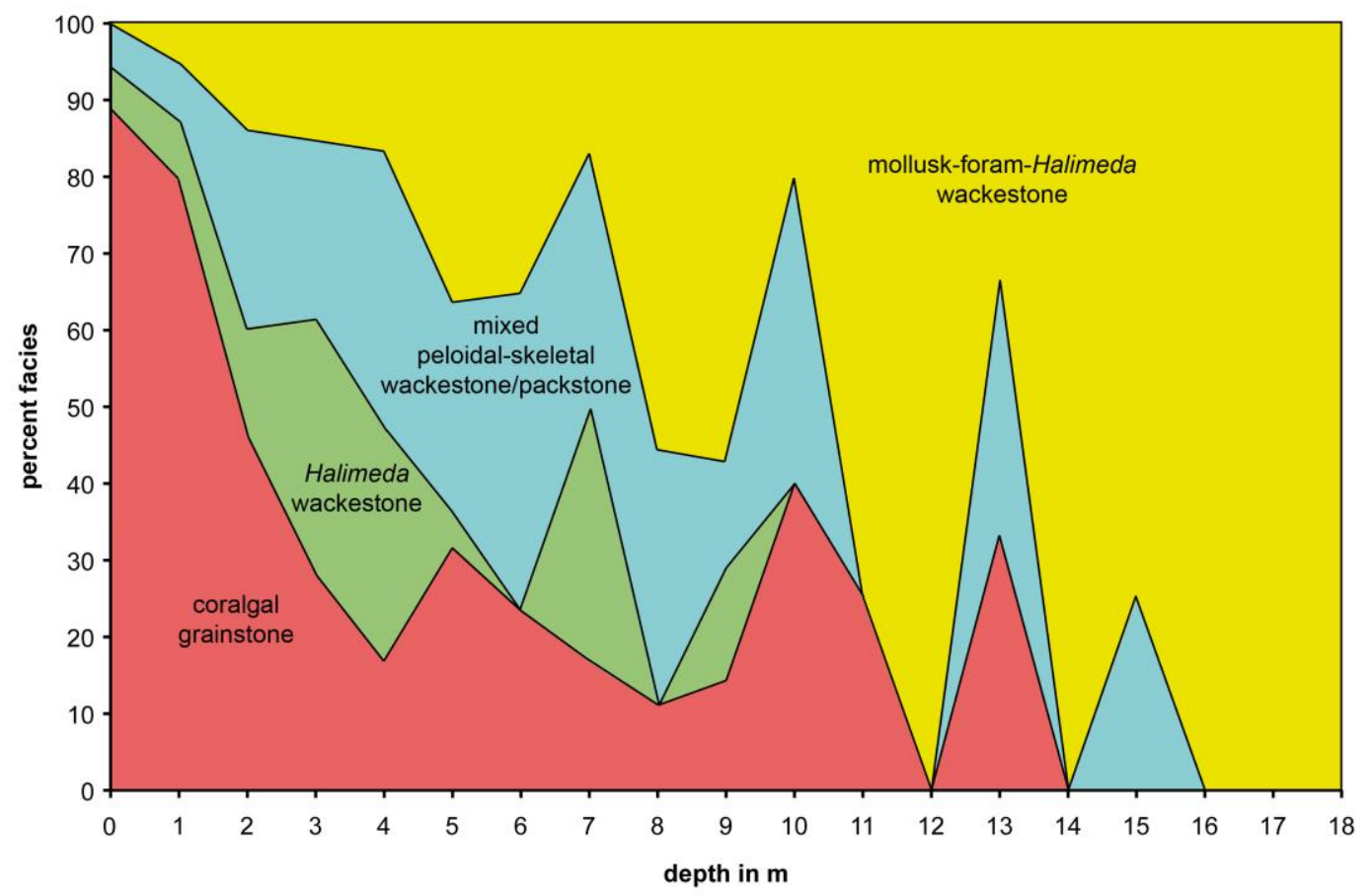

Figure 9. Depth distribution of facies shows significant overlap in intermediate depths. As a consequence, Shannon-Wiener evenness is high in shallow and large depth as opposed to intermediate depths.

\section{Reef Development}

The first subsurface data from the Belize atolls stems from two exploration wells of the oil industry drilled on Turneffe Islands and Glovers Reef during the early 1960s (Gischler and Lomando, 2000; Purdy et al., 2003). The Turneffe well (total depth $2134 \mathrm{~m}$ ) penetrated some $1030 \mathrm{~m}$ of Tertiary and Quaternary reefal and shallow-water limestones before reaching Eocene to early Cretaceous siliciclastics and volcanics. The Glovers well (total depth $959 \mathrm{~m}$ ) penetrated some $550 \mathrm{~m}$ of Tertiary reefal and shallow water limestones, underlain by late Cretaceous to Eocene siliciclastics and Paleozoic shales. The deep basement of the barrier and atoll reefs are NNE-trending fault-blocks along the Belize passive margin (James and Ginsburg, 1979; Purdy et al., 2003). The upper $\sim 100 \mathrm{~m}$ of the two exploration wells were not cored so that virtually no Quaternary deposits were recovered.

Based on shallow seismic data across the Belize shelf and barrier reef, Purdy (1974a) concluded that antecedent karst topography and underlying structural elements were decisive for Holocene sedimentation in that Pleistocene limestone was dissolved and structural elements such as faults served as dissolution patchways. Indeed, there are numerous examples of linear reefs on the Belize shelf and atolls, apparently expressing tectonic influence (e.g., linear patch reefs trends on Glovers Reef and Lighthouse Reef). In the Holocene, topographic highs acted as pedestals for reef accretion whereas lows were characterized by fine carbonate sediment accumulation. On the southern shelf, siliciclastics derived from the Maya Mountains underlie modern sediments. Karst relief apparently increases from north to south due to the increase in precipitation (and presumably paleo-precipitation) rates on the Belize shelf, reflecting mainland topography, according to Purdy (1974a, b). For ground-truth, Holocene thickness and nature of the underlying Pleistocene material was checked in eight rotary cores and numerous piston cores.

Subsequent shallow reef coring with portable drill rigs, including analysis of Holocene reef sections, was done on the central barrier reef area in the vicinity of the Smithsonian research Station of Carrie Bow Cay (Halley et al., 1977; Macintyre et al., 1981; Shinn et al., 1982). Deeper wells were drilled in northern Belize (Mazzullo, 2006) and on the southern barrier reef platform (Gischler et al., 2010). 
Macintyre et al. $(1995,2000,2004)$ reconstructed the Holocene formation of various mangrovedominated islands on the barrier reef platform based on shallow vibracoring. Seismics were used in a number of studies to analyze the subsurface of the Belize shelf (Choi and Ginsburg, 1982; Choi and Holmes, 1982; Lara, 1996; Esker et al., 1998; Ferro et al., 1999).

Shallow reef coring on the Belize atolls began in the mid-1990s. Gischler and Hudson (1998) and Gischler and Lomando (2000) recovered 14 cores from the reefs of the three atolls (Figure 10). Holocene reef thickness was highest on Glovers Reef $(11.5 \mathrm{~m})$, reached $8.5 \mathrm{~m}$ on Lighthouse Reef, and $3.3 \mathrm{~m}$ on Turneffe Islands. Such a result was indirectly predicted by Stoddart (1962a). Acropora palmata and Orbicella sp. were the most commonly recovered corals. In addition, Diploria sp., Colpophyllia sp., Agaricia sp., A. cervicornis, and Millepora sp. were common. Millimeter to centimeter thick crusts of microbialite were observed in lower core sections (Gischler, 2008; Heindel et al. 2012). Holocene reef growth began as early as 7.78 kyrs BP on Glovers, 7.48 kyrs BP on Lighthouse, and 5.0 kyrs BP on Turneffe (oldest obtained dates). Holocene reef accretion rate decreases during the Holocene; the average accretion rate in the Belize atoll and barrier reefs amounts to $3.03 \mathrm{~m} / \mathrm{yr}$ (Gischler, 2008). The decrease in reef accretion during the Holocene could be a consequence both of the slowing rate of sea-level rise, i.e., shrinking accommodation space and be influenced by climatic cooling following the Holocene Climate Optimum (Marcott et al. 2013).

A total of 32 vibracores were collected in the Belize atoll lagoons (Gischler, 2003). Ideal successions contained a basal terrestrial soil, followed by mangrove peat, overlain by mollusk shell-rich carbonate sediment that exhibits upward fining (Figure 11).
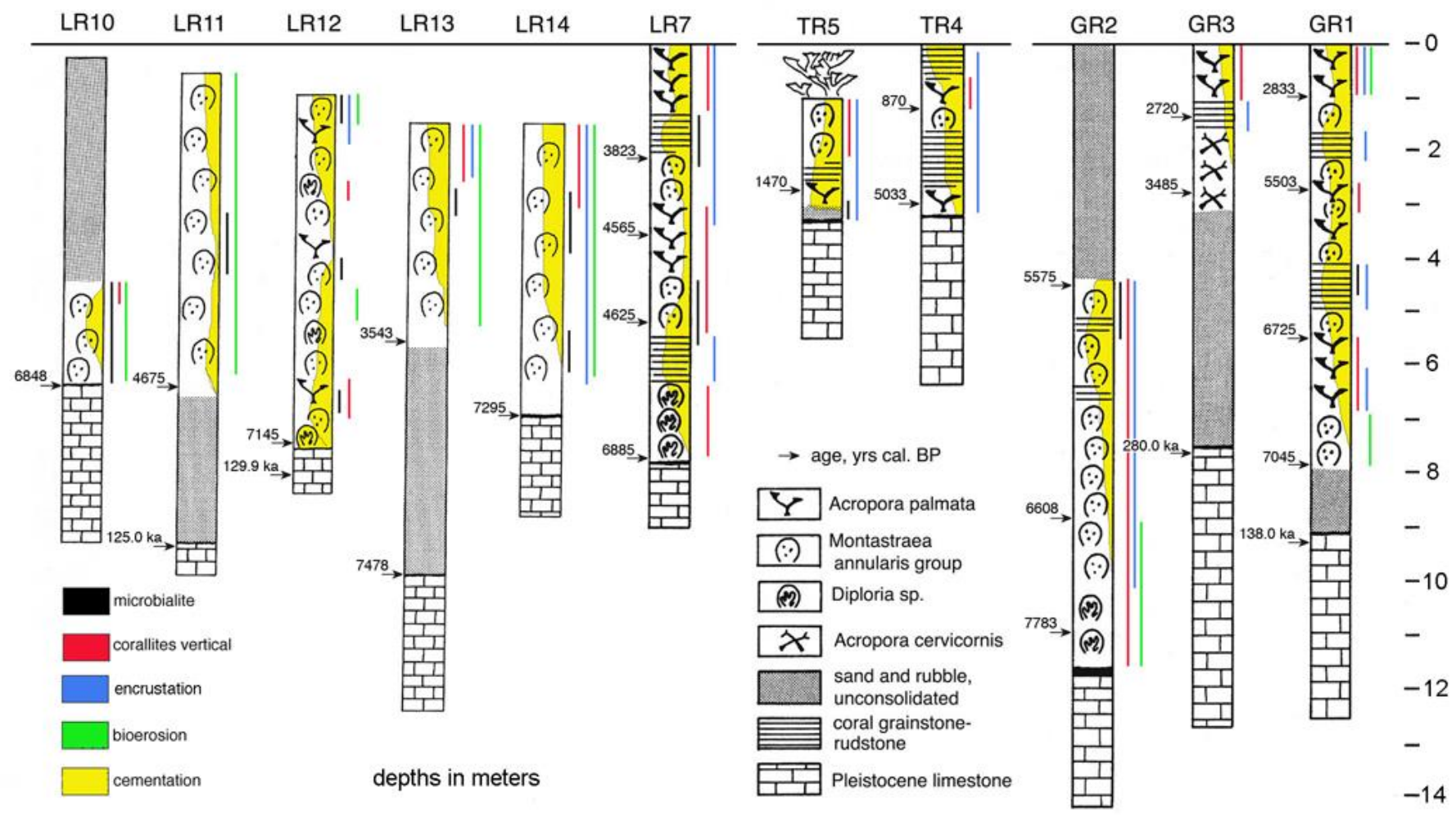

Figure 10. Selected reef cores from the three Belize atolls including age data (from Gischler, 2008). Holes 6, 8, and 9 are not shown as they had virtually no Holocene recovery (Gischler and Hudson, 1998). For location of holes, see Figure 11D. 
A

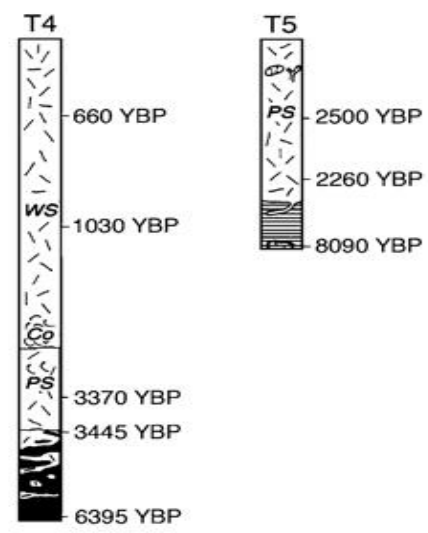

C
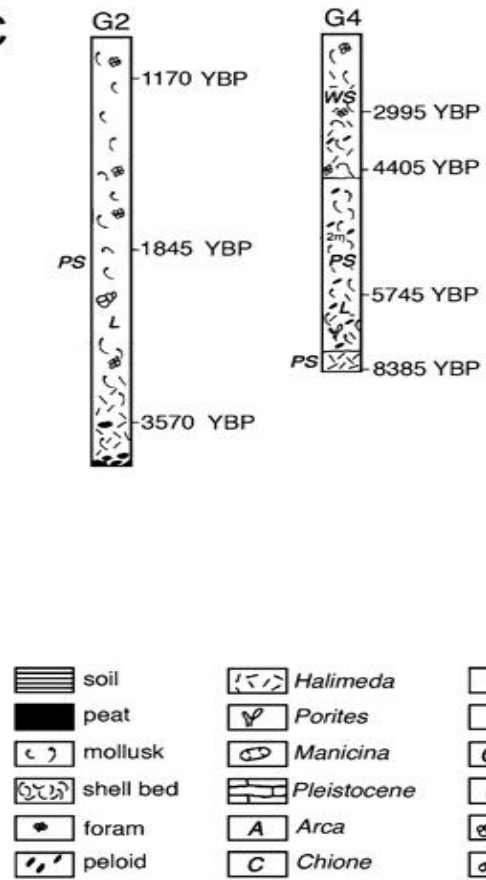
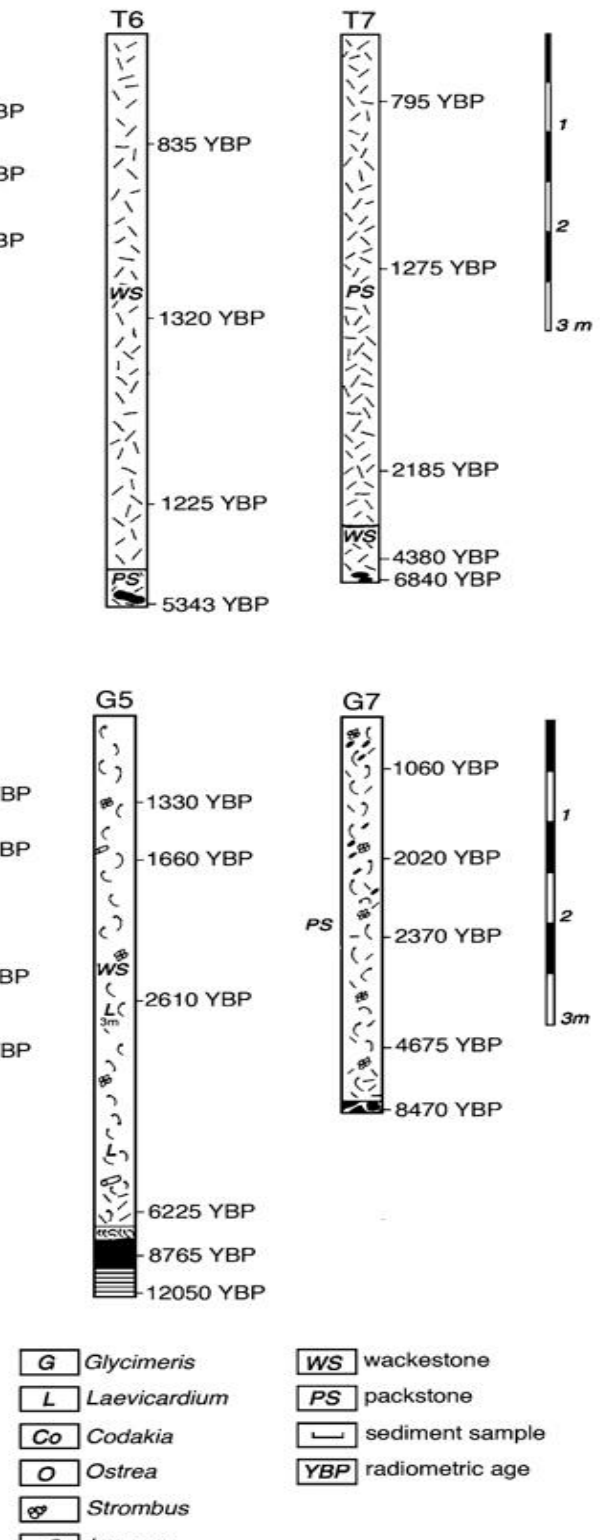

B
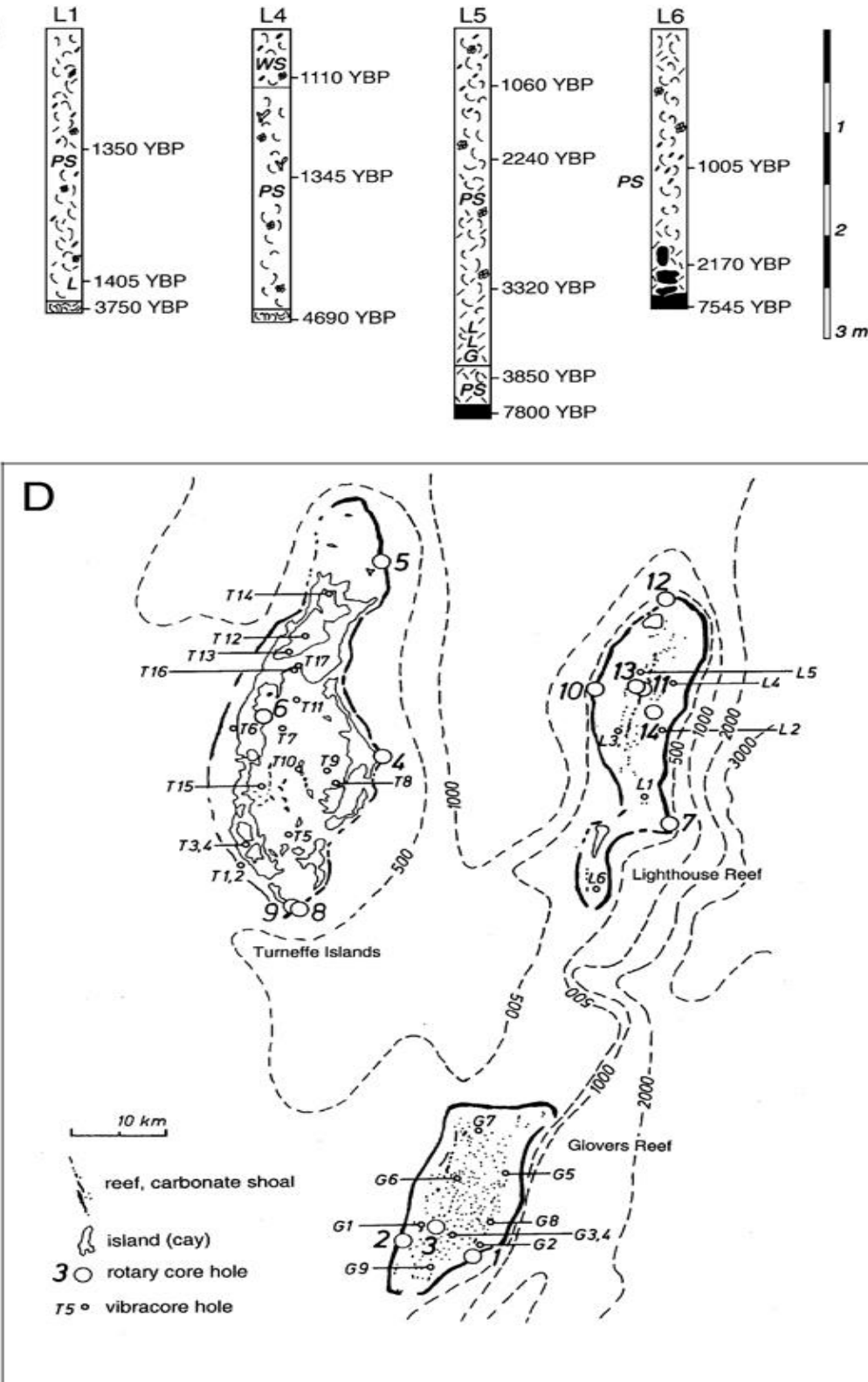

Figure 11. Selected lagoon cores from Turneffe Islands (A), Lighthouse Reef (B), and Glovers Reef (C). Modified from Schultz et al. (2010). D. Locations of rotary core and vibracore holes on the Belize atolls (from Gischler, 2003). 
There is usually a considerable hiatus of up to 2 kyrs between the mangrove peat and the basal carbonates, indicating that there was a time lag before carbonate-producing organisms could establish themselves after initial marine inundation, which probably included turbid, nutrient-rich waters with fluctuating temperature and salinity. Holocene lagoonal carbonate sediments have packstone and wackestone textures and get up to $5.7 \mathrm{~m}$ thick. The oldest basal peat ages are $8.77 \mathrm{kyrs}$ BP on Glovers, 7.8 kyrs BP on Lighthouse, and 6.84 kyrs BP on Turneffe. The oldest lagoonal carbonate ages are 6.23 kyrs BP on Glovers, 4.69 kyrs BP on Lighthouse, and 4.38 kyrs BP on Turneffe (Gischler, 2003; Schultz et al., 2010). In the case of Turneffe Islands, sandwich-type, peat-carbonate-peat successions in cores are found occasionally under mangrove islands (Gischler, 2003). McCloskey and Liu (2013) interpreted the carbonate inter-layers as caused by peat collapse rather than by events such as storms. Sedimentation rate in the Belize atoll lagoons has increased slightly during the Holocene; average sedimentation rate is 1.35 $\mathrm{m} / \mathrm{kyr}$, i.e. about a third of average reefal accretion rate. This difference certainly promotes the formation of so called empty-bucket geomorphology over time that is typical for Quaternary atoll reefs (Purdy and Gischler, 2005, and references therein). Reef rotary core and lagoon vibracore data allows the reconstruction of platform development during the Holocene including sequential flooding of late Pleistocene carbonate islands resulting in three geomorphologically different atolls (Figure 12).

Both Holocene atoll reefs and lagoon deposits are underlain by well-consolidated Pleistocene limestone. Five reefal and lagoonal facies were delineated from the sections recovered at core bases (Gischler, 2007a). U-series ages of Pleistocene deposits usually fall in the last interglacial highstand of marine isotope stage 5e, some 135-115 kyrs BP (Gischler et al., 2000). However, U-series and amino acid razemization age data also indicate the presence of pre- and post-MIS5e deposits deposited during previous Pleistocene sea-level highstands (Gischler et al., 2000; Gischler, 2007a; van Ee et al., 2012; van Ee, 2013).

Based on the elevation and age of Pleistocene limestone underlying the Holocene reefs in Belize it is possible to estimate subsidence rates of the atolls and the adjacent barrier reef. Subsidence increases range from $0.04-0.12 \mathrm{~m} / \mathrm{kyr}$ and increase in southward direction along individual fault-blocks (Gischler et al., 2000; Gischler and Hudson, 2004). The observed southward decrease in Pleistocene elevation is presumably enhanced by increased meteoric dissolution in the same direction due to spatial variation in paleo-precipitation (Figure13).

New seismic and rotary core data from Glovers Reef shows that the Pleistocene surface under the Holocene reefs and sediments is rather flat but has a karst relief (van Ee, 2013). The large majority (ca. 90\%) of lagoonal patch reefs are located over Pleistocene topographic highs, as shown by Purdy (1974a) for the Belize shelf and barrier reef. Whether or not the highs are strictly growth-induced (patch reef) is not entirely clear. Apart from subsidence and antecedent karst topography, the rise of sea level has controlled Holocene reef growth along the Belize margin because it controlled the creation of accommodation space, and hence, the style of reef and lagoon accretion.

\section{Marine Cementation and Beachrock}

In their work on the Belize barrier and atoll fore reef area, Ginsburg and James (1976) and James et al. (1976) also investigated carbonate diagenesis in samples broken-off from the reef surface. They described various aragonite and high-magnesium calcite cement types, and stressed the importance of microcrystalline and bladed high-magnesium calcite cements. Interestingly, cementation was only pervasive in the upper ca. $1 \mathrm{~m}$ of the reef. Below that depth, cementation was sparse and the reef limestone rather friable. Ginsburg and James (1976) also described the abundant occurrence of botryoidal aragonite cement in late Pleistocene/early Holocene deep fore reef limestone, which was later analyzed geochronologically by Grammer et al. (1993). It was possible to date bases and tops of cement crusts and to calculate cement growth rate in reefs for the first time, which amounted to $80-100 \mu \mathrm{m} / \mathrm{yr}$. A variety of marine high-magnesium calcite and aragonite cements were also found in cores penetrating the Holocene reefs of the Belize atolls and barrier reef (Gischler and Hudson, 1998, 2004). Reef cementation was also found to be more pervasive in the upper core sections. In three core holes on Glovers Reef, it was shown 

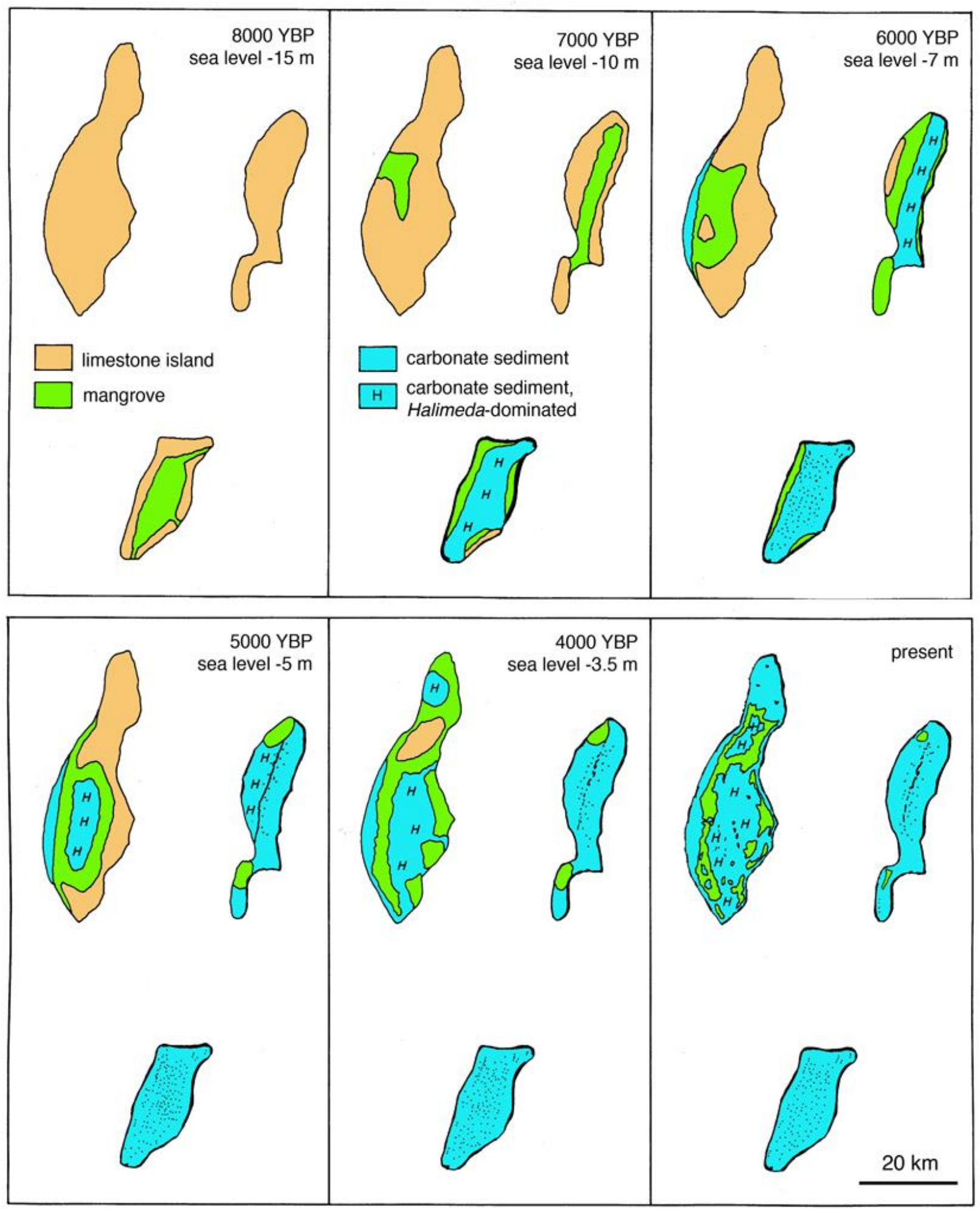

Figure 12. Holocene development of Belize atolls in six time slices during the Holocene (from Gischler, 2003, modified). 


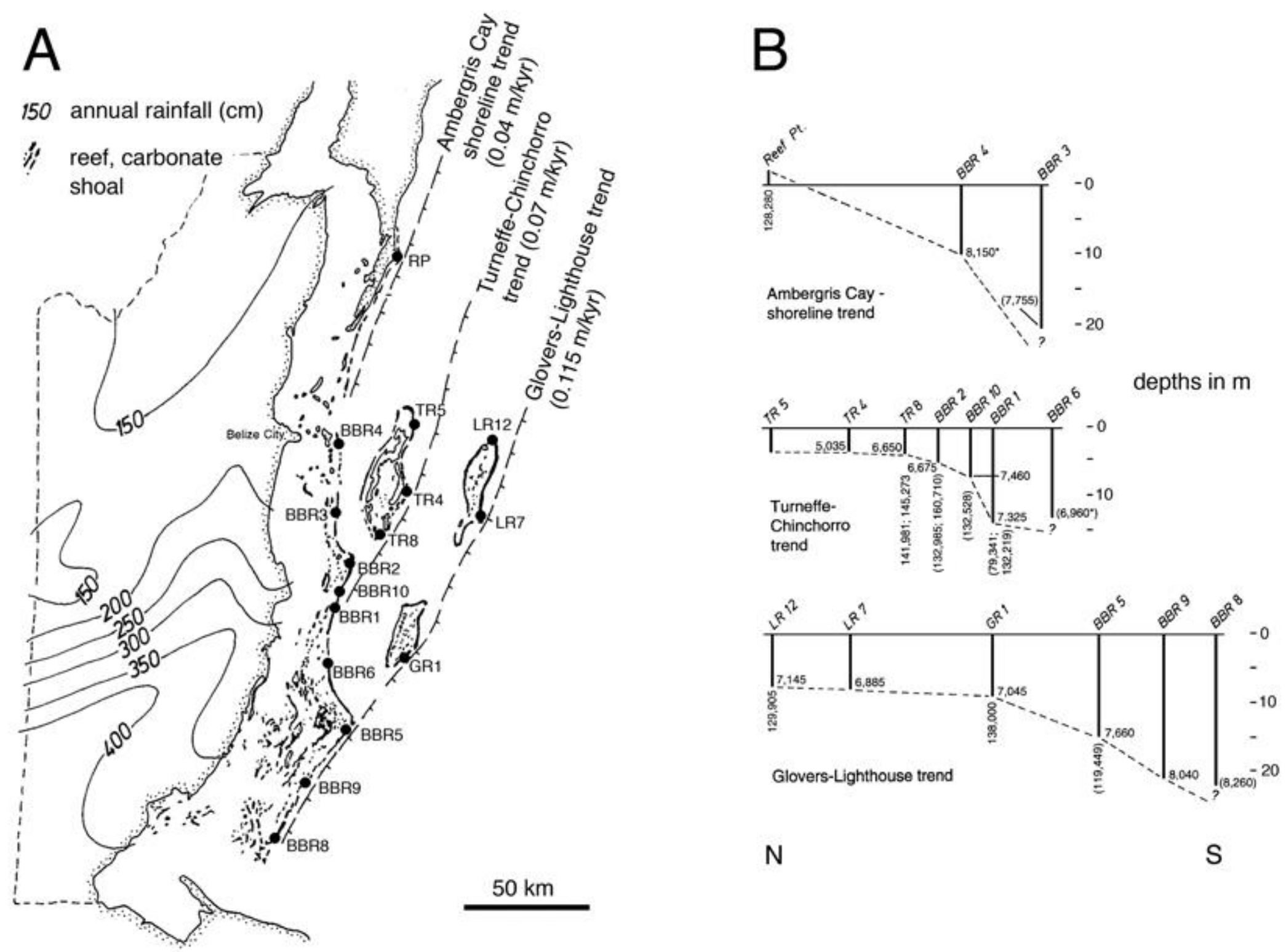

Figure 13. A. Increase of precipitation in Belize from north to south, including core hole stations on atolls and barrier reefs. B. Increase in subsidence along fault-blocks of the Belize margin (after Gischler et al., 2000; Gischler and Hudson, 2004). 


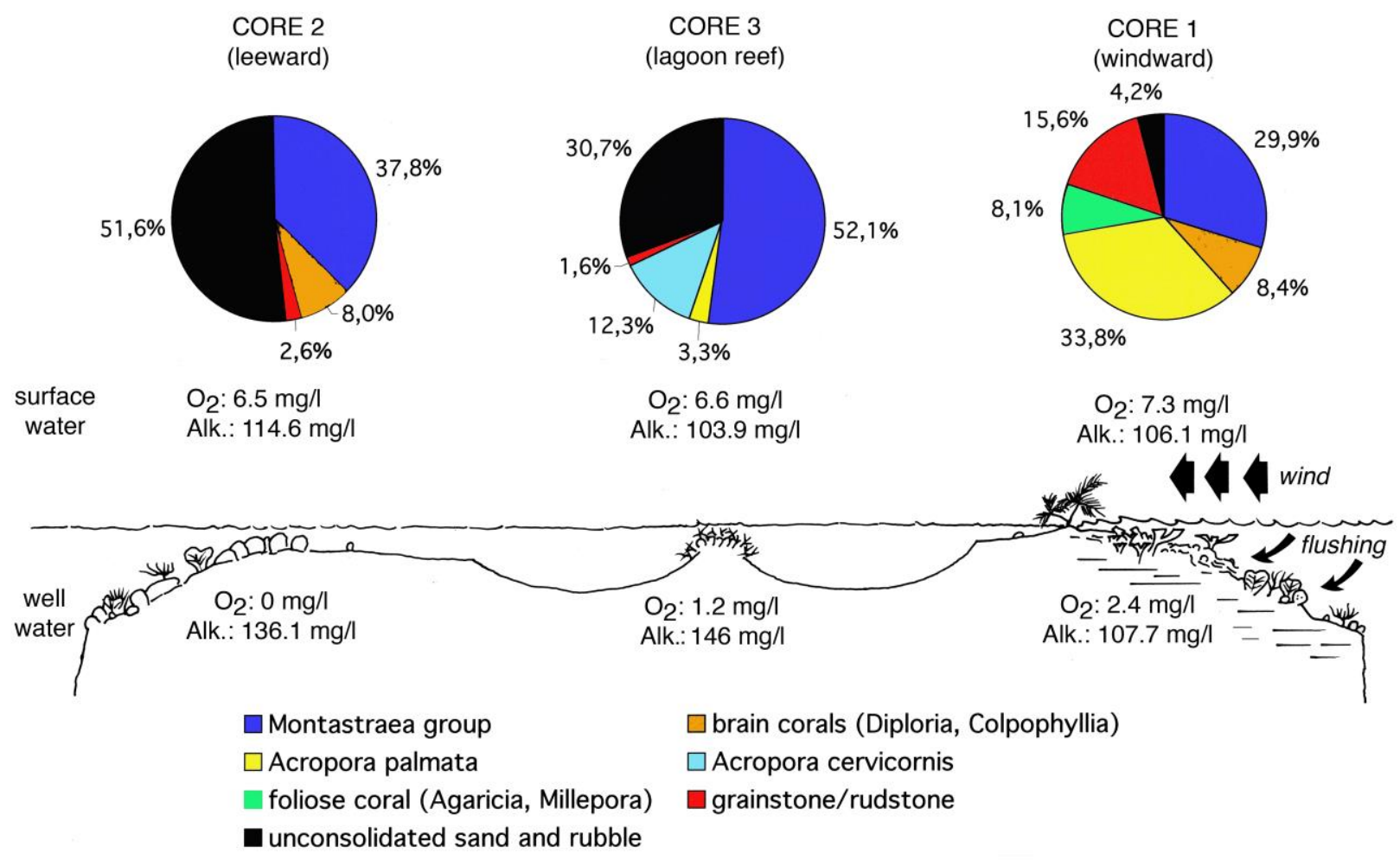

Figure 14. Schematic cross-section through Glovers Reef with three boreholes and average composition of cores. Note the amount of unconsolidated material increases from windward to leeward. Data on oxygen concentration $(\mathrm{mg} / \mathrm{l})$ and alkalinity $\left(\mathrm{mg} \mathrm{CaCO}_{3} / \mathrm{l}\right)$ from analysis of surface and well water samples (average values of 4 measurements each).

that reef consolidation decreased from the windward to the lagoon patch reef to the leeward cores. Core recovery decreased and the amount of unconsolidated material increased from windward to leeward, suggesting that energy and hence flushing the pore space with carbonate-saturated seawater is decisive for early marine cementation (Figure 14). The windward-to-leeward decrease in flushing was also established using dye injections into core holes and from water sampling from core holes that were modified into $3 \mathrm{~m}$ deep wells after drilling.

The significance of water agitation for marine cementation was also shown by the large-scale distribution of beachrock on reef islands in Belize including the offshore atolls (Gischler and Lomando, 1997; Gischler, 2007b). Abundant intertidal beachrock formation, i.e., early marine cementation, preferentially occurs on windward beaches of sand-shingle cays of Glovers Reef, Lighthouse Reef, and the southern barrier reef, where large amounts of seawater are steadily flushing the beach. In contrast, supratidal cayrock or cay sandstone, cemented in the vadose zone, was only preserved on larger, stable mangrove-sand cays. Petrographic analysis of the cemented material described by Stoddart (1962a) as elevated beachrock was in fact cayrock. The field-work for the study of Gischler and Lomando (1997) relied heavily on the detailed reef island maps provided by Stoddart $(1962 \mathrm{a}, 1963,1969)$.

\section{Sclerochronology, Paleoclimate, and Paleotempestology Studies}

The first sclerochronological study performed in the waters of Belize was made by Druffel (1980) who analyzed $\Delta^{14} \mathrm{C}$ variation along a core of a massive coral (Orbicella) collected on a lagoon patch reef of Glovers Reef. The results showed both the uptake of carbon dioxide from the combustion of carbohydrates (Suess effect) and of atomic bomb ${ }^{14} \mathrm{C}$. Gischler and Oschmann (2005) analyzed extension 
rate, $\delta^{18} \mathrm{O}$, and $\delta^{13} \mathrm{C}$ time series from Orbicella and Siderastrea cores taken in the Belize atolls and the central barrier reef. Correlations with instrumental climate data of temperature and salinity were moderate, however, a decadal periodicity (10-15 yrs) was detected and interpreted as caused by the Atlantic dipole variation. The analysis of $\delta^{18} \mathrm{O}$ and $\delta^{13} \mathrm{C}$ time series from fossil (Holocene) corals obtained in reef cores suggest that warmer and/or wetter conditions in the early-mid Holocene and the modern as compared to mid-late Holocene (5.1 kyrs BP) times in the study area (Gischler and Storz, 2009). This interpretation was largely corroborated by Wooller et al. (2009) who analyzed the floral pollen composition in pushcores collected in Turneffe Islands, which indicate drying from 4.1-2.9 kyrs BP. The data also fit in the idea of the existence of a Holocene climate optimum during the early Holocene as shown in adjacent (Haug et al. 2001) and global (Marcott et al. 2013) data sets.

Extension-rate and metal/calcium ratio timeseries from corals (Orbicella) from Turneffe Islands and the Belize Barrier Reef were used to identify the increasing influence of environmental and anthropogenic stressors such as high temperature events and run-off (Carilli et al. 2009a, b). Coral recovery after bleaching events was much slower in anthropogenically affected sites as compared to unaffected sites (Carilli et al. 2009c). Using the same samples, Kwiatkowski et al. (2013) investigated the relationship between coral extension-rate, sea surface temperature, and anthropogenic aerosols. Based on additional coral cores from Turneffe nd the barrier reef, Carilli et al. (2013) looked into the correlation of coral $\delta^{18} \mathrm{O}$ shifts and dinoflagellate symbionts and found some evidence that different zooxanthellate clades apparently leave different isotopic compositions in the coral skeletons.

Interestingly, no studies of changes on reefs and reef islands involved with cyclone landfalls in Belize have been conducted that are comparable to the ones of David Stoddart. Paleotempestology studies have been conducted though, using shallow cores from along the Belize coast (McCloskey and Keller; 2009; McCloskey and Liu, 2012; Adomat and Gischler, 2016) and the Belize atolls. In the Lighthouse Reef lagoon, the famous Blue Hole represents a $125 \mathrm{~m}$ deep inundated Pleistocene karst sinkhole (Cousteau and Diolé, 1973; Dill, 1977; Dill et al., 1998; Gischler et al., 2017). Due to the anoxic nature of the bottom water, bioturbation in the bottom sediments is absent. Gischler et al. $(2008,2013 \mathrm{a})$ and Denommee et al. (2014) have used coarse-grained (event) layers intercalated into the fine-grained, annually laminated sediments to develop highly resolved, late Holocene (1.5-0 kyrs BP) storm archives. Times of increased storm activity were identified during 1.3-0.9 and 0.8-0.5 kyrs BP. Gischler et al. (2008) additionally analyzed $\delta^{18} \mathrm{O}$ and $\delta^{13} \mathrm{C}$ in their cores and came up with a climate curve for the past ca. 1.5 kyr BP, which exhibits climate variability including the Medieval Warm Period, the Little Ice Age, and the industrial warming. The $\delta^{13} \mathrm{C}$-record is probably an expression of terrestrial runoff and the impact of the classic Maya civilization.

\section{Reef Ecology and Paleoecology}

One of the first marine ecological studies on the Belize atolls was the work by Wallace and Schafersman (1977) on benthic foraminifera and stony corals, based on two theses (Schafersman, 1972; Wallace, 1974). Miliolid foraminifera were identified to be most abundant on patch reefs. A patch reef assemblage and an adjacent lagoon floor assemblage were distinguished. Three stony coral assemblages (Orbicella, Acropora, Algae-Porites) showed a zonation away from major channels through the reef margin, and were interpreted as stages of recolonization following a disturbance event.

Gischler et al. (2003) systematically studied foraminifera in the three atolls. They identified some 150 species and delineated four assemblages characterizing the fore reef, the marginal reef, low-energy platform interior, and shallow patch reef and carbonate shoal environments. Depositional energy and water circulation appear to be significant factors of foraminifera distribution as highest biodiversity was found in Lighthouse Reef and lowest diversity in Turneffe Islands. The distribution of foraminifera through time was analyzed by Schultz et al. (2010) using vibracores from Belize atoll lagoons. By and large, diversity increases in the cores suggesting diversification during the Holocene. Seven assemblages may be distinguished, the distribution of which is controlled by changes in water circulation, habitat size, 
and habitat heterogeneity. Hauser et al. $(2007,2008)$ investigated distribution and taphonomy of bivalve mollusks in surface sediments of the three Belize atolls. It was possible to separate five mollusk-based depositional environments in Glovers Reef, three in Lighthouse Reef, and seven in Turneffe Islands, reflecting geomorphological and habitat diversity. Hauser et al. (2007) also collected highly resolved sea surface temperature and salinity data from all atoll lagoons over a two-year period. The distribution of cryptic fauna dwelling under and within coral rubble was analyzed in Glovers Reef and the barrier reef and also allowed to separate major reef environments (Gischler and Ginsburg, 1996).

Numerous studies have focused on the role of fleshy algae in Glovers Reef lagoonal patch reefs, and the environmental factors possibly responsible for the coral-to-algal phase shifts, which have been identified on many Caribbean reefs. McClanahan and Muthiga (1998) and McClanahan et al. (1999) compared recent hard coral distribution in the Glovers reef lagoon with those mapped by Wallace and Schafersman (1977) in the 1970s. They found a $75 \%$ loss in hard coral and a $99 \%$ loss in acroporid cover, whereas they observed a 315\% increase in brown algae. A later survey showed that there were no distinct areas of coral dominance anymore; only Orbicella-Agaricia occurrences were similar to the 1970s (McClanahan and Karnauskas 2011). In this context, McClanahan (1999) speculated about the role of the Caribbean-wide die-out of the grazer Diadema antillarum (Lessios et al., 1984), which has been recolonizing reefs slowly (Lessios, 2005). An analysis of the distribution of the grazer Echinometra viridis showed, however, that its abundance correlated positively with fleshy algal abundance. The study by Gischler (2010b) on fossil Diadema and Echinometra die-outs in cores from Belize atoll lagoons showed that at least three previous events had probably happened during 6.4-6.1 kyrs BP and around 4 kyrs BP and 1.3 kyrs BP. McClanahan et al. (2000, 2001) experimented with artificial algae reduction on patch reefs in Glovers Reef, which resulted in the increase of certain fish taxa due to increased accessibility, net production, and palatability of early succession turf algae. McClanahan et al. (2002, 2003 ) also showed with field experiments that a combination of a loss in grazing fish, nutrient input, and loss in hard coral cover contributed to algal cover and biomass in reefs. Elevated inorganic fertilizer and organic matter caused high algal biomass (McClanahan et al. 2005); nitrogen and phosphorous fertilizers caused turf algal cover to increase (McClanahan et al. 2007).

Biological studies on marine mammals and fish include the work of Dick and Hines (2011) and Edwards et al. (2014) who conducted censuses of marine mammals such as bottlenose dolphins and manatees in Turneffe Islands. A curious occurrence of a lone female bottlenose dolphin in the Lighthouse Reef lagoon was reported by Dudzinski et al. (1995). Fisheries studies were performed in both Glovers Reef and Turneffe Islands. Pikitch et al. (2005) monitored the spatial and temporal distribution of sharks and rays (elasmobranchs) in Glovers Reef. Starr et al. (2007) found that Nassau grouper abundance and numbers of spawning aggregations at the prominent spawning site at the northeastern margin of the platform has declined, like in many other Caribbean grouper spawning locations. Likewise, Babcock et al. (2013) showed that black grouper, Nassau grouper, mutton snapper, and schoolmaster snapper are overfished in Glovers Reef. Spiny lobster apparently occurs in all habitats in Glovers Reef, with the large adults most commonly dwelling in the deep fore reef (Acosta and Robertson (2003). Sclero-ecological studies of queen conch in the lagoon of Glovers Reef showed that maximum shell size is already reached after 2 years (Radermacher et al., 2009). Growth is apparently controlled by precipitation, run-off, and food supply and occurs during spring and winter and ceases in winter. Element concentrations in fish otoliths from the French grunt and the schoolmaster grouper were used to differentiate reef and mangrove habitats in Turneffe Islands (Chittaro et al., 2005, 2006). The settlement pattern of the slender filefish was monitored at Turneffe Islands (Ben-David and Kritzer, 2005).

\section{CONCLUDING REMARKS}

An enormous body of data has accumulated based on research on the Belize atolls since the late 1950s and early 1960s. This includes studies on reef geomorphology, reef sedimentology including diagenesis, late Quaternary reef development, paleoclimate including paleotempestology and sea level, as well as ecology and paleoecology. Most if not all of these topics have been touched by the early work of 
David Stoddart, which can be characterized as having both fundamental and seminal character. Still, and fortunately for research, many data gaps and open questions remain such as, e.g., detailed geomorphology of the fore reef areas, the origin of reef microbialite and carbonate mud, reef response to Holocene environmental and climate variability, marine cementation and microbialites, high-resolution climate archives such as coral skeletons or speleothems, or various ecological and paleoecological issues.

\section{PERSONAL NOTE}

My first encounter with the name of David Stoddart was during my Ph.D.-work in the late 1980s, in which I worked on Devonian atoll-like reefs in Germany. At one time I was especially interested in modern reef islands, their formation, and their orientation with regard to prevailing currents, as a model for the fossil record. I had detected a peculiar rubble facies in a Devonian atoll lagoon that showed clear diagenetic evidence of subaerial cementation, and I interpreted the lithology as a reef island facies. My supervisor Dieter Meischner recommended to look in the literature for the names Stoddart and Steers, so I ended up with their review paper on reef islands of 1977, which was extremely helpful. Sometime later, looking for positions after having finished my dissertation, I had visited Bob Ginsburg in Miami, and he recommended to me to start a project in Belize. One of the first titles on Belize reefs I found was Stoddart's 1962 dissertation on the atolls Glovers Reef, Lighthouse Reef, and Turneffe Islands, published in the Atoll Research Bulletin. After reading, it struck me that the three Belizean atolls, even though so close to one another in the same setting, had developed such different geomorphologies. In order to find out why they are so different, I developed a drilling proposal, which was fortunately granted. The first drilling in Belize was performed on Glovers Reef together with Harold Hudson from Miami in 1995. We stayed at the Glovers Reef Research Station on Middle Cay, which was not yet in operation at the time and which is now run by the Wildlife Conservation Society. A number of research projects in Belize followed in the next couple of years, and my habilitation-thesis (Gischler, 1999) focussed on late Quaternary reef development of the Belize atolls including the atoll Banco Chinchorro off the coast of the Yucatan Peninsula (Mexico). I had been sending reprints of my Belize papers to David Stoddard, and I found a postcard from 2002 and a letter from 2004 from him in my files commenting on them. Apparently, he was reading them with interest. When I first met David Stoddart at a European meeting of the International Society for Reef Studies in Cambridge in 2002, we talked a lot about the subsurface data from the Belize atolls, and it turned out that he must have read my papers quite carefully, because he knew virtually everything of what I had found out. I met him once more at the 11th International Coral Reef Symposium in Fort Lauderdale in 2008, and we talked about the Maldives, where I had started a project and where he had worked also in the 1960s. But we eventually came back to the Belize atolls where both his and my work on modern coral reefs had begun with doctoral and habilitation theses, respectively.

\section{ACKNOWLEDGMENTS}

I am grateful to Roger McLean (Canberra) and Tom Spencer (Cambridge) for inviting me to write this review during our conversation after the Stoddart-Session at the 13th International Coral Reef Symposium in Honolulu, Hawaii, in July 2016.

\section{REFERENCES}

Acosta, C. A., and D. N. Robertson. 2003. Comparative spatial ecology of fished spiny lobsters Palinurus argus and an unfished congener P.gattatus in an isolated marine reserve at Glover's Reef atoll, Belize. Coral Reefs, 22:1-9. 
Adomat, F., and E. Gischler. 2016. Assessing the suitability of Holocene environments along the central Belize coast, Central America, for the reconstruction of hurricane records. International Journal of Earth Sciences, 105: doi: 10.1007/s00531-016-1319-y.

Babcock, E. A., R. Coleman, M. Karnauskas, and J. Gibson. 2013. Length-based indicators of fishery and ecosystem status: Glover's Reef Marine Reserve, Belize. Fisheries Research, 147: 434-445.

Ben-David, J., and J. P. Kritzer. 2005. Early life history and settlement of the slender filefish, Monocanthus tuckeri (Monocanthidae), at Calabash Caye, Turneffe Atoll, Belize. Environmental Biology of Fishes, 73: 275-282.

Carilli, J. E., C.D. Charles, M. Garren, M. McField, and R. D. Norris. 2013. Baseline shifts in coral skeletal oxygen isotopic composition: a signature of symbiont shuffling? Coral Reefs, 32: 559571.

Carilli, J. E., R. D. Norris, B. Black, and S. M. Walsh. 2009a. Century-scale records of coral growth rates indicate that local stressors reduce coral thermal tolerance threshold. Global Change Biology, 16: $1247-1257$.

Carilli, J. E., R. D. Norris, B. A. Black, S. M. Walsh, and M. McField. 2009b. Local stressors reduce coral resilience to bleaching. PLoS ONE, 4: e6324.

Carilli, J. E., N. G. Prouty, K. A. Jughen, and R. D. Norris. 2009c. Century-scale records of land-based activities recorded in Mesoamerican coral cores. Marine Pollution Bulletin, 58: 1835-1842.

Carr, D., and J. Thorpe. 1961. From the Cam to the Cays. The story of the Cambridge Expedition to British Honduras 1959-60. 190 pp., Putnam, London.

Chittaro, P. M., P. Usseglio, B. J. Fryer, and P. F. Sale. 2005. Using otolith microchemistry of Haemulon flaviolineatum (French grunt) to characterize mangroves and coral reefs throughout Turneffe Atoll, Belize: difficulties at small spatial scales. Estuaries, 28: 373-381.

Chittaro, P. M., P. Usseglio, B. J. Fryer, and P. F. Sale. 2006. Spatial variation in otolith chemistry of Lutjanus apodus at Turneffe Atoll, Belize. Estuarine Coastal and Shelf Science, 67: 673-680.

Choi, D. R., and R. N. Ginsburg. 1982. Siliciclastic foundations of Quaternary reefs in the southernmost Belize lagoon, British Honduras. Geological Society of America Bulletin, 93: 116-126.

Choi, D. R., and C. W. Holmes. 1982. Foundations of Quaternary reefs in south-central Belize lagoon, British Honduras. American Association of Petroleum Geologists Bulletin, 66: 2663-2671.

Cousteau, J. -Y., and P. Diolé. 1973. Three adventures. Galápagos, Titicaca, the Blue Holes, Doubleday, Garden City, New York, 304 pp.

Darwin, C. R. 1842. Structure and distribution of coral reefs. Smith Elder, London, 214 pp.

Denommee, K. C., S. J. Bentley, and A. W. Droxler. 2014. Climatic controls on hurricane patterns: a 1200-y near-annual record from Lighthouse Reef, Belize. Scientific Reports, 4: 3876, doi: $10.1038 /$ sre03876.

Dick, D. M., and E. M. Hines. 2011. Using distance sampling techniques to estimate bottlenose dolphin (Tursiops truncatus) abundance at Turneffe Atoll, Belize. Marine Mammal Science, 27: 606-621.

Dill, R. F. 1977. The blue holes: geologically significant submerged sinkholes and caves off British Honduras and Andros, Bahama Islands. Proceedings 2nd International Coral Reef Symposium, 2: 237-242.

Dill, R. F., L. S. Land, L. E. Mack, and H. P. Schwarcz. 1998. A submerged stalactite from Belize: petrography, geochemistry, and geochronology of massive marine cementation. Carbonates and Evaporites, 13: 189-197.

Druffel, E. M. 1980. Radiocarbon in annual coral rings of Belize and Florida. Radiocarbon, 22: 363-371.

Dudzinski, K. M., T. G. Frohoff, and N. L. Crane. 1995. Behavior of a lone female bottlenose dolphin (Tursiops truncatus) with humans off the coast of Belize. Aquatic Mammals, 21: 149-153.

Edwards, H. H., S. B. P. Stone, E. M. Hines, N. A. Gomez, and B. E. Winning. 2014. Documenting manatee (Trichechus manatus manatus) presence at Turneffe Atoll, Belize, Central America and its conservation significance. Caribbean Journal of Science, 48: 71-75.

van Ee, N. J. 2013. Quaternary growth history of Glover's Reef, Belize: insights into reef distribution, ecological change, and late Pleistocene sea level. Unpublished Ph.D. thesis, University of Miami, Miami, Florida, 175 pp. 
van Ee, N. J., K. E. Cooper, D. S. Kaufman, and G. P. Eberli. 2012. Evaluation of amino acid racemization variability in Quaternary corals. Proceedings 12th International Coral Reef Symposium, 8E Growth records in coral cores, $5 \mathrm{p}$.

Esker, D., G. P. Eberli, and D. F. McNeill. 1998. The structural and sedimentological controls on the reoccupation of Quaternary incised valleys, Belize southern lagoon. AAPG Bull., 82, 2075-2109.

Fairbridge, R. W. 1950. Landslide patterns on oceanic volcanoes and atolls. Journal of Geography, 115: $82-88$.

Ferro, C. E., A. W. Droxler, J. B. Anderson, and D. Mucciarone. 1999. Late Quaternary shift of mixed siliciclastic-carbonate environments induced by glacial eustatic sea-level fluctuations in Belize. In Advances in Carbonate Sequence Stratigraphy: Applications to Reservoirs, Outcrops, and Models, eds. P. M. Harris, A. H. Saller, and J. A. Simo, Society of Economic Paleontologists and Mineralogists Special Publication, 63: 385-411.

Folk, R. L, and R. Robles. 1964. Carbonate sands of Isla Perez, Alacran Reef, Yucatan. Journal of Geology, 72: 255-292.

Ginsburg, R. N. 1953. Beachrock in south Florida. Journal of Sedimentary Petrology, 23: 85-92.

Ginsburg, R. N., and N. P. James. 1976. Submarine botryoidal aragonite in Holocene reef limestones, Belize. Geology, 4: 431-436.

Gischler, E. 1994. Sedimentation on three Caribbean atolls: Glovers Reef, Lighthouse Reef and Turneffe Islands, Belize. Facies, 31: 243-254.

Gischler, E. 1999. Reef development in the late Quaternary: carbonate platforms in Belize and SE Mexico (Central America). Habilitation-thesis, Goethe University, 168 p., Frankfurt, Germany.

Gischler, E. 2003. Holocene lagoonal development in isolated carbonate platforms of Belize. In Impact of sea level and climate on Quaternary reef development, eds. Blanchon, P., and L. Montaggioni. Sedimentary Geology, 159: 113-132.

Gischler. E. 2007a. Pleistocene facies of Belize barrier and atoll reefs. Facies, 53: 27-41.

Gischler, E. 2007b. Beachrock and intertidal precipitates. In Chemical Sediments and Landscapes, eds. Rigby, D., and S. MacLaren, pp. 365-390, Blackwell, Oxford.

Gischler, E. 2008. Accretion patterns in Holocene tropical coral reefs: do massive coral reefs with slowly growing corals accrete faster than branched coral (acroporid) reefs with rapidly growing corals? International Journal of Earth Sciences, 97: 851-859.

Gischler, E. 2010a. Edward George Purdy 1931-2009. Memorial. AAPG Bulletin, 94: 258-259.

Gischler, E. 2010b. Possible fossil echinoid mass mortality detected in Holocene lagoons, Belize. Palaios, 25: 260-268.

Gischler, E., F.S. Anselmetti, and E.A. Shinn. 2013a. Seismic stratigraphy of the Blue Hole sediments (Lighthouse Reef, Belize), a late Holocene climate and storm archive. Marine Geology, 344: 155162.

Gischler, E., D. Birgel, B. Brunner, A. Eisenhauer, G. Meyer, S. Buhre, and J. Peckmann. 2017. A giant underwater stalactite from the Blue Hole, Belize, revisited: a complex history of massive carbonate accretion under changing meteoric and marine conditions. Journal of Sedimentary Research, 87: 1260-1284.

Gischler, E., S. Dietrich, D. Harris, J. Webster, and R. N. Ginsburg. 2013b. A comparative study of carbonate mud in reefs and carbonate platforms: mostly biogenic, some precipitated. Sedimentary Geology, 292: 36-55.

Gischler, E., and R. N. Ginsburg. 1996. Cavity dwellers (coelobites) under rubble in southern Belize barrier and atoll reefs. Bulletin of Marine Science, 58: 570-589.

Gischler, E., R. N. Ginsburg, J. O. Herrle and S. Prasad. 2010. Mixed carbonates and siliciclastics in the Quaternary of southern Belize: Pleistocene turning points in reef development controlled by sealevel change. Sedimentology, 57: 1049-1068.

Gischler, E., I. Hauser, K. Heinrich, and U. Scheitel. 2003. Characterization of depositional environments in carbonate platforms based on benthic foraminifera, Belize, Central America. Palaios, 18: 236255. 
Gischler, E., and J. H. Hudson. 1998. Holocene development of three isolated carbonate platforms, Belize, Central America. Marine Geology, 144: 333-347.

Gischler, E., and J. H. Hudson. 2004. Holocene development of the Belize Barrier Reef. Sedimentary Geology, 164: 223-236.

Gischler, E., and A. J. Lomando. 1997. Holocene cemented beach deposits in Belize. Sedimentary Geology, 111: 277-297.

Gischler, E., and A. J. Lomando. 1999. Recent sedimentary facies of isolated carbonate platforms, BelizeYucatan system, Central America. Journal of Sedimentary Research, 69: 747-763.

Gischler, E., and A. J. Lomando. 2000. Isolated carbonate platforms of Belize, Central America: sedimentary facies, late Quaternary history and controlling factors. In Carbonate platform systems: components and interactions, eds. Insalaco, E., P.W. Skelton, and T. J. Palmer. Geological Society of London, Special Publication, 178: 135-146.

Gischler, E., A. J. Lomando, J. H. Hudson, and C. W. Holmes. 2000. Last interglacial reef growth beneath Belize barrier and isolated platform reefs. Geology, 28: 387-390.

Gischler, E., and W. Oschmann. 2005. Historical climate variation in Belize (Central America) as recorded in Scleractinian coral skeletons. Palaios, 20: 159-174.

Gischler, E., and A. Pisera. 1999. Shallow water rhodoliths from Belize reefs. Neues Jahrbuch für Geologie und Paläontologie Abhandlungen, 214: 71-93.

Gischler, E., E. A. Shinn, W. Oschmann, J. Fiebig, and N. A. Buster. 2008. A 1,500 year Holocene Caribbean climate archive from the Blue Hole, Lighthouse Reef, Belize. Journal of Coastal Research, 24: 1495-1505.

Gischler, E., and D. Storz. 2009. High-resolution windows into Holocene climate using proxy data from Belize corals (Central America). Palaeobiodiversity Palaeoenvironments, 89: 211-221.

Gischler, E., P. K. Swart, and A. J. Lomando. 2009. Stable isotopes of carbon and oxygen in modern sediments of carbonate platforms, barrier reefs, atolls, and ramps: patterns and implications. In Perspectives in Sedimentary Geology: A Tribute to the Career of Robert Ginsburg, eds. Swart, P. K., G. P. Eberli, and J. A. McKenzie. International Association of Sedimentologists Special Publication, 41: 61-74.

Grammer, G. M., R. N. Ginsburg, P. K. Swart, D. F. McNeill, A. J. Jull, and D. R. Prezbindowski. 1993. Rapid growth rates of syndepositional marine aragonite cements in steep marginal slope deposits, Bahamas and Belize. Journal of Sedimentary Petrology, 63: 983-989.

Halley, R. B., E. A. Shinn, J. H. Hudson, and B. Lidz. 1977. Recent and relict topography of Boo Bee patch reef, Belize. Proceedings 3rd International Coral Reef Symposium, 2: 29-35.

Haug, G. H., K. A. Hughen, D. M. Sigman, L. C. Peterson, and U. Röhl. 2001. Southward migration of the intertropical convergence zone through the Holocene. Science, 293: 1304-1308.

Hauser, I., W. Oschmann, and E. Gischler. 2007. Modern bivalve shell assemblages on three atolls offshore Belize (Central America, Caribbean Sea). Facies, 53: 451-478.

Hauser, I., W. Oschmann, and E. Gischler. 2008. Taphonomic signatures on modern Caribbean bivalve shells offshore Belize as indicators of environmental conditions. Palaios, 23: 586-600.

Heindel, K., D. Birgel, B. Brunner, V. Thiel, H. Westphal, S.B. Ziegenbalg, E. Gischler, G. Cabioch, and J. Peckmann, J. 2012. Post-glacial microbialite formation in coral reefs in the Pacific Ocean, Caribbean, and Indian Ocean. Chemical Geology, 304-305: 117-130.

James, N. P., and R. N. Ginsburg. (eds.) 1979. The Seaward Margin of Belize Barrier and Atoll Reefs. International Association of Sedimentologists Special Publication, 3: 1-191, Blackwell, Oxford.

James, N. P., R. N. Ginsburg, D. S. Marszalek, and P. W. Choquette. 1976. Facies and fabric specificity of early subsea cements in shallow Belize (British Honduras) reefs. Journal of Sedimentary Petrology, 46: 523-544.

Kwiatkowski, L., P. M. Cox, T. Economou, P. R. Halloran, P. J. Mumby, B. B. B. Booth, J. Carilli, and H. M. Guzmann. 2013. Caribbean coral growth influence by anthropogenic aerosol emissions. Nature Geoscience, 6: 362-366.

Lara, M. E. 1993. Divergent wrench faulting in the Belize southern lagoon: implications for Tertiary Caribbean plate movements and Quaternary reef distribution. American Association of Petroleum 
Geologists Bulletin, 77: 1041-1063.

Lessios, H. A. 2005. Diadema antillarum populations in Panama twenty years following mass mortality. Coral Reefs, 24: 125-127.

Lessios, H. A., D. R. Robertson, and J. D. Cubit. 1984. Spread of Diadema mass mortality through the Caribbean. Science, 226: 335-337.

Macintyre, L G., R. B. Burke, and R. Stuckenrath. 1981. Core holes in the outer fore reef of Carrie Bow Cay. Belize: a key to the Holocene history of the Belize barrier reef complex. Proceedings 4th International Coral Reef Symposium, 1: 567-574.

Macintyre, I. G., M. M. Littler, and D. S. Littler. 1995. Holocene history of Tobacco Range, Belize, Central America. Atoll Research Bulletin, 430: 1-18.

Macintyre, I. G., W. F. Precht, and R.B. Aronson. 2000. Origin of the Pelican Cays ponds, Belize. Atoll Research Bulletin, 466: 1-11.

Macintyre, I. G., M. A. Toscano, R. G. Lightly, and G. R. Bond. 2004. Holocene history of the mangrove islands of Twin Cays, Belize, Central America. Atoll Research Bulletin, 510: 1-16.

Marcott, S. A., J. D. Shakun, P. U. Clark, and A. C. Mix. 2013. A reconstruction of regional and global temperature for the past 11,300 years. Science, 339: 1198-1201.

Mazzullo, S. J. 2006. Late Pliocene to Holocene platform evolution in northern Belize, and comparison with coeval deposits in southern Belize and the Bahamas. Sedimentology, 53: 1015-1047.

McClanahan, T. R. 1999. Predation and the control of the sea urchin Echinometra viridis and fleshy algae in the patch reefs of Glovers Reef, Belize. Ecosystems, 2: 511-523.

McClanahan, T. R., R. B. Aronson, W. F. Precht, and N. A. Muthiga. 1999. Fleshy algae dominate remote coral reefs of Belize. Coral Reefs, 18: 61-62.

McClanahan, T. R., K. Bergman, M. Huitric, M. McField, T. Elfwing, M. Nystrom, and I. Nordema. 2000. Response of fishes to algae reduction on Glovers Reef, Belize. Marine Ecology Progress Series, 206: 273-282.

McClanahan, T. R., M. Carreiro-Silva, and M. DiLorenzo. 2007. Effect of nitrogen, phosphorous, and their interaction on coral reef algal succession in Glover's Reef, Belize. Marine Pollution Bulletin, 54: 1947-1957.

McClanahan, T. R., B. A. Cokos, and E. Sala. 2002. Algal growth and species composition under experimental control of herbivory, phosphoris and coral abundance in Glovers Reef, Belize. Marine Pollution Bulletin, 44: 441-451.

McClanahan, T. R., and M. Karnauskas. 2011. Relationship between benthic cover, current strength, herbivory, and a fisheries closure in Glovers Reef Atoll, Belize. Coral Reefs, 30: 9-19.

McClanahan, T. R., M. McField, M. Huitric, K. Bergmann, E. Sala, M. Nystrom, I. Nordemar, T. Elfwing, and N. A. Muthiga. 2001. Responses of algae, corals and fish to the reduction of macroalgae in fished and unfished patch reefs of Glovers Reef Atoll, Belize. Coral Reefs, 19: 367-379.

McClanahan, T. R., and N. A. Muthiga. 1998. An ecological shift in a remote coral atoll of Belize over 25 years. Environmental Conservation, 25: 122-130.

McClanahan, T. R., E. Sala, P. A. Stickels, B. A. Cokos, A. C. Baker, C. J. Starger, S. H. Jones. 2003. Interaction between nutrients and herbivory in controlling algal communities and coral condition on Glover's Reef, Belize. Marine Ecology Progress Series, 261: 135-147.

McClanahan, T. R., R. S. Steneck, D. Pietri, B. Cokos, and S. Jones. 2005. Interaction between inorganic nutrients and organic matter in controlling coral reef communities in Glovers Reef, Belize. Marine Pollution Bulletin, 50: 566-575.

McCloskey, T. A., and G. Keller. 2009. 5000 year sedimentary record of hurricane strikes on the central coast of Belize. Quaternary International, 195: 53-68.

McCloskey, T. A., and K .-B. Liu. 2012. A 7000 year record of paleohurricane activity from a coastal wetland in Belize. The Holocene, 23: 278-291.

McCloskey, T. A., and K. -B. Liu. 2013. Sedimentary history of mangrove cays in Turneffe Islands, Belize: evidence for sudden environmental reversal. Journal of Coastal Research, 29: 971-983. 
Mullins, H. T., and A. C. Hine. 1989. Scalloped bank margins: beginning of the end for carbonate platforms? Geology, 17: 30-33.

Pikitch, E. K., D. D. Chapman, E. A. Babcock, and M. S. Shivji. 2005. Habitat use and demographic population structure of elasmobranchs at a Caribbean atoll (Glover's Reef, Belize). Marine Ecology Progress Series, 302: 187-197.

Purdy, E. G. 1974a. Karst determined facies patterns in British Honduras: Holocene carbonate sedimentation model. American Association of Petroleum Geologists, Bulletin, 58: 825-855.

Purdy, E. G. 1974b. Reef configurations: cause and effect. In Reefs in Time and Space ed. Laporte, L.F. Society of Economic Paleontologists and Mineralogists, Special Publication, 18: 9-76.

Purdy, E. G., and E. Gischler. 2003. The Belize margin revisited: 1. Holocene marine facies. In New perspectives in carbonate sedimentology, eds. Reijmer, J. J.G., C. Betzler, and M. Mutti. International Journal of Earth Sciences, 92: 532-551.

Purdy, E. G., and E. Gischler. 2005. The transient nature of the empty bucket model of reef sedimentation. In Sedimentology in the 21st century - a tribute to Wolfgang Schlager, eds. Reijmer, J.J.G., and A. Immenhauser. Sedimentary Geology, 175: 35-47.

Purdy, E. G., E. Gischler, and A. J. Lomando. 2003. The Belize margin revisited: 2. Origin of Holocene antecedent topography. In New perspectives in carbonate sedimentology, eds. Reijmer, J. J. G., C. Betzler, and M. Mutti. International Journal of Earth Sciences, 92: 552-572.

Purkis, S. J., G. R. Rowlands, and J. M. Kerr. 2015. Unravelling the influence of water depth and wave energy on the facies diversity of shelf carbonates. Sedimentology, 62, 541-565.

Radermacher, P., B. R. Schöne, W. Oschmann, E. Gischler, J. Thebauldt, and J. Fiebig. 2009. Sclerochronology - a highly versatile tool for mariculture and reconstruction of life history traits of the queen conch, Strombus gigas (Gastropoda). Aquatic Living Resources, 22: 307-318.

Schafersman, S. D. 1972. Carbonate sediments and foraminifera of patch reefs, Glovers Reef, British Honduras. M.Sc.thesis Northern Illinois University, 99 p., Dekalb, Illinois.

Schultz, S., E. Gischler, and W. Oschmann. 2010. Diversity, distribution, and assemblages of benthic foraminifera in atoll lagoons during the Holocene, Belize, Central America. Facies, 56: 323-336.

Shcherbina, A. Y., G. G. Gawarkiewicz, C. A. Linder and S. R. Thorrold. 2008. Mapping bathymetric and hydrographic features of Glover's Reef, Belize, with a REMUS autonomous underwater vehicle. Limnology Oceanography, 53: 2264-2272.

Shinn, E. A., J. H. Hudson, R. B. Halley, B. Lidz, L .G. Robbin, and I. G. Macintyre. 1982. Geology and sediment accumulation rates at Carrie Bow Cay, Belize. In The Atlantic barrier reef ecosystem at Carrie Bow Cay, Belize, I. Structure and communities, eds. Rützler, K., and I. G. Macintyre. Smithsonian Contributions Marine Science, 12: 63-75.

Smith, F. G. W. 1939. Sponge mortality at British Honduras. Nature, 144: 785.

Smith, F. G. W. 1941. Sponge disease in British Honduras, and its transmission by water currents. Ecology, 22: 415-421.

Starr, R. M., E. Sala, E. Ballesteros, and M. Zabala. 2007. Spatial dynamics of the Nassau grouper (Epinephelus striatus) in a Caribbean atoll. Marine Ecology Progress Series, 343: 239-249.

Stoddart, D. R. 1962a. Three Caribbean atolls: Turneffe Islands, Lighthouse Reef, and Glover's Reef, British Honduras. Atoll Research Bulletin, 87: 1-151.

Stoddart, D. R. 1962b. Catastrophic storm effects on the British Honduras reefs and cays. Nature, 196: $512-515$.

Stoddart, D. R. 1963. Effects of Hurricane Hattie on the British Honduras reefs and cays, October 30-31, 1961. Atoll Research Bulletin, 95: 1-29.

Stoddart, D. R. 1964. Carbonate sediments of Half Moon Cay, British Honduras. Atoll Research Bulletin, 104: $1-16$.

Stoddart, D. R. 1965a. The shape of atolls. Marine Geology, 3: 369-383.

Stoddart, D. R. 1965b. British Honduras cays and the low wooded island problem. The Institute of British Geographers Transactions and Papers, 36: 131-147.

Stoddart, D. R. 1965c. Re-survey of hurricane effects on the British Honduras reefs and cays. Nature, 207: 589-592. 
Stoddart, D. R. 1969. Post-hurricane changes on the British Honduras reefs and cays: re-survey of 1965. Atoll Research Bulletin, 131: 1-25.

Stoddart, D. R. 1973. Coral reefs: the last two million years. Geography, 58: 313-323.

Stoddart, D. R. 1974. Post-hurricane changes on the British Honduras reefs: re-survey of 1972. Proceedings 2nd International Coral Reef Symposium 2: 473-483.

Stoddart, D. R., and J. R. Cann. 1965. Nature and origin of beachrock. Journal of Sedimentary Petrology, 35: 243-273.

Stoddart, D. R., and F. R. Fosberg. 1982. Species-area relationships on small islands: floristic data from Belizean sand cays. In The Atlantic barrier reef ecosystem at Carrie Bow Cay, Belize, I. Structure and communities, eds. Rützler, K., and I. G. Macintyre. Smithsonian Contributions Marine Science, 12: 527-539.

Stoddart, D. R., and J. A. Steers. 1977. The nature and origin of coral reef islands. In Biology and Geology of Coral Reefs Geology 2, eds. Jones, O. A. and R. Endean, pp. 59-105, Academic Press, New York.

Terry, J. P., and J. Goff. 2012. One hundred and thirty years since Darwin: 'reshaping' the theory of atoll formation. The Holocene, 23: 615-619.

Wallace, R. J. 1974. A reconnaissance of the sedimentology and ecology of Glovers Reef Atoll, Belize (British Honduras). Ph.D. thesis, Princeton University, Princeton, New Jersey, 143 pp.

Wallace, R .J., and S. D. Schafersman. 1977. Patch reef ecology and sedimentology of Glovers Reef Atoll, Belize, In Reefs and Related Carbonates, eds. Frost, S. F., M. P. Weiss, and J. B. Saunders. American Association of Petroleum Geologists, Studies in Geology, 4: 37-53.

Wooller, M. J., H. Behling, J. L. Guerrero, N. Jantz, and M. E. Zweigert. 2009. Late Holocene hydrologic and vegetation changes at Turneffe atoll, Belize, compared with records from mainland central America and Mexico. Palaios, 24: 650-656. 


\title{
MAPPING THE LAGOON AT ALDABRA ATOLL, WESTERN INDIAN OCEAN
}

\author{
SARAH HAMYLTON ${ }^{1,2}$, ANNELISE HAGAN ${ }^{1}$, NANCY BUNBURY ${ }^{3}$, \\ FRAUKE FLEISCHER-DOGLEY ${ }^{3}$, and TOM SPENCER ${ }^{1}$
}

\begin{abstract}
Aldabra Atoll occupies a unique place among the world's atolls due to the wealth of biodiversity it supports, its relatively undisturbed status and its designation as a World Heritage Site. This landmark conservation designation was due largely to the scientific advocacy and campaigning work of David Stoddart, with its strong focus on creating detailed and accurate inventories of the biological and physical attributes of this remote atoll. The lagoon mapping campaign described in the present study continues this tradition, making use of recent developments in geospatial technology to provide a detailed snapshot of the large and shallow lagoon that has hitherto been unavailable to physical and ecological science. Here we provide the first detailed maps of benthic community character and bathymetry in the Aldabra lagoon, the output of two related mapping exercises undertaken in February 2009 as part of a collaborative project between Cambridge Coastal Research Unit and the Seychelles Islands Foundation. The lagoon environment of Aldabra Atoll was mapped using satellite remote sensing techniques in conjunction with detailed in situ ground-referencing conducted over a 3.5 week period with the aim of creating large-scale, high resolution habitat and bathymetry maps. A series of closed loop levelling surveys were undertaken to establish the relative positioning of a network of five benchmarks around the Research Station, providing a common vertical datum against which the bathymetric map could be referenced. Eight habitat groupings were identified in the lagoon, with the two dominant classes mapped being "sparse macroalgae and seagrass assemblage on sand" and "dense macroalgal mat on sand", which covered $35 \%$ and $33 \%$ of the lagoon area respectively. Variations in lagoon floor elevation range from -0.2 to $-30 \mathrm{~m}$. Much of the lagoon is a flat, shallow $(<3 \mathrm{~m})$ platform and the deepest areas are associated with the channels, particularly Grande Passe in the northwest. These maps represent a detailed record of the contemporary lagoon character against which future change of the lagoon environment can be monitored.
\end{abstract}

\section{INTRODUCTION}

Broadly, an atoll is defined as a circular or irregularly shaped, isolated oceanic reefs at or near sea level that enclose a lagoon usually tens of meters deep. The shallow and emergent margin of atolls contains islands and reefs around the outer rim, which typically comprise a smaller area than the lagoon (Goldberg, 2016). The UNESCO World Heritage site of Aldabra Atoll, Seychelles, western Indian Ocean, is well known as one of the most remarkable and least disturbed oceanic atolls on Earth. With only a small research station on Picard Island, human influence at Aldabra is extremely low and the atoll is a refuge for many endangered and endemic species. Amongst these are the Aldabra giant tortoise of which there are around 100,000; one of the largest congregations of nesting green turtles in the Indian Ocean; the world's second largest breeding population of greater and lesser frigate birds; and the last flightless bird species in the Indian Ocean, the white-throated rail (Stoddart and Ferrari, 1983). From the late 1960s, when the Royal Society of London established a research station on the atoll, to the early 1980s, a vigorous international research effort, amounting to over 50 years of person-effort (Stoddart, 1979), was applied to understanding many elements of this complex ecosystem (including terrestrial vegetation community mapping, geological mapping and tortoise population dynamics); that work has been

${ }^{1}$ Cambridge Coastal Research Unit, Department of Geography, University of Cambridge, UK

2 School of Earth and Environmental Sciences, University of Wollongong, Australia

3 Seychelles Islands Foundation, La Ciotat building, Mont Fleuri, Victoria, PO Box 853, Seychelles 
subsequently taken forward by the officers and research associates of the Seychelles Island Foundation (SIF). However, the physical and ecological characteristics of the atoll's lagoon are still, beyond its immediate rocky (Taylor, 1978) and mangrove-fringed (Macnae, 1971) margins, largely unknown. This is perhaps not surprising; it is a highly challenging environment in which to work, due to its great size and large flood and ebb tide fluxes (the atoll experiences a meso-tidal regime and nearly three quarters of the lagoon drains at low tide). These fluxes are associated with high tidal velocities that restrict small boat access and usage and the deployment of fixed instrumentation. Given the rapidly changing water levels that result from the semi-diurnal tidal fluctuations, the likelihood of seasonally variable water surface slopes across the lagoon and the lack of accurate positional information, conventional line or echosounding surveys related to a water surface datum are not possible. Rather, these difficulties mean that habitat mapping through remote sensing is the only way in which to map this environment within a relatively short time-frame.

In February 2009, a team from Cambridge Coastal Research Unit, ably supported by local SIF personnel, embarked on a 3.5 week expedition to map the lagoon environment of Aldabra Atoll, using satellite remote sensing techniques in conjunction with detailed in situ ground-referencing with the aim of creating a large-scale high resolution habitat map. Two related mapping exercises were undertaken, which focused on the benthic community character and the bathymetry of the lagoon (Hamylton et al., 2012a). Both hard copy and digital forms of this map have helped to fill knowledge gaps of western Indian Ocean marine biodiversity, for example, in modelling habitat suitability for dugong (Dugong dugon; Hamylton et al., 2012b) and have been incorporated into site management plans. These outputs represent a first baseline record of lagoon condition against which future change of the lagoon environment can be monitored.

\section{Location and Environment}

Located $420 \mathrm{~km}$ northwest of Madagascar and $620 \mathrm{~m}$ east of mainland Africa, Aldabra Atoll $\left(9^{\circ} 24^{\prime} \mathrm{S}, 46^{\circ} 22^{\prime} \mathrm{E}\right.$ ) is one of the largest atolls in the world, with a total area of $365 \mathrm{~km}^{2}$ (Andréfouët et al., 2009). The lagoon, at $203 \mathrm{~km}^{2}$, accounts for over half of the total area and is encircled by a series of narrow islands averaging $2 \mathrm{~km}$ in width (Figure 1). The four main islands of Grand Terre, Malabar, Picard and Polymnie are composed of 125, 000 year old limestone in the form of two platforms at $+4 \mathrm{~m}$ and +8 $\mathrm{m}$ above present mean sea level (Stoddart, 1984). The islands are separated by a number of deep (10-30 $\mathrm{m}$ depth) narrow channels that connect the lagoon to the surrounding ocean.

Initial measurements of tidal dynamics at Aldabra were made by HMS Owen, in a side channel to Grande Passe (Main Channel; Figure 1), between 14 January - 12 February 1962 and then by HMS Vidal over a 4 day period in 1967 ( 4 - 8 September). These records were, however, very short, and severely compromised by being within the tidal passes. The early benchmark paper on tidal dynamics at Aldabra is that by Farrow and Brander (1971). They variously occupied a number of stations within the lagoon and at the entrance to the passes, with detailed (but daylight) studies at Passe Houareau (East Channel) and Passe Gionnet (Figure 1); their prime station was in the West Channels, at Passe du Bois, and related to the Vidal benchmark on the islet at that site. Farrow and Brander (1971) had no long-term tidal records available and used published predictions for Kilindini/Dar es Salaam, over $600 \mathrm{~km}$ to the west of the atoll, to establish tidal curves for any station in the lagoon from the predicted Kilindini tidal curves. Subsequently, David Pugh undertook a year (1975-1976) of water level recording and analysis from a tide gauge positioned off the reef edge mid-way between the Research Station and Old Settlement on Picard (for bathymetry see Drew, 1977). This revealed that the compression of the rising and falling tide through a small number of channels into and out of the lagoon substantially modifies the semi-diurnal rhythm of the open ocean (a high tide every 12 hours), resulting in a reduced tidal range inside the lagoon. Thus, for example, whilst the tidal range at mean spring tides outside the atoll is $2.74 \mathrm{~m}$, at Passe Houareau (500 $\mathrm{m}$ into the lagoon from the channel mouth) the spring tidal range is only $1.2 \mathrm{~m}$ (Pugh and Rayner, 1981; Pugh, 1979). At the far eastern end of the atoll, at Bras Takamaka, high water is delayed by 4.5 hours at greatest spring tides; at neaps the whole region is dry at high water. Similar patterns characterise the southern margin of the lagoon, with a lag time of $3.5 \mathrm{hr}$ at Dune Jean-Louis. At low 


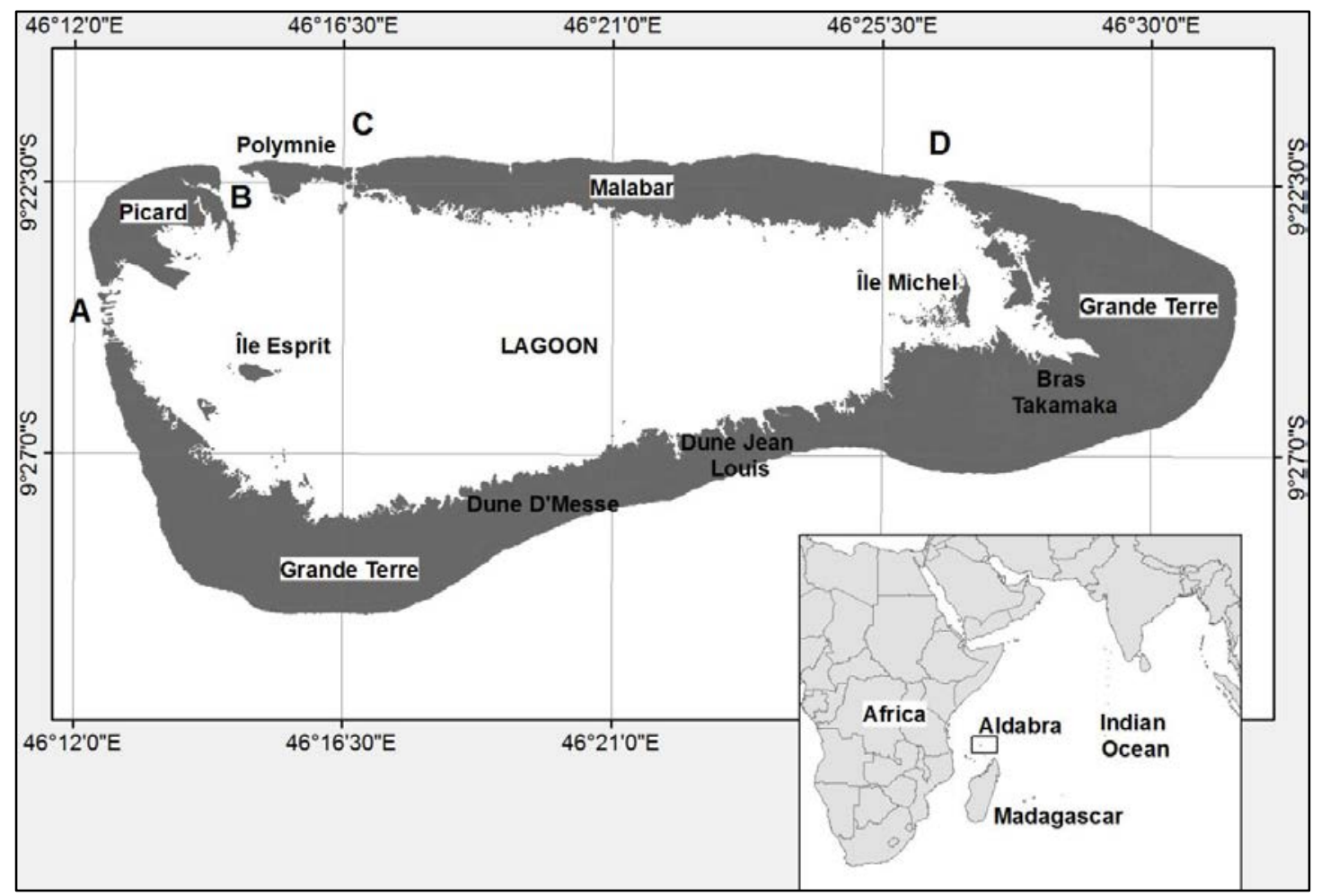

Figure 1. Location of Aldabra Atoll and map of Aldabra showing the four main islands of Grand Terre, Malabar, Picard and Polymnie. Channels connecting the lagoon to the open ocean are A) West Channels (including Passe du Bois); B) Grand Passe; C) Passe Gionnet; and D) Passe Houareau.

spring tides a substantial area of lagoon floor is also exposed at Dune d'Messe. The only places where there is reliable water at lowest springs are around the limestone islets within Passe Gionnet and along the westernmost and easternmost sectors of Malabar (Middle) Island. Little is known about lagoon tidal curves although they are thought to be asymmetrical, with ebb drainage for $9.5-10 \mathrm{hrs}$ of the $12.5 \mathrm{hr}$ tidal cycle. Towards spring tide, more water enters Passe Houareau than can drain away before the next tide. Water level gradually builds up until at high spring tides approximately $0.3 \mathrm{~m}$ water depth covers the lagoon platform. Extreme low water coincides with neap tides. Tidal currents are extreme: $1.5 \mathrm{~m} \mathrm{~s}^{-1}$ at Passe du Bois (one of the Western channels), probably reaching $3 \mathrm{~m} \mathrm{~s}^{-1}$ at Passe Houareau and over $3 \mathrm{~m} \mathrm{~s}$ ${ }^{1}$ at Passe Gionnet, peaking at $3.7 \mathrm{~m} \mathrm{~s}^{-1}$ (Farrow and Brander, 1971).

\section{METHODS}

\section{Mapping the Benthic Community Character of Aldabra Lagoon}

\section{Ground Referencing from Boat-based and in-situ SCUBA Surveys}

Records of the lagoon surface character were collected at 486 locations throughout the largely shallow and sheltered lagoon from a small boat (see Figure 2). Estimates of the areal coverage of different benthic classes were generated from a snapshot (typically 30 seconds) of oblique underwater video footage, covering an area of $10 \mathrm{~m}$. This was captured by a Seaviewer drop camera mounted on $50 \mathrm{~m}$ length of submarine cable. Within the lagoon, the depths of video referencing locations ranged from $1 \mathrm{~m}$ to approximately $20 \mathrm{~m}$. The tethered underwater video camera was lowered to drift approximately $10 \mathrm{~cm}$ above the lagoon floor. The geographical position of each footage sample was recorded by a differential GPS on the boat (positional accuracy $\pm 0.2 \mathrm{~m}$ ). Video camera surveys allowed efficient ground referencing over an extensive area of the lagoon during the 3.5 week fieldwork period. 


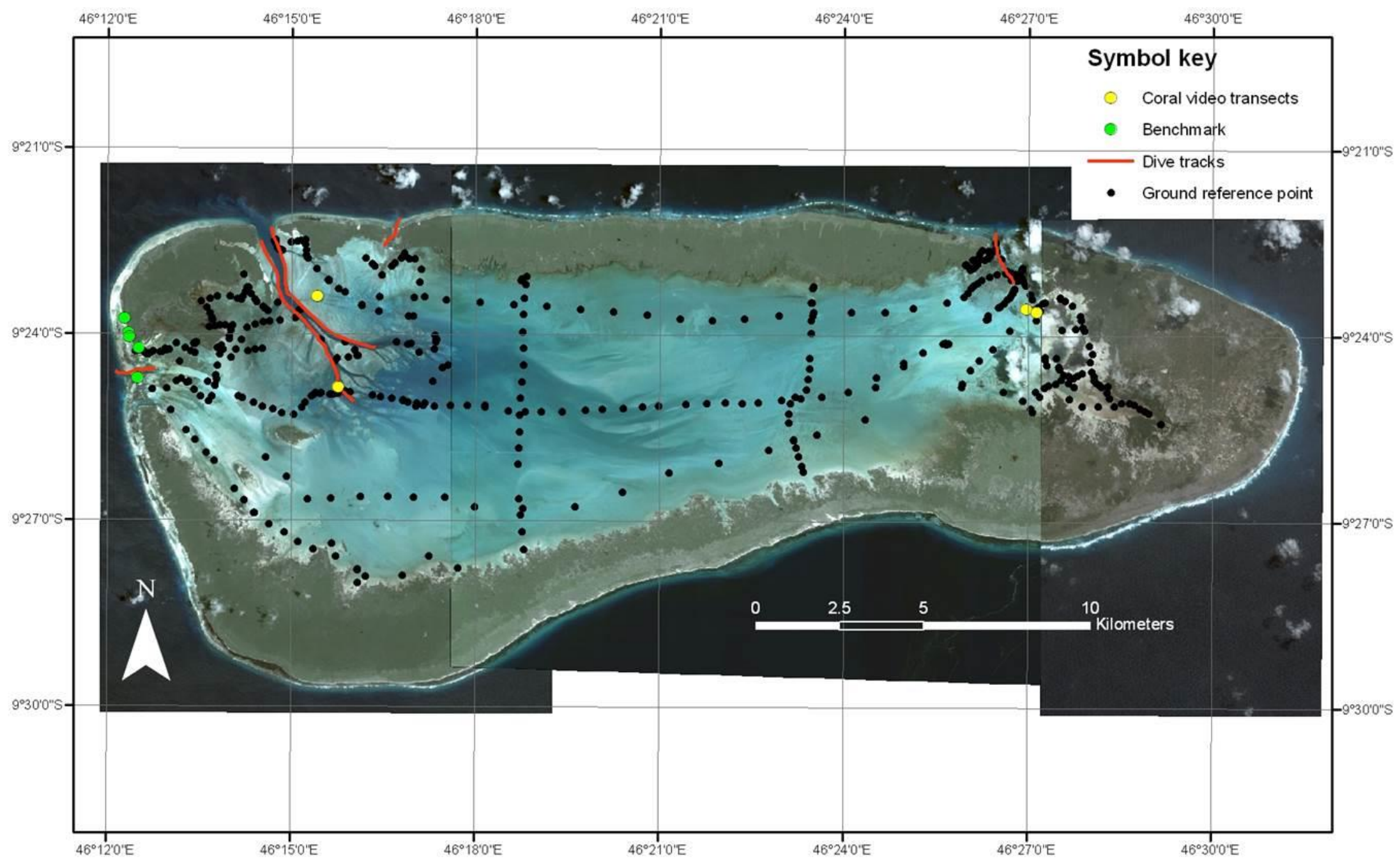

Figure 2. QuickBird imagery (2004 and 2006) showing locations of different survey techniques throughout Aldabra lagoon. 
In addition to the boat based observations, five SCUBA diving surveys were carried out using standard underwater video transect techniques to assess benthic community structure and species composition at key sites coincident with channels in the eastern and western sides of the lagoon (see Figure 2). Sites were selected that characterised the different coral and sediment biofacies provisionally identified by Farrow (1971) and Taylor (1978). Localised details of community composition were recorded for a belt transect along the reef measuring $30 \mathrm{~m}$ x $0.8 \mathrm{~m}$ at pre-determined depths. These quantitative surveys complemented the larger area surveys from the tethered video camera.

\section{Analysis of Ground Referencing Video Footage}

All underwater video footage collected from the boat and via scuba surveys was examined and the relative proportional cover, totalling $100 \%$, of one or more of the following 21 benthic classes was visually estimated: Bare carbonate sand; bedrock; coral rubble; coral rubble with turf; sponges; live coral; dead coral; coralline algae; Thalassodendron ciliatum; Thalassia hemprichii; Halodule sp.; Halophila ovalis; Enteromorpha sp.; Green algal turf; Hypnea esperi; Caulerpa spp.; Halimeda spp.; Hydroclathrus clathrus; algal mat; red fleshy algae; and Sargassum binderi. Percentage cover was chosen in order to standardise between differing areas covered by these distinctive and easily identifiable assemblages.

The dataset generated from video footage analysis was subsequently used to develop a classification scheme for the lagoon habitat map. A multivariate pair-wise Bray-Curtis cluster analysis was conducted on the coverage statistics (Bray and Curtis, 1957). This cluster analysis identified natural groupings in the samples which formed the basis of the distinct class groupings for the lagoon habitat map (Clarke and Warwick, 2001).

\section{Satellite Image Processing}

Three QuickBird images acquired between February 2004 and March 2006 provided synoptic coverage of the lagoon. Pre-processing procedures were applied to the three satellite images prior to classification. These procedures included an empirical line atmospheric correction (Karpouzli and Malthus, 2003); image masking to remove land areas; and water column correction (Lyzenga, 1981). A maximum likelihood unsupervised classification was performed on the three images to produce a single, classified thematic digital map composed of 30 classes. These were subsequently interpreted with respect to the ground-referencing dataset from the video footage records. A detailed description of the image processing techniques applied to generate the map can be found elsewhere (Hamylton et al., 2012b).

\section{Habitat Map Validation}

The resulting habitat map was validated using an independent set of 97 underwater photographs collected by Aldabra Research Station staff. These covered a representative range of benthic habitat types within the lagoon. Validation proceeded by overlaying each photograph onto the habitat map and recording the class identified on the map. In a separate validation exercise, all photographs were independently viewed and assigned a class with respect to the eight classes of the classification scheme. Class assignments arising from the classification algorithm and the separate validation exercise were compared and the overall accuracy was defined as the proportion of underwater photographs that were assigned the same class by both approaches (Congalton, 1991).

\section{Mapping the Bathymetry of Aldabra Lagoon}

\section{Establishing accurate vertical positioning}

Any work on lagoon water levels must be related to a common tidal datum, generally taken to be mean sea level. Peter Dale and a team of students from the Department of Geography, Cambridge University established a network of benchmarks around the seaward perimeter of the atoll rim in 1970, related to the Vidal benchmark established in 1967; the nearest surviving benchmark to the Vidal marker is station AB7 (Dale, 1972). A further benchmark was established in May 1975 by the UK Institute of Oceanographic Sciences (Main Tide Gauge IOS; see Pugh, 1978 for details). Finally, two benchmarks were emplaced by the Surveys Division of the Seychelles Government, by differential GPS methods, as 
part of the Seychelles Maritime Boundaries Project (pers. comm. Chang-Tave, 2009; Map Geosystems Report); these are known as 'Republic of Seychelles Survey Marker (GPS Control 1998) No. 1501 and No. 1502.'

This study reports the first inter-comparison of these different benchmarks around the Research Station on Aldabra. A base station was established at the Main Tide Gauge IOS benchmark and height differences between all benchmarks were determined by semi-automatic level surveys; in all cases, closure errors were $<0.007 \mathrm{~m}$ (Figure 3; Table 1).

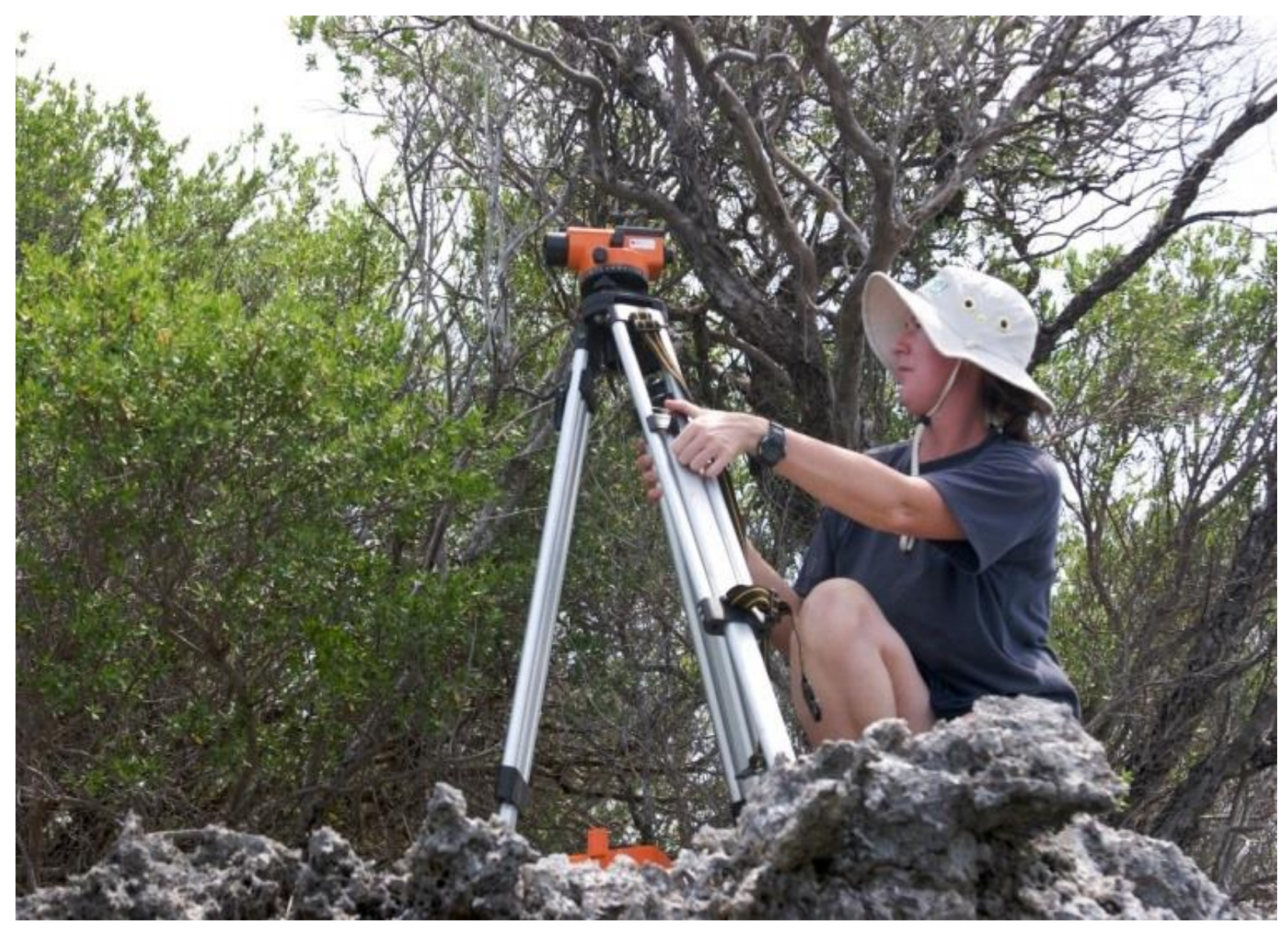

Figure 3. Conducting semi-automatic level surveys to calculate relative height differences between benchmarks. 
Table 1. Benchmark locations and heights above mean sea level relative to Main Tide Gauge IOS (Pugh, 1979), as surveyed in February 2009 and closed loop levelling results relating the IOS, 1502, 1501 and AB7 benchmarks.

\begin{tabular}{|c|c|c|c|}
\hline \multicolumn{4}{|l|}{ Aldabra Benchmark details } \\
\hline Benchmark descriptor & $\begin{array}{l}\text { Height }(\mathrm{m}) \\
\text { above Mean Sea } \\
\text { level }(\mathrm{msl})\end{array}$ & Source & Location \\
\hline Main Tide Gauge IOS & 3.697 & Pugh (1979) & $\begin{array}{l}23^{\circ} 44.74985 \mathrm{~S} \\
12^{\circ} 17.08629 \mathrm{E}\end{array}$ \\
\hline $\begin{array}{l}\text { Republic of Seychelles Survey } \\
\text { Marker } 1502\end{array}$ & 3.317 & & $\begin{array}{l}23^{\circ} 59.34979 \mathrm{~S} \\
12^{\circ} 20.89659 \mathrm{E}\end{array}$ \\
\hline $\begin{array}{l}\text { Republic of Seychelles Survey } \\
\text { Marker } 1501\end{array}$ & 3.457 & & $\begin{array}{l}24^{\circ} 2.956087 \mathrm{~S} \\
12^{\circ} 21.87775 \mathrm{E}\end{array}$ \\
\hline AB7 & 3.742 & Dale (1972) & $\begin{array}{l}24^{\circ} 13.39483 \mathrm{~S} \\
12^{\circ} 30.83472 \mathrm{E}\end{array}$ \\
\hline \multicolumn{4}{|c|}{ Relational heights between benchmarks } \\
\hline Closed Loop Survey & Distance / km & $\begin{array}{l}\text { Closure Error / } \\
\mathrm{m}\end{array}$ & $\begin{array}{l}\text { Relative Height } \\
\text { Difference }\end{array}$ \\
\hline IOS to 1502 & 1.0 & \pm 0.007 & $\begin{array}{l}\text { IOS is } 0.38 \mathrm{~m} \text { higher } \\
\text { than } 1502\end{array}$ \\
\hline 1502 to 1501 & 0.25 & \pm 0.005 & $\begin{array}{l}1501 \text { is } 0.14 \mathrm{~m} \\
\text { higher than } 1502\end{array}$ \\
\hline 1501 to $\mathrm{AB} 7$ & 1.1 & \pm 0.004 & $\begin{array}{l}\mathrm{AB} 7 \text { is } 0.285 \mathrm{~m} \\
\text { higher than } 1501\end{array}$ \\
\hline
\end{tabular}

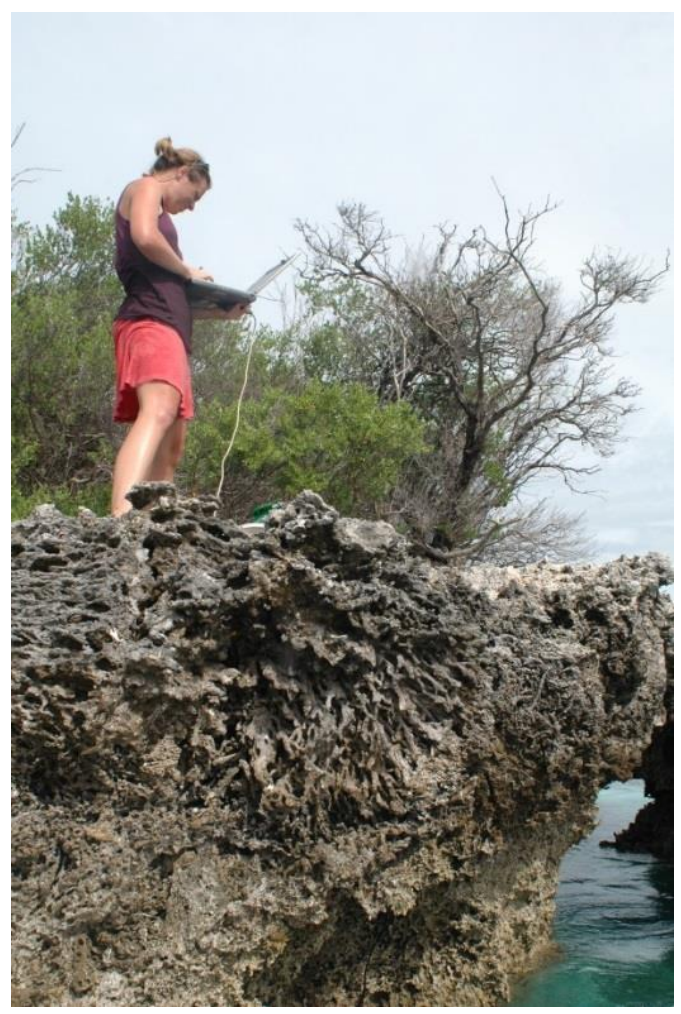

Figure 4. Downloading data logger readings of tidal cycle at Passe du Bois through the use of pressure transducer on the seabed. 
Interestingly, the difference in elevation between the height of $\mathrm{AB} 7$ from our surveys $(+3.742 \mathrm{~m}$ above mean sea level) and that derived from reference to the Vidal benchmark alone by Dale (1972; $+3.620 \mathrm{~m}$ ) is $0.122 \mathrm{~m}$. The difference in height between AB7 and the Vidal benchmark was not reestablished. We therefore take Dale's (1972; Table 1) height differential for this comparison; the Vidal mark is $1.67 \mathrm{~m}$ lower than AB7. Semi-diurnal tidal cycles were measured throughout the fieldwork period using a pressure transducer placed on the seabed in Passe du Bois, at the western end of Ilot Du Bois. Tidal fluctuation readings were recorded with a Campbell 21X Micrologger and downloaded every three days (Figure 4). The height of the sensor was established relative to the Vidal benchmark, thereby providing the means to relate the tidal measurements collected to a common island datum.

\section{Estimating Lagoon Depths from Satellite Images}

Two hundred and thirteen depth measurements were collected from the lagoon using a hand-held HawkEye single beam bathymetric sonar sounder and corrected to the common vertical datum of mean sea level as determined by field levelling and water depth measurements (see above). As with the ground referencing footage, the geographical position of each measurement was recorded by differential GPS on the boat (positional accuracy $\pm 0.2 \mathrm{~m}$ ).

A detailed description of the image processing associated with the bathymetric mapping has been published elsewhere (Hamylton et al., 2012a). A band ratio transformation was applied to estimate the water depth of each image pixel from the satellite images. This was based on the relationship between the ratio of the green $(560 \mathrm{~nm})$ and blue $(485 \mathrm{~nm})$ wavelength bands of the satellite image and water depth (Stumpf et al., 2003). Depth estimations from the resulting digital bathymetric map were then compared with an additional 188 point water depth measurements recorded in the field.

\section{RESULTS}

Eight habitat groupings emerged from the cluster analysis of the ground-referencing points at the $40 \%$ level of Bray-Curtis similarity. A habitat scheme was developed on the basis of these clusters, which became the key for the habitat map and these were aligned with the interpretations of classes produced by the image classification (Figure 5).

The spectral detail of the QuickBird images was sufficient to generate a preliminary lagoon classification of 30 classes, which was subsequently generalised into 8 classes (Figure 6). These aligned with the 8 natural groupings identified in the cluster analysis (Figure 5).

The two dominant classes mapped were "sparse macroalgae and seagrass assemblage on sand" and "dense macroalgal mat on sand", which covered $35 \%$ and $33 \%$ of the lagoon area respectively. Aside from algae and seagrasses, other notable habitat classes were bare carbonate sand $(17 \%$ of the lagoon area) and, around the periphery of the lagoon in association with fringing mangroves, finer sand with organic matter. The remaining classes of coral, coral rubble, bedrock and seagrass beds occurred in the vicinity of the channels, particularly the northern channels of Grande Passe in the west and Passe Houareau in the east (see Figure 7 for example photos).

Across all 8 classes, the digital map had an overall accuracy of $65 \%$. The main spectral confusion appeared to arise in distinguishing between macroalgae and seagrass, thus, when these classes were merged, the overall accuracy of the map improved to $72 \%$.

Estimates of lagoon floor elevation in relation to mean sea level ranged from -0.2 to $-30 \mathrm{~m}$. The deepest areas were associated with the channels, particularly Grande Passe in the northwest (Figure 8). Here, the channel subdivided into two main veins running into the lagoon centre to create a deeper dish (6-8 m deep) on the western side of the lagoon. Much of the lagoon in the east and around the rest of the periphery was shallow $(<3 \mathrm{~m})$. The shallowest areas of the lagoon were along the shorelines marking the inner margin of the southern lagoon boundary. 


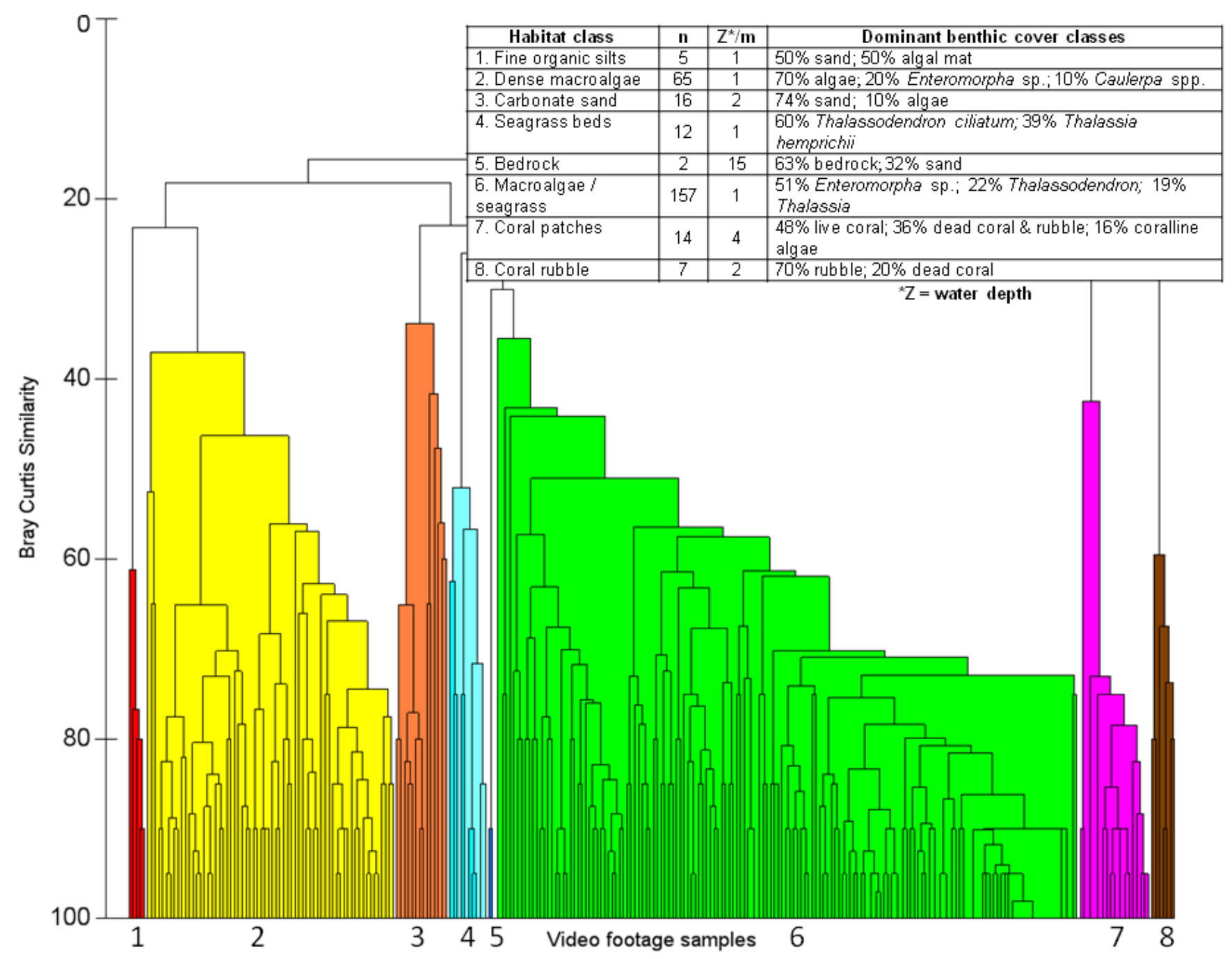

Figure 5. Hierarchical cluster analysis of lagoon benthic surface cover recorded in 486 snapshots of video footage from the lagoon floor. Eight clusters were defined at the $40 \%$ similarity level, which became the classification scheme for the lagoon map. 


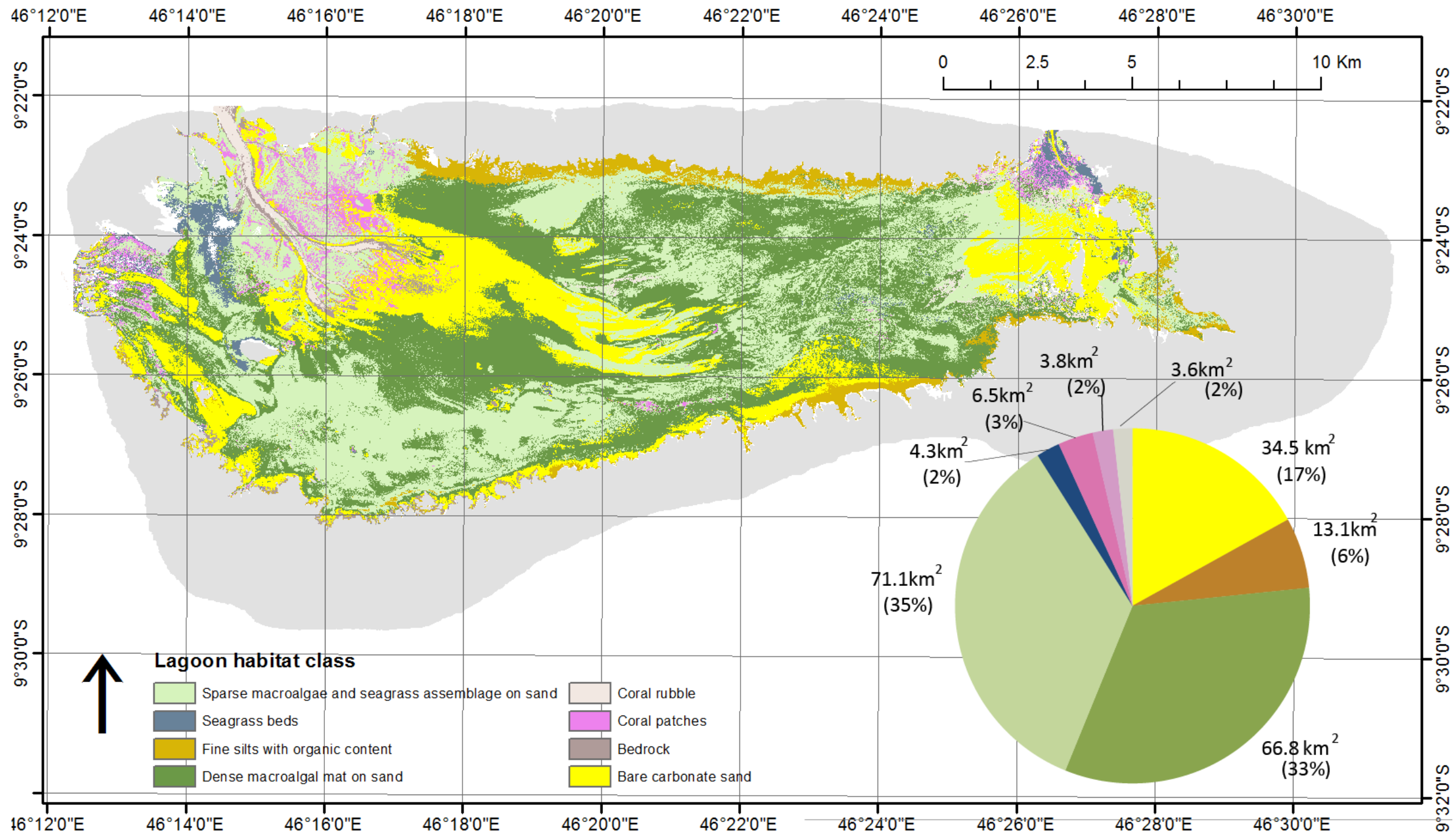

Figure 6. Habitat map of Aldabra Lagoon showing 8 classification categories with indicative proportional covers. 


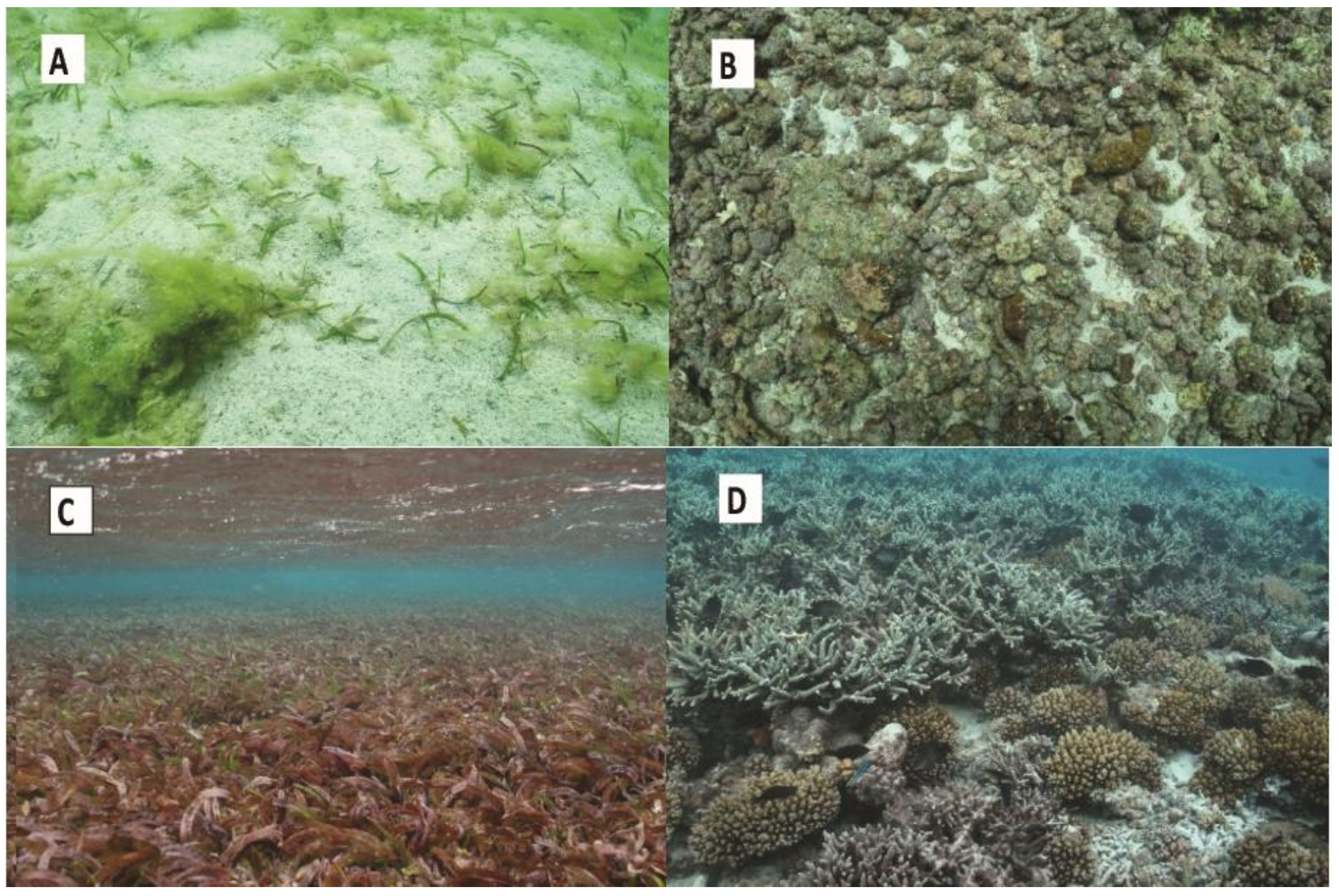

Figure 7. Examples of lagoon map classification scheme A) Sparse macroalgae and seagrass assemblage on sand; B) Coral rubble; C) Seagrass beds; D) Live coral. Photos: A. Hagan. 


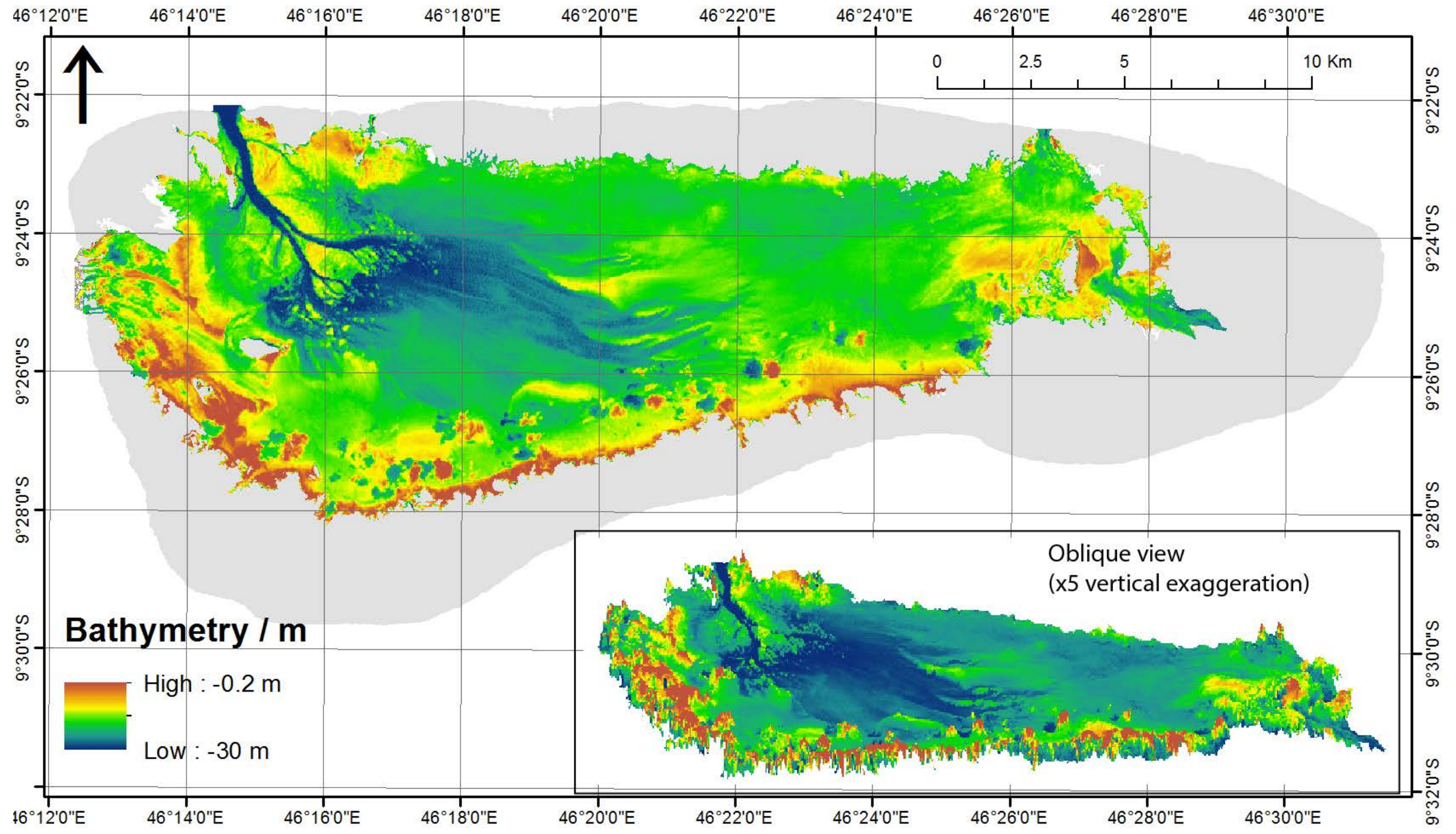

Figure 8. Bathymetric map of the Aldabra lagoon floor from above and at an oblique angle (inset). 


\section{DISCUSSION}

Previous descriptions of the nature of lagoon substrates, by Farrow (1971), Taylor (1978) and Stoddart (1984) have been highly generalized, often stressing the uniformity of cover types. We suggest that these descriptions are an artefact of the difficulty in studying the nature of the Aldabra lagoon floor and its spatial variability. Even when simplifying the 21 benthic categories into 8 classes, the detailed character of the lagoon substrate is apparent (Figure 6).

The two dominant classes mapped "sparse macroalgae and seagrass assemblage on sand" and "dense macroalgal mat on sand" collectively cover $68 \%$ of the lagoon area. These occur mainly on the shallower expanses of lagoon floor that are situated further away from the main channels, and are not therefore subject to the increased hydrodynamic flows that drain the lagoon each tidal cycle.

Aldabra Atoll would greatly benefit from further application of modern mapping techniques, particularly a LiDAR survey incorporating both the terrestrial and marine environments, and the establishment of regular, repeated drone surveys to monitor areas of management interest. One such area emerging from the present study would be the north western lagoon along Grande Passe. This, the largest (widest and deepest) channel connecting the lagoon to the open ocean, experiences substantial currents over the course of each tidal cycle, and supports a relatively high level of benthic diversity, including diverse coral and seagrass assemblages. This situation appears largely unchanged since 1978, when Taylor $(1978,19)$, described the lagoon floor as 'generally rock bottomed, but may have a thin cover of fine sand or silt. Near the channels the hydrodynamic situation is much more complex and a mosaic of habitats is developed, with accumulations of sand, beds of marine angiosperms, coral patches and mixed sand and coral areas'.

A further set of tidal measurements at a single point on Aldabra would be of limited value. The problem of tidal variations around the Atoll and within the lagoon needs to be addressed using modern scientific equipment and technical skills, building on the pioneering efforts of Farrow and Brander almost half a century ago. The logistical problems are immense but the potential benefits are equally great. All existing observations in the lagoon come from recordings in the period of the SE Trade Winds which may result in the setup of considerable water surface slopes across the lagoon towards the north, conditions which are unlikely to be replicated at other times of the year (and therefore of interest in themselves). Ideally we would like to model water surface topography at spring, neap and mid tides, and then derive current velocity fields, the relative contribution of the various channels, and water residence times. This would then allow the calculation of sediment and nutrient budgets for the entire lagoon, and, for example, help understand mangrove response to different tidal conditions.

The threat of climate change has emerged since much of the early work that was carried out at Aldabra. Indeed, coral bleaching and ocean acidification could potentially have a large influence within the lagoon. Surveys following the 1997/98 Indian Ocean warming event found that lagoonal patch reefs and individual heads of massive coral species in the lagoon at Aldabra displayed only limited bleaching (Spencer et al., 2000). Deeper waters appeared to suffer higher levels of coral mortality, e.g. $66 \%$ at $10 \mathrm{~m}$ depth and $38 \%$ at $20 \mathrm{~m}$ depth, with limited recovery of hard corals and no substantive macroalgal cover increases some five years after the event (Stobart et al., 2005). With annual average sea surface temperature rates of warming of $0.75^{\circ} \mathrm{C}$ for this ocean region (Hughes et al., 2017; Lough, 2012) this threat emphasises the value of detailed maps as a record for comparison to ascertain changes in benthic communities. Broadly, Aldabra offers an excellent location at which to assess the substantial biodiversity of a near-pristine tropical marine ecosystem, providing both i) a benchmark of good coral reef health in a region (northern Madagascar, Comores and East Africa) being heavily exploited and impacted by human pressures and ii) an anthropogenically undisturbed system in which it should be possible to monitor ecological responses to changes in sea surface temperature and irradiance.

In 1978, John Taylor speculated 'it might be predicted that a progressive increase in sea level will deepen and enlarge the present lagoon, resulting in an improved circulation and sedimentation and encouraging a greater diversity of lagoon habitats' (Taylor, 1978, 25). For the period 1950-2001, reconstructed sea level rise at Port Louis, Mauritius $\left(57^{\circ} 30^{\prime} \mathrm{E} 20^{\circ} 09^{\prime} \mathrm{S}\right)$ and Rodrigues $\left(63^{\circ} 25^{\prime} \mathrm{E} 19^{\circ} 40^{\prime} \mathrm{S}\right)$ was 1.5 and $1.3 \mathrm{~mm}$ a-1 respectively (Church et al., 2006). However, the instrumented record shows 
considerable inter-decadal variability; thus at Port Louis a period of sea level rise $(+3.7 \pm 1.5 \mathrm{~mm} \mathrm{a}-1$, 1986-2000) was preceded by a phase of sea level fall ( $-1.9 \pm 1.5 \mathrm{~mm} \mathrm{a}-1,1953-1964)$ (Church et al., 2006). Further north, at Pointe La Rue, Mahé $\left(55^{\circ} 32^{\prime} \mathrm{E} 4^{\circ} 40^{\prime} \mathrm{S}\right)$ the instrumented record shows sea level rise but with very high variability $\left(+5.6 \pm 6.6 \mathrm{~mm}\right.$ a-1, 1993-2000) $\left.4^{\circ} 40^{\prime} \mathrm{S}\right)$; the $1950-2001$ relative trend at this site was $0.5 \mathrm{~mm} \mathrm{a}-1$ (Church et al., 2006). However, recent studies of the decadal rate of sea surface height $(\mathrm{SSH})$ change north of $5^{\circ} \mathrm{S}$ have shown a switch from this low rate of long-term rise to a rise of ca. $6 \mathrm{~mm} \mathrm{a}-1$ in the period 2004-2013 (Thompson et al., 2016). It is in these contexts that lagoonal bathymetry and habitat coverage will need to be re-assessed over future decades.

\section{ACKNOWLEDGEMENTS}

For logistical and funding support we thank the Seychelles Islands Foundation, Seychelles Environment Trust and the Cambridge Coastal Research Unit. We are also grateful to Naomi Doak, Robyn James, University of Queensland, and Lilian Pintea, Director of Conservation Science, Jane Goodall Institute, for the acquisition of Quickbird imagery. We thank the Seychelles Bureau of Standards for permission to undertake this work.

\section{REFERENCES}

Andréfouët S., Chagnaud N. and Kranenburg C. 2009. Atlas of western and central Indian Ocean coral reefs. Centre IRD de Nouméa, Nouméa, Nouvelle-Calédonie, CD-ROM.

Bray J. R. and Curtis J. T. 1957. An ordination of the upland forest communities of southern Wisconsin. Ecological Monographs 27:325-349.

Church J. A., White N. J. and Hunter J. R. 2006. Sea-level rise at tropical Pacific and Indian Ocean islands. Global and Planetary Change 53: 155-168.

Clarke K. R. and Warwick R. M. 2001. Change in marine communities: an approach to statistical analysis and interpretation. 2nd ed. Plymouth, UK: Primer-E.

Congalton R. G. 1991. A review of assessing the accuracy of classifications of remotely sensed data. Remote Sensing of Environment 37:35-46.

Drew E. A. 1977. A photographic survey down the seaward reef-front of Aldabra Atoll. Atoll Research Bulletin 193:1-17.

Farrow G. and Brander K. 1971. Tidal studies on Aldabra. Philosophical Transactions of the Royal Society of London. Series B, Biological Sciences:93-121.

Goldberg W. 2016. Atolls of the world: revisiting the original checklist. Atoll Research Bulletin, 610.

Hamylton S., Spencer T. and Hagan A. 2012a. Spatial modelling of benthic cover using remote sensing data in the Aldabra lagoon, western Indian Ocean. Marine Ecology Progress Series 460, 35-47.

Hamylton S. M., Hagan A. B. and Doak N. 2012b). Observations of dugongs at Aldabra Atoll, western Indian Ocean: lagoon habitat mapping and spatial analysis of sighting records. International Journal of Geographical Information Science 26:839-853.

Hughes T. P., Barnes M. L., Bellwood D. R., et al. 2017. Coral reefs in the Anthropocene. Nature 546:82-90.

Karpouzli E. and Malthus T. 2003. The empirical line method for the atmospheric correction of IKONOS imagery. International Journal of Remote Sensing 24:1143-1150.

Lough J. 2012. Small change, big difference: sea surface temperature distributions for tropical coral reef ecosystems, 1950-2011. Journal of Geophysical Research: Oceans 117.

Lyzenga D. R. (1981) Remote sensing of bottom reflectance and water attenuation parameters in shallow water using aircraft and Landsat data. International Journal of Remote Sensing 2:71-82.

Macnae W.1971. Mangroves on Aldabra. Philosophical Transactions of the Royal Society of London. Series B, Biological Sciences 260:237-247. 
Pugh D. 1979. Sea levels at Aldabra Atoll, Mombasa and Mahé, western equatorial Indian Ocean, related to tides, meteorology and ocean circulation. Deep Sea Research Part A. Oceanographic Research Papers 26:237-258.

Pugh D. and Rayner R. 1981. The tidal regimes of three Indian Ocean atolls and some ecological implications. Estuarine, Coastal and Shelf Science 13:389-407.

Spencer T., Teleki K. A., Bradshaw C., et al. 2000. Coral bleaching in the southern Seychelles during the 1997-1998 Indian Ocean warm event. Marine Pollution Bulletin 40:569-586.

Stobart B., Teleki K., Buckley R., et al. 2005. Coral recovery at Aldabra Atoll, Seychelles: five years after the 1998 bleaching event. Philosophical Transactions of the Royal Society of London A: Mathematical, Physical and Engineering Sciences 363:251-255.

Stoddart D. 1979. Aldabra and the Aldabra research station. Philosophical Transactions of the Royal Society of London. Series B, Biological Sciences: 3-10.

Stoddart D. 1984. Coral reefs of the Seychelles and adjacent regions. In: Stoddart DR (eds) Biogeography and Ecology of the Seychelles Islands. W. Junk: The Hague, 63-81.

Stoddart D. and Ferrari J. 1983. Aldabra atoll: a stunning success story for conservation. Nature Resources 19: 20-28.

Stumpf R. P., Holderied K. and Sinclair M. 2003. Determination of water depth with high-resolution satellite imagery over variable bottom types. Limnology and Oceanography 48:547-556.

Taylor J. D. 1978. Faunal response to the instability of reef habitats: Pleistocene molluscan assemblages of Aldabra Atoll. Palaeontology 21:1-30.

Thompson P., Piecuch C., Merrifield M., et al. 2016. Forcing of recent decadal variability in the Equatorial and North Indian Ocean. Journal of Geophysical Research: Oceans 121:6762-6778. 



\title{
THE STODDART EXPEDITION TO THE NORTHERN GREAT BARRIER REEF 1973: A VOYAGE OF DISCOVERY
}

\author{
J. E. N. VERON ${ }^{1}$
}

\section{BACKGROUND}

I first met David Stoddart in June 1973 on the Marco Polo, a cruise ship chartered for the Second International Coral Reef Symposium. During that brief meeting Stoddart suggested I should seek permission to take James Cook University's new research vessel James Kirby to the far northern Great Barrier Reef (GBR) as the third phase of what was universally to become known as 'The Stoddart Expedition'. Stoddart's proposal became reality in late November of that year, the first expedition ever to explore the 1,000 km-long complex of reefs of the far northern GBR (Figure 1). This was to be the most important expedition of discovery in the lives of most, if not all, participants of that expedition.

Many data-collecting projects were planned and three main geographic targets were selected. These, in reverse chronological order, were: (1) reefs later to become known as the 'deltaic reefs' of far northern GBR (2) Raine Island and (3) the northern 'ribbon reefs' which ran parallel to the abyssal waters of the Queensland Trough. Although this article focuses on the last of these places it is important to note that next to nothing was known about any of them. There were no relevant publications and navigational charts had very little reliable information. This made the expedition one of exceptional discovery.

\section{The Deltaic Reefs}

The deltaic reefs are 140-150 km from the mainland coast of Australia, almost due east of Cape York (Figure 2). The continental shelf between the reefs and the mainland is still poorly charted but seldom appears to be much more than $30 \mathrm{~m}$ deep and contains large numbers of patch reefs. Despite their river delta-like appearance in World War II aerial photographs, these reefs turned out to be a wide 100 $\mathrm{km}$-long platform of solid limestone (Veron, 1978). During the expedition two reefs were selected for study; one of those reefs 'deltaic reef 2' is shown in Figure 3. The channels which created the deltaic pattern had vertical sides and deep flat floors clearly formed by tide-driven erosion from sand and rubble. We estimated that currents on ebb tides reached $3.5 \mathrm{~m} / \mathrm{sec}^{-1}$, a speed only rivalled at or within the smaller deltaic reefs of the southern GBR (Maxwell, 1968). Despite the dramatic appearance of these formations the northern deltaic reefs are seldom visited as they lack safe anchorages and are hazardous for divers.

\section{Raine Island}

This is now one of the best-known places of the entire GBR. It is also one of the most isolated, being $127 \mathrm{~km}$ east of the Cape York coast and one of very few islands on the outer barrier reef (Figure 2). However, before our expedition we discovered that it had a beacon on it built by convicts in 1844, making it the oldest European structure in tropical Australia. On arrival, we soon found the cay had more important attributes, the most significant being a turtle rookery. During the first night we counted 280 green turtles coming up the beach to nest, making the island (only 32 ha in area) one of the biggest turtle rookeries in the world (Figure 4). This discovery was dwarfed a year later when we counted nearly 12,000 turtles in a single night, a world record for green turtles. Our reporting of these findings led to thestart of the Raine Island Corporation that gave the island the strictest conservation protection in all Australia, pre-

\footnotetext{
${ }^{1}$ Coral Reef Research, 10 Benalla Road, Oak Valley, Townsville Qld 4811, Australia.
} 
dating the declaration of World Heritage status of the Great Barrier Reef by nearly a decade. Raine Island is also the most important seabird rookery in the World Heritage Area with 16 species breeding on the island including the critically endangered herald petrel.

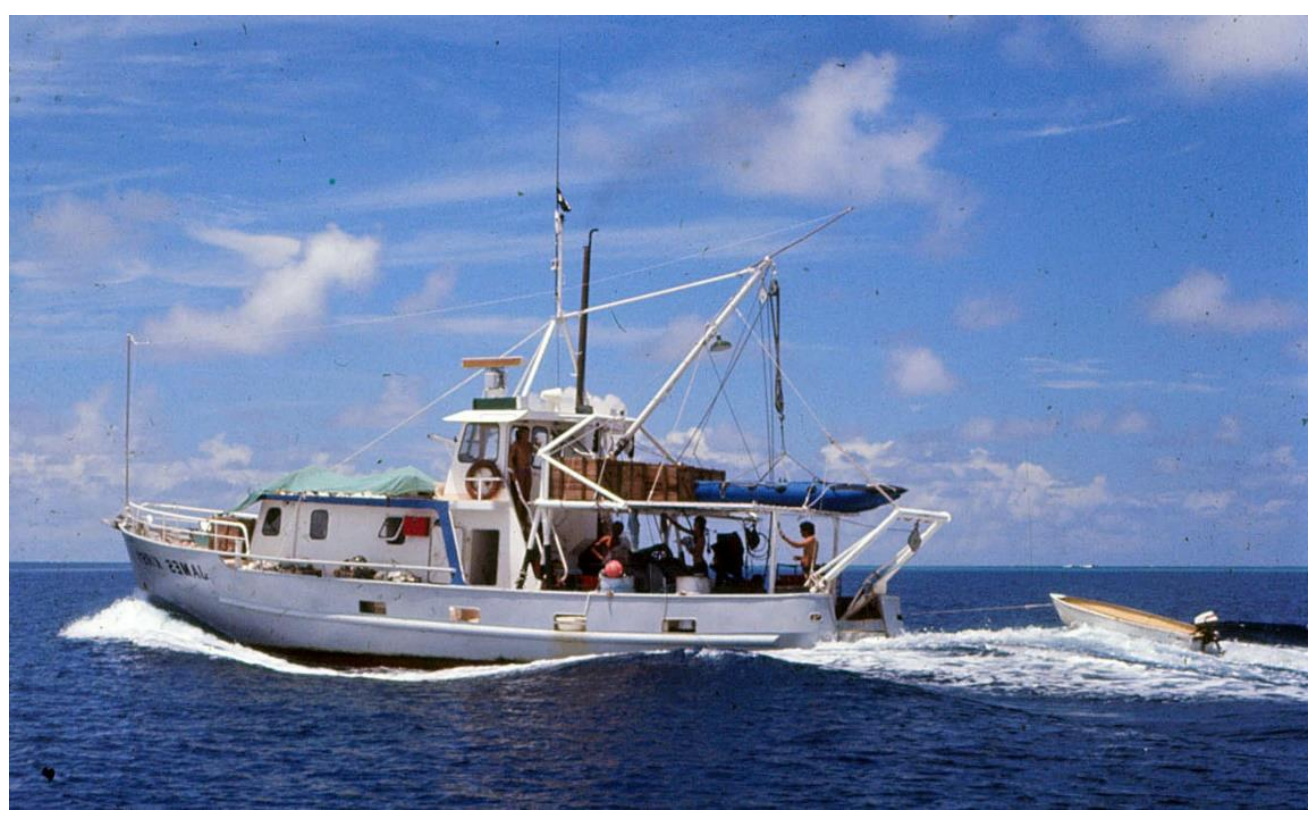

Figure 1. The James Kirby on its maiden voyage to the most northerly sector of the Great Barrier Reef during Phase III of the Stoddart Expedition November 1973.

Figure 2. Northern sector of the Great Barrier Reef showing location of sites mentioned in text. Distance from Lizard Island to Raine Island is $365 \mathrm{~km}$. PNG = Papua New Guinea. Google Earth Image, 14 December 2015.

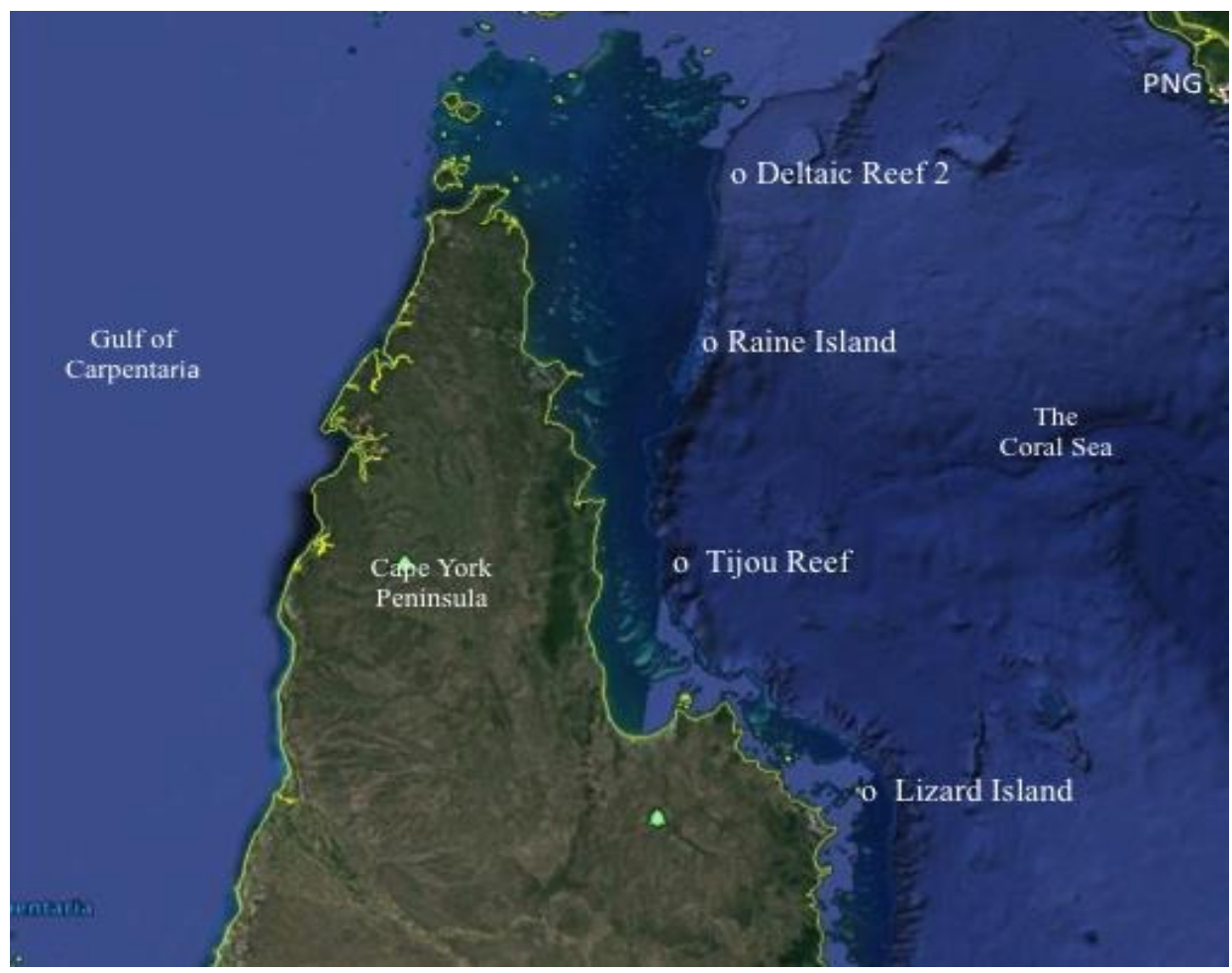




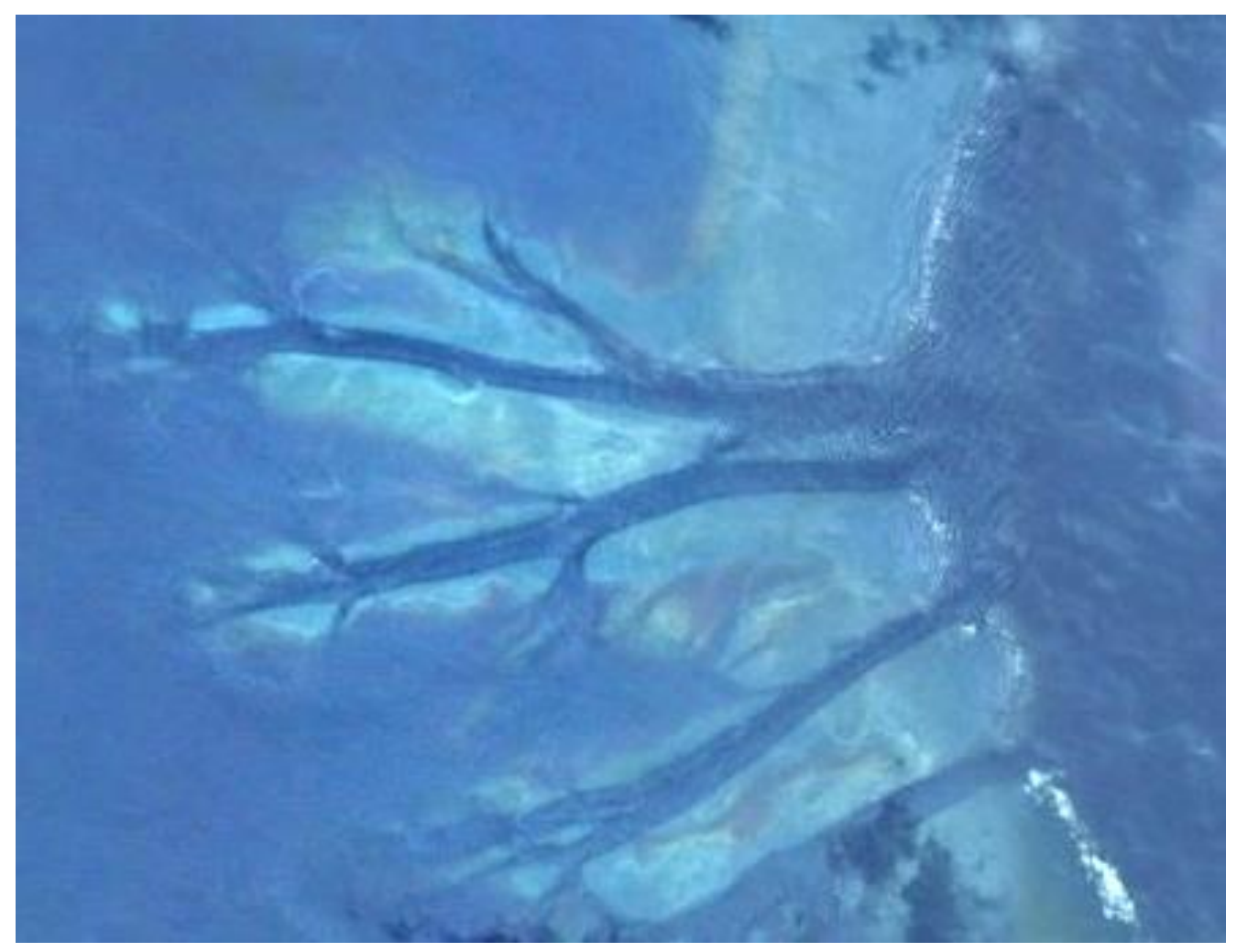

Figure 3. Deltaic reef 2. 10 46' S; 143ํ5' E. Google Earth Image, 14 December 2015.

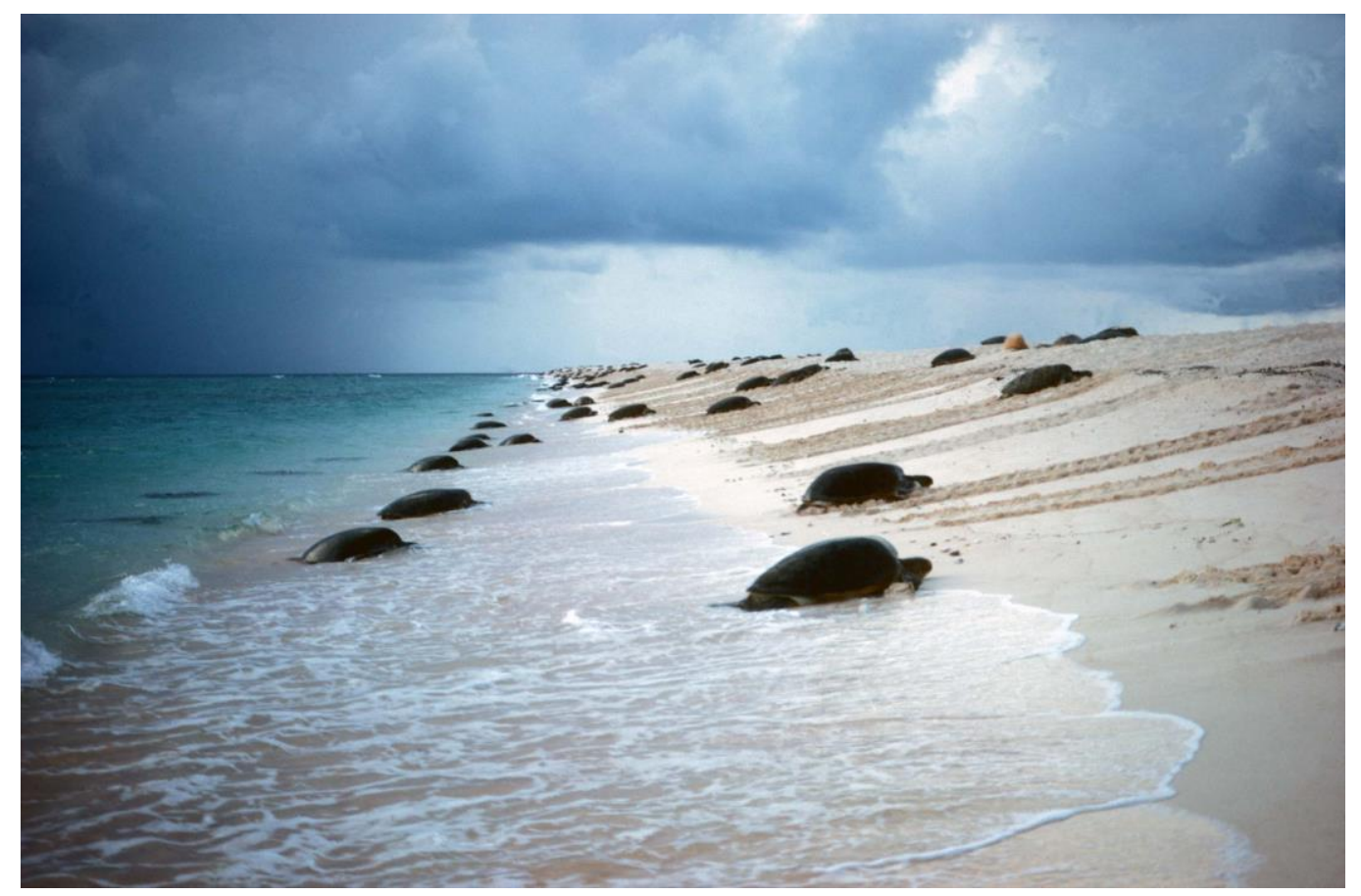

Figure 4. Green turtles coming ashore on Raine Island to lay eggs, December 1974. Photograph: Len Zell. 


\section{The Ribbon Reefs}

Almost nothing was known about the ribbon reefs (Figure 5) of the far northern GBR at the time of the Expedition. After much deliberation, Tijou Reef, $46 \mathrm{~km}$ offshore (Figure 2) was selected as a prime target, partly because it was the thinnest and longest ( $26 \mathrm{~km}$ between passages) of all the ribbon reefs, but mainly because a broad-scale bathymetric chart of the Coral Sea suggested that it had the closest proximity to the Queensland Trough. At that time there had been many theories about the origin and age of the GBR, most based on hypotheses stemming from Darwin's theory about the origin of atolls. In 1937 some geologists from the University of Queensland had tried to prove or disprove Darwin's theory by drilling a hole at Heron Island. When this did not work out they tried to drill further holes in and around some ribbon reefs. These also failed. In hindsight this was fortunate because there was a lot of interest in these drillings and newspapers of the time would surely have pronounced Darwin wrong, in line with the dim Christian-dominated view most people had about his theory of evolution. Nevertheless, post-war theories abounded, the dominant view being that the GBR was post-Pleistocene in age (Jones, 1966) a view later modified by several authors (Harvey, 1984).

\section{DISCUSSION}

In my view, the many hypotheses espoused over this period could only be sustained if the ribbon reefs were structurally independent of the Queensland Trough as it would be impossible for a reef line to form on an erosional shelf of soft substrate that sloped down into the Trough. Our charts showed that the substrate west of the ribbon reefs was shallow and uniform in depth, but they had nothing to say about the substrate east of the reefs.

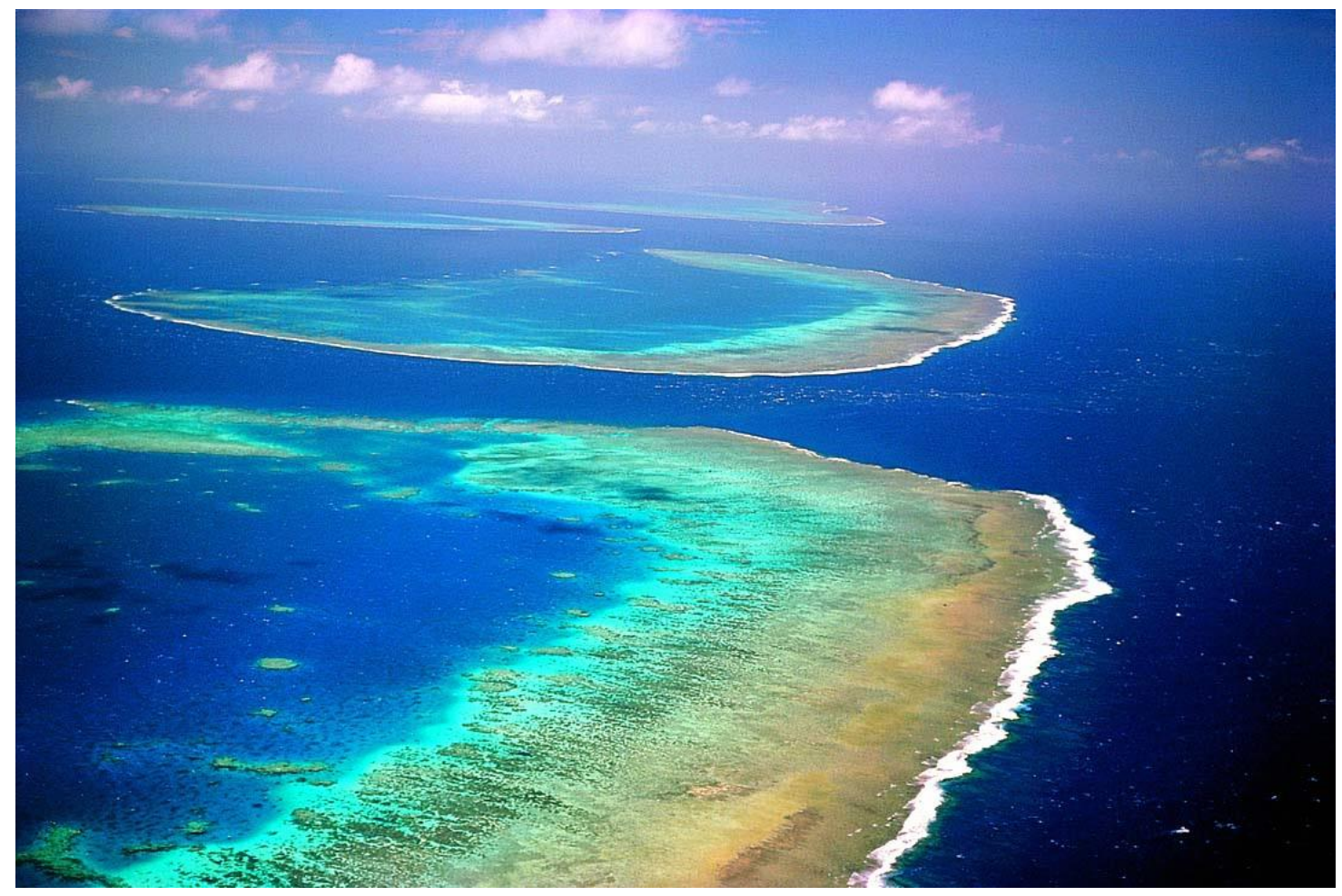

Figure 5. Ribbon reefs along the outer barrier of the Great Barrier Reef. The outer face (right) plunges into the Queensland Trough. The reef front is wave-hammered for most of the year. Photograph: author. 
Our first dive on the outer face of Tijou Reef, the first dive ever made on the outer face of a ribbon reef, was exceptionally revealing as we could see that the reef face plunged steeply down to a depth well below that visible using scuba. We then verified this slope was about $45^{\circ}$ using the James Kirby's echo sounder and a measuring line from the reef edge to the boat. The outer face of Tijou Reef and the western edge of the Trough were indeed the same structure.

This view was later modified when diving on the outer face of more northerly reefs where we found that a narrow ridge at depths of 40-70 m commonly parallels the reef front. To this day this ridge, now studied in detail using high resolution three dimensional bathymetry (Beaman, 2016), is usually described as a line of 'drowned' (meaning dead) reefs. However, we observed abundant coral on them using scuba and confirmed this by taking dredge samples of living corals from depths of up to $100 \mathrm{~m}$. Today it seems remiss that our findings were not published but at the time there were so many interesting findings, including others not mentioned here, that they formed a string of independent observations isolated from each other and from any published science.

Not long after the Stoddart Expedition was over, geologists again began taking deep cores from the Great Barrier Reef in what developed into the biggest single project ever undertaken on it. This work resulted in two basic notions about the age of the GBR, firstly that it is wedge-shaped, being thicker in the north because it was older in the north and secondly that it was very young as reefs go (Davies et al. 1989). Being wedge-shaped? It is as thick as the distance between bedrock and the ocean surface, something that has nothing to do with age. And being young? This work came to a much dramatized climax in 2001, when an international drilling consortium, using a 50 tonne drill, announced that the central Great Barrier Reef was a "baby" - had started growing 600,000 $\pm 280,000$ years ago - a conclusion endorsed by many reef geologists (International Consortium for Great Barrier Reef Drilling, 2001).

In 2008, I made the case for the GBR to be at least Early Miocene in age (Veron, 2008), something I had been mulling over ever since the Expedition. In briefest summary the main points were:

(1) The argument that if pre-Pleistocene reef isn't there now it never was there is not a good one for a continental coast that has been stable, and not sinking, throughout most if not all the Cenozoic Era.

(2) The outer face of the northern ribbon reefs and the western edge of the Queensland Trough are one and the same. From all we know of reef growth, it is hard to imagine how the one could have preceded the other.

(3) Miocene reef limestone occurs in the northern Coral Sea, including the far northern GBR.

(4) Extensive outcrops of reef limestone of all Cenozoic epochs from Late Eocene to present occur in northern Papua New Guinea.

(4) Miocene reef limestone occurs in northern New Zealand.

(5) Reefs, on both the eastern and western Australian coasts, occur well south of the position the GBR had during Early Miocene.

To my mind these facts beg the question: if there was so much Miocene reef development in the region of northern Greater Australia (Australia and New Guinea combined), why would the GBR not have developed at this time? One essential ingredient to the answer was missing until the 1990s: it was not known how corals dispersed (reviewed by Veron, 1995). We now know that coral larvae can make long distance migrations, so much so we can confidently surmise that they were capable of reaching the whole of tropical and subtropical Australia from Indonesia at all times from Early Oligocene on.

\section{CONCLUDING COMMENT}

This article is not a review of the origin of the Great Barrier Reef for there is now a host of publications relevant to this subject. Even so, these deal with detail rather than any overriding hypothesis. Its purpose is to acknowledge the fact that my view of the age of the GBR, be it correct or not, originated from the Stoddart Expedition and thus vicariously from Stoddart himself. This extraordinary man has been the seed of many such schools of thought. Like so many other scientists, I have much to thank him for and so has the broader scientific community. 


\section{REFERENCES}

Beaman, R. J. (2016) www.deepreef.org

Davies, P. J., Symonds, P.A., Feary, D.A and Pigram, C. J., 1989. The Evolution of the Carbonate Platforms of Northeast Australia. In: Controls on Carbonate Platform and Basin Development. Society of Economic Paleontologists and Mineralogists Special Publication 44:233-258.

Harvey, N. 1984. A century of ideas since Darwin: evolution of the Great Barrier Reef. Proceedings of the Royal Geographic Society of South Australia 81:1-21.

International Consortium for Great Barrier Reef Drilling, 2001. New Constraints on the Origin of the Australian Great Barrier Reef: Results from an International Project of Deep Coring, Geology 29:483-486.

Jones, O. A., 1966. Geological questions posed by the Reef. Australian Natural History, 15:245-249

Maxwell, W. G. H., 1968. Atlas of the Great Barrier Reef. Elsevier, New York: 260pp.

Veron, J. E. N., 1978. Deltaic and dissected reefs of the Northern Region. Philosophical Transactions of the Royal Society of London B Biological Sciences 284: 23-27.

Veron, J. E. N., 1995. Corals in Space and Time: the Biogeography and Evolution of the Scleractinia. Cornell University Press: $321 \mathrm{pp}$.

Veron, J. E. N., 2008. A Reef in Time: the Great Barrier Reef from Beginning to End. Harvard University Press: 289pp. 


\title{
UNDERSTANDING THE REASONS FOR THE REORIENTATION OF HERON ISLAND, A CORAL SAND CAY, GREAT BARRIER REEF, AUSTRALIA
}

\author{
PETER G. FLOOD ${ }^{1}$
}

\begin{abstract}
Heron Island is one of the best-known coral cays on the Great Barrier Reef. It was first mapped by J. A. Steers in 1936, and it has been the subject of several detailed studies concerning its erosion and reorientation during the past four decades in response to changing environmental conditions, climate variations, boat harbour dredging and spoil dump behaviours. Shoreline changes on Heron Island have been described in several articles and they have also been compared with changes on other cays of the Capricornia section of the Great Barrier Reef (GBR). These analyses have shown that the variations in the amount of erosion or accretion of the beach on Heron Island is about half that of similar sized cays in the Capricorn Group. However, the western end of Heron Island has experienced significant human interferences that have impacted the shape of the cay. Monitoring the shape of Heron Island has shown that the cay now has a shape different to many uninhabited coral cays in the region, all of which share similar geographical settings, implicating human interference with the island's longshore sand transport system. This difference results from the construction of rock and timber retaining walls, the dredging of the boat harbour and sediment movement of the dredge spoil. These impacts have outweighed those of natural processes such that Heron Island should not be considered in studies of cay shape and change in response to climate change and other environmental processes.
\end{abstract}

\section{INTRODUCTION}

I was first introduced to the Great Barrier Reef (GBR) in 1968. The years 1970-1971 were spent living in Cairns and visiting the coral cays of that region. In 1972, I commenced PhD studies at the University of Queensland and later that year visited Heron Island for the first time. That visit raised questions about the factors controlling the shape of Heron cay and the impacts that Tropical Cyclone (TC) Emily had made on the distribution of the reef top sediments described some 10 years earlier by Maxwell et al. (1961). In the intervening decade, when black and white vertical aerial photography of the GBR was in its infancy, Heron Island had been photographed in 1959, 1964, 1969, and 1972. These photographs provided data for the initial analysis of sand movements on Heron Island (Flood, 1974) as well as for a comparative analysis of the cays of the Capricorn and Bunker Groups (Figure 1). Throughout the 1980's studies of changes to the Heron Island shoreline continued (e.g., Flood, 1986; Flood, 1988). During this time effects of engineering and infrastructure development on coral cay behaviour were introduced (e.g., Gourlay and Flood, 1981; Gourlay, 2011) and later how the 1987 spoil dump affected the shoreline sediment transport system at the western end of the island (Gourlay and Jell, 1993). The latest visit by the author to Heron Island was in 2012 as part of an ongoing longitudinal study of the shoreline movements and analysis of coral cay stability. One aim has been to achieve a milestone for Heron Island comparable to that of David Stoddart detailing 45 years of change on Low Isles and Three Isles in the northern GBR (Stoddart et al., 1978). Google Earth images now provide an ongoing source of data to update the changes in the shape of Heron Island.

\footnotetext{
${ }^{1}$ School of Geoscience, University of Sydney, NSW 2006, Australia
} 


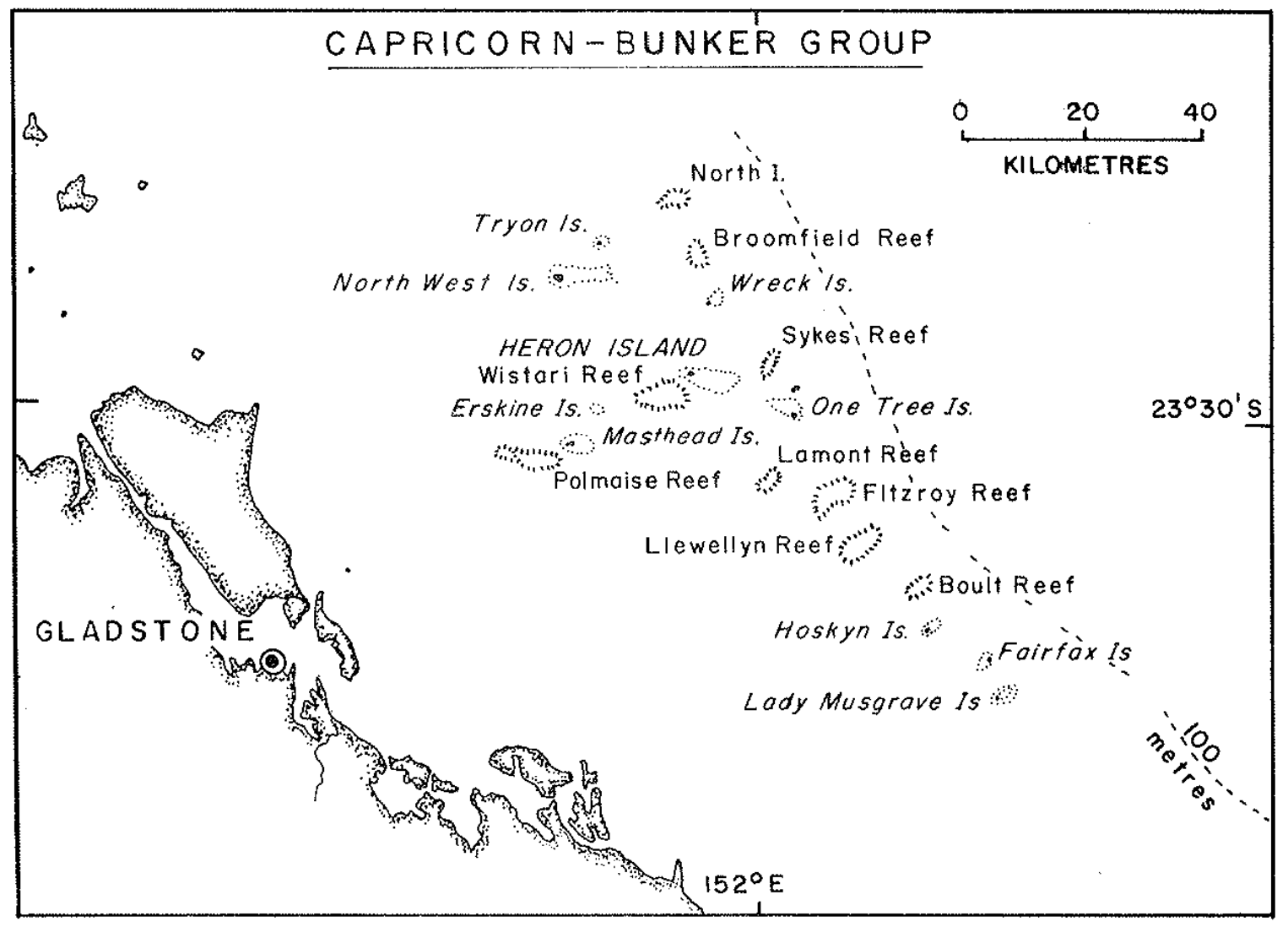

Figure 1. Location of Heron Island and adjacent coral cays and reefs in the Capricorn-Bunker Section of the Great Barrier Reef.

\section{CAPRICORN - BUNKER GROUP AND HERON ISLAND}

The Capricorn - Bunker Group comprises the southernmost reefs of Australia's Great Barrier Reef Province. The reefs are located on the mid- to outer- shelf 50-80 km from the Queensland coast and 10-20 km west of the shelf edge. Water depths are 35-60 m deepening eastward. Spring tide ranges from 2.0-3.3 $\mathrm{m}$ and neaps from $0.8-1.6 \mathrm{~m}$. The flood tide sets to the west and ebb to the east. Prevailing wind in the region is the SE trade wind that blows for approximately 70 per cent of the time. During the summer months NE to NW winds are experienced and occasional tropical cyclones.

The islands of the Capricorn -Bunker Group display a variety of sizes, shapes, vegetation cover and habitation. Full descriptions, maps and vertical photographs of all of the islands in the Group are included in an early edition of the Atoll Research Bulletin (see Flood, 1977). Within the Group there are three island sediment types - coarse coral shingle islands, mixed shingle-sand islands and sand cays. This paper is concerned with the sand cays of which the best known is Heron Island. Steers $(1937$, p. 9) noted that the sand cays in the Capricorn-Bunker Group possessed 'so great a likeness physiographically between all these islands that a description of one almost applies to all'. Such 'likeness' is not evident in the size of the sand cays or of the reef platforms on which they sit (see Table 1) although there are similarities in their shape, position on the reef and geographical setting. For example all of the sand cays are located toward the leeward (western) margin of the reef top and cover a small fraction, from 1 to 12 per cent, of the reef top area. Locally generated trade wind waves and ocean swell from the SE quadrant 
refract around the reefs and produce lateral sand transport from windward to leeward sides creating a sediment depocenter towards the western end of each reef platform.

Table 1. Physical characteristics of sand cays in the Capricorn-Bunker Group.

\begin{tabular}{|l|l|l|l|l|l|l|l|l|}
\hline $\begin{array}{l}\text { Island/ } \\
\text { Reef }\end{array}$ & $\begin{array}{l}\text { Island } \\
\text { length, } \\
1(\mathrm{~m})\end{array}$ & $\begin{array}{l}\text { Island } \\
\text { width. } \\
\mathrm{w}(\mathrm{m})\end{array}$ & $\begin{array}{l}1 / \mathrm{w} \\
\text { ratio }\end{array}$ & Island shape & $\begin{array}{l}\text { Orient } \\
\text { ation } \\
\left({ }^{0}\right)\end{array}$ & $\begin{array}{l}\text { Island } \\
\text { Area } \\
(\mathrm{ha})\end{array}$ & $\begin{array}{l}\text { Reef } \\
\text { area } \\
\left(\mathrm{km}^{2}\right)\end{array}$ & $\begin{array}{l}\text { Reef } \\
\text { shape }\end{array}$ \\
\hline W. Hoskyn & 587 & 122 & 4.8 & Linear & 49 & 12.5 & 2.4 & Ovate \\
\hline Masthead & 145 & 349 & 4.2 & Lanceolate & 98 & 50 & 6.9 & Elliptic \\
\hline Erskine & 226 & 80 & 2.8 & Elliptic & 69 & 4.7 & 0.9 & Ovate \\
\hline Heron & 779 & 232 & 3.3 & Cuneate & 103 & 29 & 26.1 & Obovate \\
\hline Wreck & 653 & 105 & 6.2 & Lanceolate & 68 & 14 & 4.7 & Obovate \\
\hline North West & 1690 & 810 & 2.1 & Elliptic & 67 & 150 & 29.4 & Cuneate \\
\hline Tryon & 661 & 164 & 4.0 & Linear & 63 & 21 & 1.7 & Obovate \\
\hline
\end{tabular}

In addition to their similar location on the reef platform and comparable sediment size the sand cays all have low elevation (3.0 to $4.5 \mathrm{~m}$ above MSL) and the presence of outcrops of beachrock (especially on their northern and southern shores). Moreover, all of the sand cays have an elongate plan shape with the long axis from 2.1 to 6.2 times the maximum island width. Typically the long axis is oriented in an east to west direction, between $49-103^{0}$ (Table 1).

Heron Island is the only sand cay in the Capricornia Group that has permanent settlement, the other five sand cays being uninhabited and covered in dense vegetation. The island is located towards the western end of a large $\left(>26 \mathrm{~km}^{2}\right)$ lagoon reef platform (Figure 2). It is also the site of a tourist resort and a research station operated by the University of Queensland (Figure 3). A shoreline-monitoring program on Heron Island commenced in 1972 after major damage was caused by TC Emily (2 April, 1972). Since that time there have been several studies discussing the short- and long-term changes in the shape of the cay (e.g., Flood, 1974, 1986, 1988; Gourlay and Flood, 1981). Monitoring the shoreline position on Heron Island over four decades to 2012 has successfully differentiated natural perturbations from humaninduced changes to the perimeter of the cay. Natural cyclic changes have been related to variations in the direction of wind-induced waves to recurrent ENSO events (Flood, 1986). Human induced changes include: building rock retaining walls; beach replenishment work; and harbour dredging, all of which have impacted the foreshore and adjacent reef flat (Gourlay and Flood, 1981). The monitoring programme has demonstrated relative stability over 40 years of the shoreline on the eastern end on the cay, whereas the western end has recorded considerable instability. This area is unlikely to regain its earlier 'stable' plan form as described by Steers (1937) due to a variety of engineering works along the NW corner of the cay. Heron Island's anthropogenically-affected shoreline dynamics have produced a more cuneate or 'rectangular' cay shape that is different from the uninhabited sand cays in the Capricorn-Bunker Group (Table 1).

\section{HISTORICAL ACCOUNT}

In 1945, the reef rim adjacent to the western end of Heron Island was breached using explosives to allow small boat access to the island during low tide. This produced a change in water flow around the cay and resulted in erosion of the NE corner of the cay and deposition from the NW to the SW. Subsequently a retaining wall was constructed along the eroding section of the beach. In 1966, a boat harbour was dredged in the position of the channel. However, operations were halted by TC Dinah in early 1967. The harbour walls were flattened allowing ebb and flood tidal currents to be channelled through the breaches in several places. Increased water flow produced further erosion of the western 
beaches. Erosion continued unchecked during the cyclone season of 1971 and 1972 and the harbour became infilled with sediment. It was re-dredged in late 1972 and the dredge-spoil placed on the NW

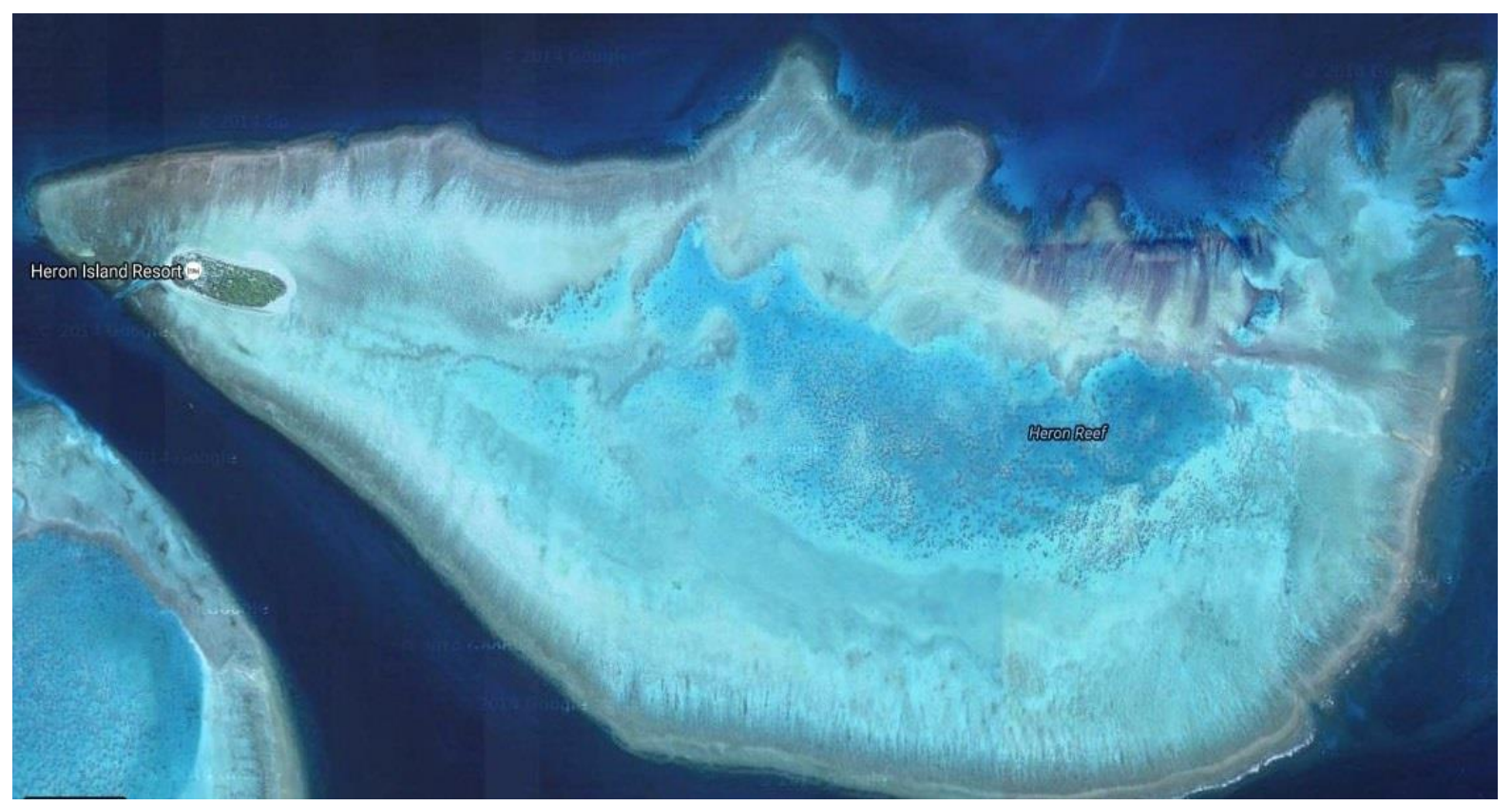

Figure 2. Google Earth Image (2006) of Heron Reef showing the position of Heron Island on the western end of the reef. Heron reef is $\sim 9 \mathrm{~km}$ long in an E-W direction, and $\sim 5 \mathrm{~km}$ wide N-S.

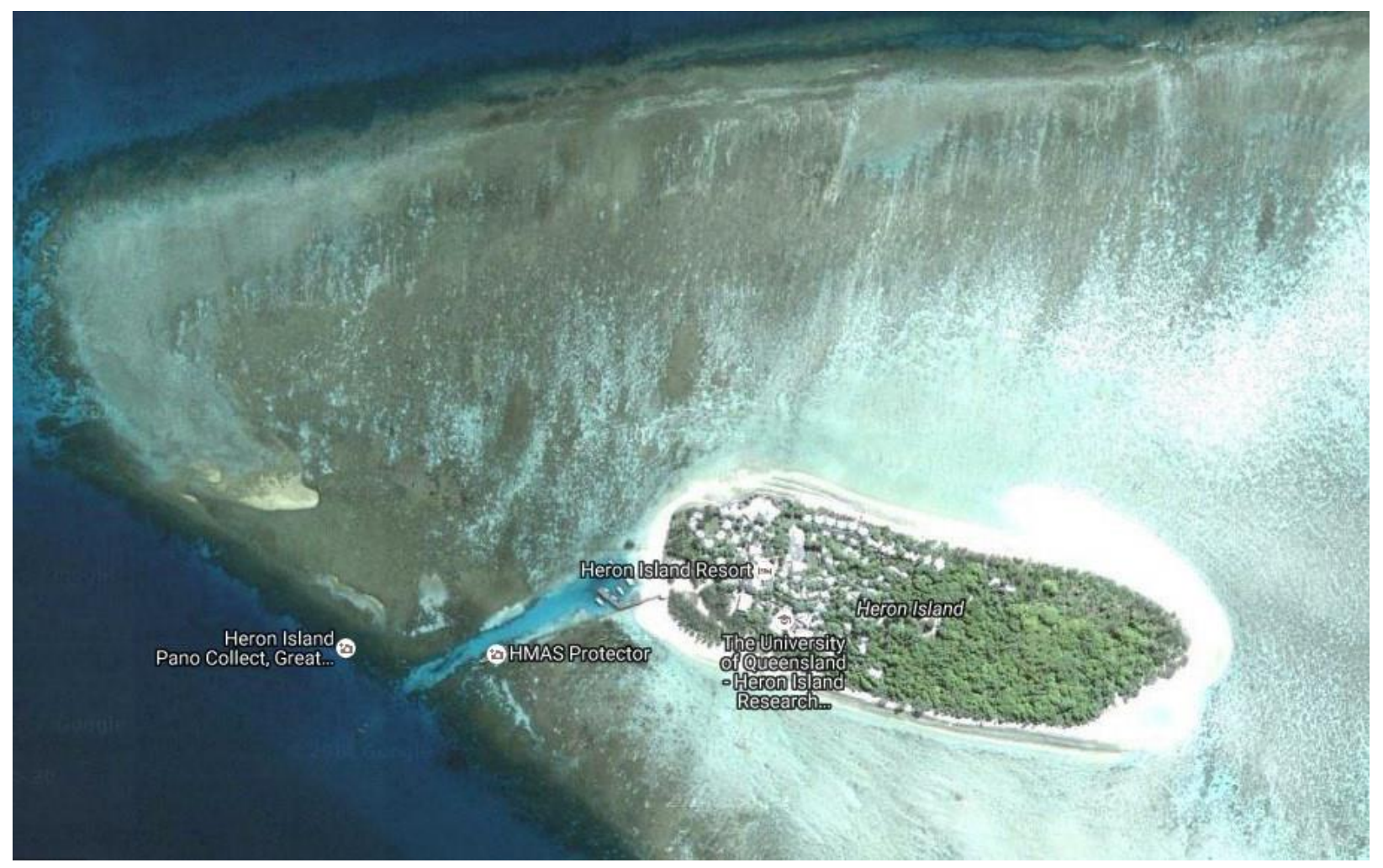

Figure 4. Google Earth Image of Heron Island, 2006; cay is about $800 \mathrm{~m}$ long and $230 \mathrm{~m}$ wide. The long axis of the view is orientated approximately East (RHS) to West (LHS). 
corner of the cay. Over the next nine years, that sediment moved back into the harbour. The harbour was re-dredged in late 1980-early 1981. That dredge spoil was placed on the SW corner of the island. Boat harbour enlargement works and dredging was undertaken in late 1987 and again in early 1988 (Gourlay and Jell, 1993). A timber jetty was constructed in 1988. The walls of the harbour were engineered 'properly' for the first time in 1993-1994 (Berkelmans et al., 1997) and were constructed to a height of $0.95 \mathrm{~m}$ above mean low water spring tide level. Unfortunately, the levels used for the harbour walls did not make adequate allowance for the subtle height difference between the slightly lower reef rim south of the boat harbour compared to that in the north which has resulted in the channelling of low water tidal current flow around the western end of the cay and through the harbour itself. Further construction of the walls would be required to negate this effect.

\section{FIELD METHODS}

A series of beach widths was measured from fixed survey points to the toe of the beach slope/reef flat interface at $\sim 30$ locations around Heron Island (Figure 4). These measurements, covering the period 1972-2012, when combined with published articles (Flood, 1974, 1986; Gourlay and Jell, 1993) and sequential vertical aerial photographs, provide an extensive database that enables seasonal, short and long-term trends in cay shape to be analysed. A similar method was used on three other sand cays in the Capricorn-Bunker Group, namely Erskine, Masthead and Tryon islands, details of which are described in Flood (1988).

On Heron Island the survey points consist of two sets, one described by Flood (1986); the other referring to the 'turtle observation sites' which are $10 \mathrm{~cm}$ diameter wooden posts at approximately $25 \mathrm{~m}$ intervals circumscribing the cay perimeter. In addition to the cross-beach transects planimetric surveys were undertaken in 1999 to measure the perimeter of the cay at low water along the line of the toe of the beach and the reef flat. This measurement was used to compare the perimeter obtained from the field survey sketch of the cay made by Kemp in 1936 (Steers, 1937) and the measurements obtained from the 1978 and 1982 vertical aerial photographs and a Google Earth image dated 4 July 2016.

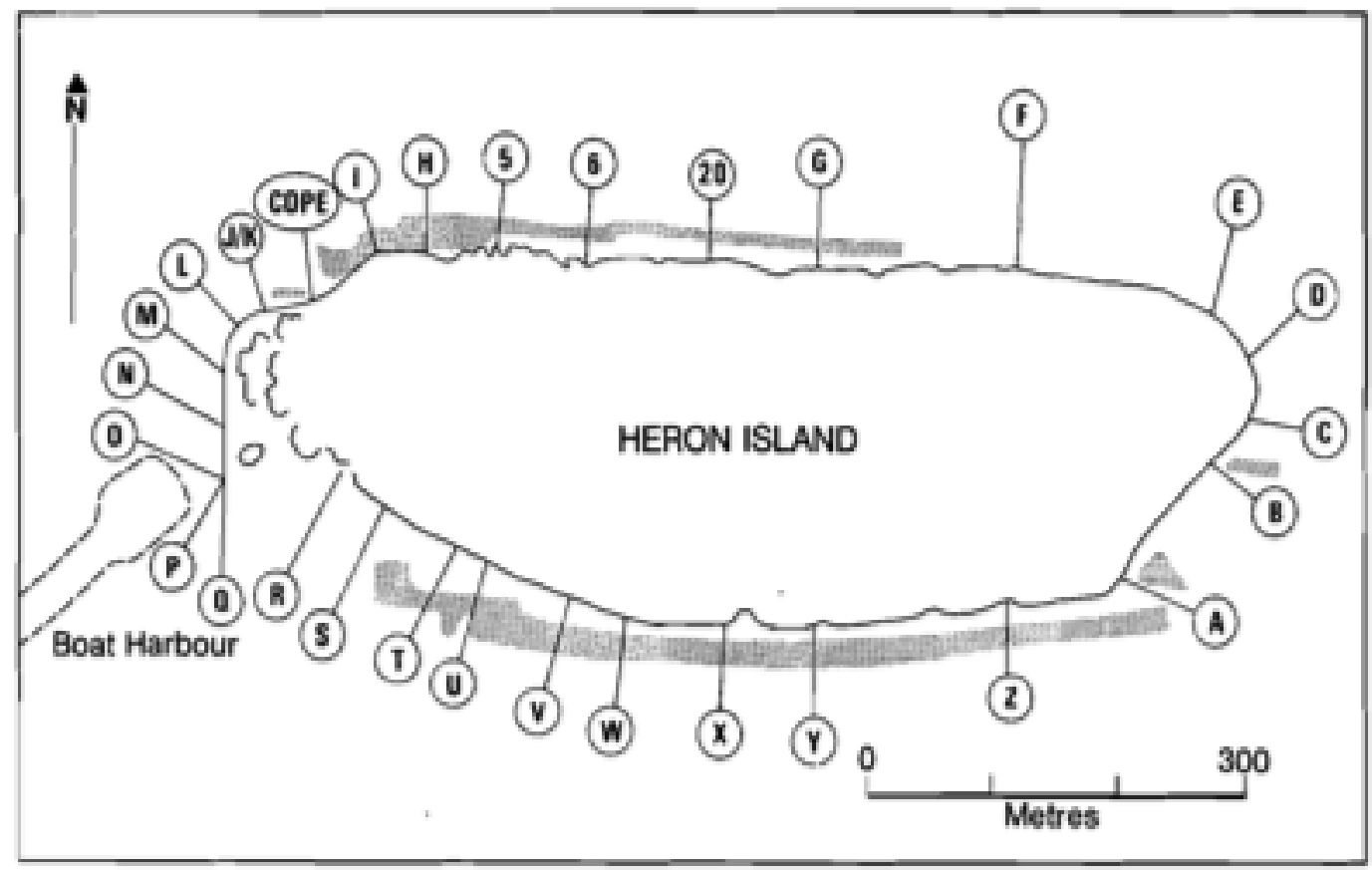

Figure 4. Location of beach survey monitoring points around Heron Island (after Flood, 1988). 


\section{RESULTS}

Distance measurements from the fixed survey markers to the base of the beach at low water were recorded on 13 occasions between 1972 and 1986 (see Flood, 1988) and 9 times since then not all of which include the 22 data points. The net changes between 1972 and 1986 and 1972 and 2016 are summarized in Table 2. Note that the cryptic comments in Table 2 do not do justice to the range of processes and changes that have occurred over the last few decades, but they do identify some critical events.

Table 2. Net change at monitoring sites over first 14 years and 44 years at Heron Island, 1972-2016.

\begin{tabular}{|c|c|c|c|}
\hline Site & $\begin{array}{c}\text { Change } \\
(\mathrm{m}) \\
1972-1986\end{array}$ & $\begin{array}{c}\text { Change } \\
\text { (m) } \\
1972- \\
2016\end{array}$ & Comment \\
\hline A & +4 & -12 & Initial accretion on eastern shore; later erosion from TC \\
\hline $\mathrm{B}$ & +13 & -13 & Initial accretion on eastern shore; later erosion from TC \\
\hline $\mathrm{C}$ & +4 & +14 & Initial accretion and later build-up of NE foreland spit \\
\hline $\mathrm{D}$ & -10 & +5 & Early erosion later build-up of NE foreland spit (Fig 3) \\
\hline E & -1 & +14 & Early erosion later extension of NE foreland to W (Fig 3) \\
\hline $\mathrm{F}$ & -3 & +10 & Early erosion later extension of NE foreland to W (Fig 3) \\
\hline $\mathrm{G}$ & -3 & -8 & Continuous minor erosion down-drift of NE foreland \\
\hline 20 & +1 & -2 & Minor change along center of northern shore \\
\hline 6 & 0 & -6 & Increase in erosion from longshore sand transport to W \\
\hline 5 & -1 & -5 & Increase in erosion from longshore sand transport to $\mathrm{W}$ \\
\hline $\mathrm{H}$ & -2 & -18 & Increase in erosion from longshore sand transport to $\mathrm{W}$ \\
\hline I & 0 & -8 & Erosion of dredge spoil from $1980-85$ no recovery \\
\hline Cope & -1 & -12 & Erosion of dredge spoil from $1980-85$ no recovery \\
\hline $\mathrm{J} / \mathrm{K}$ & 0 & -20 & Erosion of dredge spoil from $1980-85$ no recovery \\
\hline $\mathrm{L}$ & -16 & -18 & Early erosion from seawall later erosion of dredge spoil \\
\hline M & -16 & -12 & Early erosion from seawall later erosion of dredge spoil \\
\hline $\mathrm{N}$ & -13 & -11 & Early erosion from seawall later erosion of dredge spoil \\
\hline $\mathrm{O}$ & -46 & -10 & Early erosion from seawall later erosion of dredge spoil \\
\hline $\mathrm{P}$ & -17 & +54 & Early erosion from seawall, dredge spoil added $1987 / 88$ \\
\hline Q & -7 & +48 & Early erosion from seawall, dredge spoil added 1987/88 \\
\hline $\mathrm{R}$ & +4 & +35 & Initial accretion node from $\mathrm{W}$ erosion, dredge spoil added \\
\hline $\mathrm{S}$ & +23 & +30 & Initial accretion node from $\mathrm{W}$ erosion, dredge spoil added \\
\hline $\mathrm{T}$ & -3 & +24 & Initial minor change later accretion from $\mathrm{E}$ and $\mathrm{W}$ \\
\hline $\mathrm{U}$ & +8 & +21 & Long-term down-drift sink for longshore transport from E \\
\hline $\mathrm{V}$ & -1 & +12 & Minor variations in erosion/accretion along S shore \\
\hline $\mathrm{X}$ & -3 & +3 & Minor variations in erosion/accretion along S shore \\
\hline $\mathrm{Y}$ & -1 & +2 & Minor variations in erosion/accretion along S shore \\
\hline Z & +4 & +4 & Long-term minor accretion from eroding E shore of cay \\
\hline
\end{tabular}


The early findings have already been published and discussed in general terms in relation to both ENSO events and longer-term shifts in the dominant wind and wave directions (Flood, 1986, 1988). The results do show that the eastern end of Heron cay, that formerly trapped sediment from the extensive reef flat to the east, has subsequently been in an erosional state resulting initially from TC Emily. The sediment products from this shore erosion were transported north to form a large subtidal foreland spit on the NE shore of the cay. Excess sediment from the foreland has tracked to the west and by 2016 occupied about one-quarter of the northern shore of Heron Island. Downdrift of this promontory, which is clearly evident on Figure 3, longshore transport to the west has resulted in erosion of the upper beach and exposure of a series of lines of beachrock. These outcrops indicate the former seaward extent of the northern shore and its subsequent erosion. Beachrock is also exposed all along the southern shore and comprises a single outcrop that is continuous from the former spoil dump in the west to the eastern end of the cay.

Variations in the exposure of beachrock and its cover by beach sand results in frequent shifts in beach width and the measurements from survey markers to the toe of beach. This is suggested by the pattern of shore changes summarized in Table 2 and illustrated in Figure 5. Nevertheless these changes along the northern and southern shores of the cay have been dwarfed by those at the western end of Heron Island that have resulted from the impacts of seawall construction and the dumping of spoil from harbour dredging and its subsequent erosion as shown in Figure 6.

In addition to the cross-shore data on Heron Island, results from an analysis of plan-form changes over time can be made, thanks to the detailed field surveys of the islands in the Capricorn-Bunker Group in 1936 and maps produced by Steers (1937). For example, measurements of the perimeter of Heron Island have shown little variation over the last few decades, with Steers (1937) reporting a perimeter of $1800 \mathrm{~m}$ and calculations from 1978 and 1982 vertical air photograph of $1860 \mathrm{~m}$ and $1840 \mathrm{~m}$ respectively. The cay's perimeter measured in the field on 10 February 1999 was $1915 \mathrm{~m}$, the increase in length resulting from the addition of material dredged from the boat harbour in $1987\left(\sim 15,000 \mathrm{~m}^{3}\right)$. That this material has been reworked and redistributed since then is suggested by the perimeter measure of $1790 \mathrm{~m}$ based on Google Earth image dated 4 July 2016.

Whilst the length of the perimeter and therefore the area of Heron cay has shown only minor variation, there have also been changes in the cay's plan shape. A 1973 vertical image of Heron Island included as Plate 1 in Flood (1977) together with a series of later images in Plate 10 clearly show the cay has an ovate form, though the recent 2016 satellite images reveal a more wedge-shaped or cuneate outline with the broadest base of the wedge located at the western end of the cay. Such a shape change likely results from the presence of the ridged sea- and harbour- walls and placement of dredge spoil in this area. Together these limit the potential plan and profile adjustments of the island shore to natural variations in sediment transport processes. Such a limitation is not evident on any of the other sand cays in the Group.

Comparison of the long axis alignment of the sandy cays of the Capricorn-Bunker Group based on the map surveys in 1936 and measurements from 2016 satellite imagery (see orientation column in Table 1) shows that the islands are now aligned $2-13^{\circ}$ north of their former orientation with Erskine $6^{\circ}$, Heron $10^{\circ}$, Hoskyn $7^{\circ}$, Masthead $3^{\circ}$, North West $13^{\circ}$, Tryon $6^{\circ}$ and Wreck $2^{\circ}$. The consistency of this directional change suggests a regional mechanism at work like the change in wind resultant energy vectors from SSE to ESE between 1962 and 1980 described by Flood (1986) for Erskine Island. In that instance the orientation of Erskine cay in 1964 reflected the predominance of the SSE winds, whilst that in 1980 reflected the change in the predominant winds coming from the ESE.

Medium-term directional variations in regional winds and their accompanying seas can be expected to modify longshore drift directions around a cay as well as the location of the nodal point of sedimentation both of which are also influenced by the size, shape and character of the reef platform. In a subsequent study Flood (1988) noted that the resultant direction of island migration was not uniform and that during the period 1976-1984 Erskine island moved to the SE, Tryon to the NW, Masthead to the ESE and Heron to the SW and suggests that wave refraction around each reef platform 'has a unique signature affecting the erosion/accretion pattern on the cay' (Flood, 1988, p.220). 


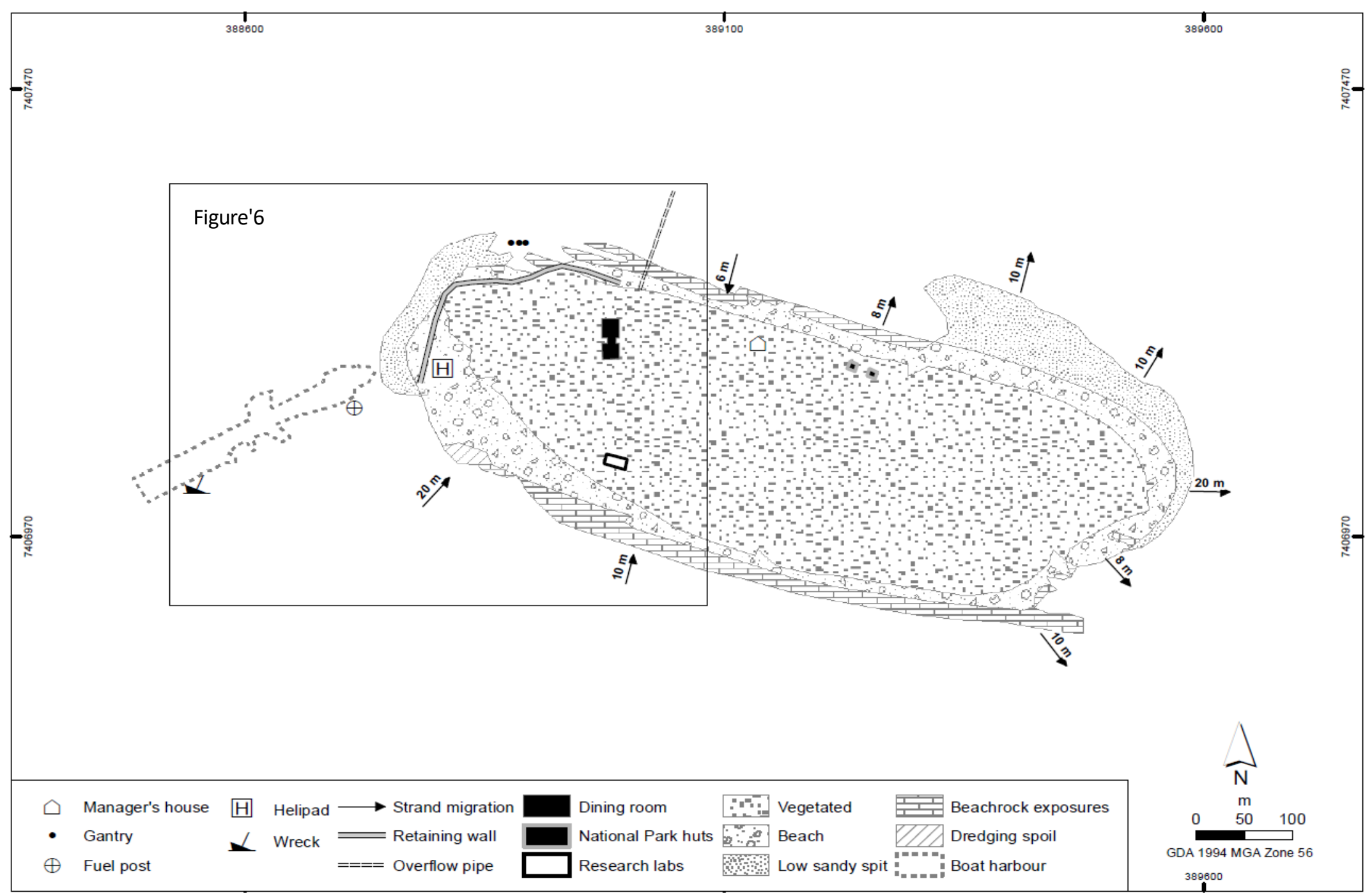

Figure 5. Map of Heron Island as at June 1980 showing general direction and amount of shoreline retreat and advance over four decades to 2012 . For details of changes in inset see Figure 6. 


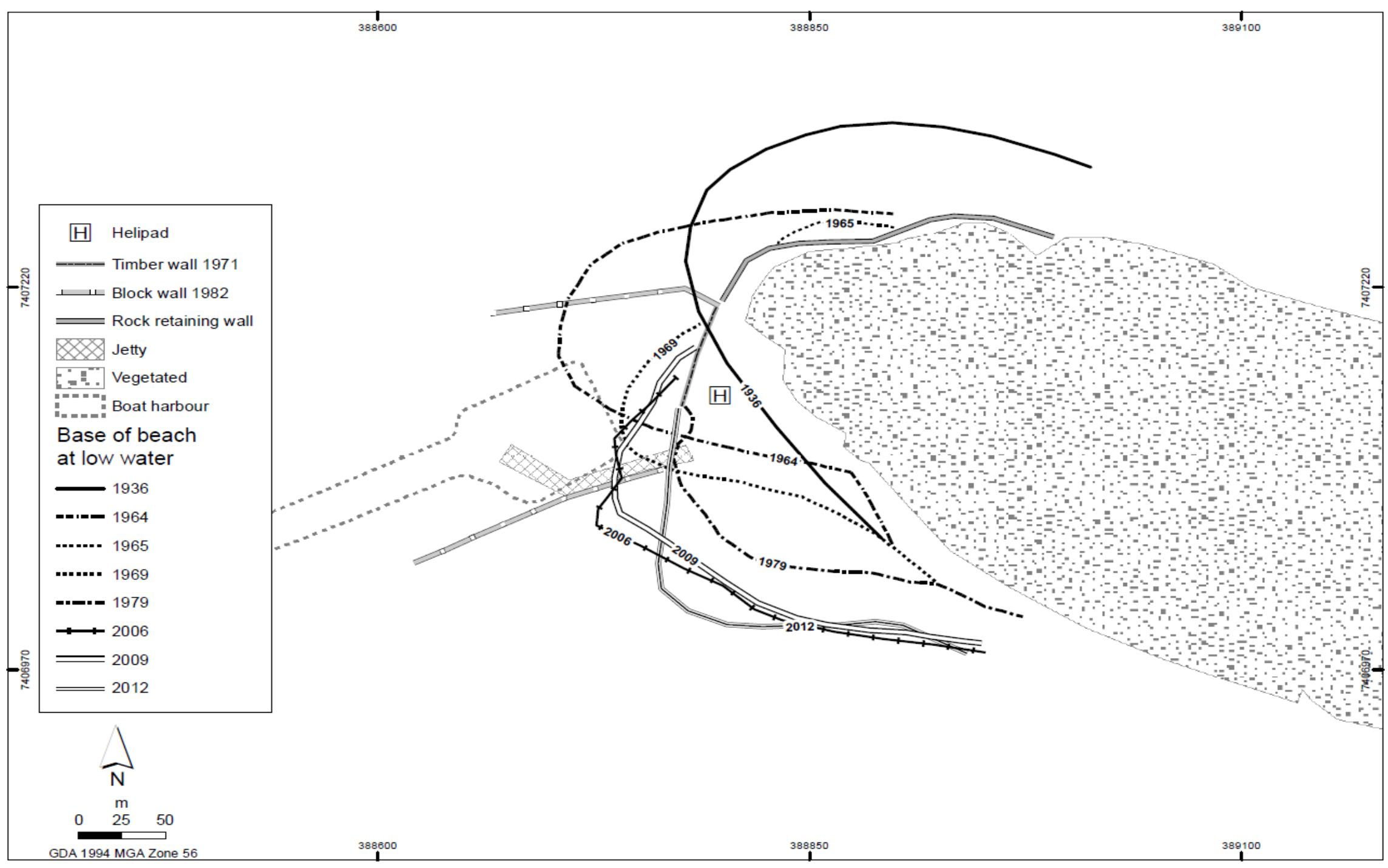

Figure 6. Location of seawalls, harbour and shoreline positions at the western end of Heron Island from 1936-2012. 


\section{DISCUSSION AND CONCLUSIONS}

The study of erosion and reorientation of coral cays is a topical item of interest in understanding the vulnerability of reef islands to climate change and sea level rise (Houser et al., 2014; McLean and Kench, 2015). In many instances the prediction is that they will disappear by the end of this century. The present analysis of Heron Island provides a cautionary lesson of not using general results without understanding the individual context of the study site. At Heron Island the most common sediment transport process is longshore drift. However, cyclonic events if they occur at high tide can have catastrophic impacts on beach erosion. On Heron Island beachrock outcrops prevent sediment from being added to the northern and southern beaches from their reef flats such that the only fresh sediment being added to the cay is material that reaches the eastern beach from the adjacent and extensive shallow lagoon. Along the western sector of the island additional sediment from harbour dredging, placed on the southwestern beach, has been of importance in increasing the volume of sediment available for longshore drift.

During the 40-year period of observation (1972-2012), the north eastern corner of the cay has accreted $\sim 10-15 \mathrm{~m}$, much of the southern beach has remained stable, whilst the northern beach has experienced erosion of up to $\sim 20 \mathrm{~m}$ along its western half. No sediment has accreted along the line of the reflective rock revetment wall in the northwest, whilst in the southwest the shoreline has accreted some $30-50 \mathrm{~m}$. This accretion has been aided by the placement of spoil from the harbour dredging of 1987 although there has been ongoing erosion of the spoil heap since then.

The ongoing shoreline monitoring program described here has demonstrated the marked contrasts between the condition of the eastern and western sections of Heron Island. On the one hand the morphodynamics of the eastern shore reflects the subtle impacts of natural processes while at the western end, where there have been extensive modifications associated with engineering works, the shoreline reflects these human impacts. In the longer-term it is likely that the western shore will continue to adjust until new equilibrium condition is reached or new shore protection and harbour works constructed. In either case it is unlikely Heron Island will regain its former 1936 shape as mapped by Kemp and described by Steers (1938). More likely, in the absence of fresh construction or harbour dredging, the new 'equilibrium' shape would include a SW orientated sand spit or foreland. Such a feature will be in marked contrast to the shape of other cays in the Capricorn-Bunker Group. Therefore, the changed dynamics of shoreline behaviour at Heron Island resulting from major engineering works over the last few decades dictate that this island should not be used as a model in shoreline behaviour studies considering the impact of climate change, sea level rise and other natural dynamic processes.

\section{ACKNOWLEDGEMENTS AND PERSONAL NOTE}

During the Second International Coral Reef Symposium on the Great Barrier Reef in 1973 I had the pleasure of meeting David Stoddart who encouraged me to continue to investigate the changing shape of coral cays on the Great Barrier Reef. I later formed a life-long friendship with David during his leadership of the 1973 Royal Society of London and Universities of Queensland Northern Great Barrier Reef Expedition of which I was a member. It was his continuing encouragement that lead me to contribute an article on Coral Cays of the Capricorn and Bunker Groups to the Atoll Research Bulletin (Flood, 1977) and to continue research on shoreline changes on coral cays.

This research was supported by the Australian Research Grants Committee, the Great Barrier Reef Marine Park Authority, the University of New England small ARC Grants, and the Royal Australian Air Force. I also gratefully acknowledge the use of facilities at the Heron Island Research Station and the Heron Island Resort. 


\section{REFERENCES}

Berkelmans, R., Oliver, J., Byron, G., and Olds, J. 1977. Impact assessment of Heron Island bund wall on coral communities. Reef Research, 7 (1), 6-9.

Flood, P. G. 1974. Sand movements on Heron Island, a vegetated sand cay, Great Barrier Reef Province, Australia. Proceedings Second International Coral Reef Symposium, 2, 387-394.

Flood, P. G. 1977. Coral cays of the Capricorn and Bunker Groups, Great Barrier Reef Province, Australia. Atoll Research Bulletin, 195, 1-7.

Flood, P. G., 1986. Sensitivity of coral cays to climatic variations, southern Great Barrier Reef, Australia. Coral Reefs 5, 13-18.

Flood, P. G. 1988. Shoreline changes on coral cays, Capricornia Section, Great Barrier Reef Marine Park, Australia. Proceedings Sixth International Coral Reef Symposium, Australia, 2, 219-224.

Gourlay, M. R. 2011. Infrastructure and Reef Islands. In: Encyclopedia of Modern Coral Reefs, Hopley, D. (Ed) Springer 601-607.

Gourlay, M. R. and Flood, P.G. 1981. Impact of Coastal Engineering works upon a Coral Cay: Heron Island. Conference on Coastal Engineering, Townsville, 159-163.

Gourlay, M. R. and Jell, J.S. 1993. Heron Island Spoil Dump. Great Barrier Reef Marine Park Authority Research Publication No. 25.

Houser, C., D'Ambrosio, T., Bouchard, C., Heyman, W., Darbonne, K., and Kuykendall, S. 2014. Erosion and reorientation of the Sapodilla Cays, Mesoamerican Reef Belize from 1960 to 2012. Physical Geography, 35 (4), 335-354.

Maxwell, W. G. H. Day, R. W. and Fleming, P. J. 1961. Carbonate sedimentation on Heron Island reef, Great Barrier Reef. Journal of Sedimentary Petrology, 31, 215-230.

McLean, R. and Kench, P. 2015. Destruction or persistence of coral atoll islands in the face of $20^{\text {th }}$ and $21^{\text {st }}$ century sea-level rise? WIREs Climate Change 2015. Do: $10.1002 / \mathrm{wcc} .350$

Steers, J. A. 1937. Detailed notes on the islands surveyed and examined by the geographical expedition to the Great Barrier Reef in 1936. Reports to the Great Barrier Reef Committee, 4, 51-96.

Stoddart, D. R. McLean, R. F. Scoffin, T. P. and Gibbs, P. E. 1978. Forty-five years of change on low wooded islands, Great Barrier Reef. Philosophical Transactions of the Royal Society of London Series B, 284, 63-80. 



\title{
HOLOCENE SEA LEVEL ON THE GREAT BARRIER REEF: REFLECTIONS ON FOUR DECADES OF DEBATE AND THE LEGACY OF THE 1973 EXPEDITION TO THE NORTHERN GREAT BARRIER REEF
}

\author{
SCOTT SMITHERS ${ }^{1}$, DAVID HOPLEY ${ }^{1}$ and ROGER MCLEAN ${ }^{2}$
}

\begin{abstract}
The main aim of the Royal Society and Universities of Queensland expedition to the northern Great Barrier Reef in 1973 was to elucidate the recent history of the reefs, especially in response to Holocene sea-level change. The expedition comprised three separate phases, lasted four months and was led by David Stoddart. At the time there was strong debate about the pattern of mid-late Holocene sea level both globally and in Australia and especially over whether the last phase of the post-glacial transgression showed a decelerating trend, or stable pattern, or whether there had been a highstand above present sea level. Members of the 1973 expedition included protagonists who supported a Holocene high as well as those who held the view that sea level had not reached above its present position in the past few millennia. Here we reflect on the advances in understanding Holocene sea-level changes on the northern Great Barrier Reef as a result of the expedition and its report published in a series of papers in 1978. First, we identify four key contributions of the expedition: (1) a detailed assessment of several geomorphological and biological sea-level indicators and the water-levels to which they refer; (2) recognition that the upper surface of coral microatolls can provide a reliable and precise record of contemporary and palaeo-sea levels; (3) that surveys of microatoll elevation and ${ }^{14} \mathrm{C}$ determinations on several reefs in the northern GBR provided unequivocal evidence that present sea level was first achieved about 6000 years ago then shortly thereafter rose 1.0 to $1.3 \mathrm{~m}$ to a highstand that was possibly maintained to about $3000 \mathrm{yr}$ BP before falling to its modern level; and, (4) although the concept of hydro-isostacy was still in its infancy the geographic pattern of age/sea level results from the expedition demonstrated that apparent sea-level differences across the GBR could be explained by the isostatic contribution. Second, we review the many sea level studies on the Great Barrier Reef since publication of the expedition's report in 1978 distinguishing those that focus on the northern sector and then the central and southern sectors of the GBR. This assessment reveals that the general pattern of mid-late Holocene sealevel history established during the expedition has not changed significantly, although improved calibration of ${ }^{14} \mathrm{C}$ ages has modified the time-frame. It is also clear that there are substantial differences in the abundance and quality of Holocene sea-level data, indicator types and interpretations throughout the length and breadth of the GBR. Third, from this analysis we identify two contentious issues, one relating to the elevation, timing, duration and geographic extent of the Holocene highstand, and the other on whether the fall of sea-level from that high to its present position has been smooth or oscillating. Finally, we conclude by noting that these contentious issues were also present over four decades ago at the time of the 1973 expedition but are still to be resolved.
\end{abstract}

\section{INTRODUCTION}

The principal aim of the 1973 Royal Society and Universities of Queensland Expedition to the northern Great Barrier Reef (hereafter referred to as the 1973 NGBR expedition or the Stoddart

\footnotetext{
${ }^{1}$ College of Science and Engineering, James Cook University, Townsville 4810 Australia,

${ }^{2}$ School of Physical, Environmental and Mathematical Sciences, University of New South Wales Canberra at the Australian Defence Force Academy, Canberra 2610, Australia.
} 
expedition) was to 'elucidate the recent history of the reefs, especially in response to Holocene sea level change' (Stoddart, 1978, p.5). In seeking to address this aim, expedition scientists focused on three sets of inter-related problems dealing with reef and reef landform morphology, reef structure, and reef growth history, and were fully aware that all were 'impossible to consider... without being concerned with the effects of Pleistocene changes of sea level on the reefs' (Stoddart, 1978, p.11). However, despite consensus regarding the importance of sea-level history to understanding coral reef development and morphology on the Great Barrier Reef (GBR) and elsewhere, at the time of the 1973 expedition there was no consensus on the details of Holocene sea-level history either globally or in Australia. Rather, it was the subject of vigorous debate.

That debate was cryptically summarized by one group of protagonists prior to the 1973 NGBR expedition as follows:

"Basically three schools of thought exist on sea level changes during the last 5000 to 7000 years. The first believes that eustatic sea level rose from the glacial low levels to its present position 3000 to 5000 years ago, and has been relatively constant ever since; the second, that sea level crossed the zero line of our present sea level 5000 to 6000 years ago and has fluctuated above and below the zero line ever since; and the third, that eustatic sea level has gradually approached present datum and may still be continuing to rise" (Curray et al., 1970, p. 1865).

Each of the three schools had its favored Holocene sea level curve(s). The first and third group believed that sea level had never been above its present elevation in the past few thousand years. This view was based on evidence from both sides of the Atlantic Ocean (e.g. Jelgersma, 1961; Shepard, 1963). On the other hand, data from the Pacific indicated to Fairbridge (1961) and others (e.g. Schofield, 1970) that sea level first reached and then rose above present level around 6000 years ago and oscillated both above and below that position through to the present. Observations of elevated fossil corals from Funafuti were used to support early interpretations of a postglacial sea-level high (David and Sweet, 1904), along with emergent shoreline terraces located on both the east and west coasts of the Australian continent (Daly, 1920). However, the mid-late Holocene sea-level highstands depicted in Fairbridge's (1961) curve were largely supported by radiocarbon-dated emergent shorelines in Western Australia, whereas the evidence for sea level remaining below present throughout the Holocene in Shepard's (1963) curve, came mainly from the east coast of the USA, the Caribbean and the Netherlands.

In an effort to advance this debate the (US) National Science Foundation supported the 1967 CARMASEL expedition (Caroline-Marshall Islands Sea Level Investigation) that examined reported evidence of higher Holocene sea levels in the central Pacific. They investigated 33 islands scattered widely across the Caroline and Marshall Island groups and in their initial report they found no 'direct evidence of post-glacial high stands of sea level' (Shepard et al., 1967, p.542). Subsequent detailed contributions by members of the CARMARSEL expedition confirmed this view (e.g. Bloom, 1970; Curray, et al., 1970; Newell and Bloom, 1970). Their conclusions were later challenged in a number of papers that reported radiometrically dated emergent in situ reefs of Holocene age formed at higher sea level through the same region (Tracey and Ladd, 1974; Buddemeier et al., 1975; Schofield, 1977).

The polarity and strength of debate at the global scale was matched by dispute regarding the details of Holocene sea-level changes in Australia and on the GBR, particularly around the existence, amplitude, timing and geographical extent of any Holocene highstand. That dispute has been well covered by Hopley (1982) and McLean (1984) and most recently by Lewis et al. (2013, p. 125-127) and MurrayWallace and Woodroffe (2014, p. 330-334). Fairbridge's (1961) claim of higher Holocene sea levels received early support from Gill's (1961) investigations in Victoria, but were questioned by Hails (1965) who critically reviewed Australian sea-level evidence and concluded that postglacial sea level had been stable and never higher for approximately 5000 years. A spirited debate played out in the literature in the decade following, with strong views held both for (Hopley, 1971; Gill and Hopley, 1972) and against (Thom et al., 1969, 1972) a higher Holocene sea level. Much of the contention stemmed from difficulties 
in reconciling divergent sea-level histories from different localities (see Hopley, 1975, 1982 for discussion), and consequent judgements about the quality of evidence and interpretations supporting the opposing view (e.g. Thom et al., 1972; Belperio, 1979).

At the core of this debate was the belief that there was just one singularly-correct global (eustatic) sea-level curve, a notion now known to be deficient as it ignores a number of other potential influences including isostatic adjustments of the Earth's crust to redistributions of ice and water volumes since the last glacial maximum (Walcott, 1972; Nakada and Lambeck, 1989; Lambeck et al., 2010). This notion of hydro-isostacy was very much in its infancy prior to the 1973 NGBR expedition though the possibility of tectonic deformation and warping on the GBR was considered at the Second International Coral Reef Symposium held on the GBR immediately before the expedition (Hopley, 1974).

This then was the context of the 1973 expedition. Led by David Stoddart, the expedition brought together scientists from opposing sides of the sea-level debate who together carefully examined evidence of Holocene sea level preserved on reefs of the northern GBR with geomorphological investigations at 66 sites north of Cairns (Figure 1).

While initially not the focus, it later became clear that the expedition did resolve some of the 'ambiguities in the evidence for positive and negative sea-level changes in the northern Great Barrier Reef area' (Stoddart, 1978, p.12). In fact, the detailed research undertaken on this expedition yielded many significant contributions, some of which are summarized below. This paper reflects on the significance of the advances in understanding Holocene sea-level changes on the GBR (and more broadly) made directly during the Stoddart expedition, and those prompted by its results. Progress since the expedition is reviewed, and details that remain contentious are discussed. Finally, Stoddart (1978, p.12) recognized that understanding sea-level history, including very recent changes, is 'crucial to an interpretation of recent reef history'. We conclude by noting this linkage and argue how an awareness of the details of sea-level history - and the geographic differences in these details - are critical to understanding reef development and change. Such differences must be appreciated in contemporary management of the Great Barrier Reef.

\section{MAJOR CONTRIBUTIONS OF THE 1973 NGBR EXPEDITION TO UNDERSTANDING HOLOCENE SEA-LEVEL CHANGE}

By any measure the 1973 NGBR expedition contributed enormously to the resolution of the Holocene sea-level debate. The final three of the thirteen papers published as a discussion of expedition results in the Philosophical Transactions of the Royal Society London Series A, volume 291 were dedicated specifically to sea level and sea-level change. Many others in this volume, and the companion Series $B$ volume 284, also focused on, or discussed in detail, sea-level indicators, especially microatolls (see Scoffin and Stoddart, 1978), or incorporated evidence of sea-level changes in their interpretations (e.g. Stoddart et al., 1978a and 1978b; Scoffin et al., 1978). The significance of these contributions reflects the intellect and skills of the individual scientists involved with the expedition. However, it is hard not to agree with McLean's (1984, p.434) earlier reflection that the collaborative investigations by 'contrary Holocene sea-level historians' under the 'impartial' leadership of David Stoddart was a key factor in its success. Below we discuss four major contributions to Holocene sea-level investigations made by the 1973 NGBR expedition.

\section{Critical Audit of Sea-Level Indicator Precision and Reliability}

A key task and outcome of the expedition was the systematic review of the evidence used to reconstruct past sea levels, including recognition of the limitations of the data and the assumptions associated with its interpretation (Scoffin, 1977; Hopley, 1978; McLean et al., 1978). Consideration was given to a number of problems including:

- difficulties associated with reliably reducing survey elevations to a common tidal datum; 
- uncertainties involved in consistently relating features used as sea-level indicators to specific tidal stages at the time of formation at varied locations;

- the (mis)identification and (mis)interpretation of reef features and thus their significance as sealevel indicators;

- inaccurate and/or imprecise dating from sample contamination and inadequate or inappropriate pre-treatment; and,

- the possibility that phenomena such as tectonic movements and modified tidal and storm regimes may complicate interpretations.

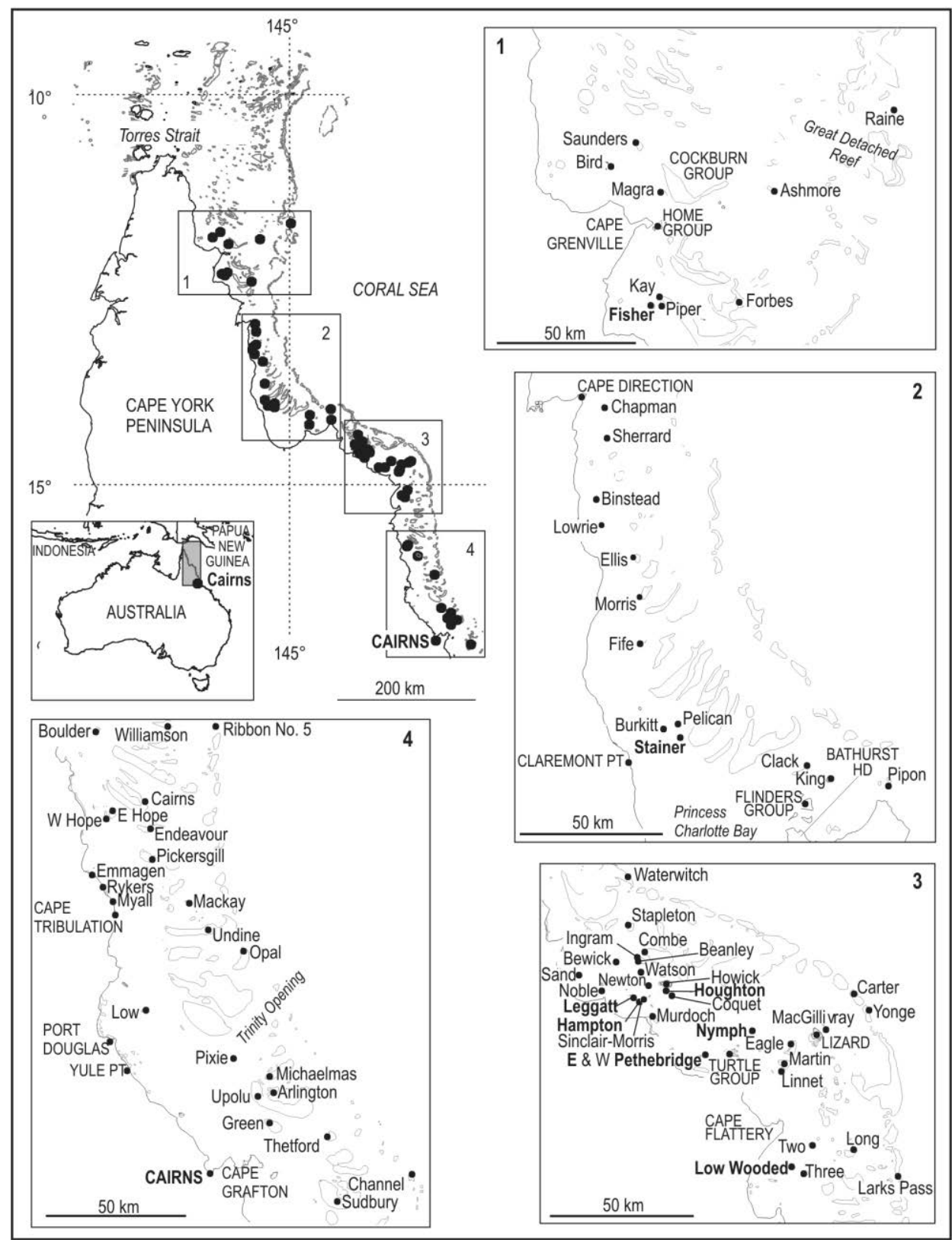

Figure 1. The northern Great Barrier Reef, north of Cairns. Locations visited by the Stoddart expedition are identified on the insets, with sites from which radiocarbon-dated sea-level evidence, mainly microatolls, were collected shown in bold text .See Table 1 for calibrated radiocarbon ages. 
To our knowledge, this was the first systematic critical audit of such an extensive and diverse collection of sea-level evidence by supporters of different sea-level histories working together in both the field and on the interpretations of results. Quantitative error terms were established for some of these 'problems' to guide the confidence with which the significance of derived sea-level data could be interpreted. For example, relative levels between features on the same traverse and between traverses on the same reef were regarded as accurate to within a few centimeters whilst between reefs a possible discrepancy of up to $0.5 \mathrm{~m}$ was recognized for elevations surveyed to the same tidal datum (attributable to difficulties defining 'still' water tide levels used as reference levels and uncertainties around the consonance of actual tides and those interpolated from predictions for often distant sites). Error terms ranging from \pm 70 to \pm 170 years were established for the radiocarbon ages (McLean et al., 1978).

Significantly, sea-level evidence from a diversity of sources was examined and stringently assessed, including: coral microatolls; biohermal reefs; mollusca (mainly Tridacna spp); beachrock; high and low terraces on sand cays; and shingle cays, ridges, ramparts and their cemented (platform) equivalents. At the time this was the most comprehensive array of biological and geological indicators used to develop a sea-level framework as well as the largest number of radiometric-dated samples (79) from the same reef province. The meticulous appraisal of the accuracy and precision of sea-level evidence pioneered on the 1973 expedition quantitatively defined the reliability of sea-level indicators used to construct conflicting sea-level histories, and pointed to those that were the most reliable.

\section{Demonstrated Importance of Coral Microatolls as Sea-Level Indicators}

Although coral microatolls were already known as possible sea-level indicators (e.g. Darwin, 1842; Abe, 1937), fossil microatolls had rarely been used with radiometric dates to document past sealevels prior to the expedition. One exception was reported immediately before the expedition at the Second International Coral Reef Symposium where Tracey and Ladd (1974, p. 542) described 'truncated microatolls of Heliopora up to $0.8 \mathrm{~m}$ diameter are exposed...0.15 to $1 \mathrm{~m}$ above mean low water' at Eniwetok atoll and dated at 3,290 \pm 145 and 2,255 $\pm 130 \mathrm{yr}$ BP. However, expedition results confirmed the pre-eminent status of coral microatolls as the most reliable and precise sea-level indicator found in reef top environments. This encouraged their use in sea-level studies thereafter (e.g. Hopley, 1975, 1982; Chappell, 1983; Chappell et al., 1982, 1983; Davies et al., 1985; Pirazzoli and Montaggioni, 1988; Pirazzoli et al., 1988; Smithers and Woodroffe, 2000; Woodroffe and McLean, 1990; Woodroffe et al., 1990, 2012; Kench et al., 2009). As Lewis et al. (2013, p. 117) recently acknowledged 'It was as part of this expedition that the significance of coral microatolls as accurate sea level recorders was realised'.

Coral microatolls still 'provide the clearest evidence of the elevation of sea level in the past' (Murray-Wallace and Woodroffe, 2014, p. 95). They continue to be recognized as a preferred proxy for reef flat age/sea level studies, as evidenced by the recent use of 55 dated microatolls in the Edgecumbe Bay area of the central GBR by Ryan et al. (2106a, 2016b, 2016c) and the analysis of 32 microatolls from multiple reefs in the Great Keppell area to construct a relative sea-level histories for these areas of the inner GBR (Leonard et al., 2016) (see Figure 2 for locations of sea-level evidence south of Cairns). Although these examples demonstrate coral microatolls are excellent sea-level indicators they must nonetheless be used and interpreted with care, a point underscored by Scoffin and Stoddart (1978) in the NGBR expedition report.

\section{Provided Unequivocal Evidence of a High Holocene Sea Level}

Assessment of carefully measured and interpreted sea-level evidence collected during the 1973 expedition unequivocally confirmed that sea level on the northern GBR was higher than present during the Holocene (McLean et al., 1978; Stoddart et al., 1978b). The heights and ages of fossil microatolls at four reefs (Houghton $5850 \pm 170$, Leggatt $5800 \pm 130$, Fisher $6310 \pm 90$, and Low Wooded $6080 \pm 90$ ) were considered 'firm evidence' that present sea level was first reached around 6000 years ago and that 


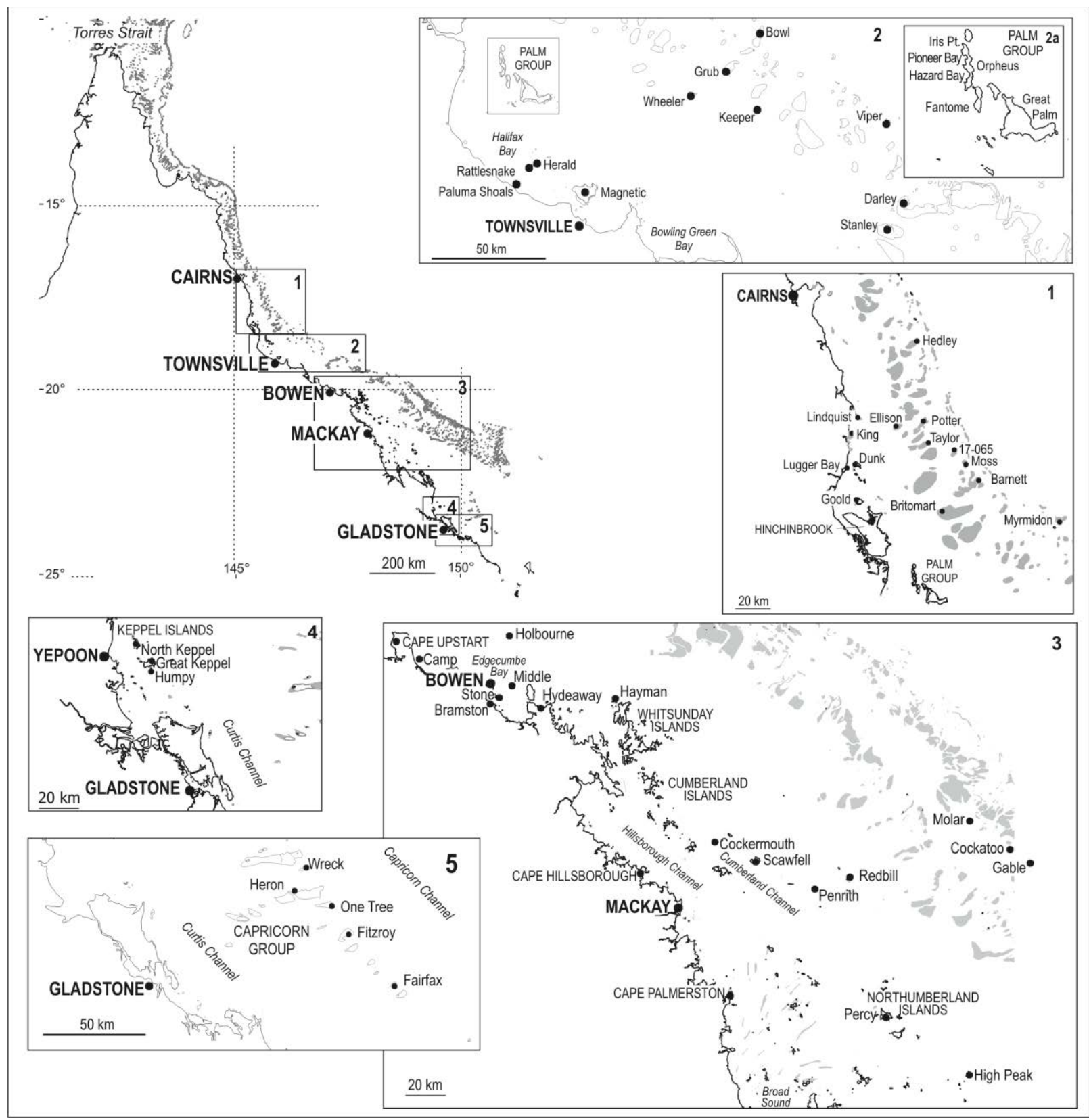

Figure 2. Map of Great Barrier Reef south of Cairns, showing the locations of sites listed in Table 2 from which dated reef surface materials (either microatolls or dated core material within $1.5 \mathrm{~m}$ of the reef flat surface) have been collected.

shortly after (by 5800 BP) it was marginally higher than present level (McLean et al., 1978 p.184). Fossil microatolls at two additional sites (Stainer and Hampton Reefs) indicated sea level remained above present at $4900 \mathrm{yr}$ BP. Comparison of the elevations of living microatolls and emergent fossil microatolls at Three Isles and Nymph Reefs showed that sea level was $>1 \mathrm{~m}$ above present around 3700 years ago, this evidence supporting the highest sea level ( $1.3 \mathrm{~m}$ above present) interpreted from expedition results (McLean et al., 1978). In fact, a number of reef-top features have ages clustering between 3200 and 3800 yr BP, indicating some evidence that in this period the highest Holocene sea level was reached. The evidence not only included the two extensive emergent fossil microatoll fields cited above, but also the 
high terrace of the larger cays (average age of 8 samples $\sim 3500 \mathrm{BP}$ ) as well as cemented shingle ramparts of the upper platform (average age of 8 samples 3546 B.P) (McLean et al., 1978 p. 185).

Fossil microatolls of younger age and lower elevation were viewed as evidence that sea level fell after this time, but the exact pattern of sea level fall to present was not well-defined. Ages established for higher and lower terraces on several sand cays and for several shingle cays and ramparts broadly supported the microatoll evidence suggesting sea level was falling from around $1 \mathrm{~m}$ above present by around 3000 years ago. However, the evidence from different sites is less consistent and the interpretations of deposit ages are more difficult than for the microatoll evidence (McLean et al., 1978).

In summary, evidence collected during the 1973 expedition confirmed that Holocene sea levels had risen approximately $1 \mathrm{~m}$ higher than present during the mid-Late Holocene. Age-elevation patterns for specific sea-level indicators were remarkably consistent between reefs, and sea level histories established from a diverse range of evidence reinforced rather than obscured a common pattern (McLean et al., 1978), increasing confidence in this conclusion. Importantly, Stoddart et al., (1978b) emphasized that expedition results should not be viewed as uncritically supporting Fairbridge's (1961) sea-level curve, as persistent ambiguities regarding the occurrence and nature of any oscillations were yet to be resolved. As noted by McLean et al., (1978, p.185), although the expedition results provided compelling evidence that sea level was above present for much of the past 6000 years, they were not "equally able to document levels lower than present' which also featured in Fairbridge's (1961) curve.

\section{Informed Hydro-Isostatic Models to Reconcile Varied Sea-Level Histories}

Prior to the 1973 NGBR expedition isostasy was emerging as a potential mechanism to explain the development of regionally different relative sea-level histories following Bloom's (1967) revival of Daly's (1925) hypothesis that loading and unloading of the Earth's crust as glacio-eustatic sea levels fluctuated could produce spatially variable patterns of sea floor deformation and coastal elevation adjustment (Walcott, 1972). The implications of this were not fully recognized during the expedition itself, but became more evident as results from the field surveys, laboratory work and radiometric age determinations were put together during the time between the end of the expedition and the publication of results in 1978, some 5 years later. Indeed, Hopley (1974, p. 559) had foreshadowed this development immediately prior to the 1973 expedition (in a paper presented at the Second International Coral Reef Symposium) when he noted that tectonic factors and differential movement both 'longitudinal to the coast' and 'normal to the coast may have taken place' on the GBR. As awareness increased of the isostatic sensitivity of continental shelves to variable water loadings generated by the Holocene transgression, the concept of hydro-isostasy was becoming recognized as a promising solution to the ongoing sea-level controversy both globally and on the GBR (Chappell, 1974).

The GBR is an important location for sea-level research as it is a 'far-field' site (Lambeck, 1993, p.18) not directly affected by variations in ice load, where a range of sea-level indicators can be found, and the Australian continent is relatively stable tectonically (Lewis et al., 2013). Without the confounding effects of neotectonics and ice offloading and onloading (glacio-isostasy), the GBR became recognized as an excellent location to investigate hydro-isostasy (Chappell, 1974; Hopley, 1974; Hopley, 1978; Thom and Chappell, 1975, 1978). Hydro-isostasy influences the relative sea-level history experienced at a location, with uplifted areas reaching a common sea level isobase earlier than down-warped areas (Chappell et al., 1982). Early researchers working on the northern GBR noted widespread evidence of emergence close to the mainland and its absence on the outer reef (e.g. Hedley, 1925; Spender, 1930; Fairbridge, 1950), a pattern Thom and Chappell (1975) reasoned was consistent with theoretical postglacial hydro-isostatic adjustment. However, the elevation and age of evidence of higher Holocene sea levels known at the time of the 1973 expedition varied markedly along the Queensland coast (Hopley, 1974, 1978), ranging from $1.2 \mathrm{~m}$ by 4100 years ago at Yule Point just north of Cairns (Bird, 1971) to as much as $4.9 \mathrm{~m}$ above present by 4600 years ago at Herald Island near Townsville (Hopley, 1974). Much farther south and beyond the GBR province, Thom et al. (1969) reported no evidence of higher Holocene sea levels in the Coolum area of the Maryborough Basin. 
The interpretation of sea-level data from the Stoddart expedition together with the global geophysical interest in the implications of water loading and unloading provided an appropriate context for two of the papers contained in the expedition's report that focused on hydro-isostasy and Holocene sea levels on the northern GBR (Hopley, 1978; Thom and Chappell, 1978). The importance of reliable palaeo-datum positions and accurate palaeo-sea levels needed to isolate relative sea level, tectonic, and isostatic contributions to sea-level changes was emphasized by Thom and Chappell (1978, p.189), who further noted 'the hydro-isostatic factor is generally neglected' a point that still appears to be true. Hopley (1978) stressed the influence of shelf structure and morphology on hydro-isostatic response, and noted that the northern GBR visited by the 1973 expedition was an excellent location to test hydro-isostatic models because reef-top sea-level indicators occur from the coast to shelf edge, allowing cross-shelf variations in uplift and subsidence to be established from reef surface ages and elevations and compared with hydro-isostatic model outputs. The abundance of living and fossil microatolls in this region, including those that were radiometrically-dated and surveyed to a consistent tidal datum during the 1973 NGBR expedition was also important, providing high-quality sea-level indicators to increase confidence in modelling outputs. Such confidence was critical because up to that time the highest interpreted sea levels on the central GBR were inferred from low-resolution indicators such as beachrock and thus whether the high elevations were real or an artefact required resolution (Hopley, 1978).

Attempts to reconcile disparate sea-level histories from different sites by locally 'tuning' for hydro-isostatic shelf flexure using early rheological models produced imperfect results, but confirmed that hydro-isostatic processes could explain some differences (Thom and Chappell, 1978). Most critically, the sea-level data and preliminary hydro-isostatic investigations produced by the 1973 expedition provided a solid base for improvements to rheological models and understandings of hydro-isostatic processes and their influence on relative sea-level histories, both in Australia (Thom and Chappell, 1975; Chappell, 1974, 1983; Chappell et al., 1982, 1983; Nakada and Lambeck, 1989; Lambeck and Nakada, 1990; Haworth et al., 2002) and globally (e.g. Clarke et al., 1978; Dickinson, 2003).

\section{SEA-LEVEL RESEARCH ON THE NORTHERN GREAT BARRIER REEF SINCE THE 1973 EXPEDITION}

Since publication of the 1973 expedition results there have been several reviews of sea-level history on the GBR (e.g. Hopley, 1982, 1983; Hopley and Thom, 1983; Chappell, 1987; Larcombe et al., 1995; Hopley et al., 2007; Lewis et al., 2008, 2013; Murray-Wallace and Woodroffe, 2014). This has involved adjusting the early chronologies due to recalibration of ${ }^{14} \mathrm{C}$ ages to account for secular variations in atmospheric ${ }^{14} \mathrm{C}$ and regional differences in the radiocarbon reservoir. Lewis et al. (2013) provide a plot of recalibrated data from northeast Queensland. In the 1970s and 1980s sea-level studies reported either uncorrected 'conventional' or 'environmentally corrected' ${ }^{14} \mathrm{C}$ ages (the latter typically meaning that $450 \pm 35$ years had been subtracted from the conventional ${ }^{14} \mathrm{C}$ age of marine samples to address the 'marine reservoir effect' - the age of ${ }^{14} \mathrm{C}$ at the time of inclusion (Gillespie and Polach, 1979)). These early studies generally report that the mid-Holocene high sea level was first reached between 6000 and 5500 years ago at about $1.0 \mathrm{~m}$ above present level (see Chappell, 1983; Hopley, 1983). More precise ${ }^{14} \mathrm{C}$ ages are now achievable due to improved calibration programs (Sloss et al., 2013).

These improved ${ }^{14} \mathrm{C}$ ages, (which can be calibrated to sidereal years) together with U-series ages (which do not require reservoir corrections), suggest that the mid- Holocene high sea level was reached

here earlier than initially proposed. Recalibration of early acquired ages from the northern GBR typically adds around 300-400 years to conventional ${ }^{14} \mathrm{C}$ ages, and another 450 years if original ages were 'environmentally corrected'. These adjustments shift the time of when the mid-Holocene equivalent of present sea level was first achieved on the northern GBR to around $6800 \mathrm{cal}$. yr BP (Lewis et al., 2013). Advances in surveying technology such as real-time kinematic GPS have also increased the precision with which sea-level indicator elevations can be measured and compared within and between reefs (e.g. Harris et al., 2015; Ryan et al., 2016a; 2016b, 2016c). However, despite these advances, difficulties still 
remain in reliably and meaningfully reducing survey heights referenced to a datum (that may be established for a distant site) to the tidal levels that the sea-level indicator responds to in the locally surveyed field setting.

Surprisingly, relatively few new sea-level data have been collected from the northern GBR since the 1973 expedition. The most extensive field investigation took place in 1980-81. Chappell (1983) and Chappell et al. (1983) visited and sampled sites on the northern GBR, including three previously reported on by the 1973 expedition (Nymph Island, West Hope, Low Wooded Island) as well as King Island, Flinders Island, Yule Point, and another eight sites between Cairns and Bowen. The sea-level history revealed by results from these locations confirmed that the highest sea level was reached between 6000 and 5500 years ago (uncalibrated ages) at about $1 \mathrm{~m}$ above present.

More recently, Kench et al. (2012) published several calibrated ${ }^{14} \mathrm{C}$ ages of microatolls from Bewick Island. These data suggest the highstand was reached by at least $6400 \mathrm{cal}$. yr BP with fossil microatolls (now covered by the vegetated sand cay) elevated between 1.18 and $1.55 \mathrm{~m}$ above their openwater living counterparts at the reef edge. An age of $5575 \mathrm{cal}$. yr BP for another fossil microatoll located on the emergent reef flat $\sim 0.75 \mathrm{~m}$ above modern microatolls indicate that sea level had begun to fall from the high by that time. These dates and elevations are consistent with the previous NGBR studies, but do not support the significantly earlier timing of between 8000-7000 cal. yr BP suggested from other parts of the GBR (Yu and Zhao, 2010; Woodroffe, 2009) (see later).

In contrast to inner shelf reefs, sea-level evidence from the mid-and outer-shelf reefs of the northern GBR is mainly limited to samples collected from within $1 \mathrm{~m}$ of the reef flat surface during reef coring programs, the results of which have been summarized in Hopley et al. (2007, table 3.3) and here in Table 1. No reliable evidence of emergence is reported from the mid-outer shelf reefs, but radiocarbon ages demonstrate that they did not lag far behind reefs nearer the mainland e.g. $\sim 5850 \mathrm{cal}$. yr BP from the reef flat surface at MacGillivray Reef (Rees et al., 2006).

\section{SEA-LEVEL RSEARCH ON THE CENTRAL AND SOUTHERN GREAT BARRIER REEF SINCE THE 1973 EXPEDITION}

Advances in understanding Holocene sea-level changes for the broader GBR have been similar to those established for the northern region discussed above. Lewis et al., (2013) summarize knowledge on mid-late Holocene sea-levels for the Queensland coast from Torres Strait to the NSW border based on literature to 2011. A key contribution of the Lewis et al., (2013) review was that it presented both recent U-series and calibrated ${ }^{14} \mathrm{C}$ ages for dated materials reported as unconventional or environmentally corrected ages in earlier publications. Generally, the recalibrated ages shift the timing of maximum Holocene sea level on the inner shelf several hundred years earlier than indicated by conventional ${ }^{14} \mathrm{C}$ dates to around 6800-5800 cal. yr BP. However, new data from a range of sea-level indicators from the inner shelf of the central GBR have been interpreted as evidence of the highstand being reached by at least 7000 cal. yr BP (Yu and Zhao, 2010), and possibly as early as 8000 years ago (Woodroffe, 2009).

Although broad consensus now exists that a highstand of around 1.0 to $1.5 \mathrm{~m}$ above present occurred along most of the inner central GBR, debate continues regarding the elevation and timing from place to place. Earlier estimates of a high 2-3 m above present on the central GBR based on beachrock data (e.g. Hopley, 1980, 1983) have generally been discounted in favor of a lower maximum provided by microatolls (e.g. Chappell et al., 1982, 1983; Hopley et al., 2007), although Woodroffe (2009) proposed a highstand $\sim 2.8 \mathrm{~m}$ above present around 5000 cal. years ago based on foraminiferal transfer function analyses. 
Table 1. Radiometric dates from the northern Great Barrier Reef within $1.5 \mathrm{~m}$ of reef surface (modified from Hopley et al., 2007)

\begin{tabular}{|c|c|c|c|c|c|c|c|c|c|}
\hline Location & $\begin{array}{c}\text { Lat. } \\
\mathrm{S} \\
\end{array}$ & $\begin{array}{c}\text { Long. } \\
\text { E }\end{array}$ & $\begin{array}{c}\text { Depth } \\
\text { Below } \\
\text { (MLWS) } \\
a \\
\end{array}$ & $\begin{array}{c}\text { Material } \\
b\end{array}$ & $\begin{array}{c}\text { Age } \pm \\
\text { error (yr) } \\
\end{array}$ & $\begin{array}{c}\text { Laboratory } \\
\text { code }\end{array}$ & $\begin{array}{c}\text { Calibrated age } \\
\text { Median probability } \\
(2 \sigma \text { range }) \\
\end{array}$ & $\begin{array}{l}\text { (I) Inner } \\
\text { (M) Mid } \\
\text { (O) Outer } \\
\text { Reef } \\
\end{array}$ & Ref \\
\hline Raine Is. & $11^{\circ} 36^{\prime}$ & $144^{\circ} 03^{\prime}$ & $<1$ & $\mathrm{C}$ & $4740 \pm 130$ & ANU-6623 & $4944(4575-5290)$ & $\mathrm{O}$ & 1 \\
\hline Stainer Rf. & $13^{\circ} 55^{\prime}$ & $143^{\circ} 50^{\prime}$ & $<1$ & $\mathbf{M}$ & $4980 \pm 80$ & ANU-1639 & $5249(4978-5464)$ & $\mathbf{M}$ & 2 \\
\hline King Is. & $14^{\circ} 06^{\prime}$ & $144^{\circ} 20^{\prime}$ & $<1$ & $\mathrm{M}$ & $5110 \pm 105$ & ANU-2323 & $5890(5651-6154)$ & I & 3 \\
\hline Flinders Is. & $14^{\circ} 10^{\prime}$ & $144^{\circ} 15^{\prime}$ & $<1$ & M & $5660 \pm 205$ & ANU-2319 & $6497(6021-6957)$ & I & 3 \\
\hline Bewick Is. & $14^{\circ} 26^{\prime}$ & $144^{\circ} 49^{\prime}$ & $<1$ & M & $6044 \pm 45$ & Wk-17639 & $6404(6282-6537)$ & I & 4 \\
\hline Noble Is. & $14^{\circ} 30^{\prime}$ & $144^{\circ} 36^{\prime}$ & $<1$ & M & $5800 \pm 87$ & ANU-9189 & $6154(5929-6337)$ & I & 5 \\
\hline Carter Rf. & $14^{\circ} 33^{\prime}$ & $145^{\circ} 36^{\prime}$ & $<1$ & $\mathrm{C}$ & $5800 \pm 110$ & GaK-6480 & $6151(5905-6386)$ & $\mathrm{O}$ & 6 \\
\hline Leggatt Is. & $14^{\circ} 33^{\prime}$ & $144^{\circ} 40^{\prime}$ & $<\mathbf{1}$ & $\mathbf{M}$ & $5800 \pm 130$ & ANU-1286 & $6149(5870-6439)$ & $\mathbf{M}$ & 2 \\
\hline Hampton Is. & $14^{\circ} 34^{\prime}$ & $144^{\circ} 52^{\prime}$ & $<\mathbf{1}$ & $\mathbf{M}$ & $4870 \pm 70$ & ANU-1207 & $5106(4874-5292)$ & $\mathbf{M}$ & 2 \\
\hline Yonge Rf. & $14^{\circ} 36^{\prime}$ & $145^{\circ} 37^{\prime}$ & $<1$ & $\mathrm{C}$ & $4960 \pm 80$ & Beta 40806 & $5216(4963-5448)$ & $\mathrm{O}$ & 1 \\
\hline Nymph Is. & $14^{\circ} 39^{\prime}$ & $145^{\circ} 15^{\prime}$ & $<1$ & M & $4750 \pm 69$ & ANU-8959 & $4943(4786-5215)$ & $\mathrm{M}$ & 5 \\
\hline Nymph Is. & $14^{\circ} 39^{\prime}$ & $145^{\circ} 15^{\prime}$ & $<1$ & $\mathbf{M}$ & $3700 \pm 90$ & ANU-1285 & 3557 (3345-3811) & $\mathbf{M}$ & 2 \\
\hline Lizard Is. & $14^{\circ} 39^{\prime}$ & $145^{\circ} 29^{\prime}$ & $<1$ & $\mathrm{C}$ & $-653 \pm 181$ & ANUA25525 & Modern. & M & 7 \\
\hline MacGillivray Rf. & $14^{\circ} 40^{\prime}$ & $145^{\circ} 30^{\prime}$ & $<1$ & $\mathrm{C}$ & $619 \pm 175$ & ANUA26228 & $222(0-474)$ & $\mathrm{M}$ & 7 \\
\hline East Petherbridge & $14^{\circ} 45^{\prime}$ & $145^{\circ} 05^{\prime}$ & $<1$ & $\mathbf{M}$ & $2370 \pm 70$ & ANU-1384 & 1938 (1741-2130) & $\mathrm{M}$ & 2 \\
\hline Long Rf. & $15^{\circ} 03^{\prime}$ & $145^{\circ} 34^{\prime}$ & $<1$ & $\mathrm{C}$ & $4740 \pm 120$ & GaK-6483 & $4944(4607-5280)$ & $\mathrm{M}$ & 6 \\
\hline Lark Pass Rf. & $15^{\circ} 05^{\prime}$ & $145^{\circ} 44^{\prime}$ & $<1$ & $\mathrm{C}$ & $5910 \pm 110$ & GaK-6683 & $6274(5989-6518)$ & $\mathrm{O}$ & 8 \\
\hline Low Wooded Is. & $15^{\circ} 06^{\prime}$ & $145^{\circ} 23^{\prime}$ & $<1$ & $\mathbf{M}$ & $6080 \pm 90$ & ANU-1604 & $6452(6262-6664)$ & $\mathrm{M}$ & 2 \\
\hline Three Is.-3 & $15^{\circ} 07^{\prime}$ & $145^{\circ} 25^{\prime}$ & $<1$ & $\mathrm{C}$ & $4520 \pm 110$ & GaK-7667 & $4644(4347-4935)$ & $\mathrm{M}$ & 8 \\
\hline Ribbon No 5 & $15^{\circ} 22^{\prime}$ & $145^{\circ} 47^{\prime}$ & $<1$ & $\mathrm{C}$ & $5940 \pm 80$ & ANU-3516 & $6308(6113-6469)$ & $\mathrm{O}$ & 9 \\
\hline
\end{tabular}


Table 1 (cont). Radiometric dates from the northern Great Barrier Reef within $1.5 \mathrm{~m}$ of reef surface (modified from Hopley et al., 2007).

\begin{tabular}{|c|c|c|c|c|c|c|c|c|c|}
\hline Location & $\begin{array}{c}\text { Lat. } \\
\mathrm{S} \\
\end{array}$ & $\begin{array}{c}\text { Long. } \\
\text { E } \\
\end{array}$ & $\begin{array}{c}\text { Depth } \\
\text { Below } \\
(\mathrm{MLWS})^{a} \\
\end{array}$ & Material $^{b}$ & $\begin{array}{c}\text { Age } \pm \\
\text { error (yr) } \\
\end{array}$ & $\begin{array}{c}\text { Laboratory } \\
\text { code }\end{array}$ & $\begin{array}{c}\text { Calibrated age } \\
\text { Median probability } \\
(2 \sigma \text { range }) \\
\end{array}$ & $\begin{array}{l}\text { (I) Inner } \\
\text { (M) Mid } \\
\text { (O) Outer } \\
\text { Reef } \\
\end{array}$ & Ref \\
\hline Boulder Rf. & $15^{\circ} 25^{\prime}$ & $145^{\circ} 26^{\prime}$ & $<1$ & $\mathrm{C}$ & $5910 \pm 190$ & CSIRO 234 & $6272(5680-6714)$ & $\mathrm{M}$ & 9 \\
\hline Cairns Rf. & $15^{\circ} 39^{\prime}$ & $145^{\circ} 33^{\prime}$ & $<1$ & $\mathrm{C}$ & $4110 \pm 130$ & GaK-6686 & $4094(3713-4438)$ & M & 8 \\
\hline East Hope Is. & $15^{\circ} 45^{\prime}$ & $145^{\circ} 26^{\prime}$ & $<1$ & $\mathrm{C}$ & $2570 \pm 100$ & GaK-6687 & 2179 (1904-2439) & M & 8 \\
\hline Emmagen Rf. & $16^{\circ} 01^{\prime}$ & $145^{\circ} 29^{\prime}$ & $<1$ & $\mathrm{C}$ & $5390 \pm 60$ & 2567 & $5705(5578-5868)$ & I & 10 \\
\hline Rykers Rf. & $16^{\circ} 02^{\prime}$ & $145^{\circ} 29^{\prime}$ & $<1.5$ & $\mathrm{C}$ & $6860 \pm 60$ & 2570 & $7332(7194-7451)$ & I & 10 \\
\hline Myall Rf. & $16^{\circ} 05^{\prime}$ & $145^{\circ} 30^{\prime}$ & $<1$ & M & $5690 \pm 96$ & ANU-9214 & $6043(5827-6274)$ & I & 5 \\
\hline South Myall Rf. & $16^{\circ} 05^{\prime}$ & $145^{\circ} 30^{\prime}$ & $<1$ & $\mathrm{C}$ & $6150 \pm 70$ & 2564 & $7305(7153-7434)$ & I & 10 \\
\hline Opal Rf.-3 & $16^{\circ} 13^{\prime}$ & $145^{\circ} 53^{\prime}$ & $<1.5$ & $\mathrm{C}$ & $4140 \pm 130$ & GaK-7674 & $4134(3774-4501)$ & M & 8 \\
\hline Yule Point & $16^{\circ} 34^{\prime}$ & $145^{\circ} 31^{\prime}$ & & M & $4475 \pm 125$ & EWY-3 & $5164(4843-5462)$ & I & 3 \\
\hline Michaelmas Rf. & $16^{\circ} 35^{\prime}$ & $146^{\circ} 02^{\prime}$ & $<1$ & $\mathrm{C}$ & $5100 \pm 130$ & GaK-7675 & $5389(5021-5683)$ & M & 8 \\
\hline Thetford Rf. & $16^{\circ} 48^{\prime}$ & $146^{\circ} 12^{\prime}$ & $<1$ & $\mathrm{C}$ & $2680 \pm 120$ & GaK-7681 & $2323(2018-2678)$ & M & 8 \\
\hline Channel Rf. & $16^{\circ} 56^{\prime}$ & $146^{\circ} 27^{\prime}$ & $<1$ & $\mathrm{C}$ & $1930 \pm 110$ & GaK-7683 & $1437(1216-1701)$ & $\mathrm{O}$ & 8 \\
\hline
\end{tabular}

Notes: Only the oldest near-surface (mostly $<1 \mathrm{~m}$ ) age for each site is listed here. Recalibrations were calculated using Calib 7.10 (Stuiver et al., 2017) the InterCal13 dataset and the Marine13 database. A Delta-R value of 52 \pm 31 years was applied to conventional radiocarbon ages; this is the best estimate for the Great Barrier Reef north of Cairns (Lewis et al., 2013). Radiocarbon dates from the northern Great Barrier Reef Expedition are in bold.

${ }^{a}$ it was assumed from observations of contemporary reefs that most reef flat surfaces are close to MLWS, and so this depth class is estimated relative to this datum.

${ }^{b} \mathrm{M}$ denotes microatoll where explicitly stated. C denotes coral material, not specifically identified as microatoll.

${ }^{\mathrm{C}}$ Calibrated ages expressed in years BP where BP is 1950.

References: 1: Hopley (1994), 2: Polach et al. (1978), 3: Chappell et al. (1983), 4: Kench et al. (2012), 5: Zwartz (1995), 6: Hopley (1977), 7: Rees et al. (2006), 8: Hopley (1982), 9: Davies and Hopley (1983), 10: Partain (1988). 
Sea-level data from the GBR outside of the northern region published since Lewis et al. (2013) include radiocarbon and U-series dated microatolls, oysters and upper reef deposits, mostly from the central and southern GBR around the Keppel Islands (Leonard et al., 2016), Capricorn Bunker Group (Harris et al., 2015; Webb et al., 2016), and further south in Moreton Bay (Leonard et al., 2013) (see Figure 3, Table 2). Most of this new evidence from inner to mid-shelf reefs suggests the highstand was achieved between 5500 and 7000 cal. yr ago, though evidence from the Keppel Islands (Leonard et al., 2016) suggest that maximum Holocene sea level in the southern GBR occurred after $6200 \mathrm{cal}$. yr BP and was lower than the 1.0 to $1.5 \mathrm{~m}$ more widely reported.

Further north, evidence from the central GBR includes microatoll data from a range of reefs near Bowen (Bramston, Stone and Middle Island reefs), and from Magnetic Island near Townsville. Results from these studies suggest a highstand around $0.9 \mathrm{~m}$ above present about $6900 \mathrm{cal}$. yr BP at Middle Island (Ryan et al., 2016b), which accords well with the highstand age and elevation based on U-series dated fossil microatolls at Magnetic Island $180 \mathrm{~km}$ further north west (Yu and Zhao, 2010). Elevations and ages of fossil microatolls at Stone Island similarly suggest a high sea level around $1 \mathrm{~m}$ above present, but indicate it occurred $\sim 6700-5900$ cal. yr BP (Ryan et al., 2016c). The new ages from Stone Island closely match recalibrated ages for microatolls collected at the same location by Chappell et al., (1983) (see Table 2). An age of $4256 \pm 14$ cal. yr was established for a microatoll growing approximately $0.6 \mathrm{~m}$ above living coral at Bramston Reef, a mainland attached fringing reef, just $3 \mathrm{~km}$ from Stone Island (Ryan et al., 2016a) which suggests that sea level had begun to fall by this time. This data agrees with the recent evidence from Bewick Island (Kench et al., 2012) but is at odds with claims that the highstand persisted until 2000-3000 years ago (Lewis et al., 2008) and that it fell from approximately $1 \mathrm{~m}$ higher to its present position between 1200 and 800 cal. yr BP (Lewis et al., 2015).

In summary, despite broad similarities in results from the northern, central and southern sectors of the GBR, the exact elevations, timing and duration of the high sea level, and the pattern of subsequent changes toward present continue to defy precise definition. This is largely because the relationships between different sea-level indicators, and the water level they indicate at different locations, are not adequately resolved. Additionally, geographic variations in hydro-isostatic response are rarely considered, and issues of interpretation and reconciliation of different types of field evidence remains a subject of debate.

\section{CONTINUED CONTENTIONS AND UNRESOLVED UNCERTAINTIES}

Since the 1973 expedition hydro-isostasy has been refined as an explanation for along and across shelf differences in relative sea-level histories, and technological advances have improved the precision with which the ages and elevations of sea-level indicators can be measured. However, despite these advances the details of Holocene sea-level history remain controversial for many parts of the Great Barrier Reef, with divergent views persisting particularly regarding:

a) the elevation, timing and duration of the mid-Holocene sea level highstand along the inner shelf; and

b) the pattern and timing of sea-level fall from this highstand to present.

These disputes can be attributed to both a lack of conclusive data or conflicting interpretations of the available evidence, which in many cases includes data derived from a number of sea-level indicators, and from different locations. Resolution of these controversies is beyond the scope of this paper, but below we outline some of the key issues that underpin the ongoing uncertainties related to two of the major areas of contention. 


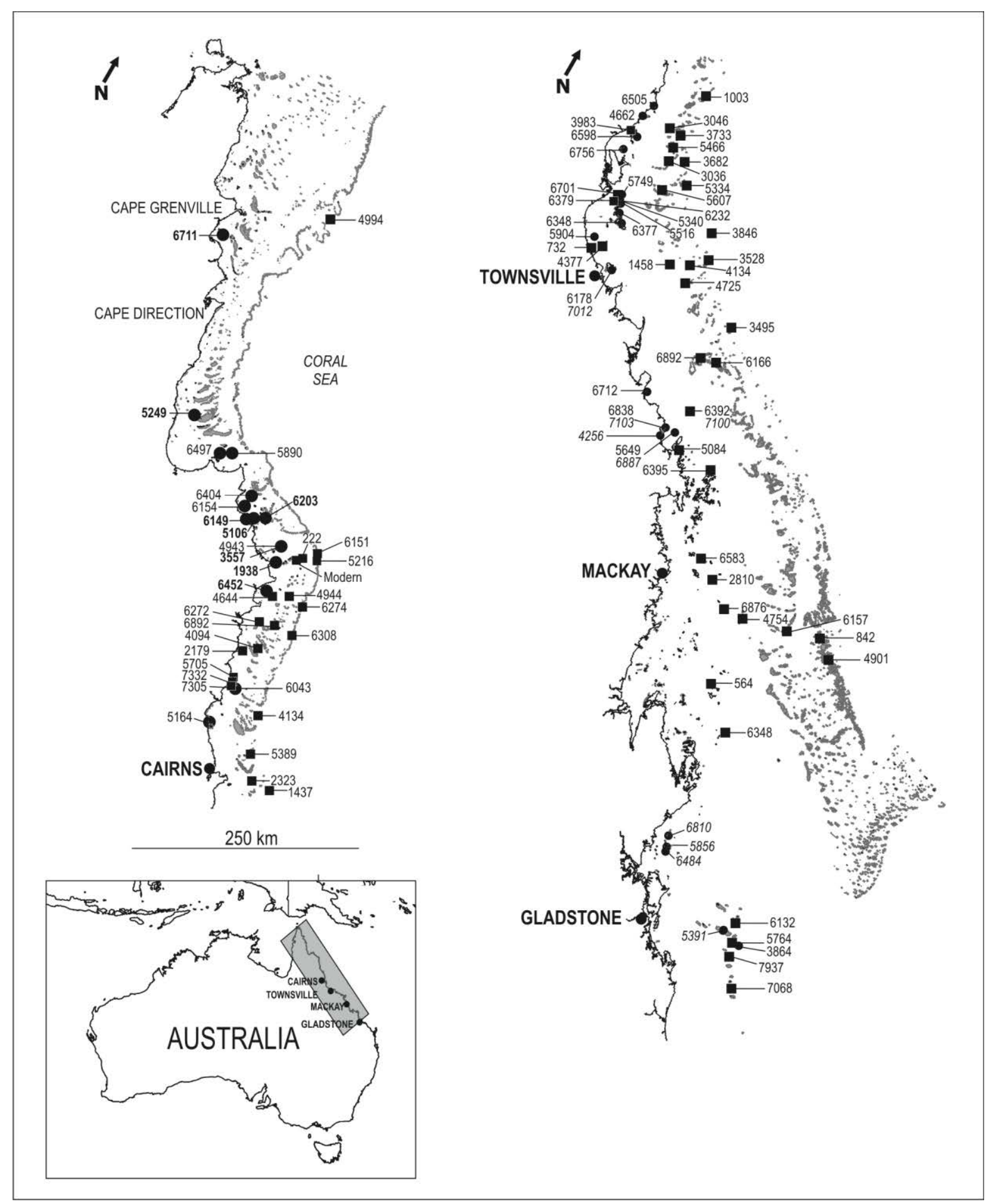

Figure 3. Map showing the oldest reef top ages from sites across the Great Barrier Reef. Dates from the northern Great Barrier Reef (GBR) collected by the Stoddart expedition and recalibrated are shown in bold. Ages determined using U-series dating are shown in italics. Ages depicted are shown in detail in Tables 1 (northern GBR) and 2 (southern GBR). 
Table 2. Radiometric dates from the central and southern Great Barrier Reef within $1.5 \mathrm{~m}$ of reef surface (modified from Hopley et al., 2007).

\begin{tabular}{|c|c|c|c|c|c|c|c|c|c|}
\hline Location & $\begin{array}{l}\text { Lat. } \\
\text { S }\end{array}$ & $\begin{array}{c}\text { Long. } \\
\text { E }\end{array}$ & $\begin{array}{c}\text { Depth } \\
\text { below } \\
(\text { MLWS) }\end{array}$ & Material $^{\mathrm{b}}$ & $\begin{array}{c}\text { Age } \pm \\
\text { error (yr) }\end{array}$ & $\begin{array}{c}\text { Laboratory } \\
\text { code }\end{array}$ & $\begin{array}{c}\text { Calibrated age }^{\mathrm{c}} \\
\text { Median probability } \\
(2 \sigma \text { range })\end{array}$ & $\begin{array}{c}\text { I Inner } \\
\text { M Mid } \\
\text { O Out } \\
\text { Reef } \\
\end{array}$ & Ref \\
\hline Hedley Rf & $17^{\circ} 14^{\prime}$ & $146^{\circ} 28^{\prime}$ & $<1.5$ & $\mathrm{C}$ & $1460 \pm 110$ & $\mathrm{GaK}-7686$ & $1003(770-1237)$ & $\mathrm{M}$ & 1 \\
\hline Lindquist Rf & $17^{\circ} 39^{\prime}$ & $146^{\circ} 09^{\prime}$ & $<1$ & M & $6090 \pm 90$ & ANU-5676 & $6505(6300-6703)$ & I & 2 \\
\hline Potter Rf. & $17^{\circ} 42^{\prime}$ & $146^{\circ} 32^{\prime}$ & $<1$ & $\mathrm{C}$ & $3800 \pm 110$ & ARL-235 & $3733(3447-4021)$ & M & 2 \\
\hline Ellison Rf. & $17^{\circ} 43^{\prime}$ & $146^{\circ} 24^{\prime}$ & $<1$ & $\mathrm{C}$ & $3530 \pm 60$ & Wk-1396 & $3046(3248-3556)$ & M & 2 \\
\hline King Rf & $17^{\circ} 46^{\prime}$ & $146^{\circ} 08^{\prime}$ & $<1$ & M & $4481 \pm 30$ & KR-AMA-2 & $4662(4543-4786)$ & I & 3 \\
\hline Taylor Rf. & $17^{\circ} 50^{\prime}$ & $146^{\circ} 33^{\prime}$ & $<1$ & $\mathrm{C}$ & $5130 \pm 140$ & GaK-11082 & $5466(5072-5783)$ & M & 2 \\
\hline 17065 Rf. & $17^{\circ} 53^{\prime}$ & $146^{\circ} 44^{\prime}$ & $<1$ & $\mathrm{C}$ & $3760 \pm 100$ & Wk-1393 & $3682(3432-3946)$ & $\mathrm{O}$ & 2 \\
\hline Dunk Is. & $17^{\circ} 58^{\prime}$ & $146^{\circ} 10^{\prime}$ & $<1$ & M & $6175 \pm 100$ & EWD-1 & $6598(6372-6846)$ & I & 4 \\
\hline Lugger Bay & $17^{\circ} 58^{\prime}$ & $146^{\circ} 08^{\prime}$ & $<1$ & $\mathrm{C}$ & $3993 \pm 45$ & Wk-16745 & $3983(3848-4123)$ & I & 5 \\
\hline Moss Rf. & $17^{\circ} 58^{\prime}$ & $146^{\circ} 36^{\prime}$ & $<1$ & $\mathrm{C}$ & $3230 \pm 140$ & GaK-8934 & $3036(2731-3363)$ & $\mathrm{O}$ & 1 \\
\hline Barnett Shoal & $18^{\circ} 03^{\prime}$ & $146^{\circ} 54^{\prime}$ & $\sim 1$ & $\mathrm{C}$ & $5020 \pm 160$ & GaK-8933 & $5334(4889-5670)$ & M & 1 \\
\hline Goold Is. & $18^{\circ} 11^{\prime}$ & $146^{\circ} 10^{\prime}$ & $<1$ & M & $6305 \pm 140$ & EWG-1 & $6756(6432-7112)$ & I & 4 \\
\hline Britomart Rf. & $18^{\circ} 14^{\prime}$ & $146^{\circ} 44^{\prime}$ & $<1.5$ & $\mathrm{C}$ & $5255 \pm 65$ & Beta 1055 & $5607(5453-5746)$ & M & 6 \\
\hline Myrmidon Rf. & $18^{\circ} 15^{\prime}$ & $147^{\circ} 23^{\prime}$ & $<1$ & $\mathrm{C}$ & $3890 \pm 50$ & Wk-427 & $3846(3684-3986)$ & $\mathrm{O}$ & 7 \\
\hline Bowl Rf. & $18^{\circ} 28^{\prime}$ & $147^{\circ} 33^{\prime}$ & $<1$ & $\mathrm{C}$ & $3640 \pm 60$ & Wk-591 & $3528(3378-3680)$ & $\mathrm{O}$ & 7 \\
\hline Hazard Bay & $18^{\circ} 36^{\prime}$ & $146^{\circ} 29^{\prime}$ & $<1$ & M & $5170 \pm 69$ & ANU-8298 & $5516(5324-5644)$ & I & 8 \\
\hline Iris Point & $18^{\circ} 36^{\prime}$ & $146^{\circ} 29^{\prime}$ & $<1$ & $\mathrm{C}$ & $6260 \pm 120$ & ARL-201 & $6701(6407-6986)$ & I & 9 \\
\hline Iris Point & $18^{\circ} 36^{\prime}$ & $146^{\circ} 29^{\prime}$ & $<1$ & M & $5390 \pm 78$ & ANU-6953 & $5749(5586-5902)$ & I & 8 \\
\hline Pioneer Bay & $18^{\circ} 36^{\prime}$ & $146^{\circ} 29^{\prime}$ & $<1$ & $\mathrm{C}$ & $5970 \pm 100$ & SUA-1679 & $6379(6182-6613)$ & I & 10 \\
\hline Pioneer Bay & $18^{\circ} 36^{\prime}$ & $146^{\circ} 29^{\prime}$ & $<1$ & M & $5830 \pm 87$ & ANU_7901 & $6232(6002-6406)$ & I & 8 \\
\hline Grub Rf. & $18^{\circ} 38^{\prime}$ & $147^{\circ} 26^{\prime}$ & $<1$ & $\mathrm{C}$ & $4100 \pm 80$ & SUA-1907 & $4134(3908-4375)$ & M & 10 \\
\hline Fantome Is. & $18^{\circ} 40^{\prime}$ & $146^{\circ} 31^{\prime}$ & $<1$ & M & $5970 \pm 90$ & ANU-2464 & $6377(6198-6590)$ & I & 4 \\
\hline Great Palm Is. & $18^{\circ} 42^{\prime}$ & $146^{\circ} 36^{\prime}$ & $<1$ & M & $5940 \pm 90$ & $\mathrm{GP} / 3$ & $6348(6168-6559)$ & I & 4 \\
\hline Keeper Rf. & $18^{\circ} 45^{\prime}$ & $147^{\circ} 16^{\prime}$ & $<1$ & $\mathrm{C}$ & $1920 \pm 80$ & $\mathrm{GaK}-7272$ & $1458(1287-1640)$ & M & 1 \\
\hline
\end{tabular}


Table 2 (cont). Radiometric dates from the central and southern Great Barrier Reef within $1.5 \mathrm{~m}$ of reef surface (modified from Hopley et al., 2007).

\begin{tabular}{|c|c|c|c|c|c|c|c|c|c|}
\hline Wheeler Rf. & $18^{\circ} 48^{\prime}$ & $147^{\circ} 31^{\prime}$ & $<1.5$ & $\mathrm{C}$ & $4550 \pm 90$ & SUA-1528 & $4725(4482-4964)$ & M & 10 \\
\hline Viper Rf. & $18^{\circ} 50^{\prime}$ & $148^{\circ} 09^{\prime}$ & $<1$ & $\mathrm{C}$ & $3610 \pm 60$ & Wk-438 & $3495(3350-3642)$ & $\mathrm{O}$ & 7 \\
\hline Herald Is. & $19^{\circ} 02^{\prime}$ & $146^{\circ} 38^{\prime}$ & $<1$ & $\mathrm{BR} / \mathrm{C}$ & $4280 \pm 100$ & GaK-2014 & 4377 (4084-4677) & I & 11 \\
\hline Rattlesnake Is. & $19^{\circ} 02^{\prime}$ & $146^{\circ} 30^{\prime}$ & $<1$ & $\mathrm{M}$ & $5530 \pm 130$ & GaK-7688 & $5904(5613-6191)$ & I & 1 \\
\hline Paluma Shoals & $19^{\circ} 05^{\prime}$ & $146^{\circ} 34^{\prime}$ & $<1$ & $\mathrm{C}$ & $1200 \pm 45$ & Wk-10800 & $732(649-855)$ & I & 12 \\
\hline Magnetic Is, & $19^{\circ} 09^{\prime}$ & $146^{\circ} 52^{\prime}$ & $<1$ & $M$ & $7012 \pm 22$ & $G B R-H 3$ & $7012 \pm 22$ & I & 13 \\
\hline Magnetic Is. & $19^{\circ} 09^{\prime}$ & $146^{\circ} 52^{\prime}$ & $<1$ & M & $5775 \pm 70$ & EWM/4 & $6178(5984-6311)$ & I & 4 \\
\hline Darley Rf. & $19^{\circ} 12^{\prime}$ & $148^{\circ} 15^{\prime}$ & $<1$ & $\mathrm{C}$ & $6070 \pm 130$ & GaK-7025 & $6166(5888-6440)$ & M & 1 \\
\hline Stanley Rf. & $19^{\circ} 16^{\prime}$ & $148^{\circ} 06^{\prime}$ & $<1$ & $\mathrm{C}$ & $6420 \pm 160$ & $\mathrm{GaK}-8931$ & $6892(6516-7249)$ & M & 1 \\
\hline Holbourne Is. & & & & $C$ & $7100 \pm 20$ & $H I-P 1-110$ & $7100 \pm 20$ & M & 4 \\
\hline Holbourne Is. & $19^{\circ} 44^{\prime}$ & $148^{\circ} 22^{\prime}$ & $<1$ & $\mathrm{C}$ & $5980 \pm 120$ & GaK-4236 & $6392(6144-6670)$ & M & 15 \\
\hline Camp Is. & $19^{\circ} 52^{\prime}$ & $147^{\circ} 53^{\prime}$ & $<1$ & M & $6270 \pm 110$ & EWC/1 & $6712(6440-6977)$ & I & \\
\hline Middle Is & & & & $C$ & $6887 \pm 27$ & $M I-P 2-55$ & $6887 \pm 27$ & I & \\
\hline Middle Is. & $19^{\circ} 59^{\prime}$ & $148^{\circ} 22^{\prime}$ & $<1$ & $\mathrm{C}$ & $5290 \pm 120$ & GaK-4894 & $5649(5387-5907)$ & I & \\
\hline Stone Is. & & & & $M$ & $7103 \pm 40$ & SI-S-FMA-9 & $7103 \pm 40$ & I & 1 \\
\hline Stone Is. & $20^{\circ} 02^{\prime}$ & $148^{\circ} 16^{\prime}$ & $<1$ & M & $6375 \pm 110$ & EWS/1 & $6838(6587-7137)$ & I & 4 \\
\hline Bramston $R f$ & & & & $M$ & $4256 \pm 14$ & $B R-F M A-3$ & $4256 \pm 14$ & I & 1 \\
\hline Hayman Is. & $20^{\circ} 03^{\prime}$ & $148^{\circ} 53^{\prime}$ & $<1.5$ & $\mathrm{C}$ & $5990 \pm 80$ & Beta 83809 & $6395(6245-6597)$ & I & 16 \\
\hline Hydeaway B & $20^{\circ} 04^{\prime}$ & $148^{\circ} 29^{\prime}$ & $<1$ & $\mathrm{C}$ & $4810 \pm 45$ & Wk-16738 & $5084(4920-5256)$ & I & 17 \\
\hline Molar Rf. & $20^{\circ} 38^{\prime}$ & $150^{\circ} 48^{\prime}$ & $<1$ & $\mathrm{C}$ & $1310 \pm 100$ & GaK-7268 & $842(657-1047)$ & $\mathrm{O}$ & 1 \\
\hline Cockatoo Rf. & $20^{\circ} 45^{\prime}$ & $151^{\circ} 00^{\prime}$ & $<1$ & $\mathrm{C}$ & $4670 \pm 80$ & SUA-2114 & $4901(4618-5222)$ & $\mathrm{O}$ & 18 \\
\hline Cockermouth. & $20^{\circ} 47^{\prime}$ & $149^{\circ} 23^{\prime}$ & $<1$ & $\mathrm{C}$ & $6160 \pm 120$ & ANU-6631 & $6583(6308-6857)$ & I & . \\
\hline Gable Rf. & $20^{\circ} 47^{\prime}$ & $150^{\circ} 30^{\prime}$ & $<1$ & $\mathrm{C}$ & $5760 \pm 80$ & SUA-1774 & $6157(5947-6309)$ & M & 18 \\
\hline Scawfell Is. & $20^{\circ} 52^{\prime}$ & $149^{\circ} 36^{\prime}$ & $<1.5$ & $\mathrm{C}$ & $3040 \pm 80$ & Beta-33213 & $2810(2655-3030)$ & $\mathrm{M}$ & 1 \\
\hline Redbill Is. & $20^{\circ} 58^{\prime}$ & $150^{\circ} 05^{\prime}$ & $<1.5$ & $\mathrm{C}$ & $4570 \pm 150$ & $\mathrm{GaK}-7820$ & $4754(4386-5217)$ & M & 24 \\
\hline Penrith Is. & $21^{\circ} 01^{\prime}$ & $149^{\circ} 53^{\prime}$ & $<1.5$ & $\mathrm{C}$ & $6400 \pm 80$ & Beta-33201 & $6876(6664-7121)$ & M & 1 \\
\hline Percy Is. & $21^{\circ} 42$ & $150^{\circ} 16^{\prime}$ & $<1$ & $\mathrm{C}$ & $970 \pm 80$ & Beta-33208 & $564(425-698)$ & I & 1 \\
\hline High Peak Is. & $21^{\circ} 57^{\prime}$ & $150^{\circ} 41^{\prime}$ & $<1$ & $\mathrm{C}$ & $5930 \pm 100$ & Beta-41067 & $6348(6119-6607)$ & I & 18 \\
\hline One Tree Rf & $23^{\circ} 05^{\prime}$ & $152^{\circ} 08^{\prime}$ & $<1$ & M & $3895 \pm 40$ & OZP788 & $3864(3693-4038)$ & $\mathrm{O}$ & 1 \\
\hline Humpy Is. & $23^{\circ} 12^{\prime}$ & $150^{\circ} 58^{\prime}$ & $<1$ & $M$ & $6810 \pm 25$ & HUMP010 & $6810 \pm 25$ & I & 2 \\
\hline
\end{tabular}


Table 2 (cont). Radiometric dates from the central and southern Great Barrier Reef within $1.5 \mathrm{~m}$ of reef surface (modified from Hopley et al., 2007

\begin{tabular}{|c|c|c|c|c|c|c|c|c|c|}
\hline N. Keppel Is. & $23^{\circ} 12^{\prime}$ & $150^{\circ} 53^{\prime}$ & $<1$ & $M$ & $5856 \pm 26$ & NKI012 & $5856 \pm 26$ & I & 20 \\
\hline Great Keppel & $23^{\circ} 11^{\prime}$ & $150^{\circ} 56^{\prime}$ & $<1$ & $M$ & $6484 \pm 30$ & GKI009 & $6484 \pm 30$ & I & 20 \\
\hline Wreck Rf. & $23^{\circ} 20^{\prime}$ & $151^{\circ} 58^{\prime}$ & $<1$ & $\mathrm{C}$ & $5730 \pm 70$ & Wk-369 & $6132(5936-6287)$ & $\mathrm{O}$ & 7 \\
\hline Heron $R f^{d}$ & $23^{\circ} 27^{\prime}$ & $151^{\circ} 55^{\prime}$ & $<1$ & $C$ & $5391 \pm 25$ & WH3-6 & $5391 \pm 25$ & $\mathrm{O}$ & 21 \\
\hline One Tree Is & $23^{\circ} 30^{\prime}$ & $152^{\circ} 04^{\prime}$ & $<1$ & $\mathrm{C}$ & $5390 \pm 180$ & Wk-253 & $5764(5382-6178)$ & $\mathrm{O}$ & 7 \\
\hline Fitzroy Rf. & $23^{\circ} 38^{\prime}$ & $152^{\circ} 09^{\prime}$ & $<1$ & $\mathrm{C}$ & $7480 \pm 130$ & Wk-331 & $7937(7652-8216)$ & $\mathrm{O}$ & 7 \\
\hline Fairfax Rf. & $23^{\circ} 52^{\prime}$ & $152^{\circ} 22^{\prime}$ & $<1.5$ & $\mathrm{C}$ & $6560 \pm 70$ & Wk-303 & $7068(6872-7249)$ & $\mathrm{O}$ & 7 \\
\hline
\end{tabular}

Notes: Only the oldest near-surface age for each site is listed here, except where new U-series or accelerator mass spectrometer radiocarbon ages are available to compare with conventional ages established in the 1970s and 1980s. Recalibrations were calculated using Calib 7.10 (Stuiver et al., 2017) using the InterCal13 dataset and the Marine13 database. A Delta-R value of $52 \pm 31$ years or $12 \pm 6$ was applied to conventional radiocarbon ages north of Cairns or between Cairns and Mackay respectively (Lewis et al., 2013). A Delta-R value of $4 \pm 40$ was applied to conventional radiocarbon ages south of Mackay following Druffel and Griffin (2004). Where an older age for a reef top is available than for a microatoll both ages are presented. Where both radiocarbon and uranium series ages are available for a site, both are also listed, with the uranium-series ages presented in italics.

${ }^{a}$ it was assumed from observations of contemporary reefs that most reef flat surfaces are close to MLWS, and so this depth class is estimated relative to this datum.

${ }^{b} \mathrm{M}$ denotes microatoll where explicitly stated. $\mathrm{C}$ denotes coral material, not specifically identified as microatoll.

${ }^{\mathrm{C}}$ Calibrated ages expressed in years BP where BP is 1950.

${ }^{d}$ At Heron Island this was the most likely in situ coral specimen dated.

References: 1: Hopley (1982), 2: Graham (1993), 3; Roche et al. (2014), 4: Chappell et al. (1983), 5: Perry and Smithers (2006), 6: Johnson et al. (1984), 7: Peter Davies pers. comm., 8: Zwartz (1995), 9: Barnes (1984), 10: Hopley (1983a), 11: Hopley (1971), 12: Smithers and Larcombe (2003), 13: Yu and Zhao (2010), 14: Ryan (2016), 15: Hopley (1975), 16: Kan et al. (1997), 17: Smithers (unpub), 18: Kleypas (1991), 19: Harris et al. (2015), 20: Leonard et al. (2016), 21: Webb et al. (2016). 


\section{Holocene High Sea Level Elevation, Timing, Duration and Geographical Extent}

As already outlined, it is impossible to define a single sea-level history applicable over the entire Great Barrier Reef. Instead geographical differences in the width of the continental shelf and hydroisostatic response to the postglacial transgression result in spatial variations in the amplitude, timing and duration of the Holocene highstand (Hopley et al., 2007). Hydro-isostatic models predict that the amplitude of the mid-Holocene reef surfaces should vary by around $1.5 \mathrm{~m}$ across the shelf, with the highest levels reached earliest on the inner shelf (Nakada and Lambeck, 1989; Lambeck and Nakada, 1990). Accordingly, reported variations in the maximum age and elevation reached by reefs across (and along) the shelf are not necessarily contradictory; they may be largely explained by a spatially variable hydro-isostatic response. However, conflicting views of the details of Holocene sea level have been presented from discrete locations where a uniform hydro-isostatic influence might be assumed (e.g. inner shelf central GBR). Typically, such differences of opinion reflect the use of different types of evidence or new interpretations of existing evidence.

There is also scant recognition of the fact that precisely defining the highstand requires that a sea level indicator growing in the past is well preserved and able to be surveyed and sampled for dating. Reef growth on the GBR is dominated by 'catch-up' reefs that lagged behind the rising seas, and only reached the sea surface once the rate of rise slowed or stabilized (Davies and Hopley, 1983; Hopley et al., 2007). Although reef core evidence demonstrates that many inner shelf reefs grew rapidly, it is possible that the reefs reached the sea surface after the maximum sea level had been achieved. In such cases the sea-level evidence would under-estimate the highstand maximum. It is also likely that the highstand zenith may be under-estimated at some sites because the samples required to define it are not obvious or readily accessible. For example, beach ridge accretion, storm deposits or indeed reef islands and cays may bury the oldest and highest sea level indicators in the locality. In these circumstances, data from a particular site might suggest a highstand peak lower than expressed elsewhere in the region, or below that predicted by hydro-isostatic models. Conversely, sea-level can be overestimated if moating of microatolls for instance is not recognized (Scoffin and Stoddart, 1978; Stoddart and Scoffin, 1979; Hopley, 1982). Timetransgressive changes in tide and storm exposure influenced by both local relative sea-level change and the approach of seaward reefs to sea level introduce further uncertainties (Hopley, 1984). Nonetheless, when the weight of observational evidence now accumulated along the length of the inner GBR is viewed in concert with geophysical model outputs that broadly agree, the reality of a 1.0 to $1.5 \mathrm{~m}$ highstand can be confidently accepted, although its timing remains more controversial (e.g. Yu and Zhao, 2010; Ryan et al., 2016a; Sloss et al., 2007; Lewis et al., 2013).

\section{Nature of Sea Level Fall to Present - Smooth or Oscillating?}

A second contentious issue also dates back over five decades to when Fairbridge (1961) proposed that sea level oscillated up and down as it fell from a mid-Holocene high towards its present position. Whilst the NGBR expedition results were ambiguous on this point, later analyses based on microatolls in the northern and central GBR by Chappell (1983) and Chappell et al. (1983) demonstrated that it was more probable that sea level fell smoothly to present as no evidence of fluctuations were detected that exceeded observational noise in their data. Over three decades later this view of a smoothly falling sea level was also endorsed by Lambeck et al. (2010) despite a resurgence of support for multiple rapid Holocene sea-level oscillations of around $1 \mathrm{~m}$ (e.g. Baker and Haworth, 2000; Baker et al., 2001; Lewis et al., 2008). However, as noted by Lambeck et al. (2010), these studies often ignore the importance of isostatic contributions to relative sea level and they frequently combine data from different sites into a single record such that spatial differences in hydro-isostatic response may generate 'apparent' oscillations. Moreover, GBR coral elevation data corrected for site-specific modelled hydro-isostatic responses and reduced to a common reference datum also fail to identify any oscillations beyond the error limits of the data (Lambeck et al., 2010). 
Fluctuations in sea level are commonly defined using data from a number of different indicators and a range of microatoll genera and/or field contexts, often with equivocal or inconsistent relationships to a particular tidal level (e.g. see Perry and Smithers, 2011 supplementary). Indeed, several papers arguing for oscillations combine evidence from a broad range of indicators for justification (e.g. Larcombe et al., 1995; Lewis et al., 2008; Leonard et al., 2016). In contrast, the Chappell (1983) and Chappell et al. (1983) conclusion that post-highstand sea level fell smoothly to its present level was based on dated and surveyed fossil Porites (only) microatolls sampled across 11 sites, where living microatolls grew at the reef edge and progressively older microatolls were distributed back across the emergent reef flats. In this context it is reasonable to affirm that fossil and modern microatolls were undisturbed and responded to an equivalent tidal level. Given the consistency and quality of this evidence, as well as the replicability of the results across a wide range of sites, it is difficult to dismiss the conclusion of a smooth post-high sea level fall (see also Hopley et al., 2007; Perry and Smithers, 2010; Lambeck et al., 2010) though this remains a contentious issue (e.g. Lewis et al., 2015).

Resolution of these two ongoing controversies requires quality data systematically collected, reported and agreed to. Technological advances in both geodetic survey and radiometric dating, significantly improved sea-level indicator elevation and age precisions and accuracies, and the ease with which data can be collected. Satellite altimetry has also enhanced capacity to better determine tidal datum at synoptic scales, and thus the ability to reconcile geodetic elevations to tidal levels that control the elevations of most sea-level indicators. However, careful field interpretation remains critical, and without it precise and accurate measurements are clearly of little use. Although technological advances allow more and more precise data to be collected, the challenge remains to ensure that these data relate to correctly interpreted field features. Such expertise requires field experience beyond the operation of equipment, and is both difficult to acquire and verify. It is, however, crucial to reconstructing robust sealevel histories.

\section{DISCUSSION AND CONCLUSION}

The team assembled by David Stoddart for the 1973 NGBR expedition over four decades ago operated without many of the sophisticated technologies available today but brought immense field experience to the project. Collectively, expedition participants had a wealth of prior field-work on reefs in the Indian Ocean (Aldabra, Chagos, Seychelles, Maldives), the Caribbean (Bahamas, Barbados, Belize) in the central and southwest Pacific (Caroline Islands, Cook Islands, Marshall Islands, Solomon Islands, Tuvalu), and on the Great Barrier Reef itself. As noted earlier however, the same team brought to the expedition strongly opposing views on the pattern of sea level change during the Holocene (Bloom, 1970; Hopley, 1971; Gill and Hopley, 1972; Thom et al., 1969; Thom et al., 1972). The value of having such a diverse, but experienced team had been recognized a few years earlier by the French geomorphologist Andre Guilcher when concluding a review of Pleistocene and Holocene sea-level changes and problems he wrote: "Our conclusion is that the problem of the post-glacial high sea level remains open; a better approach would be made possible in many cases by means of visits to conflicting sites by parties including scientists of opposite opinions" (Guilcher, 1969, p. 91).

That approach was followed during the four months of 1973 NGBR expedition. Shared field experiences together with confidence in the post-expedition laboratory work, analysis and radiometric determinations produced an agreed sea-level history for the northern province of the Great Barrier Reef. Later, the expedition results contributed to the recognition that there is not just one exclusive sea-level history applicable to the whole of the GBR (or globally), but that patterns of sea-level change are relative to a particular site or region and relative to present sea level at that site or region (Bloom, 1977; Hopley and Thom, 1983).

The foregoing analysis suggests that the investigation of sea-level history on the northern GBR during the Stoddart expedition was pioneering in many ways. Not only did it include 'scientists of opposite opinions', but it provided an early, and comprehensive, assessment of the appropriateness of a number of geomorphological and biological palaeo-sea level indicators calibrated to modern tidal levels. 96 
The expedition also demonstrated that the upper surfaces of coral microatolls contain clear water level signals, such that now they are regarded as the most appropriate contemporary and past sea level recorders in coral reef regions. In the northern GBR microatolls provided robust evidence that relative sea level on the inner shelf first reached present sea level around 6000 years ago, and shortly thereafter passed above that level to reach a maximum elevation of about $1.3 \mathrm{~m}$ around 3,500-4000 yr B.P. Sea level in the region has fallen since, although the expedition could not provide any conclusive evidence on the nature or precise timing of the fall, or on the achievement of modern sea level. Nevertheless, the sea-level history established by the 1973 expedition has not been fundamentally challenged, though the dates have been modified through the application of recent ${ }^{14} \mathrm{C}$ recalibration techniques, resulting in a backward temporal shift of the initial chronology.

At the time of the 1973 expedition the application of water loading on continental shelves resulting from the transgression of the sea from the last glacial maximum was in its infancy though the expedition's results provided evidence to underpin the early investigations of hydro-isostatic influences on relative sea level, reef surface morphology and elevation. It also offered a geophysical mechanism to account for spatial differences in sea-level history. Recognition that hydro-isostasy can largely explain geographic variations in relative sea level along and across the GBR - initially tested on the 1973 expedition results - is now well verified although its implications are often overlooked both by sea-level researchers and reef managers. Whilst it was reasonable to suggest in the expedition report that the 'hydro-isostatic factor is generally neglected' (Thom and Chappell, 1978, p.189) there is less excuse for such neglect now. That the inner shelf of the GBR has been upwarped by hydro-isostatic processes means that many inner shelf reefs reached the common sea level isobase relatively early and subsequently became emergent with deteriorated reef flats. For example, the lack of coral cover and slow recovery rates observed on some inner reefs following disturbances are not always symptomatic of human impacts, but can be a consequence of the reef's sea-level history (Hopley et al., 2007; Morgan et al., 2016; Ryan et al., 2016a).

There are two other points from the 1973 expedition that have contemporary relevance. First, many of the problems described in the 1973 expedition report 'are common to all workers interested in documenting late Holocene sea-level history but [they] are rarely mentioned or acknowledged' (McLean et al., 1978: $\mathrm{p}$ 171). These relate to the checklist of items noted in the earlier section on sea-level indicator precision and reliability as well as to the need to state error terms and assumptions, which are inconsistently reported in much of the recent literature on GBR sea levels.

Second, in the introduction to the 1973 expedition report Stoddart noted, with reference to Holocene sea level, that there was controversy over:

"the date at which sea level first reached its present level, and its subsequent behaviour. With respect to this last period, arguments have been adduced for sea level stability over the last few thousand years; for continuing but decelerating transgression; and for oscillation both above and below present level” (Stoddart, 1978, p.5)

These issues have still not been fully resolved. As Lewis et al. (2013) concluded, many of the issues which challenged sea-level researchers in the past remain contentious including: (1) exactly when sea level first achieved its present level; (2) the elevation reached during the Holocene highstand; (3) whether sea level fell smoothly or irregularly from that high; (4) how long the high sea level persisted; and (5) whether sea level oscillated during the highstand or was relatively stable (Lewis et al., 2013, p.115-116). Whilst the 1973 NGBR expedition provided strong evidence for points (1) and (2) that have stood the test of time, the results were more ambiguous regarding points (3) to (5), although with reference to (4) the expedition report notes 'it would appear that for a substantial portion of the last 6000 years sea level has been above its present position for longer than it has been below' (McLean, et al., 1978, p.185).

Finally, it is worth recalling that the 'The main aim of the expedition was to elucidate the recent history of the reefs, especially in response to Holocene sea level change' (Stoddart, 1978, p.5). In this 
paper we have reflected on that statement and on the contribution of the 1973 expedition to Holocene sea level research on the Great Barrier Reef as well as on the more than four decades of debate on this topic following the expedition. However, whilst we have covered the expedition's legacy on Holocene sea level, we must conclude that the main aim of the expedition - 'to elucidate the recent history of the reefs' - still remains imperfectly addressed.

\section{ACKNOWLEDGEMENTS}

This paper has benefitted greatly from discussions and experiences on many reefs, held with many colleagues and students, over many years. We are particularly grateful to Stephen Lewis and Emma Ryan for sharing their insights into sea level on the Great Barrier Reef with us. However, we dedicate this paper to the memory of David Stoddart who both directly and indirectly has influenced all of our research into the linkages between coral reef geomorphology and past and contemporary sea levels. DH and RM were members of the Stoddart Expedition in 1973, while SS was a post-graduate student of one of David Stoddart's PhD students Colin Woodroffe.

\section{REFERENCES}

Abe, N., 1937. Ecological Survey of Iwayama Bay, Palao. Palao Tropical Biological Station Studies 1, 217-324.

Baker, R. G. V. and Haworth, R. J., 2000. Smooth or oscillating late Holocene sea-level curve? Evidence from the palaeo-zoology of fixed biological indicators in east Australia and beyond. Marine Geology, 163(1-4): 367-386.

Baker, R. G. V., Haworth, R. J., Flood, P. G., 2001. Inter-tidal fixed indicators of former Holocene sea levels in Australia: a summary of sites and a review of methods and models. Quaternary International 5, 257-273.

Belperio, A., 1979. Negative evidence for a mid-Holocene high sea level along the coastal plain of the Great Barrier Reef province. Marine Geology 32, M1-M9.

Bird, E. C. F., 1971. The fringing reefs near Yule Point, North Queensland. Australian Geographical Studies 9, 107-115.

Bloom, A. L., 1967. Pleistocene shorelines: A new test of isostasy. Bulletin of the Geological Society of America 78, 1477-1494.

Bloom, A. L. 1970. Paludal stratigraphy of Truk, Ponape, and Kusaie, Eastern Caroline Islands. Geol Soc of America Bulletin, 81: 1895-1904.

Bloom, A. L., 1977. Atlas of Sea-Level Curves. International Geological Correlation Program 61, Cornell University, Ithaca, NY, USA.

Buddemeier, R., Smith, S., Kinzie, R., 1975. Holocene windward reef-flat history Enewetak atoll. Geol. Soc. Am. Bull. 86, 1581-1584.

Chappell, J., 1974. Late Quaternary glacio- and hydro-isostacy, on a layered earth. Quat. Res. Quaternary Research 4, 405-428.

Chappell, J., 1983. Evidence for smoothly falling sea level relative to north Queensland, Australia, during the past 6000yr. Nature 302, 406-408.

Chappell, J., 1987. Quaternary sea-level changes in the Australian region, in: Tooley, M.J., Shennan, I. (Eds.), Sea-level changes. Institute of British Geographers, London, . 296-331.

Chappell, J., Chivas, A., Wallensky, E., Polach, H., Aharon, P., 1983. Holocene palaeo-environmental changes central to north Great Barrier Reef inner zone. BMR Journal of Australian Geology and Geophysics 8, 223-235. 
Chappell, J., Rhodes, E.G., Thom, B.G., Wallensky, E., 1982. Hydro-isostacy and the sea-level isobase of 5500B.P. in North Queensland, Australia. Marine Geology 49, 81-90.

Clarke, J., Farrell, W., Peltier, W., 1978. Global changes in postglacial sea level: a numerical calculation. Quaternary Research 9, 265-287.

Curray, J. R., Shepard, F. P., Veeh, H. H., 1970. Late Quaternary Sea-level studies in Micronesia: CARMASEL expedition. Geol. Soc. Am. Bull. 81, 1865-1880.

Daly, R. A., 1920. A general sinking of sea-level in recent time. Proceedings of the National Academy of Sciences 6, 246-250.

Daly, R. A., 1925. Pleistocene changes of level. American Journal of Science 10, 281-313.

Darwin, C. R., 1842. The structure and distribution of coral reefs. Smith, Elder and Co., London.

David, T. W. E., Sweet, G., 1904. The geology of Funafuti., in: Society, T.R. (Ed.), The atol of Funafuti. The Royal Society, London, 66-124.

Davies, P. J., Hopley, D., 1983. Growth fabrics and growth rates of Holocene reefs in the Great Barrier Reef. BMR Journal of Australian Geology and Geophysics 8, 237-251.

Davies, P. J., Marshall, J.F., Hopley, D., 1985. Relationships between reef growth and sea level in the Great Barrier Reef. 5th International Coral Reef Congress 3, 95-103.

Dickinson, W. R., 2003. Impact of mid-holocene hydro-isostatic highstand in regional sea level on habitability of islands in Pacific Oceania. Journal Coastal Research 19, 489-502.

Druffel, E. R. M., and Griffin, S., 2004, Southern Great Barrier Reef Coral Radiocarbon DataI. IGBP PAGES/World Data Center for Paleoclimatology, Data Contribution Series \#2004-093, NOAA/NCDC Paleoclimatology Program: Boulder CO, USA.

Fairbridge, R.W., 1950. Recent and Pleistocene coral reefs of Australia. Journal of Geology 58, 330-401.

Fairbridge, R.W., 1961. Eustatic changes in sea level. Physics and Chemistry of Earth 4, 99-185.

Fairbridge, R.W., 1967. Coral reefs of the Australian region.In Jennings, J.N. and Mabbutt, J.A. (eds) Landform Studies from Australia and New Zeaaland, Canberra, Australian National University Press, 386-451.

Gill, E. D., 1961. Changes in the level of the sea relative to the land in Australia during the. Quaternary era. Zeitschrift fur Geomorphologie Supplementband 3, 73-79.

Gill, E. D., Hopley, D., 1972. Holocene sea levels in eastern Australia - a discussion. Marine Geology 12, 223-242.

Gillespie, R., Polach, H.A., 1979. The suitability of marine shells for radio-carbon dating of Australian pre-history, Proceedings of the Ninth International Conference on Radiocarbon Dating. University of California Press, University of California, pp. 404-421.

Hails, J. R., 1965. A critical review of sea-level changes in eastern Australia since the last glacial. Australian Geographical Studies 2, 63-78.

Harris, D. L., Webster, J. M., Vila-Concejo, A., Hua, Q., Yokoyama, Y., Reimer, P.J., 2015. Late Holocene sea-level fall and turn-off of reef flat carbonate production: Rethinking bucket fill and coral reef growth models. Geology 43, 175-178.

Haworth, R. J., Baker, R. G. V., Flood, P. G., 2002. Predicted and observed Holocene sea-levels on the Australian coast: what do they indicate about hydro-isostatic models in far-field sites? Journal of Quaternary Science 17, 581-591.

Hedley, C., 1925. The natural destruction of a coral reef. Reports to the Great Barrier Reef Committee 1, 35-40.

Hopley, D., 1971. Sea level and environment changes in the Late Pleistocene and Holocene in North Queensland, Australia. Quarternaria 14, 265-276.

Hopley, D., 1974. Investigations of sea-level changes along the coast of the Great Barrier Reef, Proceedings of the Second International Coral Reef Symposium, Great Barrier Reef, pp. $551-562$. 
Hopley, D., 1975. Contrasting evidence for Holocene sea levels with special reference to the BowenWhitsunday area of Queensland, in: Douglas, I., Hobbs, J.E., Pigram, J.J. (Eds.), Geographical essays in Honour of Gilbert J. Butland. Department of Geography, Uinversity of New England, Armidale, pp. 51-84.

Hopley, D., 1978. Sea level change on the Great Barrier Reef: an introduction. Philosophical Transactions of the Royal Society of London Series A 291, 159-166.

Hopley, D., 1980. Mid-Holocene high sea levels along the coastal plain of the Great Barrier Reef Province: a discussion. Marine Geology 35, M1-M9.

Hopley, D., 1982. Geomorphology of the Great Barrier Reef: Quaternary development of coral reefs. John Wiley-Interscience, New York.

Hopley, D., 1983. Morphological classification of shelf reefs: A critique with special reference to the Great Barrier Reef, in: Barnes, D.J. (Ed.), Perpectives on Coral Reefs. Brian Clouston, Canberra, pp. 180-199.

Hopley, D., 1984. The Holocene 'high energy window' on the central Great Barrier Reef, in: Thom, B.G. (Ed.), Coastal geomorphology in Australia. Academic Press, Canberra, pp. 135-150.

Hopley, D., Partain, B.R., 1987. The structure and development of fringing reefs of the Great Barrier Reef Province, in: Baldwin, C.L. (Ed.), Fringing Reef Workshop: Science, Industry and Management, 9 ed. Great Barrier Reef Marine Park Authority, Magnetic Island, pp. 13-33.

Hopley,D., Smithers, S.G., Parnell, K.P., 2007. Geomorphology of the Great Barrier Reef: Development, Diversity and Change. Cambridge University Press, Cambridge, UK, 546 pp.

Hopley, D., Thom, B.G., 1983. Australian sea levels in the last 15000 years: a review. Monograph Series, Geography Department, James Cook University Occasional Paper 3, 3-26.

Jelgersma, S., 1961. Holocene sea level changes in the Netherlands. Mededelingen Geologiische Stichtung, C6, 7, pp. 100.

Kench, P. S., Smithers, S. G., McLean, R. F., 2012. Rapid reef island formation and stability over an emerging reef flat: Bewick cay, northern Great Barrier Reef, Australia. Geology 40, 347350.

Kench, P. S., Smithers, S. G., McLean, R. F., Nichol, S. L., 2009. Holocene reef growth in the Maldives: Evidence of a mid-Holocene sea-level highstand in the central Indian Ocean. Geology 37, 455-458.

Kroon, F. J., Kuhnert, P. M., Henderson, B. L., Wilkinson, S. N., Kinsey-Henderson, A., Abbott, B., Brodie, J. E., Turner, R. D. R., 2012. River loads of suspended solids, nitrogen, phosphorus and herbicides delivered to the Great Barrier Reef lagoon. Marine Pollution Bulletin 65, 167-181.

Lambeck, K., 1993. Glacial rebound and sea-level change: and example of a relationship between mantle and surface processes. Tectonophysics 223, 15-37.

Lambeck, K., 2002. Sea-level change from mid-Holocene to recent time: an Australian example with global implications., in: Mitrovica, J.X., Vermeensen, L.L.A. (Eds.), Glacial Isostatic Adjustment and the Earth System. American Geophysical Union, Washington D.C., pp. 3350 .

Lambeck, K., Nakada, M., 1990. Late Pleistocene and Holocene sea-level change along the Australian coast. Paleogeogr. Paleoclimatol. Paleoecol. 89, 143-176.

Lambeck, K., Woodroffe, C. D., Antonioli, F., Anzidei, M., Gehrels, W. R., Laborel, J., Wright, A. J., 2010. Paleoenvironmental Records, Geophysical Modeling, and Reconstruction of Sea-Level Trends and Variability on Centennial and Longer Timescales, In J.A.Church, P.L.Woodworth, T. Aarup, W.S.Wilson (eds):Understanding Sea-Level Rise and Variability, Wiley Blackwell, pp. 61-121.

Larcombe, P., Carter, R. M., Dye, J., Gagan, M. K., Johnson, D. P., 1995. New evidence for episodic post-glacial sea-level rise, central Great Barrier Reef, Australia. Marine Geology 127, 1-44. 
Leonard, N. D., Welsh, K. J., Zhao, J. x., Nothdurft, L. D., Webb, G. E., Major, J., Feng, Y., Price, G. J., 2013. Mid-Holocene sea-level and coral reef demise: U-Th dating of subfossil corals in Moreton Bay, Australia. Holocene 23, 1841-1852.

Leonard, N. D., Zhao, J. X., Welsh, K. J., Feng, Y. X., Smithers, S. G., Pandolfi, J. M., Clark, T. R., 2016. Holocene sea level instability in the southern Great Barrier Reef, Australia: highprecision U-Th dating of fossil microatolls. Coral Reefs 35, 625-639.

Lewis, S. E., Sloss, C. R., Murray-Wallace, C. V., Woodroffe, C. D., Smithers, S. G., 2013. Post-glacial sea-level changes around the Australian margin: A review. Quaternary Science Reviews 74, $115-138$.

Lewis, S. E., Wüst, R. A. J., Webster, J. M., Collins, J., Wright, S. A., Jacobsen, G., 2015. Rapid relative sea-level fall along north-eastern Australia between 1200 and 800cal.yrB.P.: An appraisal of the oyster evidence. Marine Geology 370, 20-30.

Lewis, S. E., Wust, R. A. J., Webster, J. M., Shields, G. A., 2008. Mid-late Holocene sea-level variability in eastern Australia. Terra Nova 20, 74-81.

McLean, R. F., 1984. Coastal landforms: sea-level history and coastal evolution. Progress in Physical Geography 8, 429-442.

McLean, R. F., Stoddart, D. R., Hopley, D., Polach, H., 1978. Sea level change in the Holocene on the northern Great Barrier Reef. Philosophical Transactions of the Royal Society of London Series A 291, 167-186.

Morgan, K. M., Perry, C. T., Smithers, S. G., Johnson, J. A., Daniell, J.J., 2016. Evidence of extensive reef development and high coral cover in nearshore environments: Implications for understanding coral adaptation in turbid settings. Scientific Reports 6, 1-10.

Morgan, K. M., Perry, C. T., Smithers, S. G., Johnson, J. A., Gulliver, P., 2016. Transitions in coral reef accretion rates linked to intrinsic ecological shifts on turbid-zone nearshore reefs. Geology 44, 12, 995-998.

Murray-Wallace, C. V., Woodroffe, C. D., 2014. Quaternary Sea-Level Changes: A Global Perspective. Cambridge University Press, Cambridge, $484 \mathrm{pp}$.

Nakada, M., Lambeck, K., 1989. Late Pleistocene and Holocene sea-level change in the Australian region and mantle rheology. Geophysical Journal 96, 497-517.

Newell, N. D., Bloom, A. L., 1970. Te reef flat and 'two-metre eustatic terrace' of some Pacific atolls. Geol.Soc.America Bulletin, 81, 1881-1894.

Perry, C. T., Smithers, S. G., 2010. Evidence for the epiodic 'turn on' and 'turn off' of turbid zone coral reefs during the late Holocene sea-level highstand. Geology, 38, 119-122.

Perry, C. T., Smithers, S. G., 2011. Cycles of coral reef 'turn-on', rapid growth and 'turn-off' over the past 8,500 years: a context for understanding modern ecological states and trajectories. Global Change Biology 17, 76-86.

Pirazzoli, P., Montaggioni, L., 1988. The 7000 year sea level curve in French Polynesia: Geodynamic implications for mid plate volcanic islands., 6th International Coral Reef Symposium, Townsville, Australia, pp. 467-472.

Pirazzoli, P. A., Montaggioni, L. F., Salvat, B., Faure, G., 1988. Late Holocene sea level indicators from twelve atolls in the central and eastern Tuamotus. Coral Reefs 7, 57-68.

Rees, S. A., Opdyke, B. N., Wilson, P. A., Fifield, L. K., Levchenko, V., 2006. Holocene evolution of the granite based Lizard island and MacGillivray reef systems, Northern Great Barrier Reef. Coral Reefs 25, 555-565.

Ryan, E. J., Lewis, S. E., Smithers, S. G., Clark, T. R., Zhao, J. X., 2016. Multi-scale records of reef development and condition provide context for contemporary changes on inshore reefs. Global and Planetary Change 146, 162-148

Ryan, E. J., Smithers, S. G., Lewis, S. E., Clark, T. R., Zhao, J. X., 2016a. Chronostratigraphy of Bramston Reef reveals a long-term record of fringing reef growth under muddy conditions in 
the central Great Barrier Reef. Palaeogeography, Palaeoclimatology, Palaeoecology 441, 734-747.

Ryan, E. J., Smithers, S. G., Lewis, S. E., Clark, T. R., Zhao, J. X., 2016b. The influence of sea level and cyclones on Holocene reef flat development: Middle Island, central Great Barrier Reef. Coral Reefs 35, 805-818.

Schofield, J. C., 1970. Notes on late Quaternary sea levels, Fiji and Rarotonga. New Zealand Journal of Geology and Geophysics 13, 199-206.

Schofield, J. C., 1977. Late Holocene sea level, Gilbert and Ellice Islands, west central Pacific Ocean. New Zealand Journal of Geology and Geophysics 20, 503-529.

Scoffin, T., 1977. Sea-level features on reefs in the northern province of the Great Barrier Reef. 3rd International Coral Reef Symposium 2, 319-324.

Scoffin, T. P., Stoddart, D. R., 1978. The nature and significance of microatolls. Philosophical Transactions of the Royal Society of London Series B 284, 99-122.

Scoffin, T. P., Stoddart, D. R., McLean, R. F., Flood, P. G., 1978. The recent development of reefs in the Northern Province of the Great Barrier Reef. Philosophical Transactions of the Royal Society of London Series B 284, 129-139.

Shepard, F., Curray, J., Newman, W., Bloom, A., Newell, N., Tracey, J., Veeh, H., 1967. Holocene changes in sea level: Evidence in Micronesia. Science 157, 542-544.

Shepard, F. P., 1963. Thirty-five thousand years of sea level, in: Clements, T. (Ed.), Essays in marine geology in honour of K.O. Emery. Unversity of Southern California Press, Los Angeles, pp. $1-10$.

Sloss, C. R., Murray-Wallace, C. V., Jones, B. G., 2007. Holocene sea-level change on the southeast coast of Australia: a review. The Holocene 17, 999-1014.

Sloss, C. R., Westaway, K. E., Hua, Q., Murray-Wallace, C. V., 2013. An Introduction to Dating Techniques: A Guide for Geomorphologists, Treatise on Geomorphology, pp. 346-369.

Smithers, S. G., Hopley, D., Parnell, K. E., 2006. Fringing and nearshore coral reefs of the Great Barrier Reef: episodic Holocene development and future prospects. Journal of Coastal Research 22, 175-187.

Smithers, S. G., Woodroffe, C. D., 2000. Microatolls as sea-level indicators on a mid-ocean atoll. Marine Geology 168, 61-78.

Spender, M. A., 1930. Island reefs of the Queensland coast. Geographical Journal 76, 194-214, 273-293.

Stoddart, D. R., 1978. The Great Barrier Reef and the Great Barrier Reef Expedition 1973. Philosophical Transactions of the Royal Society of London Series A 291, 5-22.

Stoddart, D. R., McLean, R. F., Hopley, D., 1978a. Geomorphology of reef islands, northern Great Barrier Reef. Philosophical Transactions of the Royal Society of London Series B 284, 3961.

Stoddart, D. R., McLean, R. F., Scoffin, T. P., Thom, B. G., Hopley, D., 1978b. Evolution of reefs and islands, northern Great Barrier Reef: synthesis and interpretation. Philosophical Transactions of the Royal Society of London Series B 284, 149-159.

Stoddart, D. R., Scoffin, T.P.,1979. Microatolls: review of form, origin and terminology. Atoll Research Bulletin 224, 1-17.

Thom, B. G., Chappell, J., 1975. Holocene sea levels relative to Australia. Search 6, 90-93.

Thom, B. G., Chappell, J., 1978. Holocene sea level change: an interpretation. Philosophical Transactions of the Royal Society of London Series A 291, 187-194.

Thom, B. G., Hails, J. R., Martin, A. R. H., 1969. Radiocarbon evidence against higher postglacial sea levels in eastern Australia. Marine Geology 7, 161-168.

Thom, B. G., Hails, J. R., Martin, A. R. H., Phipps, C. V. G., 1972. Postglacial sea levels in eastern Australia-A reply. Marine Geology 12, 233-242. 
Tracey, J. I., Ladd, H. S., 1974. Quaternary history of Eniwetok and Bikini atolls, Marshall Islands., Proceedings of the Second International Coral Reef Symposium, Great Barrier Reef, pp. 537-550.

Walcott, R. I., 1972. Past sea levels, eustasy and deformation of the earth. Quaternary Research 2, 1-14.

Webb, G. E., Nothdurft, L. D., Zhao, J. X., Opdyke, B., Price, G., 2016. Significance of shallow core transects for reef models and sea-level curves, Heron Reef, Great Barrier Reef. International Association of Sedimentologists Special Publications.

Woodroffe, C., McLean, R., Polach, H., Wallensky, E., 1990. Sea level and coral atolls: Late Holocene emergence in the Indian Ocean. Geology 18, 62-66.

Woodroffe, C. D., McGregor, H. V., Lambeck, K., Smithers, S. G., Fink, D., 2012. Mid-Pacific microatolls record sea-level stability over the past $5000 \mathrm{yr}$. Geology 40, 951-954.

Woodroffe, C. D., McLean, R. F., 1990. Microatolls and recent sea level change on coral atolls. Nature 344, 531-534.

Woodroffe, S. A., 2009. Testing models of mid to late Holocene sea-level change, North Queensland, Australia. Quaternary Science Reviews 28, 2474-2488.

Yu, K. F., Zhao, J. X., 2010. U-series dates of Great Barrier Reef corals suggest at least $+0.7 \mathrm{~m}$ sea level $\sim 7000$ years ago. Holocene 20, 161-168. 



\title{
A GEOGRAPHICAL INVESTIGATION OF FACTORS AFFECTING THE NUMBER OF PLANTS ON NORTHERN AND SOUTHERN SAND CAYS OF THE GREAT BARRIER REEF, AUSTRALIA
}

\author{
SARAH M. HAMYLTON ${ }^{1}$
}

\begin{abstract}
Geography plays an important role in the distribution of plants on islands. This is in part because of the diversity of places and associated environmental conditions in which the islands are located, but also because of how islands are positioned with respect to one another. This relative positioning enters explicitly into island biogeographical character and can be expressed through spatial models. Over the past 20 years, spatial techniques for the empirical analysis of biological datasets have been increasingly applied to investigate biogeographical phenomena, particularly toward a better understanding of spatially structured underlying causative factors. These might include dispersal and competition, as well as environmental and historical influences. This study investigates patterns in the number of plant species occuring on 43 islands of the Great Barrier Reef (GBR) at three different geographical sectors (whole GBR, northern GBR, and southern GBR). Measures of spatial autocorrelation are calculated to explore the relationship between the diversity of plant populations on a given island and those on neighbouring islands. The relationship between the number of island plant species and local geographical context (latitude, longitude, distance from mainland, island area, island length, depth of surrounding GBR lagoon floor and island isolation) is investigated using three different regression models (ordinary least squares, spatially lagged and spatial error). Findings indicate that the southern islands exhibit the strongest spatial autocorrelation of plant species number between islands. In this sector, geographical context also explained the highest proportion of observed plant species numbers. The distribution of the number of plant species and their autocorrelation characteristics indicate metapopulation dynamics that could be a response to the variable sea-level history of these islands through the Holocene. This controls the time that plant communities have had to reach and maintain a dynamic equilibrium with their local environmental setting. Consistent higher performance of spatial as opposed to classic regression models highlighted the importance of interactions between plant communities on neighbouring islands, providing a persuasive case for explicitly building geography into studies of island plant communities.
\end{abstract}

\section{INTRODUCTION}

Geography plays an important role in the distribution of plants on islands. This fact was well known to David Stoddart, who spent much of his time on the Great Barrier Reef collecting and identifying plants to collate species lists by island, to enable a comparative analysis of their distribution. His efforts provide a foundation for the present study, which was inspired by a visit to David at his home in Oxford Street in April 2013. During that visit, David and I discussed plant biogeography on the Great Barrier Reef. Then he coaxed me down to his infamous basement, where he handed me his northern Great Barrier Reef plant species lists and uttered the words "we really ought to do something with these, can you help, Sarah?" This study combines those lists with records provided by Harold Heatwole for the southern Great Barrier Reef to investigate geographical factors affecting plants on the islands of the Great Barrier Reef.

\footnotetext{
${ }^{1}$ School of Earth and Environmental Sciences, University of Wollongong, Wollongong, Australia, New South Wales 2522. Email: shamylto@uow.edu.au
} 
The sand cays of the Great Barrier Reef (GBR) have formed through the build-up of carbonate materials (coral sand or shingle, molluscs, calcareous algae and foraminifera) over the last 4000 years (Hopley, 2008). Vegetation on these islands has played an important role in island evolution because root systems stabilise carbonate sedimentary deposits and thereby contribute to island structural integrity (Heatwole, 2011). From a biogeographical perspective, the plant populations on islands are the product of overwater dispersal, which itself is strongly shaped by the distance from neighbouring coastlines and differing sea level histories, which determine island age and associated availability of a platform for colonisation.

Mueller-Dombois and Fosberg (2013) consider the spatial distribution of island vegetation to be a function of six factors: geographical location (geology and geomorphology), climate (local and regional), disturbance, flora, access of plants or disseminules to a specific locality and the ecological functional role of plants making up a community. Geography plays an important role across each of these factors in two distinct ways. These can be explored empirically by treating island geographical locations as 'place' or as 'space', herein referred to as geographical place and geographical space. A treatment of island geographical place draws on the diversity of places in which the islands are found to vary the associated environmental conditions that drive their biogeographical character, thus emphasising the importance of place as context for plant species found on islands. The Great Barrier Reef stretches more than $2000 \mathrm{~km}$ from north to south, supporting a diverse array of over a thousand islands. Each of these islands is situated in a unique set of local environmental conditions characterised by a combination of exposure to incident waves, wash-over, storms, tidal range and cyclone frequency (Hamylton and Puotinen, 2015; Heatwole, 2011). In turn, these influence the compositional features of islands including their sedimentary characteristics and habitat diversity that also shape plant populations (Buckley, 1985). In a survey of 603 plant species, Heatwole (1991) used statistical regression to investigate the effects of geographical place on the plant communicates of both continental and cay islands on the Great Barrier Reef, finding a large proportion of the observed variation in the number of island plant species to be a function of island area and height.

An alternative view of geographical space emphasizes how islands are located with respect to one another, and how this relative positioning enters explicitly into their biogeographical character. Biological variability might arise from interactions between the islands that are a function of those spatial relationships. Such variability might be expressed through measurements such as distance, gradient and neighbourhood context. The identity of the plants on a given island depends on the composition of plant communities on neighbouring islands from which colonizing propagules may have travelled. Thus, the relationship between these two islands induces an effect in both locations that is not purely a consequence of the inherent properties of the two respective immediate locations. This is because the processes that influence island plant biogeography, including dispersal and plant species interactions, are also spatially structured. The tendency for organisms to disperse away from a site of origin is determined by the both structure of the environment and the method by which an organism disperses (Kinlan and Gaines, 2003). Plants such as mangroves shed their reproductive propagules at a relatively small size to disperse through a large and complex fluid environment (Stoddart, 1980). This provides potential for wide transport through a marine environment structured by ocean frontal systems and currents (Kinlan and Gaines, 2003), vertical stratification of the water column (Longhurst, 2010) and changes in substrate and bathymetry, particularly the presence of a suitable substrate for colonisation (i.e., the presence of a shallow island on a submerged shelf lagoon) (Gaines et al., 2007). Furthermore, once plants have colonised an island, they may aggregate because of resource availability, predator or competitor avoidance, mating behaviour, limited dispersal and advection, symbiosis, parasitism and disease in ways that give rise to spatial patterning (Robinson et al., 2011). The biological distribution of plants therefore emerges as a phenomenon driven by these two different conceptualisations of geographical place and space, which operate at a hierarchy of scales from the immediate neighbourhood up to regional scales along and across the reef shelf. It is therefore useful to explore the distribution of plants on islands using spatial techniques that draw explicitly on their position in the sense of both geographical place and space.

Spatial autocorrelation (known more broadly as spatial dependency) refers to the correlation of a single characteristic (e.g., plant species number) as a function of its position in geographic space 
(Hamylton, 2017). Positive spatial autocorrelation occurs when characteristics at proximate locations are more closely related than their distant counterparts, producing a clumped pattern (in contrast, negative autocorrelation can arise when characteristics close together are more unalike due to competition, producing a dispersed pattern). It is well known that plant communities of nearby islands tend to be similar because they are influenced by comparable spatially structured processes and neighbourhood interactions. But to what extent are these shaped by the distinct roles of geographical place and space? If a model is constructed to explain plant species number based on environmental correlates and the performance of that model improves with the incorporation of a spatial lag or error term that compares each island to its neighbouring islands, the implication is that neighbourhood interactions play an important role. Indeed, the extent to which the performance of the model changes with the incorporation of the spatial terms is indicative of the relative influence of geographical place and space. Allied developments in fields such as geographical information science have opened up the discipline of biogeography to the statistical exploration of population datasets through enquiry in which the location of information is explicitly incorporated (Haining, 2003).

This study investigates spatial patterns in the plant diversity of 43 islands (encompassing 613 species), across both the northern and southern sectors of the Great Barrier Reef. First, spatial autocorrelation is measured and interrogated for three geographic sectors (whole barrier reef, northern islands, southern islands) in order to explore spatial dependency between the diversity of plant populations on a given island and those on neighbouring islands. Second, for the same sectors, the relationship between the number of plant species supported by each island and the local geographical context (latitude, longitude, distance from mainland, island area, island length, depth of surrounding GBR lagoon floor and island isolation) is investigated using three different regression models (ordinary least squares, spatially lagged and spatial error). These models are compared to elucidate the relative influence of geographical place and space on the number of plant species supported by each island.

\section{MATERIALS AND METHODS}

\section{Study Sites}

The Great Barrier Reef (GBR) is the largest reef province in the world, containing over 1000 islands, including 350 coral cays (Hopley et al., 2007). Stretching over $15^{\circ}$ of latitude and with reef islands extending from the mainland to the shelf edge, the GBR spans a considerable diversity of local climatic conditions. Tropical cyclones form between November and April, with a pronounced late-summer peak when sea conditions are warmest (Harmelin-Vivien, 1994). The eastern boundary of the GBR intercepts swell waves generated across the Pacific Ocean and Coral Sea and islands are subject to smaller trade wind-generated waves within the GBR lagoon. Varying sea level histories along and across the continental shelf have resulted in a range of time windows over which islands have accumulated since the most recent post glacial transgression. Hydro-isostatic adjustment of the shelf to sea-level rise has meant that the sea attained its present level later at the outer reef (Lambeck et al., 2010) suggesting that the distance of an island from the mainland can be treated as a proxy for the time-range over which islands have developed. Accordingly, islands closer to the coastline may have had longer to accumulate (Hopley, 2008). Shallow drilling, U-series and radiocarbon dating evidence indicates that the underlying reef platforms grew on top of antecedent surfaces over the last 8000 years (Marshall and Davies, 1982, Woodroffe and Webster, 2014, Larcombe et al., 1995). It has been suggested that this was followed by a series of evolutionary sequences that lead to island formation through sediment infill into reef top depressions (see island evolutionary classification proposed by Hopley et al., 2007). Open water microatolls indicate a potential mid-Holocene sea-level oscillation of 1-1.5m above present sea level across the inner northern GBR suggesting a minor fall in sea level since then (Chappell, 1983). Subsequent researchers have inferred oscillations (for a review, see Lewis et al., 2013) and it is likely that significant variation in glacio- and hydro-isostatic adjustments across these regions has given rise to a geographically heterogeneous pattern 
of relative sea-level history. This has undoubtedly influenced the character of the islands that represent the end-point of these geomorphic transitional sequences.

Biogeographical work on the plants of the sand cays across the GBR can largely be classified as:

1. descriptive visual surveys and collections made with the aim of establishing distributions, regional schemes, boundaries and disjunctions;

2. studies applied to individual islands with the aim of characterising change within the context of biogeographical processes such as dispersal and drift or human influence; and,

3. larger scale studies that make phytogeographic observations across island groups, where possible drawing on regional empirical observations to infer reasonable explanations for patterns observed.

In relation to the first class, notable floristic collections include those made by Joseph Banks from the Endeavour, Robert Brown from Matthew Flinders' expedition on the Investigator, MacGillivray (1852), Steers (1938) and work in the southern islands summarised by (Chaloupka and Domm, 1985). Studies that fall into the second class have focussed on individual islands, particularly those southern islands easily accessible from the mainland that have been subject to more intense anthropogenic influence. From the Capricorn-Bunker group, these include Lady Elliot Island (Batianoff, 1998), Masthead Island (Batianoff, 1999), Heron Island (Smith and Heatwole, 1985), Wilson, Northwest, Hoskyn and Fairfax Islands (Cribb, 1965; Cribb, 1969; Cribb, 1972; Cribb, 1986). Regional studies that fall into the third class propose explanations of the distribution of the island flora of GBR and include the aforementioned modelling study by Heatwole (1991) and a comparative study by Stoddart and Fosberg (1991), who noted the marked difference between the floras of the southern and northern islands. The former were Indo-Pacific or pantropical in character and the latter were distinctively Australian, comprising a 'North Queensland element'. They proposed that the distinction between woodland flora of clear Australian affinity in the north and littoral flora of Indo-Pacific composition in the south reflected different dispersal mechanisms.

Table 1 summarises the broad classes of plant associations observed on sand cays of the GBR. Island vegetation types include tropical trees and shrubs, mangroves and seagrasses, which perform important ecosystem services such as sediment stabilisation, nutrient processing, shoreline protection, and provide habitat and nursery grounds (Duke and Larkum, 2008). On stable, older cays, mature soils, perhaps with guano deposits, have had time to form a climax woodland vegetation. For example, Pisonia grandis, often exists in association with phosphatic soils enriched by guano, although a highly dynamic environment may mean that all stages of a vegetational succession are present on a single island (Hopley et al., 2007). Commonly occurring plants span littoral and herbaceous species, shrubs, vines and trees, such as Pisonia grandis, Tournefortia argentia, Casuarina equisetifolia and Pandanus tectorius (Heatwole, 1987).

\section{Survey Data}

The islands of the Capricorn-Bunker group, including Lady Elliot, Lady Musgrave, Heron, One Tree Island and Fairfax were surveyed by the author during three fieldtrips in December 2012, June 2013 and May 2014. Additional plant survey data were provided for 15 southern and central islands of the present study by Harold Heatwole (Heatwole, 1991) and David Stoddart provided plant survey information for a further 28 islands that were mapped on the 1973 Royal Society and Universities of Queensland Expedition to the Northern Great Barrier Reef (Stoddart, 1978). Individual species lists are available from the Queensland Herbarium, Brisbane for the southern islands and have been published in the Atoll Research Bulletin for the northern islands (Fosberg and Stoddart, 1991). All surveys were undertaken during expeditions that were of a comparable length (three to four weeks), which permitted collections to be made for approximately one day per island, thus controlling for variations in collection effort. All species encountered were recorded in the survey plant lists, with the following inclusions and exclusions noted for introduced species (pers. comm): Lantana spp. (included), Cocos nucifera (included), Opuntia spp. (excluded). For the two islands that were re-surveyed by the author (Lady Musgrave and Heron Island) the early species lists were adopted for the analysis, as in both cases these were more extensive. 


\section{Measurement of Spatial Autocorrelation in Number of Plants Observed at Three Geographic Sectors}

Three areas of observation were defined for the purpose of this study. These were determined by the geographical scope of the field campaigns in which the plant surveys were undertaken and the observed difference between the floras of the northern and southern islands of the GBR (Stoddart and Fosberg, 1991). Each island was treated as a single data point of known location supporting a known number of plants. Firstly, an analysis of all islands surveyed was undertaken spanning the length of the entire Great Barrier Reef ( $n=43$; Figure 1). This region was then subdivided into a northern sector encompassing the islands surveyed on the expedition to the northern GBR, i.e., those north of Low Isles

Table 1. Common plant associations on sand cays of the Great Barrier Reef (summarised from Stoddart and Fosberg, 1991).

\begin{tabular}{|c|c|}
\hline Plant associations & Description \\
\hline $\begin{array}{l}\text { Initial plant colonisation on } \\
\text { sand cays }\end{array}$ & $\begin{array}{l}\text { Young communities of vascular plants, including coconut seedlings, } \\
\text { grasses and creepers. Often subject to disturbance, such as cyclone } \\
\text { damage or overtopping by swash at high tide. }\end{array}$ \\
\hline $\begin{array}{l}\text { Beach-crest scrub and } \\
\text { herbaceous vegetation with } \\
\text { trees }\end{array}$ & $\begin{array}{l}\text { Variable in composition, dependent on island size. Beach-crest } \\
\text { vegetation continuous cover of herbs and grasses, scattered shrubs } \\
\text { inland and scattered low trees }\end{array}$ \\
\hline $\begin{array}{l}\text { Scrub and succulent sward of } \\
\text { rock platforms }\end{array}$ & $\begin{array}{l}\text { Lithified windward rubble and shingle platforms that support low, } \\
\text { extensive monospecific scrub regularly submerged at high tide } \\
\text { (Aegialitis annulata or Avicennia marina), succulent mats on the } \\
\text { rock surface frequently wetted by spray, vegetative outposts on } \\
\text { inner, upper shingle ridges }\end{array}$ \\
\hline $\begin{array}{l}\text { Scrub and herbaceous cover of } \\
\text { windward shingle ramparts }\end{array}$ & $\begin{array}{l}\text { Ridged shingle ramparts inside conglomerate platforms with } \\
\text { vegetation becoming more continuous and dense on older, inner } \\
\text { ridges and merging into inland scrub }\end{array}$ \\
\hline $\begin{array}{l}\text { Pemphis scrub and scrub- } \\
\text { woodland }\end{array}$ & $\begin{array}{l}\text { Pemphis acidula (northern islands) in exposed situations on rocky } \\
\text { and thin shingle substrates, including on the seaward shores of sand } \\
\text { cays, on the inner margin of upper conglomerate windward platforms } \\
\text { and at the boundary of sand cay / mangrove swamps of low wooded } \\
\text { islands }\end{array}$ \\
\hline $\begin{array}{l}\text { Mixed scrub and herbaceous } \\
\text { vegetation }\end{array}$ & $\begin{array}{l}\text { An open mosaic of low shrubs, herbs, vines and grasses on sandy } \\
\text { substrates in the interiors of smaller, lower cays. }\end{array}$ \\
\hline Scrub woodland & As above, with less diverse ground cover and taller trees \\
\hline $\begin{array}{l}\text { Woodland of sand and sand- } \\
\text { shingle islands }\end{array}$ & $\begin{array}{l}\text { Dense, close canopy woodland found on larger islands. Dominated } \\
\text { by Pisonia in the southern islands, with interior phosphate rock. Also } \\
\text { support shrubs, but limited herbs and grasses due to canopy density }\end{array}$ \\
\hline Mangroves & $\begin{array}{l}\text { Mangroves are only present in the northern islands, with common } \\
\text { types defined as shrubs (Avicennia marina, Aegialitis annulata), } \\
\text { thicket (Ceriops, Osbornia) and woodland (Rhizophora mucronata } \\
\text { var. stylosa) }\end{array}$ \\
\hline Human-modified vegetation & $\begin{array}{l}\text { Anthropogenic grasslands, Agave thicket, removal of natural } \\
\text { woodland and scrub and introduction of exotic trees and decorative } \\
\text { plants / weeds. Selective encouragement of useful trees by } \\
\text { Aboriginal communities. }\end{array}$ \\
\hline
\end{tabular}


$(n=28)$, and a southern sector encompassing the Swains and the Capricorn -Bunker Group surveyed by Harold Heatwole, several of which were later re-surveyed by the author $(\mathrm{n}=15$, excluding two islands from the central reef) (Heatwole, 1987). To measure spatial dependency in the plant populations of the islands surveyed, spatial autocorrelation calculated as the univariate Moran's $I$ statistic for the number of plants observed at each island on the datasets corresponding to each spatial extent. The overall Moran's I metric indicated the strength of spatial autocorrelation across the island groups at each spatial extent, on a scale of -1 (negative spatial dependency) to +1 (positive spatial dependency). The significance of the resulting statistic was tested using a permutation approach in which a reference distribution was calculated 999 times for spatially random layouts with the same data values to construct a reference distribution

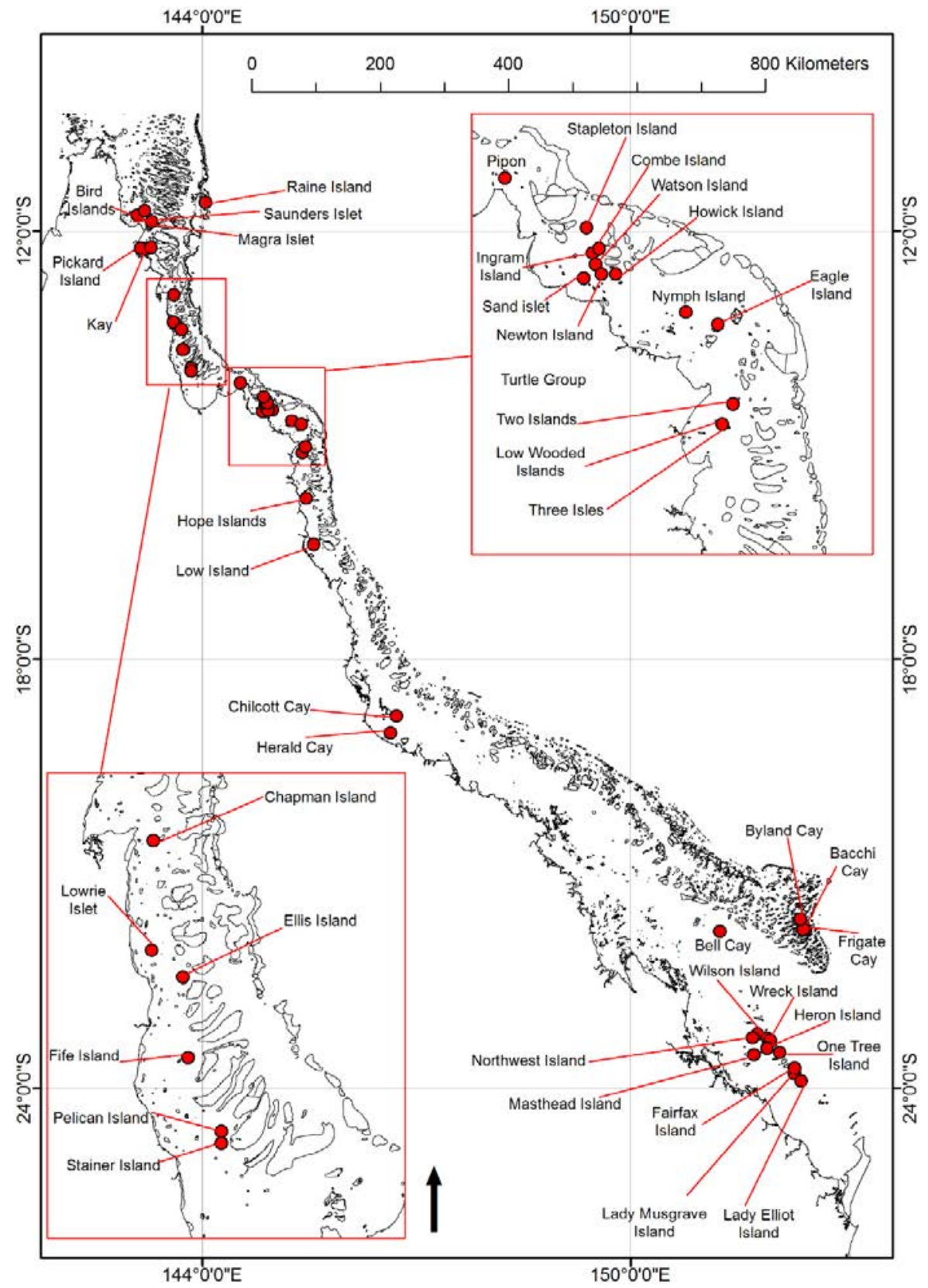

Figure 1. The 43 reef islands for which plant surveys were undertaken. 
against which the pseudo significance level is computed as the ratio of the number of statistics for the randomly generated datasets that are equal to or exceed the observed statistic to the number of permutations used (Anselin, 1996). To compute this statistic, a spatial weights file was constructed in which a threshold Euclidean distance of $6.11 \mathrm{~km}$ was defined, which was the minimum distance necessary for all islands to have at least one neighbour. Any islands falling inside this distance threshold were defined as a neighbour and assigned a weight of one within the spatial weights matrix.

Moran's I values were then presented in the form of a Moran scatter plot (Anselin, 1995). The scatter plot was constructed by plotting the number of plant species observed at each island against the spatially lagged weighted average of the variable (number of plant species observed) at neighbouring islands. Variables were normalised into standard deviations, such that graph quadrants corresponded to four types of spatial autocorrelation: high-high (upper right), low-low (lower left), for positive spatial autocorrelation, and high-low (lower right) and low-high (upper left), for negative spatial autocorrelation. Thus, the scatter plots indicated the presence of spatial dependency by virtue of the quadrants in which island data points fell, with points falling in the upper right and lower left quadrants indicating positive spatial autocorrelation, and points falling in the upper left and lower right quadrants indicating negative spatial autocorrelation.

\section{Assessing the Relationship Between the Number of Species of Plants Observed on Each Island and the Local Geographical Context}

Local geographical context was characterised through the following variables: latitude, longitude, distance from mainland, island area, island length, depth of surrounding GBR lagoon floor and island isolation (see Table 2).

Table 2. Variables employed to represent the biogeographical context of each island surveyed.

\begin{tabular}{|l|l|}
\hline $\begin{array}{l}\text { Biogeographical context variable } \\
\text { (range of values) }\end{array}$ & Description \\
\hline Latitude $\left(11.59^{\circ} \mathrm{S}\right.$ to $\left.24.11^{\circ} \mathrm{S}\right)$ & $\begin{array}{l}\text { y-coordinate of island centroid: A gradient of variation in } \\
\text { climate (rainfall, temperature), tidal range and cyclone } \\
\text { frequency }\end{array}$ \\
\hline Longitude $143.13^{\circ} \mathrm{E}$ to $152.45^{\circ} \mathrm{E}$ & $\begin{array}{l}\text {-coordinate of island centroid: A gradient of exposure to } \\
\text { oceanic swell }\end{array}$ \\
\hline Distance to mainland $4 \mathrm{~km}$ to $190 \mathrm{~km}$ & $\begin{array}{l}\text { Euclidean distance to Queensland coastline: A proxy for the } \\
\text { length of time available for islands to develop since the } \\
\text { postglacial marine transgression }\end{array}$ \\
\hline Island area $0.00045 \mathrm{~km}^{2}$ to $0.3 \mathrm{~km} 2$ & $\begin{array}{l}\text { Area of island / } \mathrm{km}^{2}: \text { An indicator of island structural } \\
\text { integrity, degree of washover, carrying capacity and } \\
\text { probability of plant colonisation through interception of } \\
\text { propagules }\end{array}$ \\
\hline $\begin{array}{l}\text { Island length } 0.2 \mathrm{~km} \text { to } 1 \mathrm{~km} \\
\text { Dength of longest island axis / } \mathrm{km} \text { : An indicator of island } \\
\text { structural integrity, degree of washover, carrying capacity } \\
\text { and probability of plant colonisation through interception of } \\
\text { propagules }\end{array}$ \\
\hline Island isolation & $\begin{array}{l}\text { Average depth of surrounding lagoon floor: A proxy for the } \\
\text { length of time available for islands to develop since the } \\
\text { postglacial marine transgression }\end{array}$ \\
\hline $\begin{array}{l}\text { Land area within } 6.11 \text { km radius of island" An indicator of } \\
\text { the potential for supply of propagules from neighbouring } \\
\text { land masses and their associated plant communities. }\end{array}$ \\
\hline
\end{tabular}


The depth of the surrounding GBR lagoon floor (excluding the reef platform) was chosen as an indication of the vertical distance that each reef would have had to grow to catch up with sea-level, which in turn indicates the length of time over which islands have been able to form. This value was determined by extracting the average value from a surrounding subset of a digital elevation model of the Great Barrier Reef (Beaman, 2010). Local statistics were computed by applying a buffer to each island centroid to define a circle of radius $2.11 \mathrm{~km}$ around each island, for which the digital elevation model was retained. This distance was the range defined by a semivariogram and corresponded to the distance beyond which the number of plant species no longer influenced each other due to spatial dependence (Hamylton, 2013). Within each buffer zone, a mask was applied to remove shallow values from reef platforms and the average of the bathymetric values associated with the remaining deeper GBR lagoon floor pixels from the digital elevation model in each zone was calculated for each island. The variable of island isolation was included to account for adjacent reservoirs of potential colonising plants (Stoddart and Fosberg, 1991). Island isolation was calculated as the amount of land falling within a distance of the aforementioned range of $6.11 \mathrm{~km}$ of each island. This was defined by creating buffer of $6.11 \mathrm{~km}$ around the vector dataset representing each island shoreline. The buffer dataset was then intersected with the overall islands dataset that represented bodies of emergent land across the broader GBR region.

Prior to the implementation of the regression models, variables were checked to ensure that the following assumptions of regression were met: adequate number of islands per independent variable, absence of outliers, linearity of association between the dependent and each independent variable, absence of multi-colinearity, normality, heteroscedasticity and constant variance of residuals and the independence of observations.

Three different regression models were developed using the open source software GeoDa. These assessed the relationship of the observed number of species of plants on each island to the local geographical context: ordinary least squares, spatially lagged and spatial error (Hamylton, 2017). These were applied to a range of geographical areas, including across the entire GBR $(n=45)$, within the northern islands $(n=28)$ and within the southern islands $(n=13)$. The second and third models introduced a spatially explicit term to the regression equation that either took the form of a spatially lagged dependent variable (sometimes referred to as an 'autoregressive' term), or a modelled estimate of the spatial error. This explicitly accounted for the relative location of each island by taking information from neighbouring islands into account. Where positive spatial autocorrelation is present, the development of non-spatial models of plant species numbers across the islands increases the likelihood of a Type I error through artificial inflation of goodness of fit measures because some of the effect due to spatial interaction would have been allocated to the existing covariates. By developing models with a spatially dependent structure, such as the spatial lag model or spatial error model, this can be addressed through re-specification to incorporate a neighbourhood context effect operating through the response variable itself. In the case of a spatial lag model, if the dependent variable is the number of plant species on the islands, the spatially lagged term represented the average number of plant species calculated for all neighbouring islands falling within a distance of $6.11 \mathrm{~km}$ (i.e. the spatial lag) from the island for which the number of plants was to be modelled. In the case of the spatially lagged response variable, this is akin to stating that the number of plant species surveyed at a given island might itself be a function of those surveyed at neighbouring islands. The spatial error model took an alternative approach that subdivided the error term arising from a standard OLS regression model into spatially structured unexplained and unexplained components. The former component was then modelled by incorporating the error at a neighbouring location as a regression variable, thereby enabling it to be accounted for without the cause necessarily being known.

All three regression models explored the effects of geographical place on the number of island plant species by empirically exploring their relationship to a range of geographical context variables. The two spatial regressions further accounted for information from neighbouring islands. This did not require information on any additional covariates, rather, they utilised the location information of each island to construct a geographically weighted term to express the number of plant species as a function of their relative position. 


\section{RESULTS}

Figure 2 illustrates the univariate Moran scatter plot of spatial autocorrelation for each of the three spatial extents studied. Most island data points fell within the lower left and upper right quadrants, indicating positive spatial autocorrelation. This was corroborated by Moran's I statistics of moderate strength at two of the spatial extents corresponding to all islands and in the northern sector (Moran's I of 0.48 and 0.35 respectively), and of higher strength between the southern islands (Moran's I of 0.71 ).

Spatial models consistently performed better at explaining variation in the number of plant species observed on each island than the ordinary least squares model at every geographical extent of application (Table 3).

Table 3. Diagnostics of the three different types of regression of the relationship between the number of plant species and local biogeographical context of each sand cay. Values in brackets indicate z-scores for ordinary least squares models and t-statistics for spatial models.

\begin{tabular}{|c|c|c|c|c|c|c|c|c|}
\hline \multicolumn{9}{|c|}{ Variables: $\boldsymbol{\beta}$ coefficient ( $\mathrm{z}$-score or $\mathrm{t}$-statistic) } \\
\hline & Lat & Long & $\begin{array}{l}\text { Distance } \\
\text { to main- } \\
\text { land }\end{array}$ & $\begin{array}{l}\text { Island } \\
\text { Area }\end{array}$ & $\begin{array}{l}\text { Island } \\
\text { length }\end{array}$ & $\begin{array}{l}\text { Lagoon } \\
\text { depth }\end{array}$ & $\begin{array}{l}\text { Island } \\
\text { isolation }\end{array}$ & $\begin{array}{l}R^{2} \\
\text { (p-value) }\end{array}$ \\
\hline \multicolumn{9}{|c|}{ All islands $(n=45)$} \\
\hline $\begin{array}{l}\text { Ordinary least } \\
\text { squares }\end{array}$ & $\begin{array}{l}-2.04 \\
(-2.91)\end{array}$ & $\begin{array}{l}-0.12 \\
(-1.33)\end{array}$ & \begin{tabular}{|l}
-17.50 \\
$(-4.20)$
\end{tabular} & \begin{tabular}{|l|}
-5.83 \\
$(-1.50)$
\end{tabular} & $\begin{array}{l}51.28 \\
(0.90)\end{array}$ & $\begin{array}{l}0.32 \\
(1.93)\end{array}$ & $\begin{array}{l}50.45 \\
(3.78)\end{array}$ & $\begin{array}{l}0.41 \\
(p<0.02)\end{array}$ \\
\hline Spatially lagged & $\begin{array}{l}-1.32 \\
(-1.98) \\
\end{array}$ & $\begin{array}{l}-0.07 \\
(-0.91) \\
\end{array}$ & $\begin{array}{l}-12.16 \\
(-2.70) \\
\end{array}$ & \begin{tabular}{|l}
-4.77 \\
$(-1.39)$ \\
\end{tabular} & $\begin{array}{l}51.92 \\
(1.03) \\
\end{array}$ & $\begin{array}{l}0.20 \\
(1.30)\end{array}$ & $\begin{array}{l}41.54 \\
(2.31) \\
\end{array}$ & $\begin{array}{l}0.51 \\
(p<0.03)\end{array}$ \\
\hline Spatial error & $\begin{array}{l}-1.62 \\
(-2.04) \\
\end{array}$ & $\begin{array}{l}-0.08 \\
(-0.75) \\
\end{array}$ & $\begin{array}{l}-16.72 \\
(-3.41) \\
\end{array}$ & \begin{tabular}{|l|}
-4.49 \\
$(-1.31)$ \\
\end{tabular} & $\begin{array}{l}52.16 \\
(1.06)\end{array}$ & $\begin{array}{l}0.18 \\
(1.06) \\
\end{array}$ & $\begin{array}{l}53.25 \\
(3.12)\end{array}$ & $\begin{array}{l}0.64 \\
(p<0.01)\end{array}$ \\
\hline \multicolumn{9}{|c|}{\begin{tabular}{|l|} 
Northern islands $(n=28)$ \\
\end{tabular}} \\
\hline $\begin{array}{l}\text { Ordinary least } \\
\text { squares }\end{array}$ & $\begin{array}{l}2.98 \\
(1.01)\end{array}$ & $\begin{array}{l}15.39 \\
(3.57)\end{array}$ & \begin{tabular}{|l}
-15.51 \\
$(-1.14)$
\end{tabular} & $\begin{array}{l}-120 \\
(-0.34)\end{array}$ & $\begin{array}{l}88.68 \\
(1.52)\end{array}$ & $\begin{array}{l}-0.44 \\
(-1.67)\end{array}$ & $\begin{array}{l}78.28 \\
(4.02)\end{array}$ & $\begin{array}{l}0.56 \\
(p<0.01)\end{array}$ \\
\hline Spatially lagged & $\begin{array}{l}0.62 \\
(0.23)\end{array}$ & $\begin{array}{l}16.09 \\
(4.16)\end{array}$ & $\begin{array}{l}-11.77 \\
(-1.03)\end{array}$ & $\begin{array}{l}-107 \\
(-0.36)\end{array}$ & $\begin{array}{l}82.85 \\
(1.70)\end{array}$ & $\begin{array}{l}-0.42 \\
(-1.94)\end{array}$ & $\begin{array}{l}83.45 \\
(5.90)\end{array}$ & $\begin{array}{l}0.66 \\
(p<0.02)\end{array}$ \\
\hline Spatial error & $\begin{array}{l}3.18 \\
(1.22) \\
\end{array}$ & $\begin{array}{l}15.72 \\
(4.15)\end{array}$ & \begin{tabular}{|l|}
-15.88 \\
$(-1.35)$ \\
\end{tabular} & $\begin{array}{l}-117.54 \\
(-0.38) \\
\end{array}$ & $\begin{array}{l}88.76 \\
(1.76)\end{array}$ & $\begin{array}{l}-0.44 \\
(1.00)\end{array}$ & $\begin{array}{l}85.26 \\
(4.81)\end{array}$ & $\begin{array}{l}0.65 \\
(\mathrm{p}<0.02)\end{array}$ \\
\hline \multicolumn{9}{|c|}{ Southern islands $(n=17)$} \\
\hline $\begin{array}{l}\text { Ordinary least } \\
\text { squares }\end{array}$ & $\begin{array}{l}-11.44 \\
(-1.02)\end{array}$ & $\begin{array}{l}-8.77 \\
(-0.6)\end{array}$ & $\begin{array}{l}4.35 \\
(0.2)\end{array}$ & \begin{tabular}{|l}
143776 \\
$(4.41)$
\end{tabular} & \begin{tabular}{|l|}
-60.21 \\
$(-1.40)$
\end{tabular} & $\begin{array}{l}0.1 \\
(0.46)\end{array}$ & $\begin{array}{l}89.18 \\
(3.22)\end{array}$ & $\begin{array}{l}0.84 \\
(p<0.09)\end{array}$ \\
\hline Spatially lagged & $\begin{array}{l}-12.93 \\
(-1.60) \\
\end{array}$ & $\begin{array}{l}-9.59 \\
(1.04) \\
\end{array}$ & $\begin{array}{l}3.03 \\
(0.20) \\
\end{array}$ & $\begin{array}{l}130004 \\
(5.30)\end{array}$ & $\begin{array}{l}-50.42 \\
(-1.71) \\
\end{array}$ & $\begin{array}{l}0.14 \\
(1.00)\end{array}$ & $\begin{array}{l}87.35 \\
(4.60) \\
\end{array}$ & $\begin{array}{l}0.94 \\
(p<0.01)\end{array}$ \\
\hline Spatial error & $\begin{array}{l}-2.31 \\
(-0.55)\end{array}$ & $\begin{array}{l}1.81 \\
(0.40)\end{array}$ & $\begin{array}{l}-13.51 \\
(-1.60)\end{array}$ & $\begin{array}{l}14859 \\
(9.75)\end{array}$ & $\begin{array}{l}-21.87 \\
(-1.19)\end{array}$ & $\begin{array}{l}0.26 \\
(2.65)\end{array}$ & $\begin{array}{l}89.21 \\
(4.92)\end{array}$ & $\begin{array}{l}0.97 \\
(p<0.01)\end{array}$ \\
\hline
\end{tabular}

Of the independent variables employed, there was a notable consistency in relative contribution to explaining the observed variation in the number of plant species recorded. For the models applied to all islands, distance to mainland was the strongest predictor of the number of plant species, while in the northern sector, longitude was consistently the strongest predictor and in the southern sector, island area was consistently the strongest predictor. 

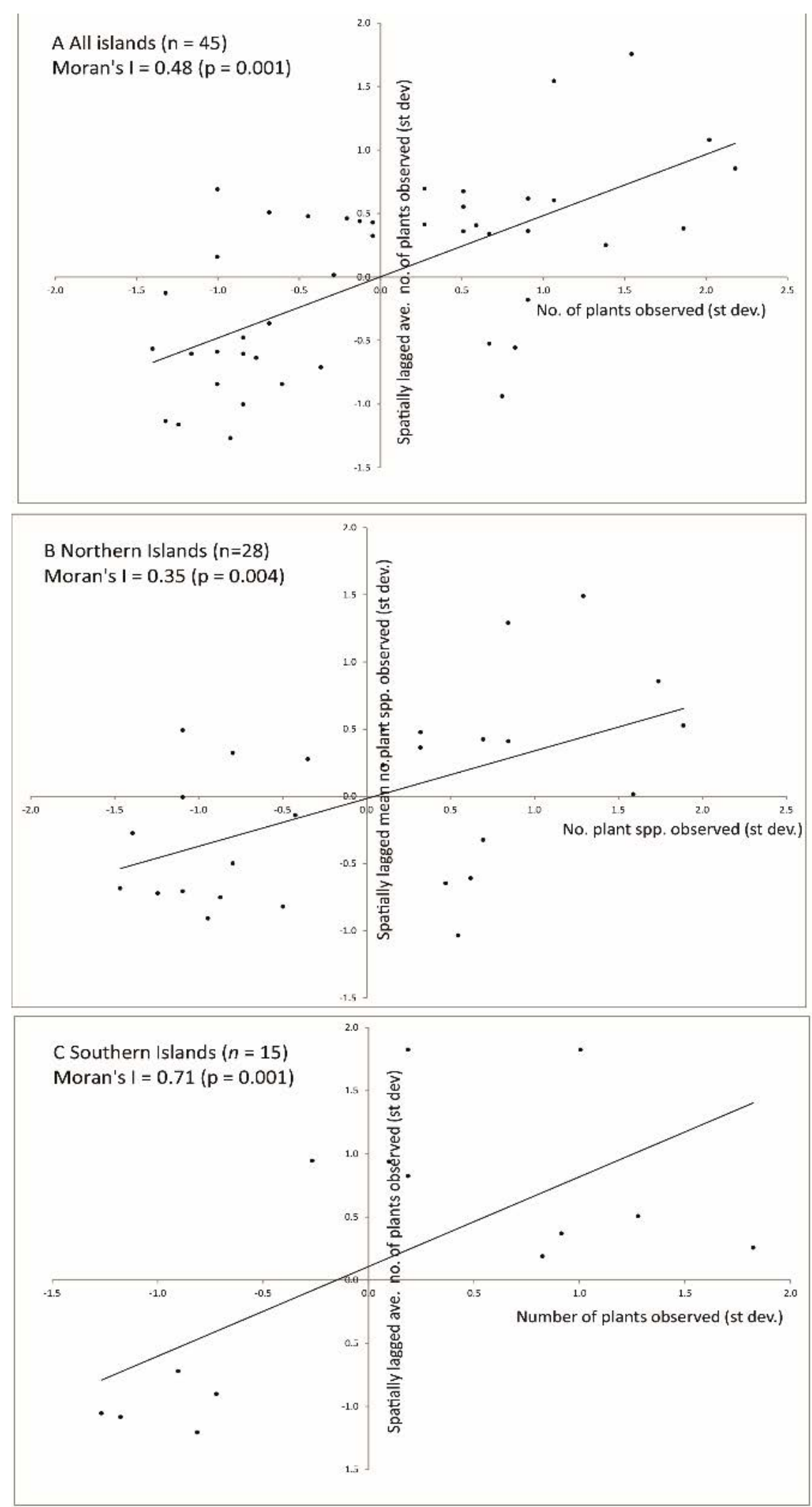

Figure 2. Univariate Moran scatter plot of spatial autocorrelation for A. All 43 islands along the Great Barrier Reef, B. Northern islands, and C. Southern islands. 


\section{DISCUSSION AND CONCLUSIONS}

The higher levels of autocorrelation observed in the southern islands relative to the northern islands, alongside the consistent better performance of the regression models here, may relate to the historical development of the islands. More plant species are supported by the islands in the north than those in the south (an average of 22 species per island in the northern sector, as opposed to 15 in the southern sector). This is driven in part by a much greater degree of endemism in the northern islands, with 330 species known only north of Cairns $\left(16^{\circ} 45^{\prime} \mathrm{S}\right)$, compared to 33 known only to the Capricorn-Bunker Islands (Stoddart and Fosberg, 1991). Such a remarkable disparity means that the greater range of species in the north affords a greater opportunity for variation in plant species number supported by the northern islands, thereby reducing their potential for autocorrelation. One notable environmental difference between the northern and southern islands is the depth of the surrounding GBR lagoon floor, which is much deeper in the southern (ranging from -29 to $-70 \mathrm{~m}$ ) than the northern sector $(-7$ to $-28 \mathrm{~m})$. The varying sea level histories, both along and across the continental shelf, mean that the position of an island will determine the time-range over which it has accumulated (Hopley et al., 2007). All of the sampled reef islands reached sea level and infilled their lagoons and reef flats over the Holocene, although those in the south likely experienced a temporal lag corresponding to the additional time taken to reach sea level from a deeper antecedent lagoon shelf.

Radiocarbon dating of interior island sediments has suggested that deposition at the southernmost island (Lady Elliot) began around 3200 years ago (Chivas et al., 1986) whilst sediments from the northern cay (Bewick) indicate island building there began earlier, 5000-4000 yr BP (Kench et al., 2012). There are also several notable islands in the northern sector (e.g., Two Isles, Three Isles, East Hope) that have high terraces reaching around $5 \mathrm{~m}$ above current sea level (McLean et al., 1978; Stoddart et al., 1978). It is therefore possible that older islands in the north may be less autocorrelated because they have had a longer time to reach a dynamic equilibrium with their local environments. Stoddart and Fosberg (1991) distinguish between older, higher sand cays in the approximate age range of 2900-3400 yr BP that support closed canopy woodland and younger, lower terraces of average age 2700 years that support low shrubs, herbs, vines and grasses.

There also remains the possibility that flora of the larger forested islands is relict from the last glacial period (ca. 8000 years BP), when the modern reefs were superimposed on the dry northern coastal shelf (Stoddart and Fosberg, 1991). Thus, the statistically discernible spatial patterns of the plant communities might express variable sea level history and associated island age along the latitudinal extent of the GBR (McLean et al., 1978). To further perpetuate this distinction, Buckley (1981) notes the likelihood of a slower response rate to environmental changes of the northern 'forest-tree' islands relative to the southern 'strandline' islands. Despite the widespread supply of propagules by fruit eating birds or human visits across all the islands studied, these may give rise to variable timescales over which metapopulation dynamics and dynamic equilibria may emerge between mean plant species richness and local environmental conditions.

Unique features of islands that lend themselves well to the statistical analysis of populations include their relatively isolated geographical setting and ease with which boundary conditions can be specified (Whittaker and Fernández-Palacios, 2007). Islands also have minimal resident human populations and few impacts from economic development and resource extraction, making them particularly attractive case studies (Sanmartín et al., 2010). Several regional (i.e., island-group) scale studies have sought to explain the distribution of plant diversity in relation to potential causal factors in the British Isles (Johnson and Simberloff, 1974), the Galápagos islands (Connor and Simberloff, 1978), Nui Atoll in the Pacific (Woodroffe, 1986), Hawaiian Islands (Price, 2004) and British Columbia (Cody, 2006). These studies have considered how geographical place and e associated local environmental context influences islands and the plants they support. Such considerations empirically investigate the relationship between regional biophysical conditions and plant communities. Characterisation of this relationship is attractive because it allows prediction of longer-term island vegetation community response to future anticipated conditions. Such predictions are useful for environmental management decisionmaking and extend the traditional scope of biogeographical work from mapping distributions and 
explaining associated patterns to the development of theoretical and deterministic propositions about how the vegetation of low lying islands responds to environmental conditions (Graves and Reavey, 1996). As part of this approach, spatial models offer a unique opportunity to incorporate terms that reflect interaction between sites, accounting for geographical space. In this case, the marked and consistent growth in explanatory power of the spatial models that incorporated island neighbourhoods implied that these interactions have an important role. These have not been explicitly incorporated in previous statistical investigations of plant species numbers across the sand cays of the Great Barrier Reef.

In the context of island biogeography, neighbourhood effects are largely driven by modes of dispersal. For example, Pisonia grandis fruits become attached to birds such as the Black Noddy and Bridled Tern through a sticky resinous residue and are subsequently transported over water (Chen and Krol, 2004). The Indo-Pacific character of the southern island plant communities indicates dispersal across the GBR from this region. Drift disseminules of 34 plant species that were collected on the cays of the Swains Reefs suggest inward flow from the New Caledonia-Vanuatu-Fiji region, facilitated by the East Australia current (Smith et al., 1990). Similar studies have noted the viability of drift seeds and fruit on Raine Island in the northern GBR originating from either northern Australia or Papua New Guinea (Hacker, 1990).

Because of the paucity of herbaceous plant species in the fossil record, support for the longerterm continental influence on woody plant species composition in the northern sector has been through phytogeographic observations. For example, the common woodland tree species in the north (including Aglaia elaeagnoidea, Diospyros maritima, Eugenia carrisoides, Exocarpos latifolia, Ficus opposita, Manilkara kauki, Mimusops elengi, Pouteria obovata, Terminalia arenicola, and Terminalia muelleri) align much more closely to those associated with northern continental Queensland than the southern islands, whereas both Pisonia and Pandanus, which occur on the southern sand cays, are uncommon in the north (Stoddart and Fosberg, 1991). The rate of extinction of existing species is likely to be heavily influenced by episodic disturbance events, such as storms, cyclones and associated mechanical damage driving large scale species turnover (Flood and Heatwole, 1986), but also through chronic disturbances such as saltwater intrusion into the freshwater lens upon which many plant species are fundamentally reliant (White and Falkland, 2010). Neighbourhood influences in immigration and extinctions may also arise through spatially-structured environmental processes, such as regional variation in rainfall. Mean annual rainfall in the northern islands, such as Green Island $(2152 \mathrm{~mm})$ and Low Isles $(2027 \mathrm{~mm})$ is substantially greater than that recorded for Heron Island further south $(965 \mathrm{~mm})$, such variability might be due to a combination of the mountainous Queensland coastline, southeast trade winds and the intertropical convergence zone.

Neighbourhood effects were stronger among the islands of the southern sector, where regressions of island plant species against variables depicting the geographical context also consistently performed better relative to those applied to both the northern islands and the entire GBR datasets. For the southern sector, island area emerged as the strongest predictor of plant species number, in accordance with conventional island biogeography theory and earlier findings on the primary importance of island area (Heatwole, 1991; Whitehead and Jones, 1969). Island area might be important because of the enhanced probability that larger islands will be reached by dispersing propagules (Buckley and Knedlhans, 1986), or the greater habitat diversity and associated range of ecological niches on larger islands, resulting in reduced competition for resource utilisation (Tilman et al., 1997). Variation in edaphic factors, including surface phosphatisation, the relative proportion of sand and shingle; the presence or absence of groundnesting sea-birds and human interference are also likely related to island size. Substrate gradients from beach to interior are also particularly marked on larger reef islands and likely translate to a greater range of vegetative expression (Heatwole, 1991).

The spatial models presented here may be improved by the use of anisotropic methods that account for the associated directional dependence of marine environmental processes, such as ocean currents that may drive the dispersal of plant seed propagules and the ability of islands to intercept these (Buckley and Knedlhans, 1986). It may also be useful to control for the fact that many of the cays of the Great Barrier Reef have been significantly modified by human activities, including the removal of guano and rock phosphate, military bombing and shelling, plantation of coconut palms, the introduction of goats 116 
and exotic plant species (e.g. Lantana spp. and prickly pear, Opuntia spp) and the development of infrastructure such as tourist resorts and airstrips (Daley, 2014). From an ecological perspective, it may be instructive to include the diversity of common plant associations (Table 1) in the regression model as an indicator of functional groupings, particularly those occurring in different stages of island vegetative succession (Heatwole, 2011), alongside the potential for competition to occur. Nevertheless, in a world increasingly worried about the effects of human activity, such spatially-explicit empirical linkages between plant numbers on reef islands and their biogeographical surroundings allow predictions as to how future plant communities might change for a range of environmental circumstances.

\section{ACKNOWLEDGEMENTS}

This research was supported by a University of Wollongong Return to Work Grant. I am much indebted to our boat skipper, Russell Graham, for practical assistance with reaching the islands surveyed. This analysis would not have been possible without the plant survey datasets that were kindly provided by Professor David Stoddart (University of California, Berkeley) and Professor Harold Heatwole (North Carolina State University). This work has been energised and informed through lively discussions with both David and Harold. While this manuscript was in preparation, I learned the sad news of David's passing and I wish in particular to acknowledge his inspirational work on reef island geography.

\section{REFERENCES}

Anselin, L. 1995. Local indicators of spatial association-LISA. Geographical Analysis, 27, 93-115.

Anselin, L. 1996. The Moran scatterplot as an ESDA tool to assess local instability in spatial association. In: Spatial AnalyticalPerspectives on GIS, M.Fischer, H.J. Scholten and D. Unwin (Eds), Taylor and Francis, UK, 111-125.

Batianoff, G. 1998. Coral cay terrestrial flora changes at Lady Elliot Island, Great Barrier Reef, Australia. Proceedings of the Royal Society of Queensland, 107. 5-14.

Batianoff, G. N. 1999. Floristic, vegetation and shoreline changes on Masthead Island, Great Barrier Reef, Australia.. Proceedings of the Royal Society of Queensland, 108, 1-11.

Beaman, R. 2010. Project 3DGBR: A high-resolution depth model for the Great Barrier Reef and Coral Sea. Marine and Tropical Sciences Research Facility (MTSRF) Project 2.5 i. I a Final Report, Reef and Rainforest Research Centre, Cairns, Australia, 13 pp. plus Appendix 1.

Buckley, R. 1981. Scale-dependent equilibrium in highly heterogeneous islands: plant geography of the northern Great Barrier Reef sand cays and shingle islets. Australian Journal of Ecology, 6, 143 47.

Buckley, R. 1985. Distinguishing the effects of area and habitat type on island plant species richness by separating floristic elements and substrate types and controlling for island isolation. Journal of Biogeography, 12, 527-535.

Buckley, R. and Knedlhans, S. 1986. Beachcomber biogeography: interception of dispersing propagules by islands. Journal of Biogeography, 13, 69-70.

Chaloupka, M. and Domm, S. 1985.Comprehensive regional survey of the terrestrial flora on coral cays in the Capricornia Section of the Great Barrier Reef Marine Park. Proceedings of the Royal Society of Queensland, 96. 75-80.

Chappell, J. 1983. Evidence for smoothly falling sea level relative to north Queensland, Australia, during the past 6,000 yr. Nature, 302, 406-408.

Chen, D. and Krol, A. 2004. Hydrogeology of Heron Island, Great Barrier Reef, Australia. Developments in Sedimentology, 54, 867-884.

Chivas, A., Chappell, J., Polach, H. Pillans, B. and Flood, P. 1986. Radiocarbon evidence for the timing and rate of island development, beach-rock formation and phosphatization at Lady Elliot Island, Queensland, Australia. Marine Geology, 69, 273-287. 
Cody, M. L. 2006. Plants on Islands: Diversity and Dynamics on a Continental Archipelago, University of California Press, 269 pp.

Connor, E. F. and Simberloff, D. 1978. Species number and compositional similarity of the Galapagos flora and avifauna. Ecological Monographs, 48, 219-248.

Cribb, A. 1965. The marine and terrestrial vegetation of Wilson Island, Great Barrier Reef. Proceedings of the Royal Society of Queensland, 77, 53-66.

Cribb, A. 1969. The vegetation of North West Island. Queensland Naturalist, 19, 85-93.

Cribb, A. 1972. Vegetation of Hoskyn Island and reef. Queensland Naturalist, 20, 92-100.

Cribb, A. 1979. The terrestrial vegetation of Fairfax Islands, Great Barrier Reef. Queensland Naturalist, 43, 119-126.

Daley, B. 2014. The Great Barrier Reef: An Environmental History, Routledge, Oxford, UK, 254 pp.

Duke, N. and Larkum, A. 2008. Mangroves and seagrasses. In: The Great Barrier Reef Biology, Environment and Management, P. Hutchings, M. Kingsford, O Hoegh-Guldberg (Eds), CSIRO Publishung, Collingwood, Vic, Australia, 156-170.

Flood, P. G. and Heatwole, H. 1986. Coral cay instability and species-turnover of plants at Swain Reefs, Southern Great Barrier Reef, Australia. Journal of Coastal Research, 2, 4, 479-496.

Fosberg, F. R. and Stoddart, D. R. 1991. Plants of the reef islands of the northern Great Barrier Reef. Atoll Research Bulletin, 348, 1-82.

Gaines, S., Gaylord, B., Gerber, L., Hastings, A. and Kinlan, B. 2007. Connecting places: The ecological consequences of dispersal in the sea. Oceanography, 20, 3, 90-99.

Graves, J. and Reavey, D. 1996. Global Environmental Change: Plants, Animals and Communities. Longman, Harlow, England, 226 pp.

Hacker, J. 1990. Drift seeds and fruit on Raine Island, northern Great Barrier Reef, Australia. Journal of Biogeography, 17, 19-24.

Haining, R. P. 2003. Spatial Data Analysis, Cambridge University Press, Cambridge, UK.

Hamylton, S. M. 2013. Five practical uses of spatial autocorrelation for studies of coral reef ecology. Marine Ecology Progress Series, 478, 15-25.

Hamylton, S. M. and Puotinen, M. 2015. A meta-analysis of reef island response to environmental change on the Great Barrier Reef. Earth Surface Processes and Landforms, 440, 8, 1006-1016.

Hamylton, S. M. 2017. Spatial Analysis of Coastal Environments, Cambridge University Press, Cambridge, UK.

Harmelin-Vivien, M. L. 1994. The effects of storms and cyclones on coral reefs: a review. Journal of Coastal Research, 12, 211-231.

Heatwole, H. 1991. Factors affecting the number of species of plants on islands of the Great Barrier Reef, Australia. Journal of Biogeography 18, 2, 213-221.

Heatwole, H. 2011. Coral cays, vegetational succession. In: Encyclopedia of Modern Coral Reefs, Hopley, D, (Ed) Springer, Netherlands, 256-261.

Heatwole, H. F. 1987. Some Aspects of Phytogeography and Vegetation Dynamics of Islands of the Great Barrier Reef. PhD thesis, School of Biological Sciences, The University of Queensland, $367 \mathrm{pp}$.

Hopley, D. 2008. Geomorphology of coral reefs with special reference to the Great Barrier Reef. In: The Great Barrier Reef Biology, Environment and Management, P. Hutchings, M. Kingsford, O. Hoegh-Guldberg (Eds), CSIRO Publishung, Collingwood, Vic, Australia, 5-16.

Hopley, D. Smithers, S. G. and Parnell, K. 2007. The Geomorphology of the Great Barrier Reef: Development, Diversity and Change, Cambridge University Press, Cambridge, UK.

Johnson, M. P. and Simberloff, D. S. 1974. Environmental determinants of island species numbers in the British Isles. Journal of Biogeography, 1, 3, 149-154.

Kench, P.S. Smithers, S.G. and McLean, R.F. 2012. Rapid reef island formation and stability over an emerging reef flat: Bewick Cay, northern Great Barrier Reef, Australia. Geology, 40, 3, 347-350.

Kinlan, B. P. and Gaines, S. D. 2003. Propagule dispersal in marine and terrestrial environments: a community perspective. Ecology, 84, 2007-2020.

Lambeck, K. Woodroffe, C. D. AntoniolI, F. Anzidei, M. Gehrels, W. R. Laborel, J. and Wright, A. J. 2010. Paleoenvironmental records, geophysical modelling, and reconstruction of sea level trends 
and variability on centennial and longer timescales. In: Understanding Sea Level Rise and Variability, J.A. Church, P. Woodworth, T. Aarup and W. Wilson (Eds) Wiley and Sons, UK, 61-121.

Larcombe, P. Carter, R. Dye, J. Gagan, M. and Johnson, D. 1995. New evidence for episodic post-glacial sea-level rise, central Great Barrier Reef, Australia. Marine Geology, 127, 1-44.

Lewis, S. E. Sloss, C. R. Murray-Wallace, C. V. Woodroffe, C. D. and Smithers, S. G. 2013. Post-glacial sea-level changes around the Australian margin: a review. Quaternary Science Reviews, 74, 115138.

Longhurst, A. R. 2010. Ecological Geography of the Sea, Academic Press, 2nd Edition, 560 pp.

Marshall, J. and Davies, P. 1982. Internal structure and Holocene evolution of One Tree Reef, southern Great Barrier Reef. Coral Reefs, 1, 21-28.

McLean, R. Stoddart, D. Hopley, D. and Polach, H. 1978. Sea level change in the Holocene on the northern Great Barrier Reef. Philosophical Transactions of the Royal Society of London A: Mathematical, Physical and Engineering Sciences, 291, 167-186.

Mueller-Dombois, D. and Fosberg, F. R. 1998. Vegetation of the Tropical Pacific islands, Springer Verlag, New York, NY, USA., 733 pp.

Price, J. P. 2004. Floristic biogeography of the Hawaiian Islands: influences of area, environment and paleogeography. Journal of Biogeography, 31, 487-500.

Robinson, L. Elith, J. Hobday, A. Pearson, R. Kendall, B. Possingham, H. and Richardson, A. 2011. Pushing the limits in marine species distribution modelling: lessons from the land, present challenges and opportunities. Global Ecology and Biogeography, 20, 789-802.

Sanmartín, I. Anderson, C. L. Alarcon, M. Ronquist, F. and Aldasoro, J. J. 2010. Bayesian island biogeography in a continental setting: the Rand Flora case. Biology Letters, 6, 703-707.

Smith, J. and Heatwole, H. 1985. Notes on the changing flora of Heron Island and some other coral cays of the Capricornia Group, Great Barrier Reef. Queensland Naturalist, 25, 126-133.

Smith, J. Heatwole, H. Jones, M. and Waterhouse, B. 1990. Drift disseminules on cays of the Swain Reefs, Great Barrier Reef, Australia. Journal of Biogeography, 17, 1, 5-17.

Stoddart, D.1978. The Great Barrier Reef and the Great Barrier Reef Expedition 1973. Philosophical Transactions of the Royal Society of London. Series A, Mathematical and Physical Sciences, 291, $5-22$.

Stoddart, D. 1980. Mangroves as successional stages, inner reefs of the northern Great Barrier Reef. Journal of Biogeography, 7, 269-284.

Stoddart, D. McLean, R. and Hopley, D. 1978. Geomorphology of reef islands, northern Great Barrier Reef. Philosophical Transactions of the Royal Society of London B: Biological Sciences, 284, 3961.

Stoddart, D. R. and Fosberg, F. R. 1991. Phytogeography and vegetation of the reef islands of the northern Great Barrier Reef. Atoll Research Bulletin, 349, 1-22.

Tilman, D. Lehman, C. L. and Thomson, K. T. 1997. Plant diversity and ecosystem productivity: theoretical considerations. Proceedings of the National Academy of Sciences, 94, 1857-1861.

White, I. and Falkland, T. 2010. Management of freshwater lenses on small Pacific islands. Hydrogeology Journal, 18, 227-246.

Whitehead, D. R. and Jones, C. E. 1969. Small islands and the equilibrium theory of insular biogeography. Evolution, 23, 1, 171-179.

Whittaker, R. J. and Fernández-Palacios, J. M. 2007. Island Biogeography: Ecology, Evolution, and Conservation, Oxford University Press.

Woodroffe, C. D. 1986. Vascular plant species-area relationships on Nui Atoll, Tuvalu, Central Pacific: a reassessment of the small island effect. Australian Journal of Ecology, 11, 21-31.

Woodroffe, C. D. and Webster, J. M. 2014. Coral reefs and sea-level change. Marine Geology, 352, 248267. 



\title{
MANGROVES AND CORAL REEFS: DAVID STODDART AND THE CAMBRIDGE PHYSIOGRAPHIC TRADITION
}

\author{
COLIN D. WOODROFFE ${ }^{1}$
}

\begin{abstract}
Mangroves are particularly extensive on sheltered, macrotidal, muddy tropical coastlines, but also occur in association with coral reefs. Reefs attenuate wave energy, in some locations enabling the accretion of fine calcareous sediments which in turn favour establishment of seagrasses and mangroves. Knowledge of the distribution and ecology of both reefs and mangroves increased in the first half of the $20^{\text {th }}$ century. J Alfred Steers participated in the Great Barrier Reef Expedition in 1928, and developed an interest in the geomorphological processes by which islands had formed in this setting. It became clear that many mangrove forests showed a zonation of species and some researchers inferred successional changes, even implying that reefs might transition through a mangrove stage, ultimately forming land. Valentine Chapman studied the ecology of mangroves, and Steers and Chapman described West Indian mangrove islands in the 1940s during the University of Cambridge expedition to Jamaica. These studies provided the background for David Stoddart's participation in the Cambridge Expedition to British Honduras and his $\mathrm{PhD}$ examination of three Caribbean atolls. One of these, Turneffe Islands, is an atypical atoll, with mangroves occupying more than $25 \%$ of the reef platform. In contrast to this atoll-like island, there are other island types on the Belize barrier reef, including similar extensive mangrove islands called 'ranges'. Stoddart compared the more complex of these, comprising shingle ridges and sand cays around which the mangroves occur, with the 'low wooded islands' on the Great Barrier Reef. Many of those that he had mapped were devastated by Hurricane Hattie in 1961, and the opportunity to revisit these, and document the storm damage and subsequent recovery, led to much important evidence for the role of storms in the long-term evolution of both reefs and reef islands. In 1973, Stoddart led the Royal Society and Universities of Queensland Expedition to the northern Great Barrier Reef. During this extensive period of fieldwork, Stoddart and colleagues remapped Low Isles in detail, the best-known of the low wooded islands, and many other islands in less detail. The contrast between islands on the Belize coast with those on the Great Barrier Reef provided many insights into the geomorphology of both reefs and the vegetation of islands that form on them. The physiography of the islands provided many clues to the way they had formed and the processes operating. It became clear to Stoddart that there has been a different sea-level history in these two locations. He was able to observe and infer the response of key habitats to tropical cyclones (hurricanes). In many cases island physiography differs between individual islands, reflecting a broader suite of factors such as inherited topography and morphodynamic feedbacks; in other cases, mangrove establishment appears to have been opportunistic. Subsequent studies have elucidated the stratigraphy and geochronology in some locations; in many cases confirming the hypotheses that Stoddart proposed. His insightful descriptions and meticulous fieldwork have provided a wealth of observational data that have inspired subsequent studies and that will continue to generate alternative hypotheses that future environmental scientists can endeavour to test.
\end{abstract}

\section{INTRODUCTION}

Mangroves grow throughout much of the tropics, extending into subtropical and temperate regions along the eastern margins of continents. Mangrove forests are particularly extensive where low gradient plains have developed in areas of considerable tidal range. Muddy estuarine and deltaic

\footnotetext{
${ }^{1}$ School of Earth and Environmental Sciences, University of Wollongong, NSW 2522, Australia. colin@uow.edu.au
} 
environments associated with the mouths of major rivers support extensive mangrove forests. However, mangroves can also flourish in association with coral reefs. This overview focuses on the occurrence and development of mangroves in relation to reefs, and reconsiders the significant contributions to their study made by David R. Stoddart.

Mangroves, corals and seagrass have co-occurred in shallow tropical seas since the evolution of their constituent taxa in the Cretaceous (McCoy and Heck, 1976). It has become clear that there are interconnections between the ecosystems each support (Mumby, 2006; Harborne et al., 2006; Olds et al., 2013), and interdependencies between these three communities (Saunders et al., 2014; Guannel et al., 2016). Some naturalists have hypothesised that there might be a succession of ecosystems with reefs preparing the way for seagrass, and mangroves subsequently vegetating reef platforms, culminating in the development of islands (Welch, 1963). The role of mangroves in this context intrigued Stoddart, and he investigated this directly both in Belize and on the Great Barrier Reef. His insights stimulated further research in other reef settings. This paper reconsiders these contributions.

\section{MANGROVE FORESTS AND THEIR OCCURRENCE: EARLY IDEAS}

Where several species grow in mangrove forests, they have often been observed to be forming nearly monospecific zones parallel to the shore. The zonation of mangroves led to the concept that there is a temporal succession. One of the most detailed descriptions of the occurrence of the numerous mangrove species within well-developed mangrove forests was on the Malayan Peninsula by Watson (1928). In his monograph, Watson remarked that boundaries between mangrove species were often remarkably distinct, and he related their occurrence to elevation within the tidal frame and the consequent frequency of inundation by tides. However, he recognised that there were 'influencing factors besides the frequency of inundation being drainage, the character of the soil, the age of the swamp, the erosive or accresive [sic] action of the sea, and the artificial conditions brought about by exploitation' (Watson, 1928, p.133). He considered that there was a pattern of development of the mangrove communities, which he called types, with Avicennia and Sonneratia being pioneers on accreting coasts, whereas Bruguiera gymnorhiza marked the final stage typical of the transition from littoral to inland forest. Such patterning is a generalisation and not all types are represented even in extensive swamps, nor do all mangrove forests inevitably pass through the entire sequence of development (Watson, 1928, p.149).

Also in 1928, William Morris Davis produced a detailed synthesis of what he termed, the Coral Reef Problem, reviewing the physiography of coral reefs, reinforcing the evolutionary perspective of reef types propounded by Charles Darwin. Coincidentally in the same year, the Great Barrier Reef Expedition commenced a year-long exploration of the Great Barrier Reef in northeastern Australia. Led by C. Maurice Yonge, the expedition adopted Low Isles, $10 \mathrm{~km}$ northeast of Port Douglas, as its headquarters. Since its early recognition by Cook in 1770, and subsequent description by King in 1819 and MacGillivray in 1848, Low Isles had been referred to as a low wooded island, because of the extensive mangroves covering part of the reef top. The expedition was primarily concerned with the "elucidation of problems which have a direct bearing on ecology (i.e. towards a study of conditions and food-supply in the sea, of feeding and metabolism of corals, of the growth and breeding of marine organisms and so forth)' (Stephenson et al., 1931, p.19). As a component of the expedition, the Royal Geographical Society sponsored J. Alfred Steers of the University of Cambridge to visit Queensland. Steers, a physical geographer, took an interest in the variability of reef islands along the reef (Steers, 1929, 1931). He made use of a 'physiographic sketch map' compiled using a plane-table survey by E.C. Marchant, which outlined the major features of the reef top. Mangroves were not a particularly prominent component of the 1928-1929 Great Barrier Reef Expedition itself; however, it was possible to discriminate near continuous areas of mangrove swamp composed primarily of Rhizophora from more open canopies referred to as mangrove park on many of the reef platforms within the inner reef. Particularly significant was a detailed map of Low Isles augmenting the plane-table survey by theodolite triangulation and comparison with aerial photography, prepared by Spender (1930). This was initially used as a base map for the ecological studies, but has since provided a basis for examining geomorphological changes at Low Isles (Hamylton, 122 
2017). The description by Steers (1929), and the mapping by Spender (1930), of Low Isles, had provided an introductory examination of a key island type. Steers called these 'low wooded islands', and his more extensive visit to the Queensland coast in 1936 allowed him to visit and map many more of these complex island types (Steers and Kemp, 1937).

The capacity of Rhizophora to disperse across the ocean had been documented by Guppy (1906), and the viviparous nature of its propagules had been described in detail by Bowman (1917). Observation of seedlings established in shallow water and the cohorts of saplings that can eventuate, together with the tendency for zonation, gave rise to the view that one mangrove species 'prepares the way' for another (Banijbatana, 1958; Kuenzler, 1974). For the mangrove zones to be part of a temporal sequence there would need to be a mechanism by which one species facilitated replacement by the next, and this was postulated to be the vertical accretion of the surface of the substrate. Slowing of water movement within the above-ground root systems of mangroves, whether stilt-like prop roots or peg-like pneumatophores, was considered to lead to increased sediment deposition. Accretion reduces the frequency of inundation and was believed to trigger species change (Chapman, 1944; Fosberg, 1966). In this way, mangroves had been considered by some to be 'makers of land' (Vaughan, 1909) and even 'trees that walk to the sea' (Hodge, 1956).

\section{WEST INDIAN MANGROVES}

Mangrove forests in the West Indies are composed of three principal mangrove species, the red mangrove Rhizophora mangle, the black mangrove Avicennia germinans and the white mangrove Langucularia racemosa. Of these, Rhizophora is almost always found on the seaward margin with the other mangroves behind, implying a simple zonation. Valentine Chapman synthesised the distribution of mangroves throughout the tropics in his book, Mangrove Vegetation (Chapman, 1976). His early work had been on the mangroves of Jamaica. In 1939, while at Gonville and Caius College, he had led the University of Cambridge expedition to Jamaica. Here he had worked with Steers mapping the cays on the southern coast, particularly those in Portland Bight and Kingston Harbour. Whereas Steers described the physiography of several of the reef islands in Port Royal, Portland Bight and elsewhere around Jamaica (Steers, 1940a, 1940b), Chapman focused on the ecology of the mangroves. Chapman stressed that whereas the distribution of mangroves may be climatically determined, 'there is also a physiographic element in their formation' (Chapman, 1944, p. 427).

The dichotomy between reef mangroves and mud mangroves had been identified for some time. However, on the University of Cambridge expedition to Jamaica, Chapman and Steers mapped and described a variety of islands associated with the coral reefs. They discovered that mangroves also grew on sand, particularly calcareous sand of reefal origin in which the alga Halimeda was a conspicuous component (Steers, 1940a; Steers et al., 1940). It was clear that mangrove seedlings had established sporadically amid coral boulders on several of the islands, or in particularly sheltered leeward shores on small cays. In these situations there was little evidence to support mangroves building land; 'the presence of mangrove is more a matter of chance arrival and the establishment of a seedling' (Chapman, 1976, p. 9). Steers (and Lofthouse) mapped Pigeon Island in Portland Bight, an island partially surrounded by shingle and partially by sand, with mangroves fringing a lagoon in the centre. He compared this, and nearby Salt Island, with the low wooded islands of the Great Barrier Reef, although stressing that there was not a prominent conglomerate platform (which he called a promenade) in the Jamaican case (Steers, 1940a).

Also significant was the situation where the mangrove forest, particularly along the Palisadoes of Port Royal near Kingston, was underlain by peat. Chapman described this, saying:

'This marine peat develops only in areas where there is very little or no supply of silt in the water, and in these circumstances it is very clear that the mangroves, particularly the Black [Avicennia] and White [Laguncularia], are bringing about the formation of new land by a process entirely different from that normally ascribed to them. The usual 
method is by the mechanical trapping of silt, but here it is the actual accumulation of the roots of the plants that is responsible for the development of the new land. So far as is known this is a hitherto undescribed method. The peat is extremely firm, the swamps are readily traversed, and one large area of this type of mangrove swamp is being cleared to form an aerodrome. The formation of new land by this means is much slower than by the trapping of silt. For this reason such swamps show very little change in outline when successive maps are compared' (Steers et al., 1940, p. 320).

In the same year, 1940, and noted in a footnote to the Steers et al. paper, J.H. Davis published one of the most important and influential studies on the geomorphological role of mangroves looking at mangroves and the peat deposits beneath them in southwest Florida. Davis recognised a zonation from seawardmost Rhizophora mangle to more landward Avicennia germinans in the mangroves of Florida, and interpreted this patterning to indicate a temporal sequence of communities culminating in a climax vegetation of tropical forest. Examining the stratigraphy of mangroves and using aerial surveys, Davis inferred considerable accretionary ability within the Rhizophora, which he envisaged to be prograding over the marine shoals of Florida and Biscayne Bays. He indicated that 'if new, mature swamp areas are considered land, then there are more than a thousand acres of recently formed land in the Florida Bay to Biscayne Bay region'. (Davis, 1940, p. 408).

\section{TURNEFFE ISLANDS}

The Turneffe Islands comprise particularly extensive mangrove forests. It is now a conservation area (Turneffe Atoll Management Plan, 2012). The atoll is valued for its populations of manatee, turtles, lobster and conch; it is important as one of the few remaining nesting sites for the American crocodile, and there is tarpon (Megalops atlanticus), permit (Trachinotus falcatus) and bonefish (Albula vulpes) fishing. Although there are no settlements directly on the atoll, there are privately owned properties and a resort as well as educational facilities (Calabash Cay, University of Belize Environment Research Institute, and Blackbird Cay, Oceanic Society).

David Stoddart's PhD through the University of Cambridge considered the offshore reefs to the east of the Belize barrier reef. Entitled Three Caribbean atolls: Turneffe Islands, Lighthouse Reef, and Glovers Reef, British Honduras, it was published in 1962 as Atoll Research Bulletin no. 87 (and also available through the Louisiana State University Coastal Studies Institute, as contribution no 62-3, being the seventh part of the eleventh in a series of reports obtained under project Nonr 1575(03), Task Order No NR 388002 of the Geography Branch of Naval Research). Of the three atolls, Turneffe Islands are composed of particularly extensive mangrove forests, and is therefore a focus for more detailed description in this overview.

The study formed a part of a broader description of the cays of Belize (then known as British Honduras), undertaken from the University of Cambridge as part of the Cambridge Expedition to British Honduras, 1959-1960, led by John Thorpe. David Stoddart joined the expedition as a geographer, although he subsequently jested that he 'knew not a single thing about any of the plants and animals, both terrestrial and marine' (Stoddart, 2001, p. 243). Aboard a vessel called the Tortuga, the members visited much of the barrier reef and its islands, as well as the outlying atolls. These islands were poorly understood, few had been described since they were charted by the British hydrographer Richard Owen in the 1830s (Figure 1). Coincidentally, they had also been the object of preliminary study by Don Vermeer from the Department of Geography at Berkeley (Vermeer, 1959). Vermeer had classified the cays of the

reef into i) sand cays, ii) mangrove cays, and iii) mangrove-sand cays, which he regarded as a transition type. Stoddart followed this broad classification, and recognised that 'one might say that Turneffe is really one large mangrove-sand cay' (Stoddart, 1962a, p. 116).

The Turneffe Islands are a reef platform with an area of $525 \mathrm{~km}^{2}$ (Figure 2). Mangroves are particularly extensive, much of the perimeter of Turneffe Islands is fringed with mangrove islands 


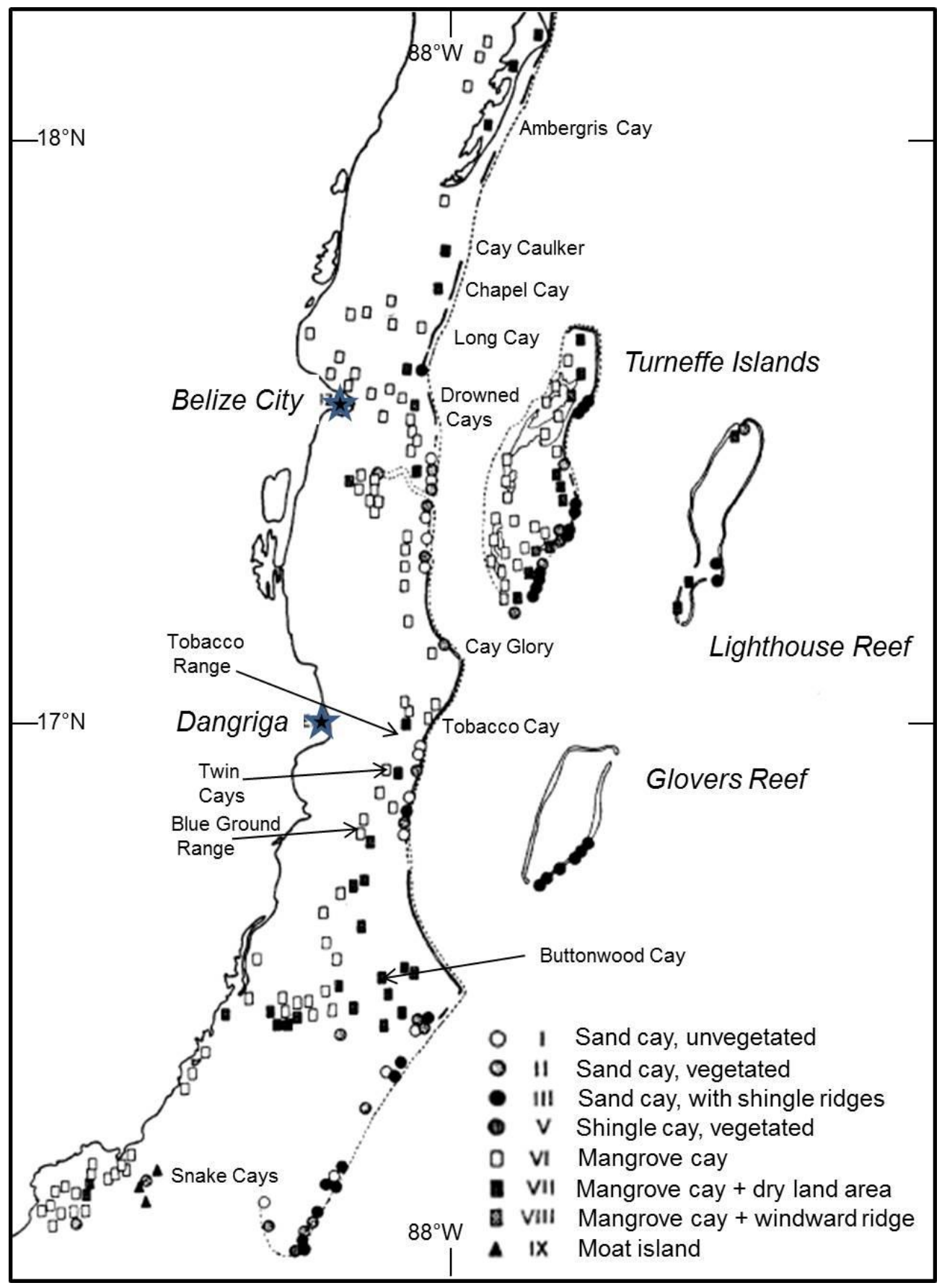

Figure 1. The Belize Barrier Reef, showing the location of the three Caribbean atolls, Turneffe Islands, Lighthouse Reef and Glovers Reef, that Stoddart described for his $\mathrm{PhD}$, and his classification of other island types along the length of the reef (after Stoddart, 1965). 


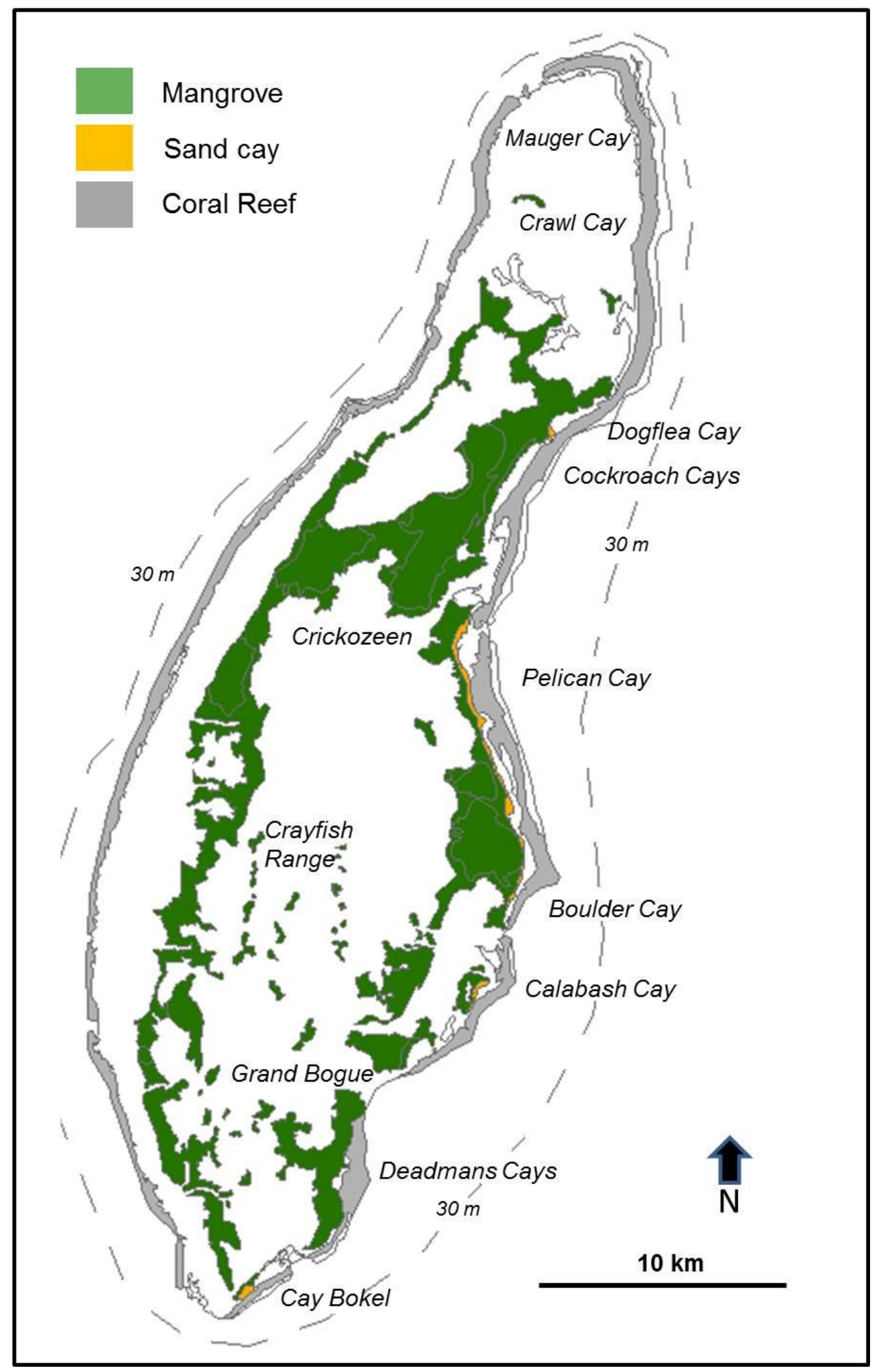

Figure 2. Turneffe Islands, on which mangroves, primarily Rhizophora mangle, occupy more than $25 \%$ of the reef platform (mapping following Meerman, 2006). 
covering $>25 \%$ of the platform area. A sponge industry flourished on Turneffe in the early 1900 s, but collapsed in the 1930s, and has only been intermittently restored. Although termed an atoll, in his 1962 thesis Stoddart recognized that the presence and distribution of mangroves on this atoll-like reef appeared to be almost unique, as nothing quite comparable had been described in the literature (Stoddart, 1962a, p.127). He concluded that the reef did not really fall into the stricter definition of an atoll. Turneffe is relatively sheltered behind Lighthouse Reef from the prevailing northeast trade winds for most of the year, but may be exposed to 'northers', high pressure fronts moving down from the north, and occasional hurricanes from April to October. The region is microtidal, with tidal range around $50 \mathrm{~cm}$. From Mauger Cay in the north to Cay Bokel in the south, Turneffe Atoll is $50 \mathrm{~km}$ long. The eastern reef rim consists of a reef crest with Acropora palmata and Orbicella (Montastraea) annularis prominent on the reef front. Islands occur intermittently along this eastern rim; small sandy islands make up Deadmans Cays in the south and Dogflea and Cockroach Cays in the north. Behind these tiny sandy cays, a more continuous line of mangrove occurs, interrupted by Northern Bogue to the north, Grand Bogue in the southeast, and several smaller channels also called bogues at various other places along this margin. The mangrove fringe on the eastern margin, reaching more than $3 \mathrm{~km}$ wide in places, is relatively exposed, and a discontinuous sand and shingle ridge has formed from reefal sediments swept across the reef flat. This is up to $200 \mathrm{~m}$ wide and rises about 1-2 $\mathrm{m}$ above the reef flat. It supports coconuts in places, but is elsewhere covered by strand vegetation.

The eastern cays on Turneffe were among the first islands surveyed, and the sand cays were examined in greater detail than the extensive mangrove islands. Whereas sand cays were surveyed by pace and compass, mangrove islands:

'present special problems and cannot be surveyed to the same standards as dry land areas. Where mangrove zones on sand cays are less than 100 yards long the traverse was normally carried to seaward of them, but this was liable to disruption by deepening water, softening bottoms, and inquisitive sharks and barracuda.' (Stoddart, 1962a, p.129).

The western reef rim of Turneffe is still lower in terms of wave energy, and much of the reef crest does not reach the sea surface. Instead, the reef front has a cover of gorgonians and the corals Orbicella (Montastraea), Diploria and the branching Acropora cervicornis, in contrast to Acropora palmata which characterises higher energy reef settings around these atolls. There is then a broad shelving backreef floor, with a cover of the seagrass Thalassia testudinum (and also Syringodium filiforme), until the fairly continuous mangrove fringe that occurs between $600 \mathrm{~m}$ and $3 \mathrm{~km}$ lagoonward of the reef crest. The mangrove fringe is more continuous than on the eastern margin, with 4 or 5 much narrower channels connecting into the central lagoons. A northern lagoon is almost enclosed by mangrove and was not visited by Stoddart, whereas the Central Lagoon (which he called Southern lagoon) and the more open southern lagoon, are accessible through numerous bogues. The lagoons are about 2-3 $\mathrm{m}$ deep, reaching a maximum of $8 \mathrm{~m}$ deep; circulation is restricted and temperatures can reach $30^{\circ} \mathrm{C}$ and salinities of up to 42.5\% (Gischler, 2003). There are several channels between the mangrove islands and these are scoured by tides. They have a muddy floor, with seagrass and Halimeda. Within the lagoon are small mangrove islands, composed predominantly of the red mangrove, Rhizophora mangle, most rising fairly abruptly from the lagoon floor.

\section{HURRICANE HATTIE}

Shortly after Stoddart had completed mapping of the cays of Belize, one of the most devastating hurricanes to hit the region passed across Turneffe Islands and the barrier reef. It provided the opportunity to revisit and remap islands. The account of the damage and subsequent recovery represents one of the best documented studies of these phenomena in any reef environment (Stoddart, 1962b, 1963, 1969, 1971).

Stoddart had identified damage to the mangroves that he attributed to hurricanes in his early 
studies, but their role was starkly demonstrated by the passage of Hurricane Hattie on 30-31 October 1961. The storm, a Category 5 hurricane on the Saffir-Simpson scale, went right over Turneffe and had intense winds of $240 \mathrm{~km} / \mathrm{h}$ with gusts of more than $320 \mathrm{~km} / \mathrm{h}$ (Stoddart, 1963). The eye of the hurricane appears to have passed over Pelican Cay on Turneffe around midnight (Stoddart, 1963, p. 11). Within a few months of the storm, Stoddart re-surveyed cays he had mapped in 1960. The most severe damage was experienced along a 40-km wide track; the storm surge reached $4.2 \mathrm{~m}$ high at Cay Caulker, increasing to 6 $\mathrm{m}$ at the mainland coast (Stoddart, 1963).

The larger islands survived better than the smaller ones, and those with a protective ridge to their windward fared better than those without. Damage to mangroves included extensive mortality and defoliation; mechanical damage, stem breakage and erosion of substrates were apparent. Greater damage was recorded on cays that had been disturbed by human interference. In the zone of maximum damage, where the storm surge had been greatest, mangroves were exposed to inundation and wave action. There were areas where trees were felled by the wind, falling in a range of directions rather than just one single direction. On Turneffe, damage was greatest to mangroves on the eastern margin of the atoll; almost all were defoliated, though some interior protected areas remained with leaves. Stoddart inferred that wave action played a major role in stripping the leaves. Regrowth of leaves on some trees was already apparent in 1962, but others remained without leaves in 1965 and were evidently killed as a result of passage of the hurricane. Mangroves on Crayfish Range and adjacent islands in the centre of Turneffe were largely defoliated, whereas only those on the eastern margin of islands to the west of the atoll lost their leaves. The considerable volumes of water driven into the lagoon by the surge, resulted in scouring of channels through the mangroves on the western margin, with oversteepening of banks and scouring of sediment from the floor, causing deposition of sandy deltas at their western exit. Stoddart described dislocation of blocks of mangrove substrate adjacent to Crickozeen Creek on the west, in what he inferred to have been rotational slumping (Stoddart, 1963). Many of the areas had not recovered by 1965, although the overall perimeter of mangrove occurrence changed little after the storm, for example at Cockroach cays (Stoddart, 1969).

\section{MANGROVE ISLANDS OF THE BELIZE BARRIER REEF}

Stoddart mapped, and re-mapped, the numerous cays on the Belize barrier reef and within the lagoon (Figure 1). In 1982, he extended an earlier classification (that distinguished 9 types of island, (Stoddart, 1965; see Figure 1) to recognise the following 11 types of island (Stoddart et al., 1982): i) unvegetated sand cay, ii) vegetated sand cay, iii) unvegetated shingle cay, iv) vegetated shingle cay, v) sand and shingle cay, vi) mangrove cay, vii) shelf islands, viii) mangrove cay with dry sand areas, ix) mangrove range, $\mathrm{x}$ ) moat islands, and $\mathrm{xi}$ ) coastal barrier islands (which occur along the mainland coast and originate as a part of beach processes on that coast, such as cuspate foreland formation, rather than being directly associated with the reef).

Mangrove cays had been recognised by Vermeer (1959), and occur within the lagoon and not on the outer barrier reef itself. His category of mangrove-sand islands contains the class mangrove cay with dry sand areas, which comprise particularly those many islands dominated by mangrove but on which a sand ridge accretes on the windward side, as typified for the eastern margin of Turneffe Islands. Shelf islands are a relatively restricted category that are outlined by Ebanks on the shallow shelf north of Belize City, formed 'by sediment accretion on a partly submerged topographic prominence' (Ebanks, 1975, p.277). The term 'mangrove range' describes the extensive and more complex elliptical islands of dense mangrove, with numerous interior lagoons or meandering creeks. The term 'moat islands' was applied by Stoddart to several islands formed on patch reefs in the southern lagoon, which comprise a windward shingle ridge, shallow reef-top lagoon, interior mangrove swamp, and leeward sand cay. The islands had a moat, a slightly deeper section of the reef surface, and he noted analogies between these and the 'low wooded islands' on the Great Barrier Reef (Stoddart, 1965). Plants of the larger mangrove islands on which there are sandy or shingle ridges are distinctive from vegetation of sand cays on the reef edge, with many more grasses, sedges and succulents (Stoddart et al., 1982, p.67). 
Mangrove islands are absent from exposed reef flats, being found only in the lagoon, where they may have shingle or sand ridges on the windward side in some cases, but in lower energy settings may be just mangrove (Stoddart, 1965). Peat accumulates beneath mangroves, particularly Rhizophora, but some sediment may be accreting onto these islands to form the ridges where they are exposed to sufficient energy. Vermeer (1959) had hypothesised that ridges had formed when the sea level had been higher, but Stoddart was able to dispel this idea, postulating instead that:

'this general energy model represents the fundamental control of cay types, the presence or absence of islands depending largely on the existence of a geometrically suitable foundation at a suitable depth at any point in the energy spectrum' (Stoddart, 1965, p. 142).

Under these circumstances, the nature of the island and the extent of mangroves on them depended on the variability and strength of wind, effective fetch, depth of water to windward, and local factors of reef depth and geometry, and was not a response to changes of sea level.

In the northern lagoon, Stoddart described numerous large mangrove islands between Cay Chapel and Belize City $\left(17^{\circ} 30^{\prime} \mathrm{N}\right.$ to $\left.17^{\circ} 45^{\prime} \mathrm{N}\right)$. Long Cay and the northernmost of the Drowned Cays comprised mangrove-sand cays with a narrow windward sand ridge on which coconuts grow, whereas the remainder (Hicks Cays, Montego and Frenchman's Cays, Hen and Chicken Cays and Rider's Cays) consist entirely of mangrove (Stoddart et al., 1982). Many of these islands are dissected by deep meandering channels flushed by strong tidal currents. The larger east-west channels are called bogues. Similar mangrove islands occur at the inner margin of the Belize Deepwater Channel, such as Grennel's Cay and One Man Cay.

Within the central lagoon, the lagoon floor increases in depth from the mainland to depths of 20$24 \mathrm{~m}$, and with a reef rim, or barrier platform, 5-8 km wide and 4-6 m deep. Mangrove islands occur on the inner margin of this barrier platform; most are linear cays oriented north-south, and lack windward sand ridges. South of $17^{\circ} \mathrm{N}$ these mangrove islands become larger and more complex, several are elliptical in shape and are known as mangrove ranges.

Tobacco Range is an elliptical array of mangrove islands about $4.8 \mathrm{~km}$ long and $1.8 \mathrm{~km}$ wide, and has a central lagoon generally around $2 \mathrm{~m}$ deep. A seaward sand ridge occurs at its northern end, up to 18 $\mathrm{m}$ wide with coconuts, Tournefortia, Sesuvium and a typical strand vegetation. Rhizophora has established in places on the eastern margin of this sand ridge which shows evidence of erosion and retreat westwards (Stoddart et al., 1982, p.49). Hurricane Hattie caused destruction of mangrove on Tobacco Range; death of a zone of mangrove up to $100 \mathrm{~m}$ wide is indicated by standing dead trees seen on several visits to the Range in a zone behind the ridge that has been colonised by Batis maritima.

Twin Cays, also called Water Range, has been the subject of detailed studies. It is $1.4 \mathrm{~km}$ long and $1.1 \mathrm{~km}$ wide and comprises two islands separated by a meandering creek. Apart from small sandy sections at the southern end, this comprises two prominent mangrove islands separated by a meandering central creek. The mangrove vegetation was mapped in 5 classes by Woodroffee (1995): Rhizophora woodland ( $>4 \mathrm{~m}$ tall), Rhizophora thicket (2-4 m tall), Rhizophora scrub ( $<2 \mathrm{~m}$ tall), Avicennia woodland, and Avicennia open woodland with Rhizophora. Unvegetated flats, or poorly vegetated areas, persist on both Twin Cays and Tobacco Range. Taller Rhizophora dominates much of the perimeter of the ranges, with Rhizophora thicket the most widespread of the vegetation types. Rhizophora scrub is frequently found in the interior of ranges, often adjacent to unvegetated flats, but there are exceptions where the margin of the range has been eroded and scrub occurs next to open water. On the eastern margin of Tobacco Range there are locations where Avicennia woodland is exposed on the edge of the island, evidently as a consequence of erosion of the shoreline and the underlying peat (Woodroffe, 1995, p. 5). Buttonwood Cay has extensive Conocarpus erectus with well-developed coconuts in the middle, surrounded by mangrove, primarily Rhizophora.

Particularly noteworthy are the cays of the Port Honduras Bight between Punta Gorda and Punta Ycacos. The Snake Cays represent complex islands, termed moat islands by Stoddart. They lie on reef platforms that rise from lagoon depths of 20-30 m. Within the Snake group there are islands composed of 
a windward shingle ridge and leeward sand cay, with mangrove covering varying extends within the interior. East Snake Cay, only $260 \mathrm{~m}$ long, consists of a densely vegetated sand cay (dominated by coconuts and Coccoloba, Cordia, Terminalia and Thrinax) entirely surrounded by shingle ridges, enclosing a moat and mangroves (Stoddart et al., 1982). West Snake Cay has a shingle rampart on its eastern, windward margin; this is about $370 \mathrm{~m}$ long and rises to $1 \mathrm{~m}$ above sea level. A moat behind the ridge is about $100 \mathrm{~m}$ wide and $0.6 \mathrm{~m}$ deep. The mangrove area comprises Rhizophora mangle, Avicennia germinans and the fern Acrostichum aureum, with Rhizophora seedlings also in the moat. The sand cay supports coconuts, but also with Coccoloba and Tournefortia. South Snake Cay is similar but the shingle rampart which is $20 \mathrm{~m}$ wide adjoins the sand cay at each end, meaning that the moat is entirely enclosed. Stoddart's explanation for the complexity of these islands was that they were in a deeper section of the lagoon where wave energy was sufficient to move coarser material and construct the shingle ridges on the windward sides of reef platforms.

Stratigraphy of the islands provides further insights into their formation. The broad pattern of Holocene sedimentation across the Belize shelf was revealed by seismic studies and preliminary drilling by Purdy (974). He indicated that there was Holocene sediment beneath Tobacco Range, and that there was $25 \mathrm{~m}$ of Holocene above terrestrial sediments at East Snake Cay. Detailed stratigraphy of Tobacco Range and Twin Cays has been described by Macintyre et al. $(1995,2004)$. The peat accumulation at these sites have been considered to track sea-level rise in this region (McKee and Faulkner, 2000; Mckee et al., 2007). Mangrove peat has been encountered at the base of numerous cores through Holocene sediments across the Belize barrier reef (Shinn et al., 1982). At Boo Bee Patch reef, just south of these mangrove ranges, a Pleistocene patch reef, upon which the Holocene patch reef now occurs, is surrounded by peat presumed to be of mangrove origin, radiocarbon dated to about 8000 years ago (Halley et al., 1977). Stoddart suggested that mangrove ranges may also be located over Pleistocene topographic highs (Stoddart et al, 1982).

Revisiting many of the islands and resurveying them enabled Stoddart to comment on the general pattern of topographic change. He noted that, of 24 islands mapped in 1960-1961 and again in 1972, 11 had decreased in area and 13 increased, with the aggregated area reducing from 35.7 to 33.3 ha The greatest proportion of change was most marked on the smallest islands (Stoddart et al., 1982). Four modes of change were noted: i) catastrophic change resulting from hurricane damage (particularly Hurricane Hattie), ii) marginal erosion, presumably from such storms, iii) reworking of small islets, especially shingle deposits on windward margins, and iv) accumulation of spits and other ephemeral features. In mapping the mangrove vegetation of Tobacco Range, Twin Cays and Blue Ground Range in 1987, and comparing the ground traverses with aerial photographs of these mangrove ranges taken in 1975, Woodroffe (1995) noted several changes, particularly i) the growth of Batis over areas mapped as unvegetated flat, ii) regrowth of Rhizophora over areas mapped as unvegetated flat, and iii) localised dieback of Avicennia. Storms have left a legacy in these mangrove ranges. A large area of mangrove was devastated at the southern end of Tobacco Range by Hurricane Hattie (Stoddart et al., 1982). Woodroffe (1995) reported erosion around parts of the perimeter of each mangrove range visited in the central barrier reef, indicating gradual contraction of these islands, further confirmed by the greater extent of peat beyond the vegetated shoreline of each island. The numerous stumps of Avicennia seen across much of each range, but particularly in association with the unvegetated flats, appear to have resulted from past hurricanes, many perhaps due to Hurricane Hattie.

\section{LOW WOODED ISLANDS ON THE GREAT BARRIER REEF}

In contrast to the cays of Belize which had received little description prior to 1959-1960 University of Cambridge expedition, the low wooded islands on the Great Barrier Reef had been the 


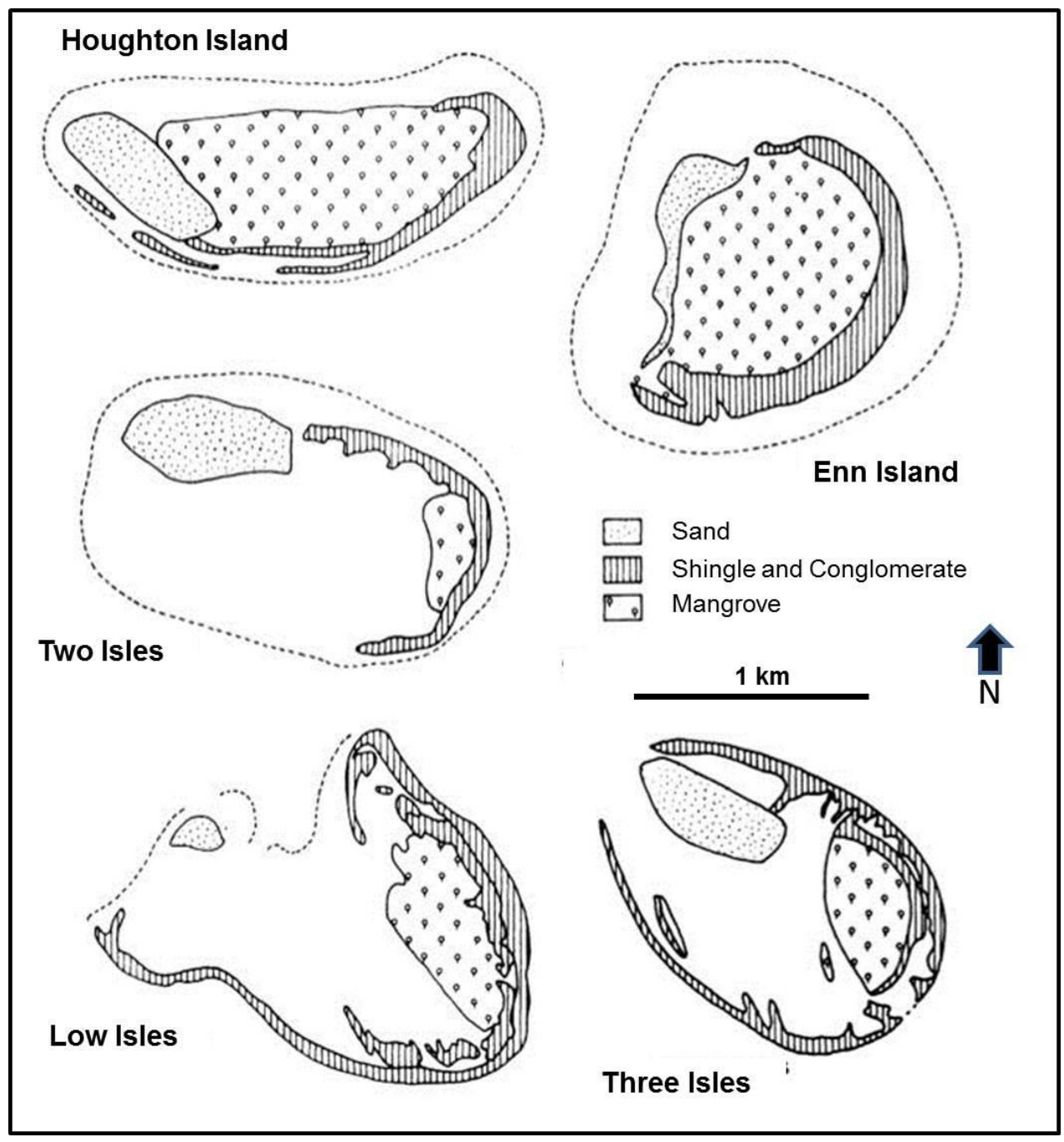

Figure 3. Examples of 'low wooded islands' on the Great Barrier Reef (after Stoddart, 1965).

subject of several notable previous studies. Steers (1929), reporting on the 1928 expedition, described the low wooded islands. The term in general use on Admiralty charts referred to a reef platform on which there were two types of island, a leeward sand cay like those elsewhere on the reef, and what Steers called a mangrove-shingle island (Figure 3 ).

For Low Isles it could justifiably be said that "no coral island in the world has been so intensively studied over so long a time' (Stoddart et al., 1978a, p. 63; Hamylton, 2017). Since being sighted by James Cook on the Endeavour in 1770, it was mentioned by King in 1819 and MacGillivray on the Rattlesnake in 1848. It had been the base for the year-long Royal Society expedition led by Sir Maurice Yonge in 1928-1929, and Steers (1929) provided a description based on a physiographical map by E.C. Marchant. The oval sand cay to the northwest, vegetated with Tournefortia, Scaevola, Casuarina and Ipomoea, he likened to sand cays elsewhere, and contrasted this with the shingle ridge that formed the basis of the mangrove-shingle island (or islands in the case of Three Isles). Landward-dipping bedding of the shingle was noted, and erosion along the windward (eastern) margin had resulted in what he then called 'basset edges'. Shingle tongues occurred on the inner side, in places with a shallow moat, and elsewhere with mangroves (Steers, 1929). The mangrove was extensive, dissected by openings and areas of dead mangrove and underlain by a dark mud, adjacent to which is what he termed the pseudo-lagoon, a shallow region, drying over much of its surface at low tide with some corals and Tridacna clams. Steers recognised that 'the mangroves are rapidly colonizing these lagoons, and at high water the advancing line 
of vegetation presents a very striking picture' (Steers, 1929, p.254). He also commented on the case of one of the Turtle group where the mangrove was continuous from the shingle to the sand cay and the pseudo-lagoon was absent, which he postulated might be due to the initial size of the reef platform on which the islands had developed. Steers was less clear about the formation of the mangrove-shingle island and whether it was of the same age as the sand cay, or whether sand cay formation preceded development of the mangroves, which subsequently obstructed the delivery of skeletal reef material to the cay.

A particularly detailed map of Low Isles was prepared by Spender through triangulation with a theodolite. Spender considered that

'There is more than a temptation to take it as self-evident that the island-reefs [his term for low wooded islands] of the Queensland coast tend to develop towards an island where mangroves cover the entire space between the rampart and the cay......But the evidence of the reefs I take to be otherwise. The relics of previous movements seen in the sand-rock, conglomerates, and occasional dead or dying mangroves, the limits of the mangroveswamp, and also the historical evidence, all suggest that the islands have existed long enough to find an equilibrium of the elements on the reef, about which distribution alternate growth and destruction make small oscillations' (Spender, 1930, p. 290).

Spender saw the islands as having reached a 'comparatively stable and balanced finality'. He commented on apparent loss of mangrove from a shingle tongue at the south of the reef, where there were then a few battered and ancient Rhizophora trees. Stoddart commented that this had in 1973 many young recently established mangroves. Comparison of 1928 and 1945 aerial photographs indicated that patches of mangrove had been expanding and coalescing, and for Fairbridge and Teichert (1948), in comparison with Bewick Island, Houghton Islands and Low Wooded Island itself, it seemed 'it would only be a question of time until most of the Reef Flat would be covered with dense mangrove growth'.

A further reconnaissance of 27 islands in 1936 enabled Steers and Kemp (1937) to consider the processes of formation of low wooded islands. Low Isles represented the southernmost of these islands but was not necessarily typical, others containing mangrove coverage of differing proportions of the reef platform, in some cases with no lagoon present. All occurred where the outer reef was relatively close to the mainland in contrast to further south on the Great Barrier Reef. In reassessing his earlier discussion of the formation of low wooded islands, Steers drew attention to an unnamed island in the Turtle group where a sand cay and shingle ridge are accumulating contemporaneously. Although shingle ramparts here did not appear to have thwarted cay accretion, he speculated that further consolidation of the shingle ridges would ultimately starve the cay of sand. Storms were realised to punctuate development, at least until beachrock cementation and denser vegetation gave the cay greater stability. Spender hypothesised a cycle, implying that the islands were in equilibrium. Steers preferred a view that a prominent platform on the islands and on much of the Queensland coast recorded a higher sea level and that the bassett edges dated from this time. He felt that the extent of mangrove on individual reefs varied in size partly according to the area of the reef, but also fortuitously in relation to a variety of factors such as the supply of seedlings and tidal conditions. Given time mangroves could cover the reef top and also enclose the cay (Steers and Kemp, 1937, p133). Observations of the 1934 cyclone and its effect on Low Isles were also summarised by Steers and Kemp (1937), but had been described in detail by Moorhouse (1936).

The Royal Society and Universities of Queensland Expedition to the northern Great Barrier Reef took place from mid-July to mid-November in 1973, led by David Stoddart. It comprised three phases, examining the reef and reef islands between $11^{\circ} 30^{\prime} \mathrm{S}$ and $17^{\circ} \mathrm{S}$ and its primary purpose was to understand recent reef history and its response to Holocene sea-level change, and included a range of methodologies such as shallow coring, geophysical surveys, analysis of reef and inter-reef sediments, composition of modern reef communities, as well as an analysis of the geology and geomorphology of reef islands (Stoddart, 1978).

The expedition conclusively demonstrated that this region of northern Queensland had experienced a higher sea level in mid Holocene and that this had had a major influence on the geomorphology of the reef islands (McLean et al., 1978). Since the cessation of upward reef growth, reef 
flats had developed on the reef platforms of the northern Great Barrier Reef (Stoddart et al., 1978b). The reefs were formed over a Pleistocene topography; Pleistocene limestones were encountered at depths as shallow as $4 \mathrm{~m}$ below low water springs in coring on Bewick (Thom et al., 1978), and it was concluded that:

'variation in the depth of the Pleistocene-Holocene disconformity may strongly influence the degree of development of patch reefs and associated cay and mangrove cover. Well-developed 'low wooded islands' (e.g. Bewick) could possess a shallow Holocene reef cap compared with reefs which contain little or no cay development' (Thom et al., 1978, p. 52).

During the expedition, 67 reef islands were mapped by Stoddart; each was surveyed using pace and compass, except Low Isles, which was re-surveyed using a tape and compass to enable more precise comparison with the earlier map of Spender. There have been various attempts to classify reef islands on the Great Barrier Reef, adopting criteria such as sediment type, island location, island shape, or stage of vegetation cover (Hopley, 1982). Stoddart and Steers (1977) advocated a classification that recognised, sand cay, vegetated or unvegetated; sand cay with shingle, generally vegetated; shingle cay, vegetated or unvegetated; mangrove cay; mangrove cay with windward ridge; low wooded island; and emergent limestone island. However, Stoddart et al. (1978b) classified islands studied on the expedition as either unvegetated sand cays, vegetated sand cays, or low wooded islands, if supplied with sufficient sediment, cays were considered to 'mature' from a simple sand cay to developing ramparts and mangrove forests towards an end stage when the platform is covered in vegetation (Stoddart et al., 1978b).

Low wooded islands received particular attention during the expedition. Features characteristic of these islands included an extensive reef flat, ramparts on the windward eastern margin, a 'promenade' of higher conglomerate, partially-lithified shingle deposits, in places standing up from the reef flat as bassett edges where the forests from past storm deposits had been truncated on their windward margin, sand cays on the leeward margin sometimes with adjacent boulder zones, and a mangrove cover of variable extent. Based on these characteristics, Stoddart et al. (1978b) differentiated three types of low wooded island. In the first, on large reef flats, mangroves were of limited extent and the sand cay is distinctly separate (e.g. Lowrie, Two Isles, Three Isles, Pipon, Chapman, Watson and West Hope). In the second, mangroves are more extensive joining the shingle ramparts and the sand cay, such as on Bewick where the entire platform is covered with mangroves, or Newton and Nymph. The third type is typical of the Turtle group which lack a central open flat, but have shingle and mangrove wrapped around the sand cay, whereas a further category is miscellaneous and covers islands not in the previous classes, such as Hampton and Pethebridge Islands.

The resurvey of Low Isles enabled a comparison of change over the 45 years since the detailed mapping by Spender (Stoddart et al., 1978a). Substantial alteration was observed in the size and location of the shingle ramparts which had affected coral growth on the reef flat. Mangroves were observed to have spread considerably at Low Isles, but not to the same extent at Three Isles, which was also mapped both in 1929 and 1973, although not to the same precision. Steers realised that the extent of mangrove on a low wooded island was a function of the development of ramparts. He appeared to consider that ramparts were built by regular wave processes; however the importance of storms was demonstrated by the observations of Moorhouse (1936), who recorded a fresh rampart deposited by the 1931 tropical cyclone, and its reworking landward by the 1934 cyclone. Steers considered that the ramparts were the consequence of former higher sea levels. Whereas the 1973 expedition provided unequivocal support for a sea level higher than present, for which radiocarbon dating of fossil microatolls on many of the reef platforms was particularly convincing evidence, it became apparent that the deposition of ramparts of coarse material by storms occurs episodically on these platforms, and is not directly related to the level of the sea. Fairbridge and Teichert had undertaken a full re-analysis of the ramparts on Low Isles in 1945 (Fairbridge and Teichert, 1948). They identified four ramparts. The first, innermost one was represented by shingle tongues mapped by Spender within the mangroves; their second was equivalent to Spender's inner rampart; the third corresponded to Spender's outer rampart; and their fourth included what was fresh shingle in 1929 but which had had material added by the storm of 1931 . Whereas the inner ramparts 
had not moved in 16 years, the more eastern ramparts did show evidence of reworking landwards. Loose shingle was not obvious when examined in 1954 (Stephenson et al., 1958), and the location of shingle ramparts was typically characterised by bassett edges in 1973 (Stoddart et al., 1978a, p68).

Earlier mapping of Low Isles had mapped the mangrove swamp, an area predominantly of Rhizophora stylosa (initially called $R$. mucronata) up to $20 \mathrm{~m}$ tall, and a more open area or mangrove park of saplings and isolated trees. The mangrove was observed to have been damaged in the storms of 1931 and 1934, but had recovered by 1945 according to Fairbridge and Teichert (1948). Low Isles was visited briefly by Macnae in 1965 who thought there was little evidence of mangrove expansion (Macnae 1966). There was evidence that patches of Rhizophora had been expanding and coalescing throughout the mangrove park (Figure 4). The margin of the mangrove swamp seemed less changeable, except where young Rhizophora were expanding at its northern side, causing Fairbridge and Teichert (1948) to say that it would only be a question of time before the entire reef flat would be covered with mangrove as had already occurred on Bewick, and Houghton or Low Wooded Island. However, the detailed mapping by Stoddart in 1973 confirms an overall trend of extension, indicating that mangrove cover of 21.9 ha in 1929 had extended to 36.5 ha in 1973 (Stoddart et al., 1978b). Comparison of mangrove extent shown on subsequent aerial photographs was undertaken by Frank and Jell (2006); their mapping showed both extension of mangroves onto the ramparts, but also gradual advance of the western margin across the reef flat.

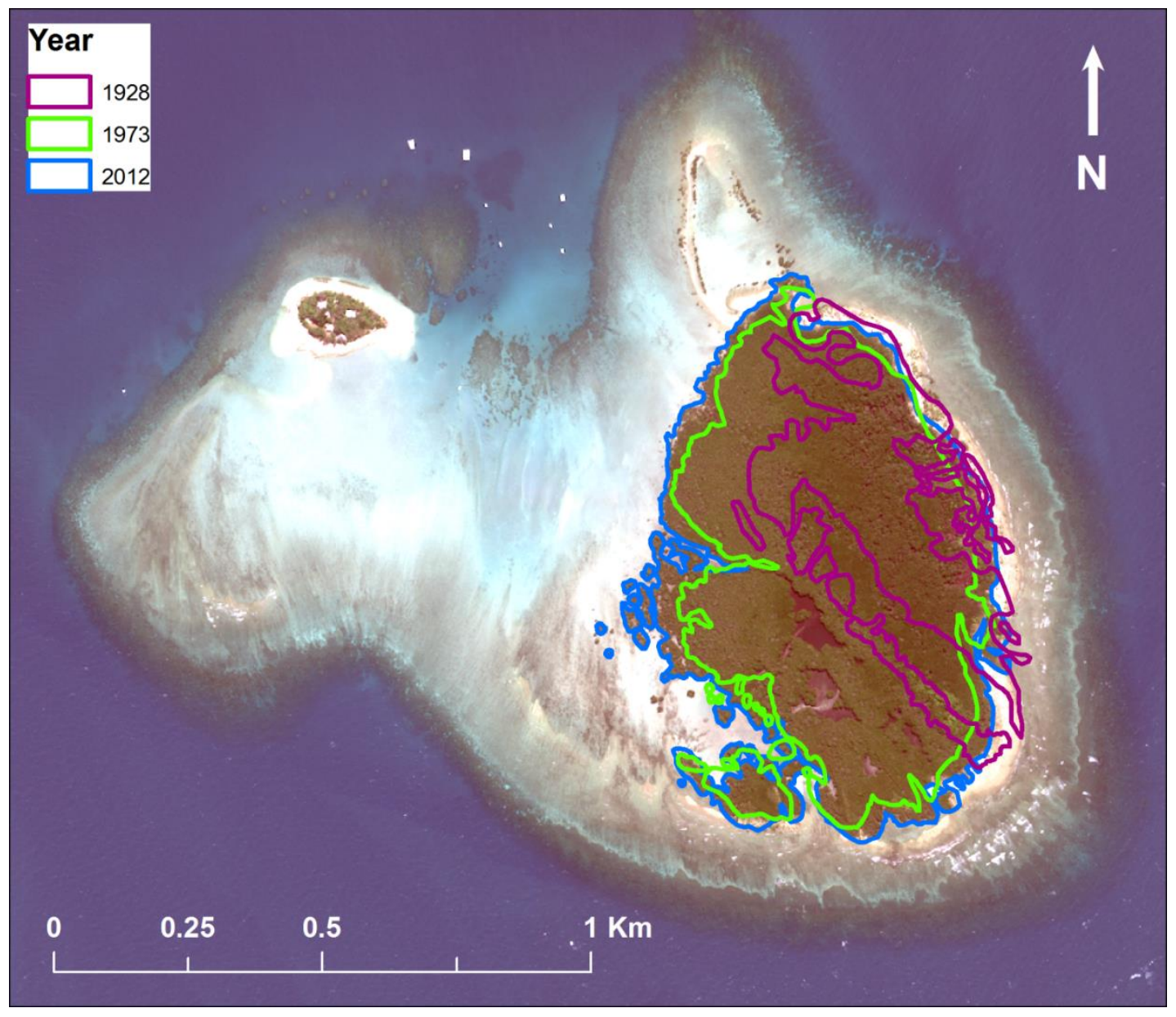

Figure 4. The extent of the mangroves that comprise Woody Island at Low Isles (Great Barrier Reef) in 1928, 1973 and 2012. Outlines are digitised at a scale of 1:500 from the maps produced by M.A Spender during the 1928-1929 Great Barrier Reef Expedition by theodolite triangulation with reference to the first 134 
aerial photographs of Low Isles (purple line) and by D.R. Stoddart during the 1973 Royal Society and Universities of Queensland Expedition to the Northern Great Barrier Reef (green line). Outlines are overlayed onto a WorldView-2 satellite image of Low Isles acquired in 2012 (after Hamylton, 2017).

A general pattern of progressive change is implied by these results. It is not as regular or predictable as Spender or Steers inferred. Low Isles is perhaps not typical of other low wooded islands; it lacks the high promenade, an erosional surface characteristic of the conglomerate of lithified ramparts seen on other low wooded islands. A schematic cross-section of a reef flat on a low wooded island, and the distribution of mangroves across it, is illustrated by Thom, based on fieldwork during 1973 at Bewick (Thom, 1975, p. 475). Mangroves do progressively extend on some reef flats, but it seems likely that this is episodic (Stoddart et al., 1978c). Stoddart addressed this specifically in a synthesis paper on mangroves (Stoddart, 1980). Although not all the maps of individual reef islands were published in the 1978 monograph of the Royal Society, the distribution of mangroves on 21 reefs was analysed in this synthesis. He concluded that the area and spread of mangroves was a function of reef morphology. The most extensive mangrove is Rhizophora stylosa which composes most of the mangrove swamp and mangrove park (the more open areas) over reef flats on the islands, generally up to $15 \mathrm{~m}$ tall. Several other mangrove genera are associated with ramparts, in particular Avicennia marina, Aegialitis annulata, Excoecaria agallocha and Osbornia octodonta. The Rhizophoraceous mangroves Bruguiera spp. and Ceriops spp are reasonably widespread, replacing Rhizophora in the leeward of shingle ramparts on the larger low wooded islands. However, Sonneratia alba is not particularly abundant in this reef setting although forming distinct communities on the seaward margin of mangrove forests on the mainland. Aegiceras corniculatum, Lumnitzera racemosa and Xylocarpus granatum were each recorded from only one island. In contrast to the broader suite of plants that colonise small islands, the diversity of mangroves does not show a relationship to area, but it appears that the establishment of mangroves other than Rhizophora is opportunistic on any reef platform.

Many of the observations of change associated with the shingle ramparts have also had implications for mangroves. Changes to the sand cay were also recorded by the successive mapping. Expansion of Avicennia on ramparts was observed by Fairbridge and Teichert (1948). In places reworking of the shingle has resulted in localised mangrove occurrence on the windward, eastern flank of the rampart. Stoddart (1980) noted that mangroves were extensive where there was fossil reef formed 56,000 years ago. Fossil microatolls indicated that the reef top had reached its vertical limit, and the association of mangroves with these areas, implied that mangrove extent might be a function of the maturity of the reef top, with less mangrove on those reefs where parts of the reef top had not reached this upper threshold. In this sense, Stoddart (1980) considered these mangroves geomorphologically opportunistic in a similar way to the mangrove communities associated with the landforms of deltas and estuaries, described by Thom (Thom, 1967; Thom et al., 1975). The presence of honeycombed rock around the mangrove park on Low Isles has been noted by previous researchers; Spender had seen dead corals amongst the mangroves, and Fairbridge and Teichert (1948) had hypothesised that mangroves might promote the dissolution of calcareous substrate.

An issue that remained a subject of debate was the relative timing of sand cay deposition, shingle rampart formation, and mangrove forest distribution. Earlier researchers had inferred that sand cays were more likely to be formed on the leeward of these platforms before there were well-developed ramparts on the windward or mangrove forests covering substantial proportions of the reef top. Radiocarbon ages of sediments indicated two modal times of island building, $>3,500$ years BP and $\sim 1,500$ years BP, and it was considered that sand cays had begun to form after about 4000 years BP (McLean and Stoddart, 1978). Where there are extensive mangroves on a reef top, there are limited areas for calcareous sediment production, and restricted fetch for wave transport of sediments. Recent investigations on Bewick, which is almost entirely covered by mangroves, indicates further support for initiation of the sand cay around 4,000 years ago and subsequent stability, but the timing of rampart formation and mangrove spread on this reef remains unclear (Kench et al., 2012). 


\section{DISCUSSION}

The differing extent of mangroves on adjacent reef platforms in both Belize and on the Great Barrier Reef, as well as on other reefs in the tropics, poses the challenge of explaining the environmental constraints under which these systems have developed. Observations and inferences by Stoddart address many of the key factors, and will be considered below.

\section{The Physiographic Approach}

Studies of reef islands by Steers and Stoddart were classic examples of the physiographic approach. Physiography is often considered synonymous with physical geography; it is defined as a subfield of geography that studies physical patterns and processes on the Earth. However, it is an essentially field-based and practical approach to understanding nature. T.H. Huxley, in the preface to his book entitled Physiography (Huxley, 1878) was emphatic to differentiate physiography from 'latitudes and longitudes; the heights of mountains; depths of seas; or the geographical distribution of kangaroos and Compositae'. Instead he indicated the need to focus on 'place in nature', and to show the application of 'the plainest and simplest processes of reasoning to any one of these phenomena... to show, lying behind it, a cause, which again suggests another; until, step by step, the conviction dawns upon the learner that, to attain to even an elementary conception of what goes on in his parish, he must know something about the universe; that the pebble he kicks aside would not be what it is and where it is, unless a particular chapter in earth's history, finished untold ages ago, had been exactly what it was' (Huxley, 1878, p. vii - viii). Physiography was also practiced by many of the great North American geoscientists, including John Wesley Powell, Nathaniel S. Shaler and William Morris Davis.

Whereas Huxley was writing a textbook and hence illustrated physiography with a local example likely to be familiar with his readers, namely the Thames as it flowed through parishes in London, Steers and Stoddart, based in the Department of Geography at the University of Cambridge, set out across the world to examine coral reefs, ecosystems that had exerted such a profound influence on Charles Darwin. Much of their science was undertaken during expeditions, and built directly on the close observation and surveying techniques that characterised the navigators, such as Richard Owen, who had gone before them. Detailed mapping, often meticulously undertaken by pace and compass, provided one of the principal sets of data, for, as Stoddart often propounded, a limitless set of further measurements could be derived from an adequate map. On the dynamically changing backdrop of a coral reef, geomorphological processes were continuing to reshape the surface morphology, and the present state was often but a fleetingly ephemeral stage in the most recent chapter of earth's history. Nevertheless, each reef appeared to have undergone its individual journey, partially inherited from underlying topography, constrained by changes of sea level and perturbations from occasionally catastrophic storm impacts.

\section{Sea-Level Changes and Their Legacy}

In 1974, Purdy demonstrated both by coring and seismic traverses across the Belize barrier reef, the significance of inheritance from the antecedent topography of the Pleistocene surface. In some cases, modern reefs were underlain by constructional features associated with the Last Interglacial, but elsewhere such topography was enhanced through karstification during glacial phases (Purdy, 1974). Stoddart had already realised that sea-level changes might be significant, and that underlying topography may be inherited. For example, in describing the north-south alignment of mangrove ranges within the Turneffe lagoon, such as Crayfish Range, he suggested that there might be a bedrock core, or old patch reefs before the eastern rim adopted its present form (Stoddart, 1962a). He commented that the Phillips Petroleum Company was in 1961-1962 drilling a test well west of the northern end of Tobacco Range and recognised the potential insights into shelf structure this could provide (Stoddart, 1963, p. 52). Purdy dated peat around 8000 years BP from depths of $>20 \mathrm{~m}$ on the outer Belize barrier reef, and subsequent work has further documented the most recent rise of sea level over this period (Monacci et al., 2009). 
Stratigraphic studies on these isolated carbonate platforms have subsequently revealed their broad sedimentary history (Gischler, 1994; Gischler and Lomando, 2000). 17 vibrocores from within the lagoon of Turneffe Islands penetrating more than $5 \mathrm{~m}$ into the sediments, indicated a Late Quaternary sedimentary sequence of Pleistocene bedrock, overlain by a shallow soil, then a mangrove peat, culminating in carbonate lagoon sediments dominated by Halimeda but also with shell beds of Codakia orbicularis. Calcareous sediments have a dark brown humic stain from decaying organic matter (Gischler and Lomando, 1999). The thin soil that veneers the Pleistocene limestone contains plant roots on which a radiocarbon age of $7290 \pm 90$ years BP has been obtained. This is overlain by peat derived from the mangroves, within which are reddish roots of Rhizophora, and also traces of pneumatophores of Avicennia; ages of 5610 \pm 80 years BP were derived near the base, with ages of $\sim 4000$ and $\sim 2000$ years BP at shallower depths (Gischler, 2003). Mangrove peat, formed as Chapman realised in areas where there was limited or no supply of terrigenous sediment, and only slow accretion of calcareous reef sediments, reaches its greatest thicknesses where sea-level rise has provided sufficient accommodation space. It has become an important source of paleo-environmental data for the reconstruction of late Holocene sea-level adjustments in this region (Scholl, 1964; Woodroffe, 1981; Hendry and Digerfeldt, 1989).

An inferred evolution of Turneffe indicates that a saucer-shaped limestone island was inundated by the rising sea level, which eventually breached the peripheral bedrock rim. Mangroves flourished in the protected centre of the platform, with average sedimentation rates of $0.82 \mathrm{~m}$ per thousand years (up to a maximum of $1.23 \mathrm{~m}$ per thousand years) interpreted from the cores. Pollen analysis confirms the prominence of Rhizophora, though in one specific core indicating it was replaced by Salicornia around 4000 years ago (Wooller et al., 2009). Open marine conditions typical of Lighthouse and Glovers Reefs did not develop on Turneffe due to the high bedrock elevation implied by the shallow depth to Pleistocene near the perimeter, and its protected nature in the lee of Lighthouse Reef (Gischler, 2003; Gischler and Hudson, 2004).

In describing the mangrove-sand islands of Turneffe, primarily those along the eastern rim, Stoddart realised that the beach ridge was relict in places, because mangroves had established on the reef flat to the east of it. Whereas Vermeer attributed this to a higher sea level, also inferring that other features along the Belize coastline had formed when the sea was higher, Stoddart dismissed this. Stoddart had observed evidence for higher sea level during the mid Holocene from Australia, but was able to reconcile this with the absence of such a highstand in the West Indies as proposed by Adey (1978) and others.

Radiocarbon ages from Turneffe are broadly consistent with the regional sea-level curve derived using a compilation of dates on coral and mangrove remains from throughout the Caribbean, including numerous samples from thick sections of mangrove peat from Tobacco Range and Twin Cays, Belize (Toscano and Macintyre, 2003). Several researchers have suggested that the decelerating pattern of sealevel rise experienced in Belize differs from that for adjacent parts of the Caribbean (Westphall, 1986; Woodroffe, 1988; Gischler and Hudson, 2004; Monacci et al., 2009). Gischler (2006) considered that the Belize data, including basal mangrove peats from Turneffe at $5.3 \mathrm{~m}$ below sea level returning ages of 6,395 , and $2.8 \mathrm{~m}$ from beneath an island returning an age of 6,180 , demonstrated a sea level only $\sim 3 \mathrm{~m}$ below present 6000 years ago. By contrast, Toscano et al. (2018) have shown that there appears to have been little if any compaction of mangrove peats. The pattern of isostatic adjustment across the Caribbean remains unclear; it seems likely that no single pattern of sea-level rise can be used for the entire region (Milne and Peros, 2013; Khan et al., 2017), and further work will be needed to clarify site-specific relative sea-level history.

On the Great Barrier Reef, the 1973 expedition reported conclusive evidence that sea level had reached a level close to present in mid Holocene, and had been above present for much of the past few millennia. Particularly convincing was the record from fossil coral microatolls (Mclean et al., 1978). Subsequent survey and dating of fossil Porites microatolls from along the mainland coast of Queensland by Chappell (1983), derived a record that appeared to show sea level gradually falling smoothly over the past 6000 years from the highstand to present. Nevertheless, there remains debate about whether there may have been oscillations during this period of sea-level fall (Lewis et al., 2008). Evidence from fixed biological indicators (Baker and Haworth, 2000), and that from foraminifera (Woodroffe, 2009), suggest 
there may have been oscillations, but this conflicts with the evidence from microatolls (Lewis et al., 2013). Mangroves do not have a substrate of peat beneath them because the falling sea level has meant little accommodation space for mangrove establishment. Frank and Jell (2006) found only 10-15 cm of organic mud beneath mangroves, which in places were extending over a coral breccia. Thom (1975) reports that depths may be up to 1 metre, and Marshall and Orr (1931) recorded $4 \mathrm{~m}$ of black mud and calcareous sediment from the reef flat of Low Isles. By contrast deeper buried mangrove sediments in the lagoon do record the final stages of postglacial sea-level rise, culminating in the highstand (Grindrod and Rhodes, 1984). The successional stages to which Stoddart referred in his 1980 paper, were inferred to reflect the varying elevation of the reef flat as a consequence of the irregular topography as the reefs grew to reach the constraining sea level, and hence the extent of mangrove covering this reef flat varied as a function of the maturity of the reef platform and the morphodynamic processes that enable mangrove establishment (Stoddart, 1980). These could be highly individual, reflecting for example the emplacement of a shingle ridge by a cyclone, or its breaching by a subsequent storm. Mangroves might opportunistically establish contingent on a reef's past history and subsequent perturbations.

Mangrove is more extensive on islands in Torres Strait than it is in the northern Great Barrier Reef. Here there are islands that are almost entirely mangrove, such as Sassie. At least 35 species of mangrove occur, and no single island has all species on it. Although none of the islands in the Strait are classified as low wooded islands, the reef flats are also known to have developed as a consequence of a mid-Holocene higher sea level (Woodroffe et al., 2000). Emergent microatolls recording this higher sea level occur within mangroves, for example on Yam Island (called Iama, locally). Recent mapping based on aerial photographs from 1974, 1987, 1998 and 2011 has documented expansion of mangroves on this island. On Yam, mangroves covered 67.9 ha in 1974, 64 ha in 1987, 75 ha in 1998 and 78.5 ha in 2011 (Duke et al., 2015). There has been local loss, partly as a result of clearing associated with runway construction during the period of record, however, extension was seen across the reef flat where fossil microatolls provide local microtopographic irregularities which favour sporadic mud accumulation adjacent to such fossil corals. Expansion of mangroves has also been notable on Darnley (Erub) Island, where it is attributed to sedimentation on the reef flat as a result of hillslope erosion on the volcanic island, making further areas of the reef flat suitable for mangrove colonisation (Duke et al., 2015).

\section{The Role of Hurricanes}

Stoddart identified the importance of hurricanes in shaping the reef islands of Belize. He observed evidence of damage to mangroves which he attributed to storms in his 1962 monograph, before witnessing the impact of Hurricane Hattie. The recurrence of storms is recognised as shaping outer cays such as Dogflea Cays on Turneffe (Murray et al., 1999). An unnamed hurricane in 1931 virtually destroyed Belize City, killing over 1000 people. Hurricane Hattie (1961), whose devastation of the coastal ecosystems has been documented (Vermeer, 1963; Stoddart, 1962b, 1963, 1969), led to the relocation of the capital city further inland. Subsequent storms, such as Mitch in 1999 and Keith in 2000 have had further impacts (Murray et al., 1999). McCloskey and Liu (2013) speculated on the phases of carbonate sedimentation within the mangrove peat in several cores; because peat clasts apparently originated from eroded mangrove areas and were deposited contemporaneously within carbonate layers, they considered this indicated high-energy events, perhaps even tsunami.

Mapping of the mangroves of Turneffe has been undertaken as part of broader ecological studies in the western Caribbean, adopting the structural categories recognised by Lugo and Snedaker (1974). Turneffe accounted for 7420 ha of mangrove, $9.4 \%$ of the national total for Belize, comprising 3875 ha of dwarf, 3355 ha of medium and 190 ha of tall forest (Murray et al., 2003). 17.3 ha have been altered by anthropogenic effects, primarily fishing camps. The fringing red mangroves (Rhizophora mangle) occur at the lowest levels in the tidal frame, transitioning into Avicennia germinans at slightly higher elevation with Laguncularia racemosa forming further inland. Dwarf Rhizophora forests have developed in areas of higher salinity (Meerman, 2006). Clearing of land in these mangrove islands is contributing further to the erosion that is occurring (McKee and Vervaeke, 2009). 
In a much more recent study of Turneffe Islands, Chi (2012) has reiterated the important role that hurricanes play, recording that the reef platform had experienced 6 hurricanes and 4 tropical storms in the 157 years from 1851 to 2008. In addition to historical photographs (including access to those taken by David Stoddart) before and after Hurricane Hattie, Chi examined more recent imagery, recording a 26\% loss of vegetated cays between 1945 and 2008 for the northern group of Cockroach Cays, and Calabash Cays (Chi, 2012, p. 90). During this time 4 new cays with less than 0.1 ha formed in the same area. Storms re-activate the ridge along the margin of islands on the eastern rim, reworking sediments onto the prop roots of Rhizophora. In places, carbonate layers within the mangrove peat were attributed to storms. Movement of cays on the eastern margin could be detected, averaging $18 \mathrm{~m}$ to the west, though the centroid of Deadman Cay shifted 43 m westward between 1945 and 2006 . Hurricane Keith (a category 3 hurricane) killed mangrove in the leeward along the Cockroach Cays, but extensive layers of mangrove peat survived erosion or burial. In the 8 years following that storm, mangroves revegetated nearly all of the areas damaged by that storm, probably because trees that survived in the lee of the ridge provided propagules for re-establishment. However, in some areas that had previously been dominated by Rhizophora, these were now colonised by Avicennia with a ground cover of Batis maritima.

These observations reinforce the view that mangroves promoted cay development by stabilising substrate and trapping sediment. Areas of sand planted to coconut were completely stripped of vegetation. Chi revisited three cays in the Cockroach group over a 5-year period to observe the rate of re-foliation, vegetative regrowth and seedling establishment. Also Soldier Cay was visited two weeks after the passage of Hurricane Ivan in 2004; the principal effects of this seemed to be the overwashing of coral rubble into mangroves, with $50 \mathrm{~cm}$ of new material deposited within the mangroves (Chi, 2012, p. 110). Chi showed that areas of mangrove that had been covered with seemingly dead mangrove in 2003 (e.g. the centre of Cockroach Cay-22) had been largely re-colonised by 2008 (Chi, 2012, p. 107). Most cays on the eastern margin of Turneffe reformed in their original locations; Rhizophora extended preferentially on the western side of cays. Material may be moved into mangrove forests on the windward margin, but Macintyre et al. (1987) found little sediment carried more than $150 \mathrm{~m}$ in from the reef crest on Tobacco Reef in Belize.

Cyclone history has also played a role in the case of Low Isles. Mangroves were severely damaged by the cyclone that hit the reef in 1934, and this led to temporary reversal in the otherwise expanding mangrove area on the reef flat. At Low Isles, further changes have occurred since the 1973 mapping by Stoddart. Rasmussen (1986) recorded further adjustments to the ramparts, including a breach into the mangrove swamp at the very southernmost part of the reef platform. She commented that 'it is obvious that initial accumulation of shingle and rampart formations are created during episodic cyclonic events. However, continuing pattern of shingle redistribution takes place under normal weather conditions' (Rasmussen, 1986). The mangrove swamp and mangrove park increased by $75 \%$ from 1929 to 1986 , reflecting in her view both a supply of sediment and of nutrients, the latter related to land use change on the mainland. Frank and Jell (2006) recorded further increase up to 2001.

The individual history of reef tops varies both between platforms on the Great Barrier Reef, and in relation to other reef areas in the region. For example, Spender recognised that differences between Australian low wooded islands (termed island reefs by the 1928 expedition members) and those in Jakarta Bay, Indonesia; the former were on solid reef flat substrate, whereas the latter were on unconsolidated muds, hence their lagoon was less constrained by inheritance form previous morphology. He considered that each had reached, for a given form of the reef and weather conditions, a comparatively stable and balanced finality (Spender, 1930).

The availability of satellite imagery provides much easier access to aerial views of the extent of mangroves on reefs around the world (Figure 4). Broad patterns of change can be examined comparing the field-based maps made by David Stoddart and imagery available on Google Earth. On many low wooded islands, there appears to have been little change in the extent of mangroves, for example Two Isles, Three Isles, and Low Wooded Island. Bewick appears to have reached a stage where there is no longer available space on the reef top for any further mangrove expansion. Mangrove does appear to have continued to increase on Low Isles. Further mangrove appears to have colonised the reef flat as well as 
infilled pools within the existing forest on Coquet and Hampton. On Chapman it has decreased, whereas on Sinclair-Morris and West Pethebridge, both local increase and loss have occurred.

\section{SUMMARY}

David Stoddart was a physiographer of exceptional ability. He participated in a series of expeditions, initially joining a team from Cambridge to examine the islands in British Honduras. His $\mathrm{PhD}$ involved detailed descriptions of the atolls that lie east of the Belize barrier reef, and of those, Turneffe contains particularly extensive mangrove forests. Stoddart himself led many such expeditions. I had the good fortune, when I was studying mangroves in the Caymans Islands under his supervision, to participate in the expedition he led to Little Cayman, and there to be guided by him in the investigation of stands of Rhizophora, both on the reef flat of Little Cayman, but also in small basins within the limestone island interior. As on the Belize islands, including the mangrove ranges and Turneffe, these mangroves were underlain by mangrove peat, formed largely from the fibrous roots of Rhizophora, and they record the final late-Holocene stages of decelerating sea-level rise. The contrasting sea-level history from Belize and Australia explains some of the differences in the morphology and development of the reefs, the mangrove forests, and the adjacent islands when these are formed. Subsequent studies have elucidated the stratigraphy and geochronology in many locations where Stoddart undertook pioneering research; in many cases confirming the hypotheses that he proposed.

However, David Stoddart was always aware of the broader suite of factors, such as inherited topography and morphodynamic feedbacks, that might explain particular sets of circumstances on different reefs. In many cases, mangrove establishment appeared to have been opportunistic, reflecting some contingent event in the past history of that site. His insightful descriptions and meticulous fieldwork have provided a wealth of observational data that have been an incredible inspiration to me, and also many others. His fieldwork followed the fine physiographic traditions adopted by Steers, and to a lesser extent Chapman. He sought to explain nature by knowing it, and was an extremely astute observer. David was always open to alternative hypotheses; he has provided an unparalleled body of scientific observations and he would have wished that these be used by future environmental scientists to test his hypotheses and to generate new ideas.

\section{REFERENCES}

Adey, W. H., 1978. Coral reef morphogenesis: a multidimensional model. Science 202, 831-837.

Baker, R. G. V., Haworth, R. J., 2000. Smooth or oscillating late Holocene sea-level curve? Evidence from palaeo-zoology of fixed biological indicators in east Australia and beyond. Marine Geology $163,367-386$.

Banijbatana, D., 1958. Mangrove forests in Thailand, Proceedings of the 9th Pacific Science Congress, pp. 22-27.

Bowman, H. H. M., 1917. Ecology and physiology of the red mangrove. Proceedings of the American Philosophical Society 56, 589-672.

Chapman, V. J., 1944. 1939 Cambridge University Expedition to Jamaica. Part 1. A study of the botanical processes concerned in the development of the Jamaican shoreline. Journal of the Linnean Society (London) Botany 52, 407-447.

Chapman, V. J., 1976. Mangrove Vegetation. J. Cramer, Germany.

Chappell, J., 1983. Evidence for smoothly falling sea levels relative to north Queensland, Australia, during the past 6000 years. Nature 302, 406-408.

Chi, F., 2012. Long-term changes in mangrove forests and cays following hurricanes at Turneffe Islands, Belize. PhD thesis, University of British Columbia, 324 pp. 
Davis, J. H., 1940. The ecology and geologic role of mangroves in Florida. Papers from Tortugas Laboratory 32, 307-412.

Duke, N. C., Burrows, D., Mackenzie, J.R., 2015. Mangrove and Freshwater Wetland Habitat Status of the Torres Strait Islands. Biodiversity, Biomass and Changing Condition of Wetlands, Report to the National Environmental Research Program, Cairns, $117 \mathrm{pp}$.

Ebanks, W. J., 1975. Holocene carbonate sedimentation and diagenesis, Ambergris Cay, Belize, In: Wantland, K. F., Pusey, W. C. (Eds.), Belize Shelf - carbonate sediments, clastic sediments and ecology. American Association of Petroleum Geologists, pp. 234-296.

Fairbridge, R. W., Teichert, C., 1948. The Low Isles of the Great Barrier Reef: a new analysis. Geographical Journal 111, 67-88.

Fosberg, F. R., 1966. Vegetation as a geological agent in tropical deltas, In: Scientific Problems of the Humid Tropical Zone Deltas and their Implications: Proceedings of the Dacca Symposium. UNESCO, pp. 227-233.

Frank, T. D., Jell, J. S., 2006. Recent developments on a nearshore terrigenous-influenced reef: Low Isles Reef, Australia. Journal of Coastal Research 22, 474-486.

Gischler, E., 1994. Sedimentation on three Caribbean Atolls: Glovers Reef, Lighthouse Reef and Turneffe Islands, Belize. Facies 31, 243-254.

Gischler, E., 2003. Holocene lagoonal development in the isolated carbonate platforms off Belize. Sedimentary Geology 159, 113-132.

Gischler, E., 2006. Comment on "Corrected western Atlantic sea-level curve for the last 11,000 years based on calibrated ${ }^{14} \mathrm{C}$ dates from Acropora palmata framework and intertidal mangrove peat" by Toscano and Macintyre. Coral Reefs 22:257-270 (2003), and their response in Coral Reefs 24:187190 (2005). Coral Reefs 25, 273-279.

Gischler, E., Hudson, J. H., 2004. Holocene development of the Belize Barrier Reef. Sedimentary Geology 164, 223-236.

Gischler, E., Lomando, A. J., 1999. Recent sedimentary facies of isolated carbonate platforms, BelizeYucatan system, Central America. Journal of Sedimentary Research 69, 747-763.

Gischler, E., Lomando, A. J., 2000. Isolated carbonate platforms of Belize, Central America: sedimentary facies, late Quaternary history and controlling factors, In: Insalaco, E., Skeleton, P.W., Palmer, T.J. (Eds.), Carbonate Platform Systems: components and interactions. Geological Society, Special Publications, London, pp. 135-146.

Grindrod, J., Rhodes, E. G., 1984. Holocene sea level history of a tropical estuary: Missionary Bay, North Queensland, In: Thom, B.G. (Ed.), Coastal Geomorphology in Australia. Academic Press, Sydney, pp. 151-178.

Guannel, G., Arkema, K. K., Ruggiero, P., Verutes, G., 2016. The power of three: coral reefs, seagrasses and mangroves protect coastal regions and increase their resilience. PLoS ONE 11.

Guppy, H. B., 1906. Observations of a naturalist in the Pacific between 1896 and 1899. II Plant dispersal. Macmillan, London.

Halley, R. B., Shinn, E. A., Hudson, J. H., Lidz, B., 1977. Recent and relict topography of Boo Bee patch reef, Belize. Proceedings of 3rd International Coral Reef Symposium 2, 29-35.

Hamylton, S. M., 2017. Mapping coral reef environments: a review of historical methods, recent advances and future opportunities. Progress in Physical Geography 41, 803-833.

Harborne, A. R., Mumby, P. J., Micheli, F., Perry, C. T., Dahlgren, C. P., Holmes, K. E., Brumbaugh, D. R., 2006. The functional value of Caribbean coral reef, seagrass and mangrove habitats to ecosystem processes. Advances in Marine Biology 50, 57-189.

Hendry, M., Digerfeldt, G., 1989. Paleogeography and palaeoenvironments of a tropical coastal wetland and offshore shelf during Holocen submergence, Jamaica. Paleogeography, Paleoclimatology, Paleoecology 73, 1-10.

Hodge, W. H., 1956. The trees that walk to sea. Nature Magazine 49, 456-459.

Hopley, D., 1982. The Geomorphology of the Great Barrier Reef. Wiley Interscience., New York. 
Huxley, T. H., 1878. Physiography: an introduction to the study of nature. Macmillan, London.

Kench, P. S., Smithers, S. G., McLean, R. F., 2012. Rapid reef island formation and stability over an emerging reef fl at Bewick Cay, northern Great Barrier Reef, Australia. Geology 40, 347-350.

Khan, N., Ashe, E., Horton, B. P., Dutton, A., Kopp, R. E., Brocard, G., Engelhart, S. E., Hill, D. F., Peltier, W. R., Vane, C. H., Scatena, F. N., 2017. Drivers of Holocene sea-level change in the Caribbean. Quaternary Science Reviews 155, 13-36.

Kuenzler, E. J., 1974. Mangrove swamp systems, In: Odum, H. T., Copeland, B. J., McMahan, E. A. (Eds.), Coastal Ecological Systems in the United States. The Conservation Foundation, Washington DC. pp. 346-371.

Lewis, S. E., Wust, R. A. J., Webster, J. M., Shields, G. A., 2008. Mid-late Holocene sea-level variability in eastern Australia. Terra Nova 20, 74-81.

Lewis, S. E., Sloss, C. R., Murray-Wallace, C. V., Woodroffe, C. D., Smithers, S. G., 2013. Post-glacial sea-level changes around the Australian margin: a review. Quaternary Science Reviews 75, 1-24.

Lugo, A. E., Snedaker, S. C., 1974. The ecology of mangroves. Annual Review of Ecology and Systematics 5, 39-64.

Macintyre, I. G., Graus, R. R., Reinthal, P. N., Littler, M. M., Littler, D. S., 1987. The barrier reef sediment apron: Tobacco Reef, Belize. Coral Reefs 6, 1-12.

Macintyre, I. G., Littler, M. M., Littler, D. S., 1995. Holocene history of Tobacco Range, Belize, Central America. Atoll Research Bulletin 430, 1-18.

Macintyre, I. G., Toscano, M. A., Bond, G. B., 2004. Holocene history of the mangrove islands of Twin Cays, Belize, Central America. Atoll Research Bulletin 510, 1-16.

Macnae, W., 1966. Mangroves in eastern and southern Australia. Australian Journal of Botany 14, 67104.

Marshall, S. M., Orr, A. P., 1931. Sedimentation on Low Isles reef and its relation to coral growth. Scientific Reports of the Great Barrier Reef Expedition, 1928-29 1, 93-133.

McCoy, E. D., Heck, K. L., 1976. Biogeography of corals, seagrasses and mangroves: an alternative to the center of origin concept. Systematic Zoology 25, 201-210.

McCloskey, T. A., Liu, K. -B., 2013. Sedimentary history of mangrove cays in Turneffe Islands, Belize: evidence for sudden environmental reversals. Journal of Coastal Research 29, 971-983.

McLean, R. F., Stoddart, D. R., 1978. Reef island sediments of the northern Great Barrier Reef. Philosophical Transactions of the Royal Society, London A 291, 101-117.

McLean, R. F., Stoddart, D. R., Hopley, D., Polach, H. A., 1978. Sea level change in the Holocene on the northern Great Barrier Reef. Philosophical Transactions of the Royal Society, London A 291, 167186.

McKee, K. L., Faulkner, P. L., 2000. Mangrove peat analysis and reconstruction of vegetation history at the Pelican Cays, Belize. Atoll Research Bulletin 468, 45-58.

McKee, K. L., Cahoon, D. R., Feller, I. C., 2007. Caribbean mangroves adjust to rising sea level through biotic controls on change in soil elevation. Global Ecology and Biogeography 16, 545-556.

McKee, K. L., Vervaeke, W. C., 2009. Impacts of human disturbance on soil erosion potential and habitat stability of mangrove-dominated Islands in the Pelican Cays and Twin Cays Ranges, Belize. Smithsonian Contributions to the Marine Sciences 38, 415-427.

Meerman, J. C., 2006. Mangrove and Conservation Value Assessment at Northern Turneffe. Belize Forest Department, Ministry of Natural Resources, Belmopan.

Milne, G. A., Peros, M., 2013. Data-model comparison of Holocene sea-level change in the circumCaribbean region. Global and Planetary Change 107, 119-131.

Monacci, N. M., Meier-Grünhagen, U., Finney, B. P., Behling, H., Wooller, M. J., 2009. Mangrove ecosystem changes during the Holocene at Spanish Lookout Cay, Belize. Palaeogeography Palaeoclimatology and Palaeoecology 280, 37-46.

Moorhouse, F. W., 1936. The cyclone of 1934 and its effect on low isles, with special observations on Porites. Reports of the Great Barrier Reef Committee 4, 37-44. 
Mumby, P. J., 2006. Connectivity of reef fish between mangroves and coral reefs: algorithms for the design of marine reserves at seascape scales. Biological Conservation 128, 215-222.

Murray, M. R., Zisman, S. A., Furley, P. A., Munro, D. M., Gibson, J., Ratter, J., Bridgewater, S., Minty, C. D., Place, C. J., 2003. The mangroves of Belize Part 1. distribution, composition and classification. Forest Ecology and Management 174, 265-279.

Olds, A. D., Albert, S., Maxwell, P. S., Pitt, K. A., Connolly, R. M., 2013. Mangrove-reef connectivity promotes the effectiveness of marine reserves across the western Pacific. Global Ecology and Biogeography 22, 1040-1049.

Purdy, E. G., 1974. Karst-determined facies patterns in British Honduras: Holocene carbonate sedimentation model. American Association of Petroleum Geologists Bulletin 58, 825-855.

Rasmussen, C. E., 1986. An Investigation of Morphological Changes, Low Isles, northern Great Barrier Reef, Australia, Department of Geography. James Cook University, North Queensland, unpublished Honours thesis.

Saunders, M. N., Leon, J. X., Callaghan, D. P., Roelfsema, C. M., Hamylton, S., Brown, C. J., Baldock, T., Golshani, A., Phinn, S. R., Lovelock, C. E., Hoegh-Guldberg, O., Woodroffe, C. D., Mumby, P. J., 2014. Interdependency of tropical marine ecosystems in response to climate change. Nature Climate Change 4, 724-729.

Scholl, D. W., 1964. Recent sedimentary record in mangrove swamps and rise in sea level over the southwestern coast of Florida: Part 1. Marine Geology 1, 344-366.

Shinn, E. A., Hudson, J. H., Halley, R. B., Lidz, B., Robbin, D. M., Macintyre, I. G., 1982. Geology and sediment accumulation rates at Carrie Bow Cay, Belize, In: Rützler, K., Macintyre, I. G. (Eds.), The Atlantic barrier reef ecosystem at Carrie Bow Cay, Belize I: structure and communities.

Smithsonian Contributions to Marine Science, pp. 63-75.

Spender, M. A., 1930. Island reefs of the Queensland coast. Geographical Journal 76, 194-214, 273-297.

Steers, J. A., 1929. The Queensland coast and the Great Barrier Reefs. Geographical Journal 74, 232-257.

Steers, J. A., 1931. A geogrpahical introduction to the biological reports. Great Barrier Reef Expedition Reports 3, 1-15.

Steers, J. A., 1940a. The cays and the palisadoes, Port Royal, Jamaica. The Geographical Review 30, 279-296.

Steers, J. A., 1940b. The coral cays of Jamaica. The Geographical Journal 95, 30-42.

Steers, J. A., Chapman, V. J., Colman, J., Lofthouse, J. A., 1940. Sand cays and mangroves in Jamaica: Cambridge University Jamaica expedition, 1939, meeting of the Society, 15 April 1940. Geographical Journal 96, 305-328.

Steers, J. A., Kemp, F. E., 1937. The coral islands and associated features of the Great Barrier Reefs. Geographical Journal 89, 119-140.

Stephenson, T. A., Stephenson, A., Tandy, G., Spender, M. A., 1931. The structure and ecology of Low Isles and other reefs. The Great Barrier Reef Expedition Reports 3, 17-112.

Stephenson, W., Endean, R., I., B., 1958. An ecological survey of the marine fauna of Low Isles and other reefs. Australian Journal of Marine and Freshwater Research 9, 261-318.

Stoddart, D. R., 1962a. Three Caribbean atolls: Turneffe Islands, Lighthouse Reef and Glover's Reef, British Honduras. Atoll Research Bulletin 87, 1-151.

Stoddart, D. R., 1962b. Catastrophic storm effects on the British Honduras reefs and cays. Nature 196, $512-515$.

Stoddart, D. R., 1963. Effects of Hurricane Hattie on the British Honduras reefs and cays, 30-31 October 1961. Atoll Research Bulletin 95.

Stoddart, D. R., 1965. British Honduras cays and the low wooded island problem. Transactions of the Institute of British Geographers 36, 131-147.

Stoddart, D. R., 1969. Post-hurricane changes on the British Honduras reefs and cays: re-survey of 1965. Atoll Research Bulletin 131. 
Stoddart, D. R., 1971. Coral reefs and islands and catastrophic storms., In: Steers, J.A. (Ed.), Applied Coastal Geomorphology, pp. 155-197.

Stoddart, D. R., 1978. The Great Barrier Reef and the Great Barrier Reef Expedition 1973. Philosophical Transactions of the Royal Society of London. A 291, 5-22.

Stoddart, D. R., 1980. Mangroves as successional stages, inner reefs of the northern Great Barrier Reef. Journal of Biogeography 7, 269-284.

Stoddart, D. R., 2001. Be of good cheer, my weary readers, for I have espied land. Atoll Research Bulletin 494, 235-272.

Stoddart, D. R., McLean, R. F., Hopley, D., 1978b. Geomorphology of reef islands, northern Great Barrier Reef. Philosophical Transactions of the Royal Society London B 284, 39-61.

Stoddart, D. R., McLean, R. F., Scoffin, T. P., Gibbs, P. E., 1978a. Forty-five years of change on low wooded islands, Great Barrier Reef. Philosophical Transactions of the Royal Society of London. B 284, 63-80.

Stoddart, D. R., McLean, R. F., Scoffin, T. P., Thom, B. G., Hopley, D., 1978c. Evolution of reefs and islands, northern Great Barrier Reef: synthesis and interpretation. Philosophical Transactions of the Royal Society of London. B 284, 149-159.

Stoddart, D. R., Fosberg, F. R., Spellman, D. L., 1982. Cays of the Belize barrier reef and lagoon. Atoll Research Bulletin 256, 1-76.

Thom, B. G., 1967. Mangrove ecology and deltaic geomorphology: Tabasco, Mexico. Journal of Ecology 55, 301-343.

Thom, B. G., 1975. Mangrove ecology from a geomorphic viewpoint, In: Walsh, G.E. (Ed.), International Symposium on the Biology and Management of Mangroves, pp. 469-481.

Thom, B. G., Orme, G. R., Polach, H. A., 1978. Drilling investigations of Bewick and Stapleton Islands. Philosophical Transactions of the Royal Society, London A 291, 37-54.

Thom, B. G., Wright, L. D., Coleman, J. M., 1975. Mangrove ecology and deltaic-estuarine geomorphology, Cambridge Gulf-Ord River, Western Australia. Journal of Ecology 63, 203-222.

Toscano, M. A., Macintyre, I. G., 2003. Corrected western Atlantic sea-level curve for the last 11,000 years based on calibrated ${ }^{14} \mathrm{C}$ dates from Acropora palmata framework and intertidal mangrove peat. Coral Reefs 22, 257-270.

Toscano, M. A., Gonzalez, J. L., Whelan, K. R. T., 2018. Calibrated density profiles of Caribbean mangrove peat sequences from computed tomography for assessment of peat preservation, compaction, and impacts on sea-level reconstructions. Quaternary Research 89, 201-222.

Vaughan, T. W., 1909. The geological work of mangroves in southern Florida. Smithsonian Miscellaneous Collection 52, 461-464.

Vermeer, D. E., 1959. The cays of British Honduras. Department of Geography, Berkeley.

Vermeer, D. E., 1963. Effects of Hurricane Hattie, 1961, on the cays of British Honduras. Zeitschrift für Geomorphologie 7, 332-354.

Watson, J. G., 1928. Mangrove forests of the Malay Peninsula. Malayan Forestry Records 6, 1-275.

Welch, B. L., 1963. From coral reef to tropical island via Thalassia and mangrove. Virginia Journal of Science 14, 213-214.

Westphall, M. J., 1986. Anatomy and history of a ringed-reef complex, Belize, Central America. MSc thesis, University of Miami.

Woodroffe, C. D., 1981. Mangrove swamp stratigraphy and Holocene transgression, Grand Cayman Island, West Indies. Marine Geology 41, 271-294.

Woodroffe, C. D., 1988. Mangroves and sedimentation in reef environments: indicators of past sea-level changes and present sea-level trends? Proceedings 6th International Coral Reef Congress, Townsville 3, 535-539.

Woodroffe, C. D., 1995. Mangrove vegetation of Tobacco Range and nearby mangroves, central Belize barrier reef. Atoll Research Bulletin 427, 1-35. 
Woodroffe, C. D., Kennedy, D. M., Hopley, D., Rasmussen, C. E., Smithers, S. G., 2000. Holocene reef growth in Torres Strait. Marine Geology 170, 331-346.

Woodroffe, S. A., 2009. Testing models of mid to late Holocene sea-level change, North Queensland, Australia. Quaternary Science Reviews 28, 2474-2488.

Wooller, M. J., Behling, H., Guerrero, J. L., Jantz, N., Zweigert, M. E., 2009. Late Holocene hydrologic and vegetation changes at Turneffe Atoll, Belize, compared with records from mainland Central America and Mexico. Palaios 24, 650-656. 



\title{
ATTAINABLE STANDARDS OF ACCURACY IN THE DETERMINATION OF HOLOCENE SEA LEVELS IN THE CENTRAL PACIFIC: INTRODUCTORY NOTE
}

\author{
TOM SPENCER ${ }^{1}$ and SARAH M. HAMYLTON ${ }^{2}$
}

The research underpinning Stoddart and Murphy's paper 'Attainable standards of accuracy in the determination of Holocene sea-levels in the Central Pacific' was undertaken in 1990-1993. This was a time when topographic survey was on the cusp of moving from traditional ground-based levelling surveys, from fixed, sea level-related benchmarks, to methods based on satellite altimetry. The former approach required surveys to be related to a well-defined tidal record (as detailed by Stoddart, 1978), while the latter effectively removed the need for a local datum by providing a common, global reference point, essentially the centre of the earth. As Stoddart and Murphy themselves perceptively noted 'New mobile global positioning systems (GPS) and satellite altimetry surveys hold out the prospect of relatively high accuracy surveying even on remote islands'.

In particular, the developments of differential GPS (dGPS) and Real Time Kinematic (RTK) technologies now offer the prospect of sub-meter and centimeter three dimensional co-ordinate quality respectively for coastal zone and shallow marine field survey (Hamylton, 2017). Such positioning methods, including elevation determinations, are now starting to appear in coral reef research outputs (e.g. Leon et al., 2013; Harris et al., 2014; Lowe et al., 2015; Morgan et al., 2017). Furthermore, there have been applications to the kinds of questions raised by Stoddart and Murphy on Moorea - as, for example, in the combination of RTK base station and traditional semi-automatic levelling to establish high resolution elevations related to lowest astronomical tide (LAT) for core locations, micro-atoll surfaces and island topographies at Pipon Island, northern Great Barrier Reef (Perry et al., 2017). In a few cases, such approaches have resulted in high resolution maps of entire reef systems, such as in the remarkable $1 \mathrm{~m}$ topo-bathymetric DEM for Majuro Atoll, Marshall Islands (Palaseanu-Lovejoy et al., 2017; part of the USGS Coastal National Elevation Database (CoNED) Applications Project (Danielson et al., 2016)).

The application of LiDAR and drone technology is also becoming increasingly widespread on coral reefs with the associated generation of high resolution $(<1 \mathrm{~m})$ digital elevation models that yield accurate relative elevations using remote sensing and photogrammetric techniques (Goodman et al., 2013; Casella et al., 2017). Nevertheless, such methodologies ultimately rely on a constellation of earth-orbiting satellites to establish absolute ground position by trilateration. GPS signals are prone to error from a variety of sources, including ephemeral deviations in the satellite orbits, atmospheric signal distortions, the sub-optimal geometric alignment of the satellites, multipath signals reflection and 'selective availability', that is, the historical degradation of signals for military purposes (prior to May 2000). Attaining a signal to correct these errors in real time through an intermediate base station may not always be possible at remote atoll locations. And, as Woodroffe et al. (2012) have shown, over long distances $(40 \mathrm{~km})$ on large oceanic atolls, satellite-based survey becomes affected by the Earth's geoid; thus on Christmas (Kiritimati) Island, Line Islands, a ca. $1 \mathrm{~m}$ elevation variation is apparent in the surface height of both living and fossil micro-atolls around the island's perimeter whereas locally differences are only of the order of $0.1 \mathrm{~m}$ (Woodroffe et al., 2012).

Thus whilst methodologies may change, the basic tenets of Stoddart and Murphy's paper, that meaningful height determinations on reefs can only be achieved by linking all measurements as precisely as possible to a well-defined datum, and that interpretation must be couched within a strong understanding of local environmental setting, and location-specific error terms, remain as relevant today as they did in on the motus of the Society Islands and the Tuamotu Archipelago over 25 years ago.

\footnotetext{
${ }^{1}$ Cambridge Coastal Research Unit, Department of Geography, University of Cambridge, Downing Place, Cambridge CB2 3EN, U.K.

${ }^{2}$ School of Earth and Environmental Sciences, University of Wollongong, Wollongong, New South Wales, Australia 2522.
} 


\section{REFERENCES}

Casella E., Collin A., Harris D., Ferse S., Bejarano S., Parravicini V., Hench J. L., Rovere A. 2017. Mapping coral reefs using consumer-grade drones and structure from motion photogrammetry techniques. Coral Reefs 36, 269-275.

Danielson J. J., Poppenga S. K., Brock J. C., Evans G. A., Tyler D. J., Gesch D. B., Thatcher C. A., Barras J. A. 2016. Topobathymetric elevation model development using a new methodology: Coastal National Elevation Database. Journal of Coastal Research 76, 75-89.

Goodman J. A., Purkis S., Shinn S. R. 2013. Coral reef remote sensing: A guide for mapping, monitoring and management. Dordrecht: Springer, $436 \mathrm{pp}$.

Hamylton S. 2017. Spatial analysis of coastal environments. Cambridge: Cambridge University Press, $x$ $+290 \mathrm{pp}$.

Harris D. L., Vila-Concejo A., Webster J. M. 2014. Geomorphology and sediment transport on a submerged back-reef sand apron: One Tree Reef, Great Barrier Reef. Geomorphology, 222, 132142.

Leon J. X., Phinn S. R., Hamylton S., Saunders M. 2013. Filling the 'white ribbon' - A seamless multisource Digital Elevation/Depth Model for Lizard Island, northern Great Barrier Reef. International Journal of Remote Sensing 34, 6337-6354.

Lowe R. J., Leon A. S., Symonds G., Falter J. L., Gruber R. 2015. The intertidal hydraulics of tidedominated reef platforms, Journal Geophysical Research C: Oceans 120, 4845-4868.

Morgan K. M., Perry C. T., Smithers S. G., Johnson J. A., Daniell J. J. 2016. Evidence of extensive reef development and high coral cover in nearshore environments: Implications for understanding coral adaptation in turbid settings: Scientific Reports 6, 29616, doi: 10. 1038 /srep29616.

Palaseanu-Lovejoy M., Poppenga S. K., Danielson J. J., Tyler D. J., Gesch D. B., Kottermair M., Jalandoni A., Carlson E., Thatcher C., Barbee M. 2017. One meter topobathymetric Digital Elevation Model for Majuro Atoll, Republic of the Marshall Islands, 1944 to 2016. U.S. Geological Survey data release (https://www.sciencebase.gov/catalog/item/ 59557881 e4b04e08be532c9a).

Perry C. T., Kench P. S., Smithers S. G., Riegl B. R., Gulliver P., Daniells J. J. 2017. Terrigenous sediment-dominated reef platform infilling: an unexpected precursor to reef island formation and a test of the reef platform size island age model in the Pacific. Coral Reefs 36, 1013-1021.

Stoddart D. R. 1978. Mapping reefs and islands. In: Stoddart DR, Johannes RE (eds.) Coral Reefs: Research Methods. Paris: UNESCO, 17-22.

Woodroffe C. D., McGregor H. V., Lambeck K., Smithers S., Fink D. 2012. Mid-Pacific microatolls record sea-level stability over the past 5000 yr. Geology 40, 951-954. 


\title{
ATTAINABLE STANDARDS OF ACCURACY IN THE DETERMINATION OF HOLOCENE SEA LEVELS IN THE CENTRAL PACIFIC
}

\author{
DAVID R. STODDART ${ }^{1}$ and FRANCIS J. MURPHY ${ }^{1,2}$
}

\begin{abstract}
Recent studies of Holocene sea-levels in French Polynesia show a general high stand of the sea at +0 .8-1.0 m between 5000 and $1000 \mathrm{yr}$ BP. Individual reef records which depart from this general curve are used to infer local uplift or subsidence (Pirazzoli and Montaggioni, 1988). Sea-level curves are based on radiocarbon-dated samples whose present elevation with respect to mean sea-level is estimated to the nearest 10 or $5 \mathrm{~cm}$; the height relation of these samples to modern analogues is then used to estimate a paleosealevel for each sample, also to 10 or $5 \mathrm{~cm}$ resolution. Tide predictions are however available only for certain stations to the nearest $10 \mathrm{~cm}$ at hourly intervals and must be extrapolated to other localities. Interpolation in the tidal cycle is made difficult by the local characteristics of the tides, and by storms, periodic ENSO oscillations and seasonal variability in sea-level, each of which may involve at least a decimeter error. Determination of a still-water level in reef situations is extremely difficult because of waves, swell, wave set-up, and pronounced local water surface slopes associated with currents, as well as ponding and evaporation. The determination of local still-water level is probably considerably less accurate than the $10 \mathrm{~cm}$ precision of tide predictions. Determination of sample elevations should be done instrumentally and related to local instrumentally - determined tidal conditions, especially in microtidal situations where the cumulative error is likely to be a substantial proportion of the historic variation in sea-level. There are also problems in the interpretation of materials used as Holocene sea-level markers, notably conglomerate platforms and beachrock. It is hazardous to use non-instrumentally determined elevation data to define Holocene sea-level curves in microtidal situations with large potential error terms, and then to use such curves to infer local rates of elevation and subsidence as small as $0.1 \mathrm{~mm} \mathrm{yr}-^{1}$.
\end{abstract}

\section{INTRODUCTION}

In a major series of papers since 1984, P. A. Pirazzoli, L. F. Montaggioni and colleagues have adduced evidence from reef environments in the Societies, Tuamotu, Australs and Gambiers for a widespread Holocene high stand of the sea in French Polynesia. They have produced radiocarboncalibrated sea-level curves for many islands and atolls suggesting a high stand of the sea of +0.8 to +1.0 $\mathrm{m}$ between 5000 and $1250 \mathrm{yr}$ BP. These reconstructions depend largely on the interpretation of corals and other organisms in the position of growth above their present life positions, of conglomerate platforms and their cements, of 'raised' beachrock and algal ridges, and of emerged tidal notches. Inferred Holocene sea-levels are quoted with a general vertical resolution of $10 \mathrm{~cm}$ and in a number of cases of $5 \mathrm{~cm}$ (Montaggioni and Pirazzoli, 1984; Montaggioni, 1985; Pirazzoli, 1985; Pirazzoli et al., 1985, 1988; Pirazzoli and Montaggioni, 1984, 1988).

We here discuss the question of attainable standards of accuracy in the reconstruction of Holocene sea-levels in French Polynesia, based on detailed studies on Moorea, Society Islands, and more extended observations elsewhere in the Societies and in the Tuamotu, Australs and Cooks. We concentrate on recent work in French Polynesia because it is the most sustained and systematic recent attempt to work out Holocene sea-level history in reef situations, with the results showing an apparent

\footnotetext{
${ }^{1}$ Department of Geography, University of California at Berkeley, Berkeley, California 94720, USA

${ }^{2}$ Gump Biological Research Station, University of California at Berkeley, BP 244, Temau, Moorea, French Polynesia.
} 
high degree of regional coherence. Our critique also applies to such previous studies as those on the northern Great Barrier Reef (McLean et al., 1978) and in the adjacent Cook Islands (Woodroffe et al., 1990).

\section{Location and Methods}

Moorea $\left(17^{\circ} 30^{\prime} \mathrm{S}, 149^{\circ} 50^{\prime} \mathrm{W}\right)$ is a barrier-reef encircled high volcanic island $15 \mathrm{~km}$ northwest of Tahiti, Society Islands (Galzin and Pointier, 1985). There are five reef islands (motu) on Moorea ranging in area from 0.7 to 159 ha (Figure 1). The largest (Temae) is now connected to the main island, the lagoon having been partially infilled following Polynesian occupation (Parkes and Flenley, 1990). Sea-level related research has been reported from here since Chevalier (1973). Pirazzoli and Montaggioni worked at Moorea between 1980 and 1985, and a study of the beachrock at Temae was reported by Bernier et al. (1990). Our own fieldwork has been conducted during 1990-1993. We have surveyed each motu using a Topcon electronic distance measuring total station. This instrument measures distances to an accuracy of $5 \mathrm{~mm}$ over $2 \mathrm{~km}$. We have determined that errors in elevations surveyed on the motu average $\pm 1 \mathrm{~cm}$ with a range of \pm 0.8 to $\pm 1.2 \mathrm{~cm}$. Thirteen hundred survey points have been determined on the conglomerate platforms of the motu and related to the Moorea topographic benchmark system (see below), in which elevations are determined to an accuracy of $1 \mathrm{~mm}$.

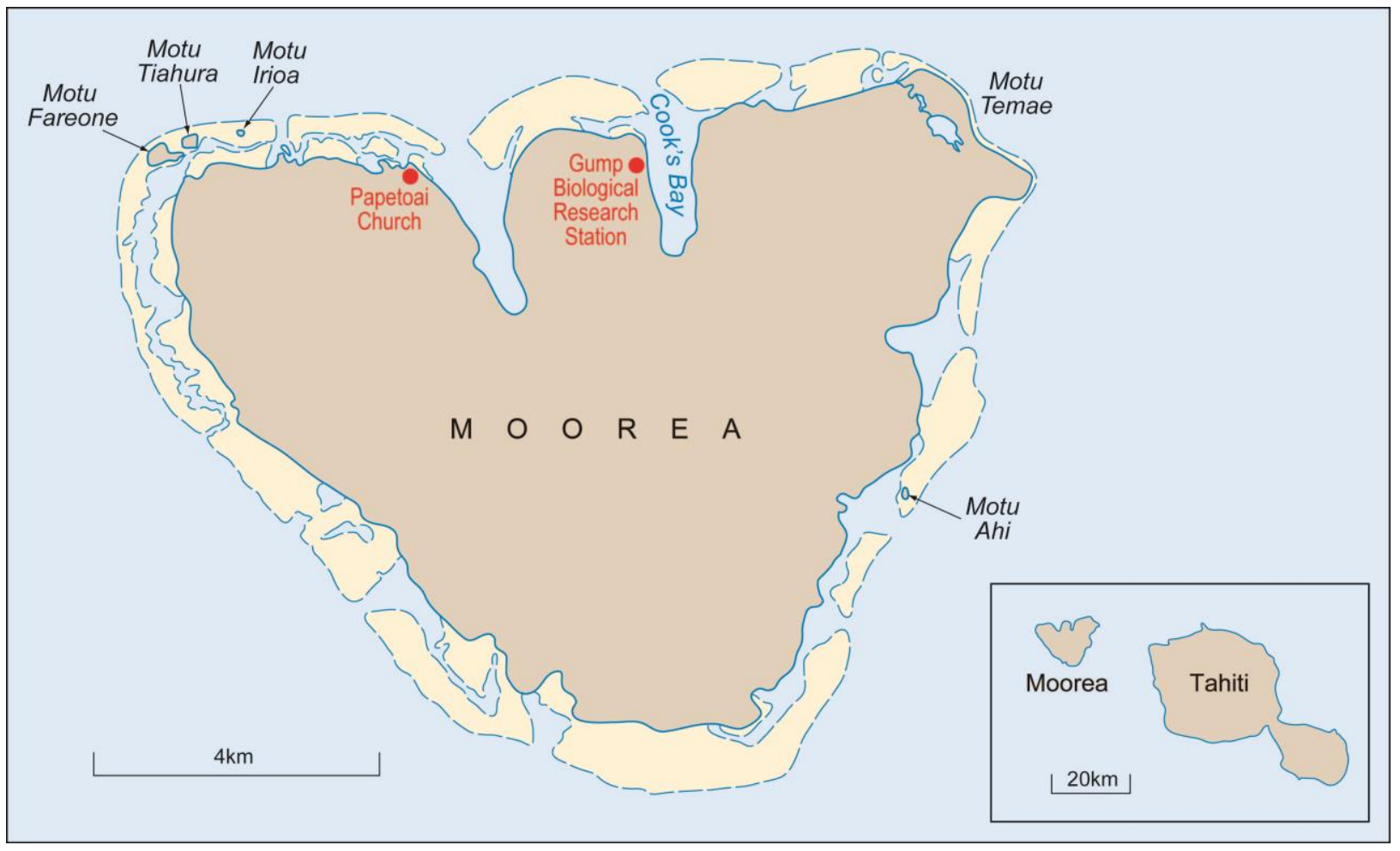

Figure 1. The island of Moorea located $\sim 15 \mathrm{~km}$ northwest of Tahiti in the Society Island, French Polynesia and showing the position of the five reef islands described in this paper. 


\section{THE PROBLEM OF DATUM}

There is no question that the problems of establishing an acceptable tidal datum in reef localities to which the elevations of sea-level indicators can be related and compared are severe. Tidal stations are maintained at Papeete and Mataiva on Tahiti, but published tidal predictions and corrections for French Polynesia derive from standard stations at Apia, Samoa, and Balikpapan, Borneo, and are given hourly to the nearest decimeter. It is common practice on reefs to attempt to estimate the height of a tidal datumPirazzoli and Montaggioni reduce all determinations to mean sea level (MSL) — by referring to such predictions, interpolating one or more local still-water levels on the predicted tidal curve, and then inferring the tidal datums. For present directly observable water levels under optimum conditions and with all other errors reduced to zero, this procedure can clearly only be accurate to the $10 \mathrm{~cm}$ accuracy of the tidal prediction itself.

Other error terms must certainly be included, however. First, there is an unknown error in extrapolating from the port for which the prediction is available (Papeete and Mataiva in the case of the Societies and Mururoa in the case of the Tuamotu) to the locality where tidal datum needs to be established: both phase and amplitude of the tide may differ between the two. These differences will not be significant between islands as close as Tahiti and Moorea, but will certainly be so over the extent of French Polynesia. Best estimates based on local knowledge can help minimise these effects, but there can well be an inevitable error of several centimeters involved in the method.

The problem is compounded by the nature of the tidal cycle in the Society Islands, the peculiarity of which has been recognised since the time of Cook in 1772. The tides are semi-diurnal, with minor diurnal inequality. Because of proximity to a lunar amphidromic point northeast of the Societies, the time of low water is rather loosely tied to 0600 and 1800 hours and of high water to 0000 and 1200 hours, rather than being progressive. The tidal signal is strong and clear during springs, but weak and irregular during neaps. It is also at the time of weak and confused neap tidal signals that water levels are most likely to be disturbed by meteorological effects. In our view it is not possible to extrapolate a tidal datum from predictions during the 5-6 days per month of neap tides with an error of less than $10 \mathrm{~cm}$ in places such as the Society Islands. This factor is nowhere mentioned in the literature.

Throughout Polynesia tidal range is small (everywhere less than $1.0 \mathrm{~m}$ and often as low as $0.3 \mathrm{~m}$ ): estimates of Holocene higher sea levels by previous workers in the area are of the same order of magnitude. It is therefore important to be able to specify with precision the amplitude of present tidal ranges. Montaggioni and Pirazzoli (1984, p. 35) and Pirazzoli et al. (1988, p. 60) quote ranges ('LST' to 'HST') for various locations only to the nearest decimetre: Moorea $0.3 \mathrm{~m}$; Hereheretue and Nukutipipi 0.5 $\mathrm{m}$; Rangiroa, Faaite, Apataki and Arutua $0.6 \mathrm{~m}$; and several other atolls in the eastern Tuamotu $0.7 \mathrm{~m}$ (see Figure 2 for the location of these and other islands mentioned in the text). We do not know of instrumental records of tides on Tuamotu atolls other than Mururoa, but on the basis of our own limited data we believe the absolute tidal range at Moorea to be closer to $0.4 \mathrm{~m}$ than $1.3 \mathrm{~m}$. Decimeter differences in tidal range are significant when postulating higher sea-level stands in the decimetre range.

Meteorological effects on water levels, while not yet fully analysed, are undoubtedly considerable. These operate on a variety of temporal scales:

(a) Individual storm events such as mara'amu southerlies, which have the effect depending on location of suppressing, enhancing or delaying tides. Thus on 2-3 July 1993 wind speed at Cook's Bay, Moorea, averaged $38.5 \mathrm{~km} \mathrm{hr}^{-1}$ with hourly maxima exceeding $50 \mathrm{~km} \mathrm{hr}^{-1}$ for 15 consecutive hours. Effects of such winds are particularly marked in microtidal situations and in areas where topography is a constraining factor;

(b) Seasonal variability in mean monthly sea level. Wyrtki and Leslie (1980) have shown that at Papeete and Mataiva, Tahiti, this is of the order of $7 \mathrm{~cm}$ mean monthly sea level, being highest in April and May and lowest in November and December; and

(c) More pronounced oscillations associated with periodic ENSO events. At open-ocean 
equatorial stations such as Fanning Atoll, Line Islands, these reached $45 \mathrm{~cm}$ between August 1982 and March 1983 (Wyrtki 1983).

Hurricanes and associated storm surges, while more dramatic disturbers of sea-level, can be discounted in the present context since no-one will choose to determine a tidal datum in such circumstances.

On the local level perhaps even more important than these quasi-periodic perturbations is the sheer difficulty of determining a still-water level in reef situations. Because of surf and wave set-up we do not believe that this can be done by estimation at the reef edge with any better accuracy than several decimeters: ind eed we defy anyone who has stood on an algal ridge, even at low tide, to convince us otherwise. Furthermore, because of frictional retardation within back-reef lagoons as well as wave set-up on reef edges there is frequently a conspicuous difference between open-ocean and immediate back-reef water levels. Pirazzoli (1985, figs. 22 and 23) has illustrated such a case from the northeast motu of Bora Bora, which we have seen, where there is a vertical difference in elevation of at least $50 \mathrm{~cm}$ between two horizontal sheets of water, one on the reef flat and the other in the immediate back-reef lagoon.

It must also be stressed that in high-energy situations such as trade wind reef areas, with unidirectional winds blowing with great constancy at velocities of over $10 \mathrm{~m} \mathrm{sec}^{-1}$ the local sea surface itself has an impressive geometry. Thus, in northwest Moorea, using field observations by Lenhardt (1991), Wolanski et al. (1993) have calculated water surface slopes of the order of 1:500-1:1000 over distances as small as 150 meters, yielding absolute variations in water surface elevations of up to 20 $\mathrm{cm}$. Similar water surface slopes are found at passes through barrier and atoll reefs where in some cases tidal currents in excess of $6 \mathrm{~m} \mathrm{sec}^{-1}$ have been recorded in macrotidal situations. It has also been recorded that heavy swells from the south and southwest during March to July can raise water levels in lagoons of open Tuamotu atolls, giving hi gher levels on their leeward sides and lower levels to windward (Pirazzoli and Montaggioni 1986, p.351; Pirazzoli et al., 1988, p. 59).

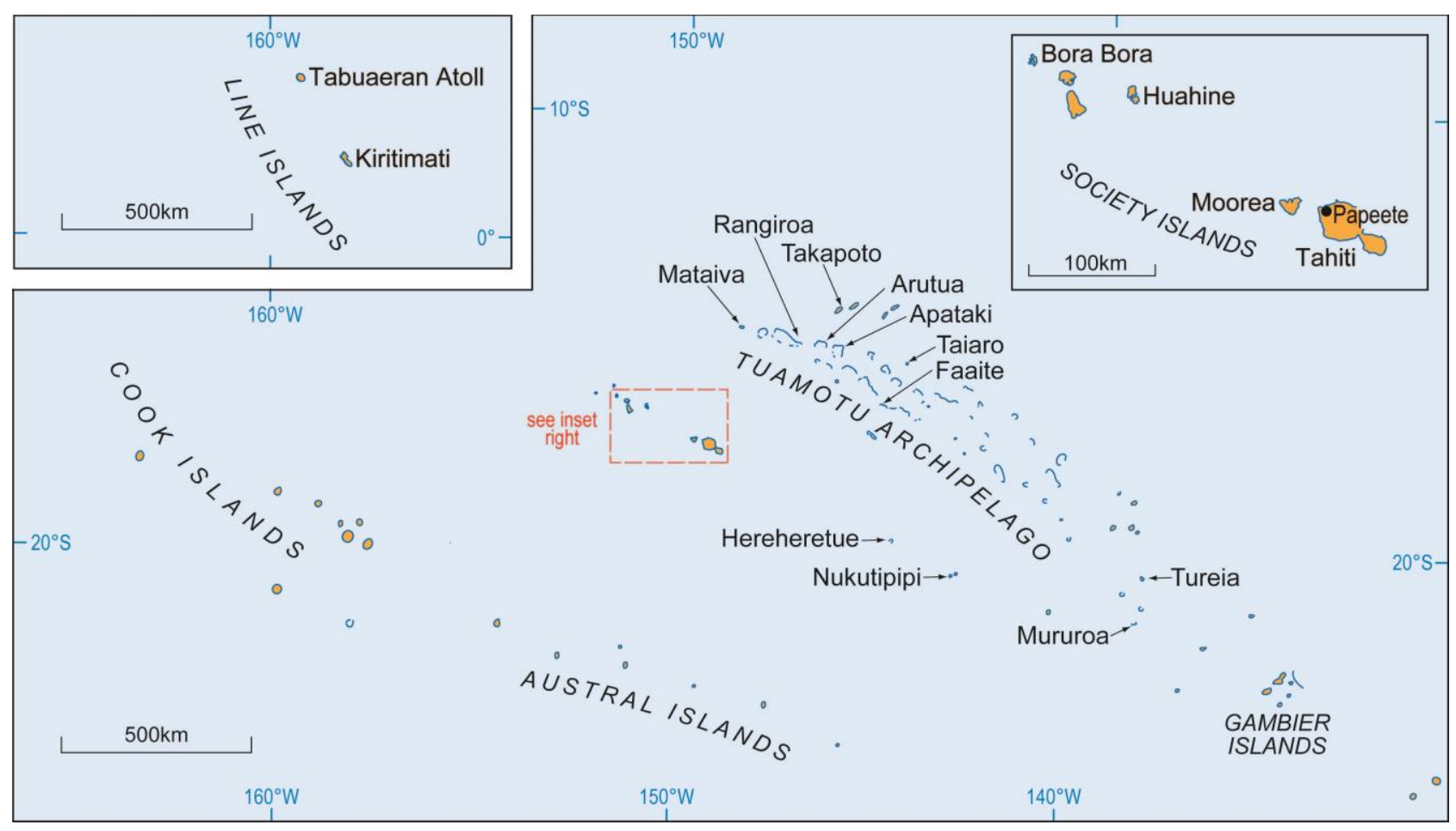

Figure 2. Island groups and individual islands and atolls mentioned in text. 
A number of Tuamotu atolls studied by Pirazzoli and colleagues have restricted lagoonal access to the sea. In such cases they consider that evaporation may lower lagoon water levels by as much as 'a few decimeters' (Pirazzoli and Montaggioni, 1986, p. 351). This effect is noted for Mataiva and Takapoto in the northwest Tuamotu and for eight out of twelve atolls studied in the central and eastern Tuamotu (Pirazzoli et al., 1988). The former paper makes clear which sample elevations are related to an inferred MSL and which to a lagoon water level where 'the precise relation to MSL is unknown'; in the latter all elevations are related to MSL, though a case is noted at Tureia where lagoon levels differed by $0.15-0.55$ $\mathrm{m}$ from the ocean level (Pirazzoli et al., 1988, p. 60).

In the first of these papers (Pirazzoli and Montaggioni, 1986) 29 sample elevations are listed from six atolls, of which 8 are to $5 \mathrm{~cm}$ resolution with no error term given. In the second paper (Pirazzoli et al., 1988) 41 elevations are quoted of which 19 are to $5 \mathrm{~cm}$ resolution, mostly with a stated uncertainty of \pm 10 $\mathrm{cm}$ but in a few cases \pm 20 or $30 \mathrm{~cm}$. All these elevations are with respect to MSL. They are then converted to 'paleo-MSL' by estimation of the original relationship of a sample to MSL at the time of its growth or formation. In most cases this involves adding $0.2-0.35 \mathrm{~m}$ to the sample elevation. Inthe second paper 13 of the 39 paleo-MSLdeterminations quoted are to $5 \mathrm{~cm}$ resolution, with error terms of $\pm 0-1-0.2 \mathrm{~m}$ in nine cases and $\pm 0.25-0.30 \mathrm{~m}$ in four cases. We quote these figures at some length to illustrate the level of precision claimed in these sea-level reconstructions.

We believe, however, that cumulatively the sources of error we have described in (a) determining a tidal datum and (b) establishing a tidally-meaningful still-water level in a reef situation, necessarily introduce substantial uncertainty into the non -instrumental specification of any tidal or sample elevation. Indeed, without an instrumentally determined tidal reference datum we do not think it feasible to attempt to specify present water levels to a standard approaching the decimeter precision of tidal predictions. It follows that we are equally sceptical of the possibility of specifying Holocene sea levels to a precision of 5 or $10 \mathrm{~cm}$.

This conclusion is not especially new, but it remains largely unrecognised and indeed ignored in reef situations: it is easier to produce a crisp sea-level curve which can be widely reproduced and compared with other similar curves, than to detail the uncertainties inherent in its construction. Thus on the reef islands of the northern Great Barrier Reef in 1973, all elevations were related to a common datum of mean lower low water springs based on predicted tides at Cairns. Surveyed elevations on individual reefs were regarded as relatively accurate to within a few centimeters, but it was realistic to recognize, after assessing the error terms, that between reefs there could be absolute discrepancies in such a macrotidal situation of up to 0.5 meters, and that absolute levels in relation to the Cairns datum could be in error by an equivalent amount. It was therefore considered inadvisable in that study to construct a conventional height-age sea-level curve, even though the analytical error on ages was comparatively small (McLean et al., 1978, p. 168-172). This reticence has not been common in subsequent sea-level studies in reef areas.

Pirazzoli and Montaggioni (1988, p. 159) and Pirazzoli et al., (1988, p. 60)allude to many of these problems in describing their field procedures. In some reports they introduce an error term on height determinations as well as citing the analytical error on radiocarbon dates, but it is clear from their specification of 5 and $10 \mathrm{~cm}$ precision in both MSL and paleo-MSL determinations that they consider the problems comparatively minor. They describe their field method as follows:

'Altitudes have been measured by means of a spirit level and a folding ruler, in relation to the water level estimated at the seaward reef margins, corrected with regard to the tide predicted at the nearest localities (SHOM, 1980-1985) and, when possible, to the local monthly sea level anomaly determined by Wyrtki and Nalcahara (1984) and by Wyrtki (1984-1985). Anomalous meteorological conditions which may have affected the local sea-level position were noted systematically. When altitude measurements had to be carried out in relation to the water level in the lagoon or in ponds, the accuracy of the measurements has been estimated in each case. If not otherwise stated all elevations are related to MSL' (Pirazzoli and Montaggioni, 1988, p. 159). 
We believe, however, that the only way to avoid the cumulative errors in height determination on reefs which we have described is to link all measurements as precisely as possible to an instrumentallydetermined tidal datum. We also believe that where possible this should become standard procedure in the reef seas. In our own work on Moorea all elevations are referred to benchmarks established at $1.0 \mathrm{~km}$ intervals around the perimeter of the island in 1981. The elevations of these are related to MSL, estimated to be $0.34 \mathrm{~m}$ above hydrographic datum determined at Papetoai by tide-gauge observation, 15 July 197030 April 1971. The fundamental island benchmark adjacent to the tide gauge site, on the church at Papetoai, has a height of $1.030 \mathrm{~m}$ above MSL. Derivative benchmarks around the island have elevations quoted to the nearest millimetre (Coulon and Teauna, 1981). There is of course some uncertainty in the transfer of datum from the tidal record to the topographic datum. The benchmarks themselves are ageing, some have disappeared, and some have been displaced. It has not always been easy to reconcile our own surveys with benchmark elevations. They are nevertheless the best standard available for the determination of present and former sea-levels on reefs and reef islands where they have been established.

The requirement of using an instrumentally-determined tidal datum either restricts sea-level studies to islands where such a datum exists, or means that the study should be of sufficient length and precision for such a datum to be instrumentally developed. New mobile global positioning systems (GPS) and satellite altimetry surveys hold out the prospect of relatively high accuracy surveying even on remote islands, however.

\section{SIGNIFICANCE OF SEA LEVEL EVIDENCE}

Uncertainties on determinations of elevations in areas such as Moorea are at least quantifiable: the paleosea-level significance of the samples dated may be more enigmatic. In order for reef and reef island features to be used as sea-level markers we must understand their formative history in relation to sea-level. In order to accomplish this, unambiguous contemporary analogues must be found and the processes controlling their elevation with respect to tidal datums must be understood: the elevational interpretation of sea-level markers is especially important in microtidal areas. The interpretation of an ancient feature as a sea-level marker without strong evidence linking its morphogenesis with sea-level can only result in a weak conclusion.

Even while using sea-level markers that are well understood, arguments for former sea-level stands should not be based solely on one or two types of markers. In places in the reef seas where there have been clear sea-level changes there are usually several types of markers (raised algal ridges, raised microatolls, raised beachrock, raised in situ reef framework, raised intertidal notches) that can be used for corroboration. In places where only one or two types of marker are found the absence of others where they might be expected requires explanation.

Two main groups of marker have been used by Pirazzoli and his colleagues in French Polynesia. Pirazzoli and Montaggioni (1988) list 153 samples with elevational data bearing on sea-level history. Of these, 77 are of corals, molluscs, algal crust, algal ridge, and in situ reef framework, and 54 of these are from the Tuamotu. Sixty-three samples are of reef conglomerate and raised beachrock, and of these 27 are from the Societies and 28 from the Tuamotu.

We discuss the evidence of three common sea-level markers used in French Polynesia with particular reference to observations on Moorea.

\section{Corals and Other Organisms in Growth Position and In Situ Reef Framework}

While impressive suites of fossil microatolls are found in the Leeward Society Islands and similar and related features in the Tuamotu, no such materials are found anywhere on Moorea. We find it surprising that if Holocene sea-level did indeed stand $1 \mathrm{~m}$ higher than at present for several thousand years prior to $1000 \mathrm{yr} \mathrm{BP}$, this is nowhere reflected in reef constructional or growth features. The 
presence of such features as microatolls by no means presents an unambiguous sea-level signal (Scoffin and Stoddart, 1978), but their complete absence is difficult to explain.

\section{Conglomerate Platforms}

On Moorea, as elsewhere in French Polynesia, these are lithified poorly-sorted bioclastic deposits on the seaward sides of or close to reef-top islands. We agree with Pirazzoli and Montaggioni that they originated as episodic storm deposits that were subsequently cemented. They are characterised by quasihorizontal upper surfaces. Pirazzoli and Montaggioni believe this to be an original depositional topography, but we do not know of comparable contemporary rubble deposits on Moorea or elsewhere with similar topography.

Montaggioni and Pirazzoli $(1984,30)$ state that 'as the altimetrical position of the top of the conglomerate platform outcrops results from storms or other catastrophic events, it cannot be considered to have a precise eustatic significance.' However, they believe on the basis of internal carbonate cements that they can determine former marine water tables (i.e. the boundary between marine phreatic and vadose processes) and hence paleosealevels to within 10 and even $5 \mathrm{~cm}$. Since it is not possible to establish modern sea-levels to this precision we find it difficult to accept this claim.

There is reason however to further question the accuracy of this method of determining paleosealevels. First, in places where the boundary between phreatic/vadose and vadose cementation is within $5 \mathrm{~cm}$ the samples in the case of Moorea derive from different motu. These motu are separated by 7 $\mathrm{km}$ and their seaward shores (and hence platforms) face different directions and thus experience quite different wind and wave regimes. Further, in a paper describing the value of marine diagenetic boundaries as sea-level markers, Coudray and Montaggioni (1986, p. 313) state: 'The boundaries between major diagenetic zones need not exactly represent those of the corresponding tidal environments, since they might be held at some position above or below a particular tide level due to local hydrological circumstances.' These conditions appear incompatible with paleosealevel inference at $5 \mathrm{~cm}$ precision.

A major problem in the use of conglomerate platforms as sea-level markers is that there is no general agreement as to how they evolve in relation to sea-level. Montaggioni and Pirazzoli assume that they are depositional features of the kind described by Scoffin and McLean (1978); that they formed close to sea-level as boulder, rubble and gravel sheets; and that their horizontal upper surfaces are primary in origin. Scoffin and McLean however describe such primary depositional features as rising to $2 \mathrm{~m}$ above MSL, whereas Montaggioni and Pirazzoli hold that such present elevations can only result from a fall in sea-level since their formation. Moreover, if conglomerate platforms did originate as boulder, rubble and gravel sheets in the intertidal, and their surfaces were primary in origin, one would expect at least some sorting of component clasts by wave action, and this is not found.

An alternative hypothesis is that the platforms are the result of the basal cementation of large boulder, rubble and gravel banks. Both the height and the horizontal nature of the surface would be controlled by capillary head created in the interstitial pore space within the bank. Coudray and Montaggioni (1986, p. 313) state that 'the upper limits of the marine phreatic zone may be locally raised slightly above the mean low-tide level (effects of capillarity or intergranular tension).' Vadose cementation would be expected to occur at higher levels, and uncemented materials above would eventually be removed by subsequent storms. As the surface of the new platform was exposed the capillary head would subside and a second generation of vadose cements would overly the higher level phreatic cements. This process would result in a pattern of diagenesis similar to that observed by Montaggioni and Pirazzoli (1984) throughout French Polynesia, without the need to infer a fall in sealevel. The huge boulder/rubble storm bank created by Tropical Cyclone Bebe on Funafuti in 1972 has been monitored (Baines and McLean, 1976), and Richmond (1992) has noted recent basal cementation and postulated that this may result in a modern analogue for conglomerate platform formation. The remarkable horizontality of the upper surface of the conglomerate platforms is problematic. As we have noted, Montaggioni and Pirazzoli believe it to be an original depositional feature. Field observation indicates, however, that the upper surface is frequently composed of cemented cover sands that blanket a 
more irregular topography.

The highest elevations on the Moorea platforms, reaching $1.4 \mathrm{~m}$ above MSL, are the tops of large boulders of Porites cemented onto or just below the surface. These, and also some Acropora colonies, were interpreted by Chevalier (1973) as being in growth position. They are, however, distinctly clustered on the platforms at Motu Fareone, Tiahura and Temae, and suggest to us, as to Pira zzoli and Montaggioni, episodic storm depositional events without any specific sea-level significance.

\section{Beachrock}

Most of the beachrock on Moorea, both on the mainland shore and on the motu, is in the low intertidal and is clearly contemporary. Beachrock also occurs in characteristic suites of linear, seawarddipping ledges on the surfaces of the conglomerate platforms. At Temae the beachrock has a height range of +0.1 to +1.3 meters and a modal height of $+0.85-+90$ meters $(0.15 \mathrm{~m}$ higher than the modal height of the platform surface, based on 95 height determinations). We do not, however, believe that 'high' beachrock means 'raised' beachrock. At Temae and on the other motu the beaches landward of the conglomerate platforms, while well supratidal, are highly active and are routinely overwashed by waves. Reports from local residents and our own observations indicate that these beaches are active several times a year, when sand- and gravel-sized sediments are added both to the beach and to the conglomerate platform surface. Similar 'perched' beachrock at the southern end of the conglomerate platform at Motu Ahi is very clearly related to the migration of a mobile sand and shingle spit extending from the island. Where there is no platform, which is usually, but not always, in more protected situations, the beachrock on Moorea is intertidal. Indeed at Temae the 'raised' beachrock on the platform can be followed eastward along the shore until the platform disappears, by which point the beachrock has descended into the intertidal zone. It is apparently 'raised' only because it has in a number of sites a high-standing substrate on which sediment accumulates and beachrock forms.

There are no other features on Moorea, such as raised abrasion platforms or intertidal notches, indicative of Holocene higher sea-levels.

\section{Dating}

Given the uncertainties about determination of elevations and about the interpretation of shoreline deposits, dating is relatively unproblematic, given normal sample constraints. Radiocarbon dates are routinely stated with an analytical error of \pm 1 sigma. It is, however, well known that many factors affect the accuracy of radiocarbon dates, and that to plot them as points on sea-level curves irrespective of qualitative as well as quantitative uncertainty can be misleading.

In addition, corrections for isotopic fractionation have been made to some published dates. Thus 400 years have been deducted from four samples from Rangiroa (compare Pirazzoli, 1985 and Pirazzoli and Montaggioni, 1988), while a partial correction (because of a paleogeomorphic uncertainty) of 200 years has been made for samples from Takapoto and Taiaro (compare Chevalier and Salvat, 1976 and Pirazzoli and Montaggioni 1984, 1986, with Pirazzoli and Montaggioni, 1988). These corrections are made quite explicit, and confusion may only arise because of the sheer volume of dates reported and the numbers of papers in which they are published.

\section{CONCLUSION}

Shennan (1982) was among the first systematically to attempt to quantify uncertainties in Holocene sea-level reconstruction, though in a non-reef environment. Heyworth and Kidson (1982) introduced the concept of plotting paleo-sealevel data by ellipses, expressing degrees of uncertainty both in elevation and in age, rather than simply as points on a curvilinear graph. Kidson (1982) followed this with a most important paper on the problems of Holocene sea-level reconstruction, which broadly 
coincided with a general re-evaluation of the concept of eustasy. Kidson's examples were again not from the reef seas, but the issues which he raised are broadly those dealt with in this discussion.

More depends on the resolution of these issues than simply the determination of Holocene sea-

level history. On a longer time-scale the presence of Pleistocene and older reef limestones has been used to calibrate models of crustal history and structure (see Spencer et al., 1987 for discussion). Pirazzoli and Montaggioni (1985) use their early Holocene sea-level curves to speculate on lithospheric flexure in the general area of French Polynesia, and in a specific example Pirazzoli et al. (1988) suggest that Anaa Atoll, Tuamotu Archipelago is rising at the rate of $0.1 \mathrm{~mm} \mathrm{yr}^{-}{ }^{-}$. Elsewhere they also suggest, again from sea-level history reconstructions, that Tahiti is subsiding at the rate of 0.15 and Huahine and Moorea at $0.14 \mathrm{~mm} \mathrm{yr}^{-1}$ (Pirazzoli et al., 1985, p. 136; Pirazzoli and Montaggioni, 1985, p. 200, 1988, p. 169).

These are all very small rates with very substantial implications deduced from field data that we have shown to be beset with profound uncertainties. If such inferences are to be drawn we feel it necessary that sea-level reconstructions be precisely grounded in instrumental records of precise tidal behaviour; that sample elevations be instrumentally related to a determined tidal datum; and, that the interpretations be sensitive to the often profound ambiguities of the kinds of evidence available.

\section{REFERENCES}

Baines, G. B. K and R. F. McLean, 1976. Sequential studies of hurricane deposit evolution at Funafuti atoll. Marine Geology, 21:M1-M8.

Bernier, P., J. Bonvallot, R. Dalongeville and A. Prieur, 1990. Le beach-rock de Temae (Ille de Moorea Polynésie française): signification géomorphologique et processus diagénéiques. Zeitschrift fur Geomorphologie, 34, 4:435-450.

Chevalier, J. P., 1973. Geomorphology and geology of coral reefs in French Polynesia. O. A. Jones and R. Endean (eds) Biology and Geology of Coral Reefs, New York, Academic Press, Geology 2:113-167.

Chevalier, J. P. and B. Salvat, 1976. Etude geomorphologique de l'atoll ferme de Taiaro. Cahiers du Pacifique, 19:169-201.

Coudrey, J. and L. Montaggioni, 1981. The diagenetic product of marine carbonates as sea level indicators. Sea-level Research: 311-360.

Galzin, R. and J. Pointer, 1985. Moorea Island, Society Archipelago. Proceedings Fifth International Coral Reef Congress, Tahiti, 1:73-102.

Heyworth, A. and C. Kidson, 1982. Sea-level changes in southwest England and Wales. Proceedings, Geological Association, 93, 1:91-111.

Kidson, C., 1982. Sea level changes in the Holocene. Quaternary Science Reviews, 1, 2:121-151.

Lenhardt, X., 1991. Hydrodynamique des lagons d'atoll et d'ile haute en Polynesie francaise. Editions de l'ORSTOM, Paris, 132 pp.

McLean, R. F., D. R. Stoddart, D. Hopley and H. Polach, 1978. Sea level change in the Holocene on the northern Great Barrier Reef. Philosophical Transactions of the Royal Society, London A, 291:167-186.

Montaggioni, L. F. and P. A. Pirazzoli, 1984. The significance of exposed coral conglomerates from French Polynesia (Pacific Ocean) as indicators of recent sea-level change. Coral Reefs, 3, 1:2942.

Parkes, A. and Flenley, J. R. 1990. The Hull University Moorea Expedition 1985. School of Geography and Earth Resources, Miscellaneous Series No 37, University of Hull, Hull, UK

Pirazzoli, P. A., 1985. Bathymetric mapping of coral reefs and atolls from satellite. Proceedings Fifth International Coral Reef Congress, Tahiti, 6:539-544.

Pirazzoli, P. A. and L. F Montaggioni, 1984. Variations récentes du niveau de l'océan et du bilan hydrologique dans l'atoll de Takapoto (Polynésie française) Comptes-rendus des séances de l'Académie des sciences. Série 2, 299,7:321-326. 
Pirazzoli, P. A. and L. F. Montaggioni, 1986. Late Holocene sea-level changes in the north-west Tuamotu Islands, French Polynesia. Quaternary Research, 25, 3:350-368.

Pirazzoli, P. A. and L. F. Montaggioni, 1988. Holocene sea-level changes in French Polynesia. Palaeogeography, Palaeoclimatology, Palaeoecology 68, 2-4:153-175.

Pirazzoli, P. A., L. F. Montaggioni, G. Delibries, G. Faure and B Salvat, 1985. Late Holocene sea level changes in the Society Islands and in the northwest Tuaislet Atoll. Proceedings Fifth International Coral Reef Congress, Tahiti, 3:131-136.

Pirazzoli, P. A., L. F. Montaggioni, B. Salvat and G Faure, 1988. Late Holocene sea level indicators from twelve atolls in the central and eastern Tuamotus (Pacific Ocean). Coral Reefs, 7, 2:57-68.

Richmond, B. M., 1992. Development of atoll islets in the Central Pacific. Proceedings Seventh International Coral Reef Symposium, Guam, 2:1185-1194.

Scoffin, T. and R. F. McLean, 1978. Exposed limestones of the northern province of the Great Barrier Reef. Philosophical Transactions of the Royal Society, London A, 291:119-138.

Scoffin, T. P. and D. R. Stoddart, 1978. The nature and significance of microatolls. Philosophical Transactions of the Royal Society, London B, 284:99-122.

Shennan, I. 1982. Interpretation of Flandrian sea level data from the Fenland, England. Proceedings. Geological Association, 63,1:53-63.

Spencer, T., D. R. Stoddart and C. D. Woodroffe, 1987. Island uplift and lithospheric flexure observations and cautions from the South Pacific. Zeitschrift fur Geomorpologie, NF, Suppl, 63:87-102.

Wolanski, E., B. Delesalle, V. Dufour and A. Aubanel, 1993. Modelling the fate of pollutants in the Tiahura Lagoon, Moorea, French Polynesia. $11^{\text {th }}$ Australasian Conference on Coastal and Ocean Engineering, Institution of Enginers, Australia, Townsville: 583-588.

Woodroffe, C. D., D. R. Stoddart, T. Spencer, T. P. Scoffin, A.W. Tudhope, 1990. Holocene emergence in the Cook Islands, South Pacific. Coral Reefs, 9, 1:31-39.

Wyrtki, K., 1983. Sea level in the equatorial Pacific in 1982. Tropical Ocean-Atmosphere, 16:6-7.

Wyrtki, K. and W. G. Leslie, 1980. Mean annual variation of sea level in the Pacific Ocean. Report HIG, 80-5 Hawaii Institute of Geophysics, University of Hawaii, Honolulu, Hawaii, USA. 


\title{
ALEXANDER AGASSIZ AND CORAL REEF CONTROVERSY: INTRODUCTORY NOTE
}

\author{
DAVID DOBBS ${ }^{1}$
}

Soon after I was foolish enough to decide I'd like to write a book about the strange, doomed, half-century-long argument that the zoologist and millionaire Alexander Agassiz chose to have with Charles Darwin about how coral reefs form, I was lucky enough to run into David Stoddart's wonderfully titled "Coral Reefs: The Last 2 Million Years." I'd never heard of Stoddart. (Like I said, it was early.) But in ten pages he became my friend, for in those pages he made clear that the Agassiz-Darwin argument over "the coral reef problem," as everyone called it in the 19th century, expressed not only two men's visions of coral reef formation but far deeper tensions in science about how to see the world, how to think, and how science would thenceforth be done. It was, in other words, that writer's dream: a rich vein that had not, at the popular level, been heavily mined.

The writer John McPhee says a story's opening must "shine like a flashlight" through the rest of the piece, showing the edges and silhouettes of its parts. Stoddart's work became the flashlight guiding me through my book. Again and again my searches (not on Google, but in the dusty stacks of Harvard's libraries) landed most productively on Stoddart's: superb, accessible, warmly literate papers on "the deductive method in coral reef studies, Darwin to Davis"; on "Darwin and the Seeing Eye: Iconography and Meaning in the Beagle Years"; on Lyell's influence on Darwin's view of reefs. Time and again Stoddart wove together data, history, theory, and (missing in far too many papers) the agendas and characters of the researchers to show not just how reefs form and accrue, but how ideas do. I quickly learned that a Stoddart paper was usually worth five from anywhere else.

As I recall now, 15 years later, it took me a while to gather courage to write him. When I did, I of course found a smart, funny, and supremely generous soul and supporter. With every reason to be leery of this unknown pop-sci writer or protective of his own lifetime of work, he shared his thoughts and papers and ideas. Among these was the extraordinary manuscript you find below: "Alexander Agassiz and Coral Reef Controversy".

Of this Agassiz paper in particular he had reason to be protective. Why would you provide a popsci writer writing a book an unpublished manuscript that represented years of your own work on the same subject? Yet he did. For me the paper proved invaluable. It covered much of the ground I'd covered in my book, allowing me to firm and correct my own account. It clarified and confirmed and enriched what I, a non-scientist, has concluded about the nature of Agassiz's failures. It was so good and so useful that for two reasons I was and remain glad that it came to me late in my work on my book: First, its late arrival meant that no one, most importantly me, would think I'd gotten my whole idea from him. Second, I fear now that had this paper come to me earlier I might have abandoned my book idea - for why write a book that in so many ways had already been written?

But this was the Stoddart I knew: A man who would encourage my venture, and then improve it yet further with his read of the manuscript. A man who served simultaneously as a guide, a model, and a motherlode of rich, rigorous scholarship. Most important to me, he was a scholar who never ignored that science is a wonderfully, messily human endeavour. In our efforts to reveal nature's secrets, we reveal

${ }^{1}$ David Dobbs, author of 'Reef Madness: Charles Darwin, Alexander Agassiz, and the Meaning of Coral,' (New York City: Pantheon, 2009) writes on science, nature, medicine, and culture for The New York Times, National Geographic, The Atlantic, and other publications. Links to his work can be found at daviddobbs.net. 
much about ourselves - far more than we usually realize at the time. In sharing with me his thorough, fascinating, sometimes biting account of Agassiz's coral work, he revealed not only Agassiz's flaws and failures, but his own generosity and character. They don't make many like him anymore. 


\title{
ALEXANDER AGASSIZ AND CORAL REEF CONTROVERSY
}

\author{
DAVID R STODDART ${ }^{1}$
}

\begin{abstract}
Perhaps no human being has ever seen more coral reefs and islands than Alexander Agassiz (18351910). Born as Darwin was drafting his theory of coral reefs as the Beagle sailed between Tahiti and New Zealand, Agassiz devoted much of his life and his great financial resources to criticizing that theory. He published (and financed) substantial descriptive monographs on the reefs of Florida, Cuba, the Bahamas, Bermuda, the Great Barrier Reef, the greater part of the tropical Pacific, and the Maldive Islands, yet his one summary paper presented only trivial conclusions. His field observations were frequently unreliable and his theoretical conclusions false. While he energized the Harvard Museum of Comparative Zoology, was widely honored by scientific academies in his lifetime, and knew many of the principal protagonists in the coral reef controversies of the late nineteenth century, his work on reefs is now totally forgotten. This paper examines the tragedy of the failure of Agassiz's coral reef research program, in the social and scientific context of his time.
\end{abstract}

\section{INTRODUCTION}

Perhaps no single person has ever seen more coral reefs and islands than Alexander Agassiz, and certainly no-one has exceeded his capacity for sumptuous and extensive publication about his expeditions. Yet his work was virtually rejected or ignored by those of his contemporaries who were actively engaged in reef studies and it is now totally forgotten: in spite of all his efforts he made no significant impact on coral reef science. This paradox raises questions about his style of science - the problems he studied, the observations he made, and the conclusions he reached - and they are questions which need to be posed in the context of a personal and professional life which is still inadequately understood.

Alexander was born in Switzerland in 1835, the only son of Louis Agassiz, destined to become one of the dominant figures of American natural science in the nineteenth century (Lurie, 1960). When Alexander was a small boy his mother died and his father moved to the United States, Alexander following in 1847 . He became a marine biologist, specializing in echinoderm taxonomy (Louis founded the Museum of Comparative Zoology at Harvard in 1860, and directing it and expanding its collections became one of the major works of Alexander's life). Like his father, however, Alexander could not accept Darwin's evolutionary views, as became apparent soon after the publication of On the Origin of Species in 1859. He met Darwin at Down in December 1869 when he was 34 and Darwin 60. The meeting was cordial (F. Darwin and Seward 1903, 2, 357-358). Darwin and Agassiz sent each other their publications and the two corresponded in a somewhat desultory way until Darwin's death in 1882 . But Agassiz's inability to subscribe to evolutionary ideas may have influenced the vehemence of his later rejection of Darwin's coral reef theory.

December 1873 represented a turning point in Agassiz's life. Louis Agassiz died, and then, unexpectedly, did Alexander's wife. He was later described as 'a saddened and an ill man' for the rest of his life (Mayer 1910b, 453). Increasingly he retreated into the planning and performance of major expeditions, at first purely oceanographic and then increasingly to do with coral reefs and islands. In 1873 also he had gone to Halifax, Nova Scotia, meeting Wyville Thomson and John Murray on board H.M.S. Challenger (having previously met Thomson in Belfast in 1869). This meeting established a warm relationship with Murray that lasted all Agassiz's life: the two came to reinforce each other in their

${ }^{1}$ Department of Geography, University of California at Berkeley, Berkeley, California 94720, USA 
antipathy to Darwin's views on coral reefs, though their own ideas on the subject were scarcely compatible. When the Challenger Expedition was over, in 1876, Agassiz visited Murray at his Edinburgh headquarters and cemented the friendship; he also reported on the Challenger echinoderm collections.

According to Murray's memoir of Agassiz, the latter's interest in coral reefs was first aroused during this visit, when Murray gave a paper on calcium carbonate deposits and reefs. In that paper Murray argued that all the characteristic features of atolls and barrier-reefs could be explained by a reference to the biological, mechanical, and chemical processes everywhere going on in the ocean without calling in the extensive subsidence demanded by the theories of Darwin and Dana. 'I never really accepted the theories of Darwin and Dana; it was all too mighty simple,' Murray recalls Agassiz saying on that occasion; 'besides, this new view [of Murray's] is founded on observation and can be verified, and I'll attempt to do it, and will visit coral reef regions for the purpose' (Murray, 1911:22-23). If Murray's recollection was correct, therefore, it would appear that Agassiz had fairly definite views on the coral reef problem before he began his own investigations.

His first expedition in 1874-1875 to Chile and Peru, including Lake Titicaca, proved something of an interlude, though he did find a fossil coral reef at an elevation of 1000 meters, $30 \mathrm{~km}$ inland (Agassiz, 1876; Walcott, 1912:35). But in 1877 he took the U.S. Coastal Survey steamer Blake on the first of three oceanographic cruises, during which he studied the Florida reefs (Agassiz, 1885, 1888) and achieved a sounding of $6.2 \mathrm{~km}$ (3400 fathoms) in the Bartlett Trough or Cayman Trench in the western Caribbean. By the end of the Blake explorations in the eastern Pacific, Agassiz was very definitely interested in 'the coral reef problem': for the next twenty years it provided the focus of his scientific life.

That he was able to develop this interest was entirely the result of his immense personal wealth. From 1867 onwards he had been involved in the development and management of the Calumet and Hecla copper mines on the south shore of Lake Superior. By the time of his death these had yielded a dividend of $\$ 110$ million. Agassiz was able to join that small group of wealthy men - people like Prince Albert of Monaco and J.Y. Buchanan - who chose to use their resources and social standing to further their oceanographic interests, in the days before institutional and national support was available for such ventures. He became a great philanthropist, donating \$1.5 million dollars to the Museum of Comparative Zoology, which in its turn published his voluminous reports (there were 170 plates in the Maldives paper, for example and 240 in that on the Pacific reefs). Largely at his own expense he cruised for more than 100,000 miles, mostly during the Boston winter, to see the reefs of the world. It is hardly surprising that he became somewhat autocratic - he looked like Bismarck, it was said, and sometimes acted like him — nor did the Museum resort to peer review for publications in its Bulletins and Memoirs.

\section{AGASSIZ'S CORAL REEF PROGRAMME}

Agassiz began his field study of reefs in Florida and the Dry Tortugas in March and April 1881, assisted by J. W. Fewkes: this resulted in his first paper specifically on reefs (Agassiz, 1885). Appropriately it was an area where his father had worked thirty years earlier, and in piam memoriam he reprinted his father's report with appropriate illustrations (L. Agassiz, 1852, 1880)

In 1885 Agassiz worked on reefs around Oahu, Maui and Hawaii, and in 1891 on those of the Galapagos and the eastern Pacific. But his major reef expeditions began the following year, with a study of the raised reefs of the Bahamas and Cuba in the steam yacht Wild Duck: for the first time on this expedition Alfred Goldsborough Mayer served as an assistant. In 1894 Agassiz carried out similarstudies in Bermuda.

In 1896 he was with Mayer in the steamer Croydon on the Great Barrier Reef, but the study was much hampered by rough weather and little was achieved. In 1897-1898 Agassiz traveled extensively in the Fiji Islands in the steamer Yaralla, later employing E. C. Andrews specifically to study the elevated reef limestones.

His two largest reef expeditions were his last. For nine months over the winter of 1899-1900 he 
traveled widely in the tropical Pacific in the U.S. Fish Commission steamer Albatross, again with Mayer, giving accounts of islands and reefs in the Marquesas, Tuamotus, Societies, Cooks, Fiji, Ellice, Gilberts, Marshalls, Carolines and Marianas. It was an astonishing expedition, enabling Agassiz (1903a) to write accounts of no less than thirty atolls in the Tuamotus (some of them never described before or since), nine in the Gilberts, nine in the Marshalls and ten in the Carolines, as well as many high reef-encircled islands. In 1901-1902, in the British India vessel Amra, he traveled some 1600 miles through the Maldive Archipelago in the central Indian Ocean, describing 25 atolls in less than thirty days (Agassiz, 1903b).

He had also had in mind a further expedition to the reefs of Southeast Asia, but in his report on the Maldives he stated that: 'This is the last of the series of monographs I shall publish on Coral Reefs, and I hope, as soon as practicable, to give a resume and connected account of the results obtained during my expeditions to all the important coral regions of the Atlantic, Pacific, and Indian Oceans' (Agassiz, 1903b:ix). Agassiz was then 67 years old.

It may be noted that Agassiz's most ambitious expeditions, to the tropical Pacific and the Maldives, came in his middle sixties, and that he was already well into middle age before he began serious reef studies. This factor alone must have constrained what he could do in the field, quite as much as his attitudes and presuppositions.

\section{THE REEF EXPEDITIONS}

It is not the purpose of this paper to summarize the itineraries and detail the results of each of Agassiz's reef expeditions: the expeditions were too numerous and prolonged and the reports too extensive for that to be possible. I wish rather to comment on each expedition with particular reference to the problems emphasized and the arguments advanced. No attempt is made to compare Agassiz's interpretations with the current state of knowledge of each area, though some reference is made to major advances, including the record of subsequent deep borings. In commenting on Agassiz's work I have concentrated on those areas where I have been able to compare Agassiz's field observations with my own. Thus, for example, in discussing the memoir on the tropical Pacific I have concentrated on the Tuamotu, Society and Cook Islands rather than the reefs of the western Pacific. With the exception of the Hawaiian expedition the treatment is chronological. It is based on published sources, except that I have gone over Agassiz's correspondence with John Murray in the University of Edinburgh Library; much of this has been published, however, by G. R. Agassiz (1913) and some interesting excerpts by Deacon (1980).

\section{The Florida Reefs}

Agassiz's initial experience of modern reefs was in the western Atlantic. The first cruise of the Blake, though primarily oceanographic in purpose, took him to Cuba and the Gulf of Mexico from December 1877 to April 1878; the second, from November 1878 to May 1879 to Cuba, Jamaica and the Windward Islands; while the third (June to August 1880) was devoted to the Gulf Stream. He turned first to the work his father had done for the US Coast Survey in Florida in 1851, which had only been partly published (L. Agassiz, 1852).

The elder Agassiz's report is an extremely capable reconnaissance of the reefs, with many insights on reef growth, sedimentation and cementation. It is worth noting that while Dana's work on the Wilkes Expedition had been formally published in 1849 it did not become generally available until 1852 and 1853 , and it was Dana's work which established reefs as an object of scientific enquiry in North America. Agassiz's ecological understanding is reflected in his elegant analogy between the structure of a coral reef and of a forest, perhaps the first time that such a comparison was made (L. Agassiz, 1880:52, 55).

But while professing to accept Darwin's theory of subsidence for the reefs of the Pacific (L. Agassiz, 1880:42-43), Louis anticipated Alexander's later obsession by denying its role in the development of the Florida reefs: 
We are satisfied that as far as coral formations have been observed upon the main-land of Florida, and within the present extent of the coral reefs, no change of relative level has taken place either by subsidence or upheaval of the coral ground, and that all the modifications which the reef has presented at successive periods have been the natural consequence of the growth of reef-building corals, with the subsequent accumulation of their products... (L. Agassiz, 1880:35).

In particular he commented on the implications of this situation for the formation of the atoll-like Marquesas and Dry Tortugas, off the southern tip of Florida. These he found to be

among the most interesting of the whole reef, because, without the phenomena of subsidence to which the atolls or Lagoon Islands of the Pacific are due, they nevertheless closely resemble them-in character. The atolls in the Pacific are formed by the sinking of some island around which corals have established themselves. By the growth of the corals the reef rises as the foundation subsides, and finally reaches the surface as a ring often broken by channels and enclosing a harbor. It is my belief that the Tortugas (though no change has taken place in the sea-bottom on which they rest) were built up by the coral growth around a submarine hill (L. Agassiz, 1880:21-22).

Like his son in later years Louis excluded the question of the origin of that foundation from the problem of the development of the reefs themselves.

Agassiz himself visited the Dry Tortugas and the Florida reefs in March-April 1881, and came to the same conclusion as his father thirty years before:

We must look to many other causes than those of elevation and subsidence for a satisfactory explanation of coral reef formation. All important among these causes are the prevailing winds and currents, the latter charged with sediment which helps to build extensive plateaux from lower depths to levels at which corals can prosper (Agassiz, 1885:121).

In addition to the Florida reefs he also called on the features of the 'atoll' of Alacran Reef, north of Yucatan, Mexico, to illustrate his thesis: 'We need not refer the atoll-shaped form of this reef to subsidence of the Yucatan Bank as a whole, since the action of the prevailing winds and currents would account for all the existing phenomena' (Agassiz, 1885:117).

And he concluded:

It seems to me that the structure of the Marquesas and of Alacran proves conclusively that not one point of difference exists between a barrier reef and an atoll (Agassiz, 1885:118).

Agassiz's point of departure in this study clearly followed his father's essentially ecological approach, and overlooked the fact that Darwin's distinction between fringing reefs, barrier reefs and atolls was primarily topographic and structural rather than ecological. This ecological emphasis was illustrated by the attention he gave to the distribution of the benthos at Dry Tortugas. In his 1885 paper he published a map at a scale of 1:40,000, in color, using nine categories to plot the distribution of corals, octocorals and sediments on the reefs. No one had ever made such a map of reef communities before, and it would be decades before anyone did again. Davis (1982) used the map as a baseline to assess community change when remapping the communities in 1976, and commented on the 'high quality' of the map and Agassiz's 'skill' and 'extraordinary foresight' in making it. Though we do not know how the map was made (or indeed by whom) it was clearly an extremely interesting development in reef studies.

Agassiz's Florida paper differs from the rest of his coral reef work in style as well as in content. 
Like his father's paper - but without his father's clarity - it is an extended argument rather than simply a topographic description. In later work description increasingly outweighed argument and detailed field investigation gave way to more impressionistic observation.

Agassiz revised his views on the Florida reefs considerably in a paper in 1896, after he had visited Bermuda and investigated the raised reefs and other deposits of the Bahamas and Cuba. While previously denying either elevation or subsidence, he now found that the keys from the Dry Tortugas to Key Biscayne were 'the remnants of a long and wide belt of stretches and patches of an elevated coral reef.... The keys are all built upon this elevated coral reef foundation', standing at 2-6ft above high water level. But though he admitted subsidence of about $300 \mathrm{ft}$ in the Bahamas, he found that 'post-Pliocene coral reef' was limited to the upper $50 \mathrm{ft}$ of a $2000 \mathrm{ft}$ deep well at Key West' (Agassiz, 1896:31). Drawing mainly on his Bermuda experience, and undoubtedly influenced by Murray's views, he emphasized the 'mechanical and solvent action of the sea' in excavating what he termed 'sounds' behind the reefs (Agassiz, 1896:29): 'I am now inclined to look upon the Marquesas as merely a broad circular sound, more complete than any other sound formed on the line of the keys, and not as an atoll' (Agassiz, 1896:48).

Agassiz corresponded with Darwin directly during the Florida work, and Darwin was frankly skeptical. 'Is it not difficult to avoid believing that the wonderful elevation in the West Indies must have been accompanied by much subsidence, notwithstanding the state of Florida?' he wrote to Agassiz on New Year's Day, 1881 (F. Darwin and Seward, eds. 1903, 2:147), repeating, the argument he had developed in the Andes about Pacific atolls. And with reference to Agassiz's idea that the reefs had grown on sediments accumulated by waves and currents, he commented on May 5: 'It is a surprising fact that the peninsula of Florida should have remained at the same level for the immense period requisite for the accumulation of so vast a pile of debris' (F. Darwin and Seward, eds. 1903, 2:197). He also insisted that 'I have expressly said that a bank at the proper depth would give rise to an atoll, which could not be distinguished from one formed during subsidence' (F. Darwin and Seward, eds. 1903, 2:198). He made explicit his disbelief in Murray's recent arguments, with which Agassiz agreed:

I can ...hardly believe, in the former presence of as many banks (there having been no subsidence) as there are atolls in the great oceans, within a reasonable depth, on which minute oceanic organisms could have accumulated to the thickness of many hundred feet. ... Lastly, I cannot understand Mr Murray, who admits that small calcareous organisms are dissolved by the carbonic acid in the water at great depths, and that coral reefs, etc., etc., are likewise dissolved near the surface, but that this does not occur at intermediate depths, where he believes that the minute oceanic calcareous organisms accumulate until the bank reaches the reef building depth (F. Darwin and Seward, eds. 1903, 2:198).

Darwin's were points which neither Murray nor Agassiz ever countered.

\section{The Bahamas, Bermuda and Cuba}

Agassiz's studies in the Bahamas and Cuba and at Bermuda were relatively unproblematic. He used them to establish two points. First, the raised reef terraces of Cuba (the highest reaching $400 \mathrm{~m}$ above sea level, though the uppermost not necessarily reefal) clearly indicated substantial reef growth in areas of uplift. Second, the modern reefs of Bermuda and the Bahamas are all thin coatings on other foundations.

The cruise to the Bahamas and Cuba covered 4500 miles during January-April 1893. He found the Bahamas reefs to be thin veneers over an underlying foundation of calcareous aeolianite. The small 'atoll' of Hogsty Reef to the south he believed to have a similar structure, with its lagoon excavated mechanically by waves and currents like a gigantic pothole (Agassiz, 1894a:103-108). At Bermuda too he came down against the necessity of subsidence in explaining the atoll-like form. The reefs were simply thin veneers over disintegrating ledges of aeolianite, which as they eroded left behind foundations for the reefs; indeed the calcareous sand at Bermuda was largely derived from the erosion of the older aeolianite rather than of the modern reefs (Agassiz, 1895b:209, 213, 222). These were themes he was to develop in subsequent 
work. The main innovation in the Bermuda work was in the description of serpulid reefs (Agassiz, 1895b:253-269).

That Agassiz was by this time thinking more broadly about the origin of reefs is shown by his discussion of 'Some recent views on the history of the formation of coral reefs' in the Bahamas and Cuba report (Agassiz, 1894a:170-187). After describing various theories of atoll formation put forward in opposition to Darwin's, Agassiz comments:

The want of unanimity among the opponents of the Darwinian theory of the formation of coral reefs has, it seems to me, nothing to do with the question whether Darwin is right or not. It merely shows that there are many points of difference which are more or less apparent in the various districts examined, by recent writers on coral reefs, and that perhaps the problem of their formation is not quite so simple as the upholders of the subsidence theory would have us believe.... Subsequent investigations in the Pacific and elsewhere have shown most clearly that the reef problem is a most complicated one, and that we have not heard the last word on the subject. As far as the formation of many of the Pacific atolls is concerned, either they have been formed by subsidence, and owe their origin to causes different from those which in the West Indian and other districts have formed atolls upon comparatively shallow bases, or they have been formed by the same causes to which the latter owe their shape independently of subsidence, or we may further assume that atolls can be formed in regions of subsidence independently of the subsidence, as well as in regions where no subsidence has been observed (Agassiz, 1894a:172-173).

Agassiz is at pains to emphasize from a wide variety of studies the thinness of actual reef sequences in elevated limestones, arguing that the limestone itself cannot be taken as an indication of prior subsidence (Agassiz, 1894a:178-183). And he notes the improbability of being 'prepared to accept and imagine a synchronism between the growth of corals and subsidence in a great number of the districts in which they flourish, of which we have no proof' (Agassiz, 1894A:187). Little by little the areas where Darwin's theory might apply have been reduced:

It is not applicable to the West Indian and Caribbean Sea reefs. It does not hold true for the Bahamas or Bermudas, any more than for Galapagos. It has not been accepted by Semper, by Rein, by Murray, by Bourne, by Guppy, nor by others who have in recent years examined many of the localities which are considered by Dana and Darwin as typical of the subsidence theory (Agassiz, 1894a:183).

His conclusions firm, but based mainly on the Western Atlantic reefs, it was time to turn to a wider field. Agassiz (1894a:184-187) concluded his discussion with detailed remarks about the Maldives Archipelago in the central Indian Ocean, seen in the light of his Bahamas experience. The Maldives expedition was to be his last, but henceforth his efforts were to be devoted to non-Atlantic reef seas.

\section{The Hawaiian Reefs}

Agassiz had anticipated his move into the Pacific by a land-based sojourn in the Hawaiian Islands during the winter of 1885, during which he visited Oahu, Maui and Hawaii. His report is a discursive discussion of older theories of coral reef formation (Agassiz, 1899:121-144), followed by his views on the coral reef controversies which erupted in Britain in the years immediately following Darwin's death in 1882, based on Agassiz's Atlantic experience, his observations in Hawaii, and his wider reading on other reefs yet to be visited. He was impressed by the widespread evidence for recent elevation of 6-8 meters given by raised reefs, beachrock and aeolianite; by the influence of river discharge on the windward sides of islands in controlling reef distribution, and by the thinness of successive reefs, interbedded with lavas, 
revealed by the records of artesian wells, some drilled to over 200 meters, on Oahu, Hawaii. Agassiz (1899:154) interpreted the coral sequences as resulting from the seaward extension of the shoreline, with reefs building over talus, rather than developing through subsidence.

He explored the reefs of Kaneohe Bay on the north side of Oahu by canoe, and saw the area as representative of a wider model of reef evolution:

The whole bay before corals began to flourish upon it must have contained a number of small volcanic islands and a large number of sunken volcanic rocks and ledges which have become capped with coral or surrounded by diminutive fringing reefs. What is now going on in the Bay of Kaneohe on a diminutive scale we may apply to groups of volcanic islands in the Pacific. If we add to this the powerful agency of accumulations of limestone on the deeper summits or banks until these surfaces are built up to a height at which corals can begin to grow we have all the various elements needed for the formation of fringing reefs, barrier reefs or atolls within a comparatively limited area as is the case in those archipelagoes of the Pacific where these various kinds of reefs have been observed to occur together. The base upon which the barrier reef of Kaneohe has been built up has probably been formed by the washing down and disintegration of a lava crest of considerable height (Agassiz, 1899:161).

In this interpretation he was clearly impressed with the work of Semper $(1869,1873)$ in the Philippines and Palau and of Guppy (1886) in the Solomon Islands.

\section{The Great Barrier Reef}

Agassiz's knowledge of the Great Barrier Reef was mainly derived from the observations of J.B. Jukes (1847) on the voyage of H.M.S. Fly. Jukes's straightforwardly Darwinian interpretation of the development of the Reef (Stoddart, 1988a) was not at all to Agassiz's liking. As in his previous work he seized on Jukes's evidence for recent elevation of the Reef (though Jukes's interpretation of what he considered to be raised reef has not been sustained: Stoddart et al., 1978:151), claiming that 'observation plainly shows us [before he went there] that there has only been a slight elevation or a stationary condition of the coast line' (Agassiz, 1889:130). He had a more interesting point—which Darwin had made the core of his theory - that subsidence could only be a valid explanation of reef form 'if the rate of growth of corals were absolutely identical with that of the subsidence of the bottom of the sea' (Agassiz, 1889:130). And the rate of subsidence must be uniform:

Is it credible that, along the whole length of the northeast coast of Australia, the subsidence should, for a length of over one thousand miles, be so nearly identical in amount as to have ended in forming parallel to it the Great Barrier Reef? The same question is one which must be answered not only for Australia, but for all the atolls and barrier reefs in the Pacific and other regions where such reefs exist (Agassiz, 1889:130).

The expedition to the Great Barrier Reef was not a success: like so many others before him since the time of Cook, Agassiz was foiled by the strength of the trade winds. He had with him A. G. Mayer and had hoped to have Murray too, but little work could be done. This did not prevent Agassiz's free indulgence in speculative interpretation. After steaming between Hope and Lizard Islands, and with the aid of charts he concluded:

The conclusion seems inevitable that all the flats and reefs lying between 'the outer line of reefs and the mainland are but the remnants of former islands extending to the eastern edge of the continental plateau; islands which once formed a part of the eastern coast of Queensland, and have by erosion and by denudation gradually been separated from the mainland and reduced to the flats forming the outer reef flats of the Great Barrier Reef.... 
After the formation of the islands and islets and after their separation from the mainland, corals began to grow upon the eroded surfaces and flanks of the flats and banks, changing them gradually to reef flats and flanking reefs (Agassiz, 1896a:241-242).

As evidence for this erosion he noted that:

The larger islands are generally nearer the continental shore; as we go out towards the edge of the Barrier Reef they fast become smaller, and near the outer edge of the reef we only find an occasional rocky islet to attest the former existence at from twenty to seventy-five miles from the present shore line of the outer and eastern edge of that continent (Agassiz, 1898c:125).

Thus, 'the present condition of the Great Barrier Reef can be satisfactorily explained by the mere action of erosion and denudation' (Agassiz, 1898c:127). Agassiz added to this the evidence of recent elevation, derived from the widespread existence of conglomerate platforms around the islands, and of 'negro heads, huge masses of coral, the remnants of the elevated coral reef which once flourished upon these flats' (Agassiz, 1896a:243; 1898c:114-119), the erosion of which he believed to be a major source of sediment composing the reef islands (Agassiz, 1989c:122).

He admitted both stratigraphic and structural evidence for both subsidence and elevation on the mainland, dating back to the Cretaceous, but since 'both antedated the present epoch, neither could have influenced the formation of the coral reefs of our epoch or have been the cause of the peculiar shape of the atolls and Barrier Reefs of the South Pacific coral belt' (Agassiz, 1896a:243). From his inferences on the development of the Great Barrier Reef he immediately generalizes about 'the disappearance of the Pacific continent or archipelago':

denudation of the remnants of this Pacific island area has been going on apace with that of the Australian coast (Queensland) cutting down the peaks to form huge banks and isolated islets and islands with more or less extensive banks, upon which and on the flanks of which corals have during the present period found their resting place, and have grown to form barrier or fringing reefs and atolls from a comparatively shallow base line, subsidence having played in their formation but an insignificant part (Agassiz, 1898c:128).

\section{The Reefs of Fiji}

Agassiz spent the winter of 1897-1898 in an extensive exploration of the Fiji Archipelago, a region with a wide diversity of modern and uplifted reefs. The area had recently been visited by Gardiner (1898), but his results were not yet available, and indeed, with the notable exception of W.M. Davis (1920), remarkably little attention has been given to these reefs either before or since Agassiz's expedition. Partly because of the inherently interesting and varied nature of the reefs, and partly because of the trenchancy of Agassiz's final report (1899b), this proved perhaps his most successful reef study, though its conclusions were, however, predictable.

I came to Fiji,' he wrote, 'under the impression that we were to visit a characteristic area of subsidence: for according to Dana and Darwin there is no coral reef region in which it is a simpler matter to follow the various steps of the subsidence which has taken place here' (Agassiz, 1898a:115). But within a mile of Suva he found an elevated reef $50 \mathrm{ft}$ thick and $120 \mathrm{ft}$ above sea-level, and also evidence of extensive volcanic and great denudation, both atmospheric and marine. Fiji represents, he wrote to Murray on 2 December 1887, 'the last nail in the coffin of subsidence (Deacon, 1980:385).

Everywhere he saw denudation preparing foundations for reef growth: 
It seems comparatively simple to follow with the chart the changes which must have taken place in separating from Kandavu the islands enclosed within the Great Astrolabe lagoon north of that island.... If we examine Kandavu Island itself, we can easily see how far denudation and erosion, if continued, could cut it up into a number of larger or smaller islands (Agassiz, 1899b:31-32).

Such erosion could act to prepare reef foundations on either volcanic or elevated limestone rocks:

One cannot fail, on seeing the coral reef growing on the denuded rim of Thombia with the enclosed deep lagoon having a depth of twenty-four fathoms, to revert to the old opinion that some of the lagoons of atolls represented the rim of extinct craters... We must remember, however, that the formation of such atolls may also be accounted for as the result of the denudation and submarine erosion of a patch of elevated limestone, cut first into a sound, and then, with the disappearance of the outer rim, into a lagoon surrounded by a shallow reef flat; or the same result may be accomplished from the wearing away of islets of volcanic origin enclosed within the outer reef (Agassiz, 1899b:35; also 105-109).

In a now familiar argument Agassiz considered that support for the fact that reefs are growing on eroded volcanics, as at Tavuki, Kandavu, 'is clearly seen, from the nature of the negro-heads cropping out in the bay' (Agassiz, 1899b:28). The uplifted and eroded volcanic island of Totoya provided an additional case study (Agassiz, 1899b:37-40).

Agassiz here closely followed Murray, who had also visited Kandavu during the Challenger Expedition. 'It was here that, not being able to apply Mr Darwin's theory in explanation of the phenomena of the Kandavu reefs, I commenced to doubt it altogether. ... The more observations accumulate, the more does it seem to me probable that there never was a barrier reef or atoll formed after the manner required by $\mathrm{Mr}$ Darwin's theory' (Murray, 1899:222). Davis (1928:316) later found it 'utterly impossible' to accept Agassiz's conclusion about submarine erosion, and noted that 'so long as the reef-encircled islands are neglected and only the island encircling reefs are examined, almost any theory of reef origin may be accepted. It is the embayed shoreline of Kandavu and not the mere existence of reefs around it thatdemands subsidence.'

It followed from Agassiz's speculative though emphatic interpretations that modern reefs owed their form to pre-existing topographies:

From this evidence I am inclined to think that the corals of to-day have actually played no part in the shaping of the circular or irregular atolls scattered among the Fiji islands; furthermore that they have had nothing to do in our time with the building up of the barrier reefs surrounding either wholly or in part some of the islands: I also believe that their modifying influence has been entirely limited in the present epoch to the formation of fringing reefs, and that the recent corals living upon the reefs either of the atolls or of the barriers form only a crust of very moderate thickness upon the underlying base. This base may be either a flat of an eroded elevated reef or of a similar substructure of volcanic rocks, the nature of that base depending absolutely upon its character when elevated in a former period to a greater height than it now occupies (Agassiz, 1898a:117).

Agassiz paid particular attention to the elevated limestones in the Lau Archipelago and elsewhere, some of which reached more than $300 \mathrm{~m}$ in elevation. He did not know their age, but because of their resemblance to the raised limestones of Cuba he concluded that they were Tertiary (Agassiz, 1899b:77). He drew a clear distinction between thick ancient limestones and relatively thin modern reef deposits. As elsewhere he believed that the older limestones could have accumulated simply by accretion without the necessity of subsidence, and that the distribution and form of the modern limestones of reefal origin depended on the features of the older beds and that hence in their turn the modern limestones did not 
require subsidence to explain them.

There was one curious episode in the Fiji expedition. Years before Darwin had written to Agassiz with the famous suggestion: 'Would that some doubly rich millionaire would take it into his head to have borings made in some of the Pacific and Indian atolls and bring back cores for slicing from 500-600 ft' (5 May 1881: F. Darwin and Seward, 1903, 2:198). Agassiz took up the proposal in Fiji, and organized a boring at Wailangilala atoll. This took place on the lagoon shore of the main island, at a height of $1.5 \mathrm{~m}$ above the sea. The idea of such a boring was a major scientific issue at the time. In August 1896 the first attempt to core at Funafuti Atoll in the Ellice Islands (Tuvalu), under W. J. Sollas, had been abandoned at only 32 meters. Early in 1897 Agassiz himself had proposed that the attempt be renewed in a joint AngloAmerican expedition, but the idea was not welcomed in England (McLeod, 1988: 170, 186). A second boring expedition under T. W. Edgeworth David was organized from Sydney and commenced work on Funafuti in June 1897; ironically it called at Wailangilala, where Agassiz was to drill several months later, on the way to Funafuti. By the end of September, a month before Agassiz arrived in Suva, boring had been concluded at 213 meters. The following year a third expedition carried the boring to 340 meters, where it was terminated (Royal Society, 1904).

While still in Suva Agassiz had reports that the second Funafuti expedition had found 'true coral reefs' to a depth of $196 \mathrm{~m}$ :

This information seemed so positive that had it been received before the shipping of my outfit to Fiji via Australia, I should have remained at home, convinced that at any rate, whatever had been my experience in the West Indies, Australia, and the Sandwich Island reefs, yet that in a region of typical atolls in the Pacific the conditions of subsidence suggested by Darwin and Dana might exist.... But my outfit having left, I was not prepared to accept the preliminary conclusions of Professor David as recorded by the papers, and I started on my expedition ready to confirm by my own borings the truth of the great thickness of modern coral reefs in atolls of the Pacific, or to give some other explanation of this apparently overwhelming proof of the correctness of Darwin's theory (Agassiz, 1899b:47).

Agassiz therefore established his drilling rig on Wailangilala and work commenced. Inexplicably he did not remain to supervise the project but cruised in eastern Fiji before returning to Suva. There he found that the boring had gone through coral sand deposits to 15 meters before entering yellow limestone. This Agassiz equated with the widespread elevated limestones common throughout Fiji: '... it seemed a waste of both time and money to bore and obtain a core from an indefinite datum plane, when the same evidence could be obtained by the examination of any one of the bluffs of elevated coralliferous limestones with which we had become familiar' (Agassiz, 1899b:48). He sent a signal to Wailangilala and had the boring terminated when it had reached only 26 meters.

It seems in retrospect a dispiriting episode indicative of an extraordinary lack of resolve on Agassiz's part. Yet the failure did not stop him from drawing predictable conclusions. 'The boring shows that the island is the fragment of an ancient island of larger size, which once covered the whole area of the lagoon' (Agassiz, 1899b:48). The limestone is also the substrate of the northern reef flat. And inevitably: 'Many of the reef rocks (negro-heads), which Gardiner considers as having been thrown up by hurricanes, are the remnants of the elevated reef rock outliers left from the denudation of the flats on which they occur, and which once rose to a greater height but have gradually been eroded and planed down to their present elevation' (Agassiz, 1899b:48). Yet in spite of this confidence Agassiz did not have the capability of studying the elevated limestones. He later sent E. C Andrews and B. Sawyer from the University of Sydney to look at them in greater detail (Andrews, 1900; Sawyer and Andrews, 1901) and E.W. Skeats (1903) studied their chemistry. Neither Andrews nor Skeats were attuned to Agassiz's interpretations. Indeed Andrews $(1901,1903)$ rebutted Agassiz's views on the structure of the Great Barrier Reef and in 1914 worked with the arch-Darwinian William Morris Davis in the New Hebrides (Vanuatu), while Skeats (1918) worked on the Funafuti core. 


\section{The Tuamotu Archipelago}

Agassiz's expedition through the tropical Pacific between August 1899 and March 1900 was his longest and most extensive. By the time it began, however, his views were fixed and both his observations and his interpretations were determined by them. Comments on this expedition are confined to the work done at the beginning, in the Tuamotu Archipelago and the Society and Cook Islands.

The Tuamotu comprise the world's largest chain of atolls, uncompromisingly used by Dana following the U.S. Exploring Expedition in support of Darwin's theory of subsidence. Agassiz was not disconcerted. He wrote to his stepmother from Makemo Atoll on 16 October 1899: 'I am gradually knocking out a lot of superstitions about atolls, and it is really absurd that Darwin and Dana should have written such a lot of nonsense, all evolved from their own brains or reading what others have said and done' (G. R. Agassiz 1913, 362). 'I am tickled to death,' he had written three weeks earlier, '... to find myself on familiar ground. I could imagine myself at one of the elevated Fiji atolls... I think I have the key of the Paumotu coral reef problem, and it's only an expansion of what I have seen in Fiji; only this group is comparatively plain sailing and clear work, for Dana did not examine his islands very closely; as, for instance, the greatest detail he gives of an island of the Paumotu group is from what he saw sailing by! As for Darwin, he only sailed through and never stopped at all, so that I am quite sure that unless something new and unforeseen turns up, I can chuck this group of atolls at the heads of the Darwin-Dana party and ask them for the next!' (G. R. Agassiz, 1913:358).

Agassiz's systematic misrepresentation of the structure and history of these atolls began at the first he visited, Rangiroa, one of the largest in the group. Entering the lagoon on the northern side at Tiputa, he found it 'very evident' that 'the ledge underlying the north shore is the remnant of the bed, an old Tertiary coralliferous limestone which at one time covered the greater part of the area of the lagoon, portions of which may have seen elevated to a considerable height. This limestone was gradually denuded and eroded to the level of the sea.... The underlying ledge is not the remnant of a modern reef; its character is identical with that of the elevated limestones of Fiji, which are of Tertiary age, and the rock is in every respect the same as that I observed on many of the elevated islands of Fiji' (Agassiz, 1900a:39). On the small islands near Tiputa this 'tertiary coralliferous limestone' is 'covered over in part with recent stratified beach rock or coral breccia and conglomerate' (Agassiz, 1903a:33). On the windward side of Rangiroa, at Funuarua, he found higher limestones:

This wall was fully 12 feet high, and is the remnant of the ancient coralliferous limestone ridge which flanked the southern side of Rangiroa. This old ledge is deeply pitted and honeycombed and eroded into all kinds of fantastic spires and pinnacles and wall (Agassiz, 1903a:46).

This raised limestone, now known under the Polynesian name feo he also noted at Tikehau and Niau Atolls, and correlated it with thelimestones of the much higher island of Makatea, as well as with the lower ledge outcropping on island shores throughout the Tuamotu atolls. Elsewhere 'it could be traced only as forming the shore platform, from 50 to 150 feet wide, which forms the outer face of the Paumotus':

Everywhere the space between the outcropping of the old ledge, as I will call the Tertiary coralliferous limestone, was filled with beach rock, or a puddingstone, or with a breccia or conglomerate of coralliferous material consisting in part of fragments of the old ledge, and of fragments of recent corals and shells cemented together. The appearance of the old ledge and of the modern reef rock is so strikingly different that it is very simple to distinguish the two (Agassiz, 1903a:112).

At Rangiroa also Agassiz (1903a:35) found that boulders on the reef flat 'indicate the former position of the old land formed of tertiary coralliferous limestone'. After working out this sequence of events at Rangiroa, Tikehau and Mataiva Atolls in the northwest, Agassiz later visited seventeen more atolls in the central and eastern Tuamotu, spending most time at Fakarava and Makemo: 'All the islands 
we have examined are, without exception formed of Tertiary coralliferous limestone which has been elevated to a greater or less extent above the level of the sea, and then planed down by atmospheric agencies and submarine erosion' (Agassiz, 1903a:112). erosional:

Several further general points followed from this interpretation. First, the lagoons of the atolls are

The low atolls have been cut down from the denudation and submarine erosion of higher islands, forming sounds or sinks [lagoons] surrounded at first by high rims subsequently cut into islands or islets with passes leading into the sounds, until the land rims were reduced to the level they now occupy (Agassiz, 1903a:xx).

Second, there is therefore 'a great development of buttresses of tertiary coralliferous limestone; they run across the beaches of the sea face and of the reef platforms, and are the last remnants of the former elevated land once covering a large area of the atolls' (Agassiz, 1903a:xvi). Third, the sand of the island beaches has been derived from the erosion of the former elevated land, to the extent that 'When the coral sand beaches are high, the boulders on the platform [reef flat) are usually absent, having been ground up into fragments to form the sand beaches or the coral shingle beaches' (Agassiz, 1903a:34).

Agassiz's overall conclusion about the origin of the Tuamotu atolls was thus inevitable:

We have seen nothing in the more extended, examination of the group tending to show that there has anywhere been subsidence. On the contrary, the condition of the islands of the Paumotus cannot, it seems to me, be explained on any other theory except that they have been formed in an area of elevation (Agassiz, 1903a:111).

it is not unnatural to look upon the area of the Paumotus, as I am inclined to do, as one of elevation ... so that I am at any rate justified in denying that the Paumotus as such are situated in an area of subsidence, and that subsidence has been the great factor, as is maintained by Darwin and Dana, in the formation of the characteristic atolls of the group (Agassiz, 1900d:43).

Unfortunately Agassiz's interpretation was wrong in almost every particular. While he could not be expected to know that deep drilling at Mururoa and Fangataufa Atolls would show up to 420 meters of coral limestone above volcanic rocks 6.4-8 million years old (Chauveau et al., 1967; Bardintzeff et al., 1985), it is extraordinary that he never questioned why the individual atolls should rise from such deep surrounding waters. He himself was responsible for the first deep soundings through the Tuamotu, recording for example a depth of $2.6 \mathrm{~km}$ between Rangiroa and Tikehau Atolls. But in the Tuamotu as elsewhere he makes no connection between submarine topography and the origin of the surface forms of reefs (Agassiz, 1900d:34).

His equation of the conglomerate platform outcropping around the islands and the deeply dissected and higher feo is simply, wrong (for the case of Rangiroa see Stoddart, 1969:20-23): the conglomerate platform is everywhere of Holocene age (Montaggioni and Pirazzoli, 1984; Pirazzoli and Montaggioni, 1988); it contains no 'Tertiary' fossils; and it bears no resemblance at all either to the feo or to the elevated limestones of Fiji. Feo is of uncertain age, certainly at least Last Interglacial and probably older, and is confined to Mataiva, Tikehau, Rangiroa, Kaukura, Niau and Anaa Atolls in the northwest. It is possibly Miocene, by analogy with the high limestones of Makatea, but this has not been demonstrated. The reef flat limestones are likewise Holocene and not eroded 'Tertiary' limestones as Agassiz supposed. In only one locality has a presumed 'Mio-Pliocene (?)' outcrop of hard, honeycombed, beige colored carbonate rocks' been described, on the north coast of Mataiva, where it appears to form the subsurface foundation of the Holocene reefs (Delesalle, 1985:280,303); this exposure was not however seen by Agassiz.

There is no evidence that either the conglomerate platform or the feo ever covered the area of the lagoons, as Agassiz asserted in the Gilberts as well as in the Tuamotu (Agassiz, 1903a:xvii). Newell (1956:326) dismissed the idea as 'fantastic'. It follows that the lagoons did not form by erosion of the 
Tertiary limestone as Agassiz suggested. Newell (1956:326) also points out that Agassiz 'frequently mistook large reef blocks thrown up by storms and welded to the reef flat as erosion remnants of once higher platforms.' Nor do the sediments of the present beaches derive from the erosion of the elevated Tertiary reef, as Agassiz believed.

\section{The Society Islands and the Cook Islands}

Agassiz was convinced from his Fiji expedition that modern barrier reefs around volcanic islands are thin veneers on marine erosion platforms cut into basalt. In the Society Islands he argued that 'Erosion and denudation have been great factors in shaping the volcanic slopes of the islands of the group, and the wide platform on which the encircling reefs have obtained a foothold has been cut by submarine erosion' (Agassiz, 1903a:xv-xvi). Thus in the case of Tahiti 'the northeast, trades have eroded a wide platform on the east side' where 'here and there an outlier of the volcanic rock can still be traced, giving us a clue to the nature of the underlying platform, and plainly showing that it is only the extension of the spurs of the mainland which have been eroded and washed out to sea'; likewise 'the wide platform carrying the fringing and barrier reefs of the west side of Tahiti has been formed by submarine erosion' (Agassiz, 1903a:149150, 146). He reported that reef islands west of Papeete were volcanic, being remnants of the volcanic flat platform (Agassiz, 1903a:146). Davis (1928:266; also 1918) examined them and found them to be calcareous, giving 'no indication whatever as to the form or depth of the volcanic base which they rest upon'. Crossland $(1928: 577,584)$ stated that 'No outlying volcanic rocks project through the coral at any point. The islets on the reef are all of purely coral formation', adding 'I can make nothing of the account given by Agassiz [of the reefs themselves]. ... He did not see the trenches [groove-and-spur], the most remarkable feature of the reefs. On the idea of marine erosion of platforms in the volcanic rocks as foundations for the reefs in Fiji as well as in Tahiti, Davis (1928:77) comments that 'Had any observer of less experience than Agassiz set forth this explanation it would hardly seem worth controverting': he sees them as 'preferred but unverified suggestions' which 'do not indicate an understanding of physiographic principles. It is largely for that reason that his conclusions cannot command acceptance' (Davis, 1928:7879).

On the neighboring island of Moorea Agassiz (1903a:157) comments that 'as in Tahiti there are but few islands and islets on the barrier reef flats. In Murea they flank its northwestern point ... and are composed of volcanic rocks, as is the underlying reef flat.' This too is preposterous: the only volcanic rocks on these islands are basalt cobbles brought out by Polynesians to form a cooking hearth on one of the islands that like the reef flats are entirely composed of reef-derived materials.

At Bora Bora Agassiz (1903a:135) imagined 'huge platforms of submarine denudation and erosion'. At Maupiti he reported that 'the southern and western reef flats are covered with huge masses of volcanic rocks, the outliers of former volcanic islets and islands once occupying the outer rim of Maupiti' and that 'on the east face of the barrier reef flat ... numerous outliers of volcanic rocks are scattered, indicating the position and structure of the foundation upon which corals have grown' (Agassiz, 1903a:138, 165). 'It would be truly strange', remarked Davis (1928:306), 'if observer of Agassiz' experience should have mistaken limestone blocks, swept by storm waves from the outer reef face upon the reef flat and there gaining a blackened surface from algous growths, for volcanic rocks, as many less experienced observers have done'-yet this exactly what Agassiz did.

Agassiz also made the first field observations on the geomorphology of the reefs of Aitutaki in the southern Cooks, but again completely misinterpreted them. Erroneously identifying storm blocks on the reef edge as 'volcanic negroheads', he argued that:

This group is an excellent example of a volcanic rock flat upon which corals are growing. The formation of the underlying base can be traced, as volcanic outliers outcrop on many places on the barrier reef. Aitutaki shows, perhaps as plainly as any other volcanic island we have visited, the manner in which the lagoon and barrier reef flats 
have been formed from the denudation and erosion of the volcanic mass which once

occupied the area indicated by the outer edge of the barrier reef (Agassiz, 1903a:170).

Apart from the islets of Rapota and Moturakau, the volcanic outliers he refers to are all blackened storm-deposited reef blocks; the reef flats themselves are all of reef limestone and not eroded basalt; the high cliffs which, as Davis (1928:378) argued, must have resulted from marine erosion on such a scale are absent; and all the reef islands are formed exclusively of reef-derived sediments (Stoddart, 1975a, 1975b). Recent drilling has failed to demonstrate the reality of Agassiz's imaginary erosion platforms (Gray, 1991:115). It is clear that by the beginning of his expedition to the tropical Pacific Agassiz's observations on the reefs had become as unreliable as his interpretations.

There was, however, one item in his final report of some interest but which appears to have attracted no subsequent attention, perhaps because of pervasive doubts about the quality of the information on which it was based. Doubtless following Plate III of The Structure and Distribution of Coral Reefs (Darwin, 1842), in which Darwin mapped on a worldwide basis the distribution of the different types of coral reefs and of volcanoes, Agassiz (1903a, Plate 234) constructed a geological chart of the islands in the tropical Pacific. This measured $31.5 \times 51.9 \mathrm{~cm}$ and was at a scale of approximately 1:22 million. It covered the Pacific north to Honshu and south to Pitcairn, west to Palau and east to the longitude of San Francisco. The map color-coded the islands as follows:

Yellow: coral reefs, underlying base not known [this category included virtually all atolls except the Tuamotus].

Blue: volcanic islands.

Carmine: elevated limestones [this category included all the Tuamotus; Oeno, Henderson, Ducie, Christmas, Howland, Baker, Canton, Enderbury, Phoenix, Sydney (but not McKean, Gardner, Birnie and Hull), Lisiansky and Laysan (but not the other Leeward Hawaiian reefs), Abemama (but not the other atolls of the Gilbert and Ellice Islands), Uvea, Nauru and Banaba, Fais in the Carolines, Lau, Tonga, Niue, Mitiaro, Atiu, Mauke and Mangaia].

Blue and carmine: volcanic islands surrounded by reefs, partly elevated.

Green: coral reefs, probably underlaid by rocks of nearest land [Great Barrier Reef of Australia; New Caledonia].

Blue and yellow: volcanic islands surrounded by encircling reefs.

It is notable that most of the islands listed as elevated limestones, except for the Lau Islands, the Tuamotus, Tonga and Niue, had not been seen by Agassiz, and the status of some (such as Oeno and Ducie) was very doubtful. Among atolls other than the Tuamotu Agassiz claimed elevation only for Abemama, with 'old elevated coralliferous limestone', and Tabiteuea, with 'tertiary elevated coralliferous limestone', both in the Gilberts [Kiribati] (Agassiz, 1903a:242, 239). The same criticisms apply to these observations as to those in the Tuamotu.

\section{The Maldives Islands}

Agassiz's final report on the atolls of the Maldive Islands, central Indian Ocean, was relatively uncontentious. As in Fiji he had been anticipated by J. Stanley Gardiner, who had worked through the archipelago from Minikoi Atoll in the north to Addu Atoll in the south between June 1899 and April 1900 (Gardiner, 1903b). Agassiz cruised between Ihavandiffulu Atoll in the north and Addu in December 1901 and January 1902. The whole chain of atolls is enclosed by the 2000-meter isobath, with the sea floor falling sharply to ca $4 \mathrm{~km}$ to both east and west. Between Ihavandiffulu and Haddumati [Hadhdhunmathi] the archipelago consists of a double chain of atolls rising from a plateau $450 \mathrm{~km}$ long, up to $125 \mathrm{~km}$ wide, and varying in depth from 300 meters in the south to over $700 \mathrm{~m}$ in the north. Gardiner $(1902,1903 \mathrm{a}$, 1903b:172-183) had inferred largely on the basis of bathymetric evidence that Darwinian subsidence was an untenable explanation for the development of the atolls, and that the foundations of the reefs had been 
prepared by the erosion of a plateau by ocean currents followed by organic sedimentation on it.

Agassiz was impressed with the great variability of the Maldivian atolls. Some, such as Haddumati, Kolumadulu [Kolhumadulu] and Suvadiva [Huvadhu], were reminiscent in the continuity of their rims and the depth of their lagoons of the larger Pacific atolls. But many of the northern atolls had rims themselves composed of small atoll-shaped reefs or faros, which are rarely found elsewhere in the world:

To understand the coral reefs of the Maldives, we must look upon each ring or faro or islet or island on a reef flat as a thing by itself, just as much entitled to be called an atoll as any of the smaller atolls found in the Pacific, - atolls which only incidentally play a secondary part as reef flats of the outer faces of the groups, but which in spite of their position do not hold to the enclosed water the same relation which the reef flats or land rim of an atoll hold to the enclosed lagoon (Agassiz, 1903b:82).

And again:

The faros, or atolls, or lagoon reefs, built up on the summits of the plateaus rising from various depths, are all atolls, though they may differ greatly in size and shape, they all represent variations similar in kind; there is no fundamental difference between them. The lagoons of the largest Maldivian atolls ... are but little deeper than the lagoons of smaller faros ... We cannot distinguish these faros from atolls, whether isolated of forming part of an extensive chain, or occupying a portion of the face of the Maldivian plateau, or scattered within the basins enclosed by these chains. The faros and atolls have the same characteristic features (Agassiz, 1903b:58).

In the case of Tiladummati-Miladummadulu [Thiladhunmathi- Miladhunmadulu], surface reefs, including faros, occupy only a minor proportion of the periphery of the bank, 'a condition which can hardly be called that of an atoll':

Such a state of things seems to indicate that coral reefs and atolls may begin at any point or knoll or ridge or range or summit or flat of a plateau, having the depth at which corals may begin to form, provided its waters have the necessary temperature and the proper exposure to currents or trades. The surface of the Maldivian plateau consists of a host of such knolls, summits, and ridges of greater or less dimension, upon which have risen the complicated system of islands, faros, reef flats, and atolls with which we have become familiar during our exploration of the Maldives (Agassiz, 1903b:81-82).

Thus Agassiz's explanation of this archipelago is simply that 'the composite atolls of the Maldives have arisen upon minor elevations upon the Greater Maldive plateau which have given to the reef-building corals a base at the proper depth from which they have risen to the surface' (Agassiz, 1903b:xx). As elsewhere he excludes the origin of these foundations from the coral reef problem. Davis (1928:527) commented that to the extent that this was any explanation at all, it was 'not supported by any independent and convincing evidence.... Agassiz view is wholly without independent verification', as indeed was Gardiner's.

The atolls of the Maldive Islands were the first reefs studied by Agassiz that lay outside the influence of unidirectional trade winds. Instead they were affected, and both growth and sedimentation patterns in large degree controlled by, the seasonally-reversing monsoons. Depending on aspect and location these led to the enclosure of lagoons by spit-extension from crescentic reefs and islands, and ultimately to the formation of faros. This

... seems to me to point to the uselessness of our present definition of atolls. There is every possible gradation between a curved, crescent-shaped open bank of greater or less size and an absolutely closed ring of land surrounding a lagoon without direct communication with the sea.... reef corals will grow upon any foundation where they 
find the proper depth, and that local conditions will determine their existence as fringing reefs, barrier reefs, or atolls. In fact, in the Maldives, reefs that once formed an atoll may in time, when the atoll or faro is changed into an island, become fringing reefs...

(Agassiz, 1903b:xix-xx).

And he maintained his animus against Darwin to the end. On 18 January 1902, shortly before leaving the Maldives, he wrote to Murray from Miladummadulu:

Such a lot of twaddle has been written about the Maldives. It's all wrong what Darwin has said, and the charts ought to have told him that he was talking nonsense. I am afraid Gardiner also came down with a theory and saw much that he wanted to see [my italics] (G. R. Agassiz, 1913:394).

It was a not inappropriate comment at the end of Agassiz's own active reef investigations. And it may be noted that deep boring on North Male Atoll has recovered over $2 \mathrm{~km}$ of carbonate rocks dating back to the Eocene, overlying volcanic rocks, and that seismic records indicate complex structures in the carbonates. The faros of the atoll rims are now interpreted as karst erosion features dating from glacial low stands of the sea, a process unknown both to Agassiz and Gardiner (Purdy and Bertram, 1991). At least all of the cemented sediments - conglomerates and beachrocks - are recent (Stoddart et al., 1966), and Agassiz was unable to discover again his otherwise apparently ubiquitous 'tertiary coralliferous platform' as a key to atoll morphology.

\section{AGASSIZ'S FINAL VIEWS ON REEFS}

Agassiz now considered his fieldwork over, and in a letter of 18 January 1902 to Murray from Miladummadulu he wrote:

I am ready to have my say on coral reefs and to write a connected account of coral reefs based on what I have seen. It will be a pleasure to me to write such a book and illustrate it properly by charts and photographs. But it will be quite a job with my other work on hand. I hope to live to 100 ! or rather I don't hope, but ought to! finish all (G. R. Agassiz, 1913:394).

The fact that such a work was 'in progress' became generally known (Gardiner, 1906:1056). Its career was later charted by Murray from Agassiz's correspondence and conversations (Murray, 1911). By 1907 Agassiz wrote: 'I have started my coral-reef book, but it is a job, a good deal more than I expected'. Later the same year he reported that 'I have made a fair beginning, and hope to keep the material within reasonable bounds'. In late 1909: 'I have worked hard at my coral-reef book'. Only a few days before his death, he told Murray in London that 'he had really sketched out this book three times, but found it very difficult indeed to deal satisfactorily with the mass of information thathadbeen collected. Itwas his intention, he stated, to write this book during the present year practically for the fourth and last time, leaving out all criticism of the work of others, and stating exactly what he himself observed and his own views.' But he did not leave behind 'any manuscript suitable for publication giving a connected statement of his views.' His son recalled that:

The material he left furnishes an excellent example of his method of carrying his work in his head until the last moment. At his death nothing could be found but a vast collection of extracts from the literature of the subject marked and scored, and a few rough notes, of no use to anyone but himself (G. R. Agassiz, 1913:395-396).

His final general statement, other than those in the reports on the Maldives and the tropical Pacific, 
both of which were published in 1903, was in a lecture to the Royal Society of London, of which he was a Foreign Member. He had traveled to Europe at Christmas 1902, and sent his paper from Paris at the beginning of February. It was read on March 19, 1903: the text occupies but two and a half pages in the Society's Proceedings (Agassiz, 1903c). It is bland as well as brief, and can have conveyed nothing new to anyone familiar with Agassiz's expeditionary reports. He limits himself to one general statement, and indeed mentions only one other reef worker:

Recognizing that Darwin's theory did not explain the conditions observed [in the areas he visited], my reports were limited to descriptions of the different types of coral reefs and of the causes to which they probably owed their formation, and no attempt was made to establish any independent general theory (Agassiz, 1903c:412).

It was scarcely a clarion call to new understanding of the coral reef problem. Murray (1911) recalled that the 'real point' of the address came out in the subsequent discussion: 'that in all his investigations and voyages he had not seen one single atoll or barrier-reef which could be said to be an illustration of the Darwinian theory of coral reefs.' But Agassiz himself was disappointed with the discussion following his paper, because most of the fellows of the Royal Society who were interested in coral reefs were deeply involved with the report on the Funafuti borings (Royal Society, 1904), which had not yet been published and on the implications of which the Society had resolved to be neutral (G. R. Agassiz, 1913:408-409).

Such conclusions as one can reach about Agassiz's coral reef work must therefore be extracted from the individual reports.

\section{STYLE AND AIMS IN AGASSIZ'S CORAL REEF WORK}

Agassiz was born in December 1835, two days before H.M.S. Beagle came within sight of New Zealand after a sector of the voyage during which Darwin wrote out the first full version of his coral reef theory (Darwin, 1962). In 1909, shortly before he died, Agassiz wrote to John Murray to say that his work had led him 'to dissent in toto from the views of Dana and Darwin regarding the mode of formation of barrier reefs and atolls' (Murray, 1911:24). As we have seen, he lost no opportunity on his many expeditions to denigrate Darwin and his views. In reviewing previous reef theories in his Hawaii report, he nevertheless shows but scant familiarity with Darwin's work:

Darwin, it should be remembered, examined only the Great Chagos Bank, and based his speculations on the observations he made on this single group, supplementing the knowledge, however, by a most exhaustive analysis of the observations and descriptions of others...

Darwin, he should have remembered, never visited the Chagos Archipelago at all, but learned of its reefs from the hydrographic surveyor Captain Moresby on his return. In speaking of Cocos-Keeling Atoll, however, Agassiz refers to it in the same paper as 'the very one which Darwin first examined, and which suggested to him his whole theory' (Agassiz, 1889:138). It is, of course, well known that Darwin had his first insight into subsidence and reef origins while still in the Andes and that he comprehensively worked out his theory after seeing the reef-encircled island of Moorea from Tahiti in April 1835 (Stoddart, 1976).

Agassiz's animus against Darwin is apparent in a letter he wrote to Murray on 27 January 1890: '5 days on a reef at utmost and then nothing but examination of charts!! to build up a theory, absurd' (Deacon, 1980:383). Beagle, it might be noted, arrived at Cocos-Keeling on April 1 and left on April 12 1836. Agassiz's objection to Darwin's use of charts is curious. He admits that Darwin made 'a most thorough examination of the hydrographic charts which had any bearing on the subject ... [and] which form so essential a part in the Darwinian theory of coral reefs', but this, 'while interesting, can lead to no sound conclusion' (Agassiz, 1889:121). It was however precisely on such charts that Agassiz himself relied on his 
major expeditions to the Great Barrier Reef, Fiji, the tropical Pacific and the Maldives, not only for descriptive detail but also for bathymetric profiles, and all his reports are copiously illustrated by excerpts from them. Indeed many of his published descriptions of reefs could have been written from the charts in the Harvard Museum without going to sea at all, and without the added errors that his own personal observations supplied.

In the Great Barrier Reef report, he could not resist the observation that:

It is remarkable that Darwin, who is so strongly opposed to all cataclysmic explanations, should in the case, of the coral reefs cling to a theory which is based upon the disappearance of a Pacific continent, and be apparently so unwilling to recognize the agency of more natural and far simpler causes (Agassiz, 1898:130-131).

This is a caricature of Darwin's views, since Darwin was concerned with the subsidence of individual insular volcanoes and not with the disappearance of continents (Stoddart, 1976).

It is hence difficult to agree with Margaret Deacon's assessment that Agassiz 'was not ... emotionally involved, as Murray undoubtedly was, in proving one theory and disproving another': that 'He wanted to look at the facts objectively and then decide' (Deacon, 1971:385). That was not Agassiz's style. Alfred Goldsborough Mayer, the only one of Agassiz's reef associates who seems to have survived unscathed, termed him an 'autocrat' who 'was accustomed to command and to be obeyed' and who was 'quick to anger' (Mayer, 1910:465-466). He got rid of J. W. Fellowes after the Florida investigations, had Thomas Jaggard fired from Harvard following Hawaii, and 'derailed' C. B. Davenport's career because of 'personal dislike' (Winsor, 1991:211). In his Newport laboratory Agassiz 'ensured that the students could not be equals, would not feel part of a research community 'as they were beginning to do elsewhere, and would have trouble establishing their own research agendas' (Maienschein, 1991:1050); indeed he finally excluded them altogether. He preferred the services of scientific employees to the collaboration of colleagues, and thus had no one to criticize his views. For example he commissioned R. T. Hill to work on the geology of Cuba, Jamaica and Puerto Rico following his Caribbean cruise in 1893 (Hill, 1894, 1895, 1899), and E. C. Andrews similarly following the Fiji expedition in 1897-1898 to look further at the elevated limestones (Andrews, 1900). Mayer was undoubtedly the most capable of all the assistants Agassiz took on his expeditions. He established his reputation with his monograph on The Medusae of the World (Mayer, 1910a) in the year of Agassiz's death, and went on to do much innovative reef ecology as well as direct the Tortugas Marine Laboratory of the Carnegie Institution (Davenport, 1924; Colin, 1980). His highly sympathetic memoir of Agassiz nevertheless shows that he was painfully aware of the shortcomings of Agassiz's style of reef science (Mayer, 1910b).

Only with John Murray did Agassiz maintain cordial personal and scientific relations from the time of their first meeting in 1873 until his death. 'Our ideas are about the same', he had written to Murray after the Alacran work, on 20 August 1880, and in spite of some disagreement over the relative importance of solution in forming reef features this theme is maintained in over 200 letters Agassiz wrote to Murray between May 1877 and March 1909 (Edinburgh University Library). A more detailed comparison of Agassiz and Murray would be rewarding: both were self-made wealthy men, both held iconoclastic views directed against leading figures in science, neither held university appointments.

Agassiz's reputation did not, of course, depend on his coral reef studies. In addition to his management of the Museum of Comparative Zoology he was known for his zoological and oceanographic work. He worked particularly on echinoderms, his major contribution being the Revision of the Echini in 1872-1874. On the basis of this, which also earned his father's approbation, Thomson invited him to work on the Challenger echinoids (Agassiz, 1881). The value of this work appears open to question, however. Mortensen 'realized how unpardonably carelessly the latter work especially is done' and his 'respect turned to anger at seeing what damage is done to science by such a bad work being generally taken as a standard work, whose statements nobody ventured to doubt' (Winsor, 1991:238: T. Mortensen to H. L. Clark, 14 November 1908). Indeed, it has been said that Agassiz 'confused sea urchin taxonomy for some time' (Maienschein, 1991:1051). 
Agassiz also claimed on the basis of his deep hauls that there was very little life in the oceans below about 300 fathoms (550 meters), except on the bottom itself. This 'azoic' theory was not confirmed by European investigators, and 'must have seemed inexplicable, if not completely wrongheaded, to Chun and the Prince of Monaco, who had found animals virtually everywhere they sought them' (Mills, 1980:365). According to Mills, Agassiz both had inappropriate collecting equipment, and also 'chose the worst possible sampling areas to search for resolution of the problem'. But there was a deeper difficulty: 'If theory and observation differed, the theory must be wrong, especially if an eminent authority were responsible for it. ... Alexander Agassiz's individuality and practically-oriented abilities would always have placed him in opposition to received opinion' (Mills, 1980:369).

In one area, however, Agassiz made signal contributions. Deep-sea sounding had been revolutionized in the 1870s by the use of steel wire, and Agassiz's engineering talents led him to experiment with a number of sounding machines on his expeditions, beginning with the Blake and early Albatross cruises. On the tropical Pacific expedition he occupied no less than 249 stations (Agassiz, 1903a:379-392), and delineated for the first time the submarine topography of major groups of atolls. His deeper soundings through the Tuamotus ranged from 2400 to 4500 meters and gave the first insight into the morphology of the group. He demonstrated the existence of great depths even between neighboring atolls (e.g. $2700 \mathrm{~m}$ between Rangiroa and Tikehau) (Agassiz, 1903a:33-61, 78-171). He showed that the atolls of the Gilbert and Ellice Islands [Kiribati and Tuvalu] were isolated peaks rising from depths of 2700-3700 m. Thirty soundings in the Marshall Islands showed these too consisted of isolated peaks with intervening depths of $3700-4600 \mathrm{~m}$. The high islands and atolls of the Carolines were separated by depths of 3950-4600 m. His deepest sounding was at $1251^{\prime} \mathrm{N} ; 14546{ }^{\prime} \mathrm{E}$, where he recorded $8.8 \mathrm{~km}$ in the Marianas Trench (where the greatest depth is now known to be $10.9 \mathrm{~km}$ ); this was substantially greater than his greatest Atlantic sounding of $6.2 \mathrm{~km}$ in the Bartlett Trough.

But the astonishing and inexplicable point is that Agassiz quite failed to see the relevance of these data to the coral reef problem or to understand that the submarine topography had any bearing on the questions of reef morphology and origin he was investigating. His reports detail his bathymetric work on the one hand and his reef descriptions on the other, but make no connection between the two. Nevertheless it is clear that his sounding, and also his sea-floor dredging gave Agassiz much satisfaction, perhaps because both yielded essentially unproblematic facts. That is soundings, plotted on a chart, added to the edifice of scientific knowledge: they did not need to be complicated by theory and speculation.

\section{ALEXANDER AGASSIZ: THE ATHEORETIC MAN}

Two facts seem to characterize much of Agassiz's reef work. First, as in the case of the deep-sea soundings, he so narrowed the scope of the evidence he was prepared to admit into the coral reef problem that he was reduced to considering only what he could read on the chart or see from the deck of the ship: anything that could not be directly observed was simply speculation. Second, the facts that could be observed were so diverse and the reports about them were so varied that, generalization was impossible: the best that could be done was to describe every individual reef area as minutely as possible, and leave it at that.

It was a profoundly pessimistic approach to science that he first fully expressed on the Fiji expedition:

On looking over the literature on coral reefs, one cannot fail to be struck with the amount of irrelevant matter which has been passed down from writer to writer. Statements made on hearsay have gradually become facts. The observations of inexperienced persons receive general recognition. Special cases are discussed without reference to their limited or exceptional application. The whole question is often threshed out de novo, so that it is difficult to separate the new from the old. And, finally, information gathered from charts is substituted for observation in dealing with questions which the latter alone can settle.... 
we may go on searching for ever... until the last remaining atoll has been hunted down (Agassiz, 1899b:5).

The diversity of the Fiji reefs in particular and their contrast with others was such that: 'It is becoming more and more apparent that each locality must be considered by itself, and that no sweeping generalization can take in the formation of all coral reefs' (Agassiz, 1899b:41).

It thus became almost inevitable for him to conclude that: 'there is no general theory of the formation of coral reefs, either of barrier reefs or atolls, applicable to all districts.... each district must be examined by itself' (Agassiz, 1899b:144).

Very similar views had been put forward the previous year by Murray, though in a much more positive manner:

... each reef must have peculiarities depending on the nature and form of its foundation, and the meteorological and other conditions of the seas in which the reef is situated; it is only by a careful and detailed study of all these conditions that the peculiarities of any individual reef can be fully explained. At the same time it appears to me that the general and well-known characteristic features and form of coral reefs can be accounted for by reference to certain general considerations, chief among these being the vigorous growth of reef- forming species in positions and at depths where the supply of pelagic oceanic organisms, which form their food, are more abundant and the removal of dead coral and coral debris wherever this is exposed to the action of sea-water (Murray, 1888:414).

Insofar as Agassiz had any general conclusion at all, it was that 'in all the cases I have examined, the reefs formbut a thin crust upon the underlying base, the shape and composition of which is not in any way due to the growth of corals of the existing period' (Agassiz, 1899b:144). By restricting his attention to reefs 'of the existing period' and systematically excluding questions of the development of their foundations from discussion of the coral reef problem, Agassiz ensured that he had nothing of significance to add.

He failed to understand the basic value of theory in science: that by making inferences and logical connections between known facts it is possible to make testable predictions about things not yet observed, and to detect anomalies requiring further investigation. This was the power of Darwin's explanation of reefs, and its absence trivialized Agassiz's entire reef endeavor. It is true that Agassiz's interpretation could be subsumed under what was later termed the Antecedent Platform Theory of reef development: 'This theory holds that any bench or bank ... that is located at a proper depth within the circum-equatorial coral reef zone can be considered a potential reef foundation, and that, if ecological conditions permit, a reef could grow up to the surface without any progressive change in ocean-level' (Ladd and Hoffmeister, 1936:89-90; also Hoffmeister and Ladd, 1944:389). Such a statement is of course tautologously true: it leads in the direction of retrospective explanation of any particular reef but makes no predictive statements open to test. It is not without interest that its formal statement derived from fieldwork in both Fiji and Tonga in the context of both marine erosion and elevation, but without specific reference to Agassiz's observations in either place. And when Hoffmeister and Ladd (1935) discuss the importance of non-reef limestones as foundations for modern reefs, drawing on observations on Bua and in the Lau Archipelago, Agassiz's reports are likewise ignored.

The weakness of Agassiz's coral reef program is thus on a deeper level than simply the erroneous nature of too many of his observations or the speculative nature of his explanations. It is difficult to resist the conclusion that he so restricted his view of the coral reef problem that when the opportunity came to write his final statement about it he found he had nothing to say, other than to repeat the descriptions of his many previous reports. His description of atoll shape in the tropical Pacific paper may be taken as indicative: 
Taking the Paumotus, as a whole, the atolls are elliptical; the few of irregular outline have rounded corners, and a number are circular. In Fiji many of the Lau Islands are most irregular in outline; others, on the contrary, are circular or elliptical. The principal atolls of the Ellice Islands are of very different shapes. In the Gilbert group we have atolls varying from triangular to rectangular and elliptical or angular shape, not a single atoll having the so-called typical outline. In the Marshalls a few atolls are circular, but the majority of the large atolls vary even more in shape than those of the groups we have enumerated. The Carolines likewise vary greatly in outline, both the volcanic islands as well as the low groups. In fact, by far the great majority of the atolls of the tropical Pacific are irregular in outline, and it would be impossible to detect from the charts their resemblance to the typical atoll (Agassiz 1903a, 277).

Agassiz simply leaves the discussion there: the shape must derive from an earlier topography and has thus nothing to do with the coral reef problem as he defined it.

Agassiz's explanations for the forms of modern reefs are very few in number. The reefs are thin and genetically unrelated to the foundations on which they lie. Even where they cap thick limestone sequences, these older limestones are not derived from coral reefs but from other modes of deposition, and the modern reefs are not genetically related to them. Most reef foundations have been formed by marine erosion, either of volcanic islands or of older limestones. Most modern reef topography, including the formation of lagoons, derives from the marine erosion of older elevated reef limestones formed in Tertiary times, and genetically unrelated to modem reefs. Modern reefs, which alone comprise the coral reef problem, may have a multiplicity of forms and origins having nothing to do with modern reef growth. Agassiz himself was trained as a zoologist and a civil engineer, and in spite of his mining experience seems to have had little understanding of geology. In particular he had no sense of chronology, no idea of the rates of operation of processes upon the reefs, and no feeling for the geological importance of corals as producers of reefframework and reef sediment.

There is a final irony in the fact that in spite of his father having been in large degree the originator of the idea of continental glaciation in the Pleistocene, Agassiz never grasped its implications for coral reefs or indeed realized the variability in worldwide sea-level that it implied. It is now realized that while Darwin's theory holds the key to reef structure, especially in the open-ocean basins, the surface form of reefs has been largely controlled by Pleistocene fluctuations in sea-level (Stoddart, 1973).

It was a further irony that it was only eight months after Agassiz's death that R. A. Daly announced his 'glacial-control theory' of coral reef development in the American Journal of Science. By emphasizing the scale and recency of sea-level change Daly claimed to supply 'a missing link in the chain of argument used by Semper, Rein, Murray, Agassiz and Guppy against the wholesale-subsidence hypothesis' (Daly, 1910:298). And further:

Correlating ice-caps and coral reefs, we use the great discovery of Louis Agassiz to support a principal conclusion of Alexander Agassiz. To the father, a zoologist, geology owes the glacial theory; to the son, a zoologist, geology owes a matchless collection of facts, which not only illuminate the theory of coral reefs, but also profoundly affect the problem of crustal deformation in the oceanic areas (Daly, 1910:308).

The best that could be said of Agassiz's reef work on his death was that his results 'depend on a far greater number of original observations, in widely scattered areas, than have been made by all the other authorities on coral reefs put together' (Murray, 1911:30). It was certainly true, as his son claimed, that the range of Agassiz's field investigations had 'not been even approximated by any other man' (G. R. Agassiz, 1913:396). But Mayer's conclusion was more acute, for he realized from his own experience that:

... this very virtue of his exploration is its chief fault, for the study of coral reefs is a complex problem, and it cannot be solved by a superficial inspection such as he was 
forced to make. No one realized this more fully than he did himself, but he believed that the subject should be approached by a superficial survey of all of the reefs of the world, and thus he might hope to discover places where the problem might afterwards be studied with decisive results.... Unfortunately the very multitude of Alexander Agassiz's observations and the somewhat confused style of his writing renders him difficult to follow. Had he enjoyed greater experience as a lecturer he might have become a clearer writer (Mayer, 1910:461).

One must agree with Mayer that the coral reef problem demanded a more intensive and prolonged study than Agassiz was able - or indeed chose - to make.

\section{ACKOWLEDGEMENTS}

An earlier version of this paper was given at the XVII Pacific Science Congress, Honolulu, Hawaii, in 1991. I thank the University of California at Berkeley for support to attend that meeting. Dr T. P. Scoffin kindly provided copies of material from the Murray Papers, University of Edinburgh Library. My work on the Agassiz Papers in the Ernst Mayr Library at the Museum of Comparative Zoology, Harvard University, was supported in part by the University of California at Berkley.

\section{REFERENCES}

Agassiz, A. 1872-1874.Revision of the Echini. Mem. Mus. Comp. Zool. Harvard Coll. 7, 1-762, 94 pl. Agassiz, A. 1881. Report on the Echinoidea dredged by H.M.S. 'Challenger' during the years 1873-1876. Challenger Exped. Zool. 3(1), 1-321, 45 pl.

Agassiz A. 1885. Explorations of the surface fauna of the Gulf Strait, under the auspices of the United States Coast Survey. - II. The Tortugas and Florida reefs. Mem. Am. Acad. Arts Sci. 11, 107-134, $12 \mathrm{pl}$.

Agassiz, A.1888. Three cruises of the United States Coast and Geodetic Steamer Blake in the Gulf of Mexico, in the Caribbean Sea, and along the Atlantic coast of the United States, from 1877 to 1880. London: Sampson Low, Marston, Searle and Rivington. 2 vols. [also Bull. Mus. Comp. Zool. Harvard Coll. 14 and 15]. See Chapter 3, 52-92: The Florida Reefs.

Agassiz, A.1889. The coral reefs of the Hawaiian Islands. Bull. Mus. Comp. Zool. Harvard Coll. 17, $121-170,13 \mathrm{pl}$.

Agassiz, A.1890. On the rate of growth of corals. Bull. Mus. Comp. Zool. Harvard Coll. 20, 1-6, 4 pl. Agassiz, A.1892. General sketch of the expedition of the "Albatross" from February to May, 1891. Bull. Mus. Comp. Zool. Harvard Coll. 23, 1-89, 22 pl.

Agassiz, A.1894a. A reconnaissance of the Bahamas and of the elevated reefs of Cuba in the steam yacht Wild DuckJanuary to April, 1893. Bull. Mus. Comp. Zool. Harvard Coll. 26, 1-281, $47 \mathrm{pl}$.

Agassiz, A.1894b. Notes from the Bermudas. Am, J. Sci. (3) 47, 411-416.

Agassiz, A.1895a. Note on the Florida reef. Am. J. Sci. (3) 49, 154-155.

Agassiz, A. 1895b. A visit to the Bermudas in March, 1894. Bull. Mus. Comp. Zool. Harvard Coll. 26(2), 209-281, $30 \mathrm{pl}$.

Agassiz, A. 1896a. A visit to the Great Barrier Reef of Australia. Am. J. Sci. (4) 2, 240-244.

Agassiz, A. 1896b. The elevated reef of Florida. With notes on the geology of southern Florida by

Leon S. Griswold. Bull. Mus. Comp. Zool. Harvard Coll. 28(2), 27-62, 17 pl.

Agassiz, A. 1898a. The islands and coral reefs of the Fiji Group. Am. J. Sci. (4) 5, 113-123

Agassiz, A. 1898 b. The tertiary elevated reefs of Fiji. Am. J. Sci. (4) 6, 155-167.

Agassiz, A. 1898c. A visit to the Great Barrier Reef of Australia in the steamer Croydon, during April 
and May, 1896. Bull. Mus. Comp. Zool.Harvard Coll.28(4), 95-148, 42 pl.

Agassiz, A.1899a. Cruise of the Albatross. Science n.s. 10, 834-841.

Agassiz, A. 1899b. The islands and coral reefs of Fiji. Bull. Mus. Comp. Zool. Harvard Coll. 33, 1-167, $120 \mathrm{pl}$.

Agassiz, A. 1900a. Explorations of the Albatross in the Pacific Ocean. Am. J. Sci. (4) 9, 33-43, 109-116, 193-198, 369-374.

Agassiz, A. 1900b. Explorations of the Albatross in the Pacific. Nature, 62, 307-311.

Agassiz, A. 1902. An expedition to the Maldives. Am. J. Sci. (4) 13, 297-308.

Agassiz, A. 1903a. The coral reefs of the tropical Pacific. Mem. Mus. Comp. Zool. Harvard Coll. 28, 1$410,238 \mathrm{pl}$.

Agassiz, A. 1903b. The coral reefs of the Maldives. Mem. Mus. Comp. Zool. Harvard Coll. 29, 1-168, $82 \mathrm{pl}$.

Agassiz, A. 1903c. On the formation of barrier reefs and of the different types of atolls. Proc. R. Soc. Land. 71, 412-414.

Agassiz, A. and De Pourtales, L. F. 1875.Recent corals from Tilibiche, Peru. Bull. Mus. Comp. Zool. Harvard Coll. 3, 287-290.

Agassiz, G. R., ed. 1913. Letters and recollections of Alexander Agassiz, with a sketch of his life and work. London: Constable. $454 \mathrm{pp}$

Agassiz, L. 1852. Extracts from the report on the examination of the Florida reefs, keys and coast. U.S. Coast Survey for 1851, 145-160.

Agassiz, L. 1880. Report on the Florida reefs accompanied by illustrations of Florida corals. Mem. Mus. Comp. Zool. Harvard Coll. 7(1), 1-61, 23 pl.

Andrews, E. C. 1900. The general geology of the Fiji Islands. Bull. Mus. Comp. Zool. Harvard Coll. 38, $1-50$.

Andrews, E. C. 1916. Relations of coral reefs to crustal movements in the Fiji Islands. Am. J. Sci. (4) 41, 135-141.

Andrews, E. C. 1922. Contributions to the hypothesis of coral reef formations. Proc. R. Soc. N.S.W. 56, $10-38$.

Bardintzeff, J.-M., Brousse, R. and Gachon, A. 1985. Conditions of building of coral reefs on a volcano: Mururuoa in Tuamotu and Rurutu in Australes (French Polynesia). Proc. 6th Int. Coral Reef Congr. 6, 401-405.

Chauveau, J. C., Deneufbourg, G. and Garcia, J. A. 1967. Observations sur l'infrastructure de l'atoll de Mururoa (Archipel des Tuamotu, Pacifique sud). C.R. hebd. Seanc. Acad. Sci. D 265, 1113-1116.

Colin, P. 1980. A brief history of the Tortugas Marine Laboratory and the Department of Marine Biology, Carnegie Institution of Washington. M. Sears and D. Merriman, eds.: Oceanography: the past (New York: Springer), 138-147.

Crossland, C. 1928. Coral reefs of Tahiti, Moorea and Rarotonga. J. Linn. Soc. Lond. Zool. 36, 577-620.

Daly, R. A. 1910. Pleistocene glaciation and the coral reef problem. Am. J. Sci. (4) 30, 297-308.

Darwin, C. R. 1842. The structure and distribution of coral reefs. London: Smith, Elder. 214 pp.

Darwin, C. R. 1962. Coral islands, with introduction, map and remarks by D. R. Stoddart. Atoll Res. Bull. 88,1-20.

Darwin, F. and Seward, A. C., eds. 1903. More letters of Charles Darwin: a record of his work in a series of hitherto unpublished letters. London: John Murray. 2 vols.

Davenport, C. B. 1924. Alfred Goldsborough Mayor. Biog. Mem. Memb. Nat. Acad. Sci. 21 (8), 1-10.

Davis, W. M. 1918. Les falaises et les recifs coralliens de Tahiti. Ann. de Geog. 27, 241-284.

Davis, W. M. 1920. The islands and coral reefs of-Fiji. Geogrl. J. 55, 34-45, 200-220, 377-388.

Davis, W. M. 1928. The coral reef problem. New York: American Geographical Society (Special Publication No 9). 596 pp.

Deacon, M. 1971. Scientists and the sea 1650-1900: a study of marine science. London: Academic Press. 
$445 \mathrm{pp}$.

Deacon, M. 1980. Some aspects of Anglo American co-operation in marine science, 1660-1914. M.

Sears and D. Merriman, eds.: Oceanography: the past (New York: Springer), 101-113.

Dupree, A. Hunter. 1970. Alexander Agassiz. Dict. Sci. Biog. 1,71-72.

Gardiner, J. S. 1898. The coral reefs of Funafuti, Rotuma and Fiji. Proc. Camb. Phil. Soc. 9, 417-503.

Gardiner, J. S. 1902. The formation of the Maldives. Geogrl. J. 19, 277-296.

Gardiner, J. S. 1903a. The origin of coral reefs as shown by the Maldives. Am. J. Sci. (4) 16, 203-213.

Gardiner, J. S. 1903b. The Maldive and Laccadive groups, with notes on other coral formations in the Indian Ocean. J. S. Gardiner: The Fauna and Geography of the Maldive and Laccadive Archipelagoes. Cambridge: Cambridge University Press, 1, 2-50, 146-183, 313-346, 376423.

Gardiner, J. S. 1906. Notes on the distribution of the land and marine animals, with a list of the land plants and some remarks on the coral reefs. J. S. Gardiner: The Fauna and Geography of the Maldive and Laccadive Archipelagoes Cambridge: Cambridge University Press, 2,1046-1057.

Goodale, G. L. 1912. Biographical memoir of Alexander Agassiz 1835-1910. Biogr. Mem. Nat. Acad. Sci. 7, 291-305.

Gray, S. C. 1991. Late Quaternary history of reef growth, sea level, and diagenesis from three Cook Islands atolls. University of California at Santa Cruz, Ph.D. thesis. 208 pp.

Guppy, H. B. 1886. Notes on the characters and mode of formation of the coral reefs of the Solomon Islands. Proc. R. Soc. Edinb. 13, 857-904.

Hill, R. T. 1894. Notes on the Tertiary and later history of the island of Cuba. Am. J. Sci. (3) 48, 196212.

Hill, R. T. 1895. Notes on the geology of the island of Cuba. Bull. Mus. Comp. Zool. Harvard Coll. 16, 243-288.

Hill, R. T. 1899. The geology and physical geography of Jamaica. Bull. Mus. Comp. Zool. Harvard Coll. $34,1-256$.

Hoffmeister, J. E. and Ladd, H. S. 1935. The foundations of atolls: a discussion. J. Geol. 43, 653665.

Hoffmeister, J. E. and Ladd, H. S. 1944. The antecedent-platform theory. J.Geol. 52, 388-402.

Jukes, J. B. 1847. Narrative of the surveying voyage of H.M.S. Fly. London: T. and W. Boone. 2 vols.

Ladd, H. S. and Hoffmeister, J. E. 1936. A criticism of the glacial-control theory. J. Geol. 44, 74-92.

LeConte, J. 1856. On the agency of the Gulf-Stream in the formation of the Peninsula and Keys of Florida. Proc. Am. Assoc. Adv. Sci., 10 (2):103-119; also in Am. J. Sci. 2, 23:46-60.

LeConte, J. 1875. Rate of growth of corals. Am. J. Sci. 3, 10:34-36.

MacLeod, R. F.1988. Imperial reflections in the southern seas: the Funafuti Expeditions, 1896-1904. R. MacLeod and P. F. Rehbock (eds): Nature in its greatest extent: western science in the Pacific (Honolulu University of Hawaii Press), 159-191.

Maienschein, J. 1991. Collections and causes. Science 254, (5034), 1050-1052.

Mayer, A. G. 1910a. The Medusae of the World. Carnegie Instn. Washington Publ. 109, 1-735.

Mayer, A. G. 1910b. Alexander Agassiz, 1835-1910. Smithsonian Instn. Ann. Rept.1910, 447-472.

Mills, E. L. 1980. Alexander Agassiz, Carl Chun, and the problem of the intermediate fauna. M. Sears and D. Merriman, eds.: Oceanography: the past (New York: Springer), 360-372.

Montaggioni, L. F. and Pirazzoli, P. A. 1984. The significance of exposed coral conglomerates from French Polynesia (Pacific Ocean) as indicators of recent relative sea-level changes. Coral Reefs, 3, 29-42.

Murray, J. 1880. On the structure and origin of coral reefs and islands. Proc. R. Soc. Edinb. 10, 505-518. Murray, J. 1888. Coral formations. Nature 37, 414.

Murray, J. 1889. Structure, origin and distribution of coral reefs and islands. Proc. R. Instn.122, 251-262. 
Murray, J. 1911. Alexander Agassiz - his life and scientific work. Edinburgh University Library, Murray Papers, typescript, 36 pp. Also Science, 33 (1911), 873-887; Bull. Mus. Comp. Zool. Harvard Coll. $54(1911)$

Murray, J. and Irvine, R. 1889. On coral reefs and other carbonate of lime formations in modern seas. Proc. R. Soc. Edinb. 17, 79-109.

Newell, N. D. 1956. Geological reconnaissance of Raroia (Kon Tiki) Atoll, Tuamotu Archipelago. Bull. Am. Mus. Nat. Hist. 109, 311-372.

P[eattie], D. C. 1928. Agassiz, Alexander. Dict. Amer. Biog. 1, 111-114.

Pirazzoli, P. A.and Montaggioni, L. F. 1988. Holocene sea level changes in French Polynesia. Paleogeog. Paleoclimatol. Paleoecol. 68, 153-175.

Purdy, E. G. and Bertram, G. T.1991. Atoll and carbonate platform development in the Maldives, Indian Ocean. London: PetroQuest International. $73 \mathrm{pp}$.

Royal Society. 1904. The atoll of Funafuti: borings into a coral reef and the results. Being the Report of the Coral Reef Committee of the Royal Society. London: Royal Society. 428 pp.

Sawyer, B. and Andrews, E. C. 1901. Notes on the caves of Fiji, with special reference to Lau. Proc. Linn. Soc. N.S.W. 26, 91-106.

Semper, C. 1869. Die Philippinen und ihre Bewohner. Wurzburg.

Semper, C. 1873. Die Palau-Inseln im Stillen Ocean. Leipzig: Teubner. 672 pp.

Skeats, E. W. 1903. The chemical composition of limestones from upraised coral islands. Bull. Mus. Comp. Zool. Harvard Coll. 42, 51-126.

Stoddart, D. R. 1969. Reconnaissance geomorphology of Rangiroa Atoll, Tuamotu Archipelago, with list of vascular flora of Rangiroa by Marie-Helene Sachet. Atoll Res. Bull. 125, 1-44.

Stoddart, D. R. 1973. Coral reefs: the last two million years. Geography 58, 313-323.

Stoddart, D. R. 1975a. Almost-atoll of Aitutaki: geomorphology of reefs and islands. Atoll Res. Bull. 190, 31-57.

Stoddart, D. R. 1975b. Reef islands of Aitutaki. Atoll Res. Bull. 190, 59-72.

Stoddart, D. R. 1976. Darwin, Lyell, and the geological significance of coral reefs. Br. J. Hist. Sci. 9,199218.

Stoddart, D. R. 1988a. The duke, the professors, and the great coral reef controversy of 1887-1888. Earth Sci. Hist. 7; 90-98.

Stoddart, D. R. 1988b. Joseph Beete Jukes, the 'Cambridge connection', and the theory of reef development in Australia in the nineteenth century. Earth Sci. Hist. 7, 99-110.

Stoddart, D. R., Davies, P. S. and Keith, A. C. 1966. Geomorphology of Addu Atoll. Atoll Res. Bull. 116,13-41.

Stoddart, D. R., McLean, R. F., Scoffin, T. P., Thom, B. G. and Hopley, D. 1978. Evolution of reefs and islands, northern Great Barrier Reef: synthesis and interpretation. Phil.Trans. R. Soc. Lond. B 284, $149-159$.

Walcott, H. P. 1912. Alexander Agassiz. Proc. Am. Acad. Arts Sci. 48 (2), 31-44.

Winsor, M. P. 1991. Reading the shape of nature: comparative zoology at the Agassiz Museum. Chicago: University of Chicago Press. 324 pp.

Zinn, D. J. 1980. Alexander Agassiz (1835-1910) and the financial support of oceanography in the United States. M. Sears and D. Merriman, eds. Oceanography: The Past. New York: Springer. 